(1)

(16)

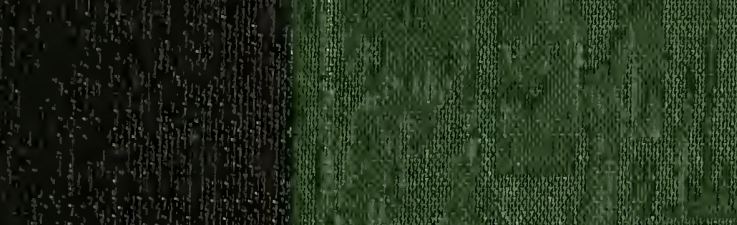

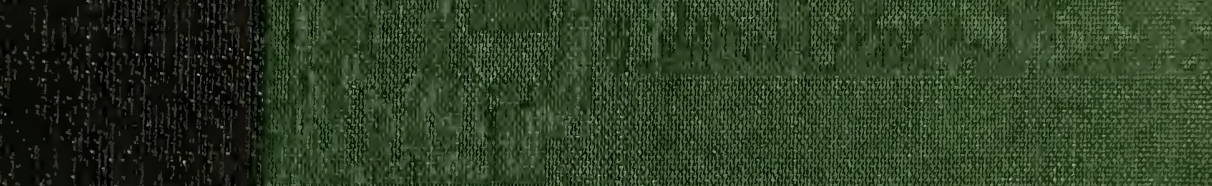

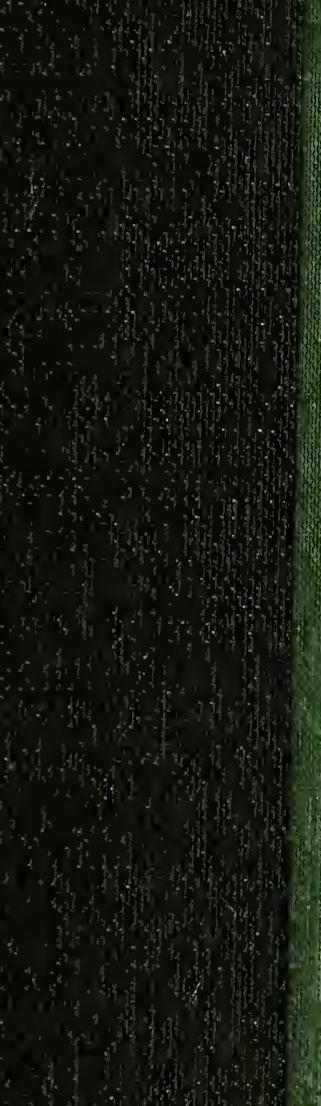

(4) 1.2. A.

(5)

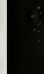

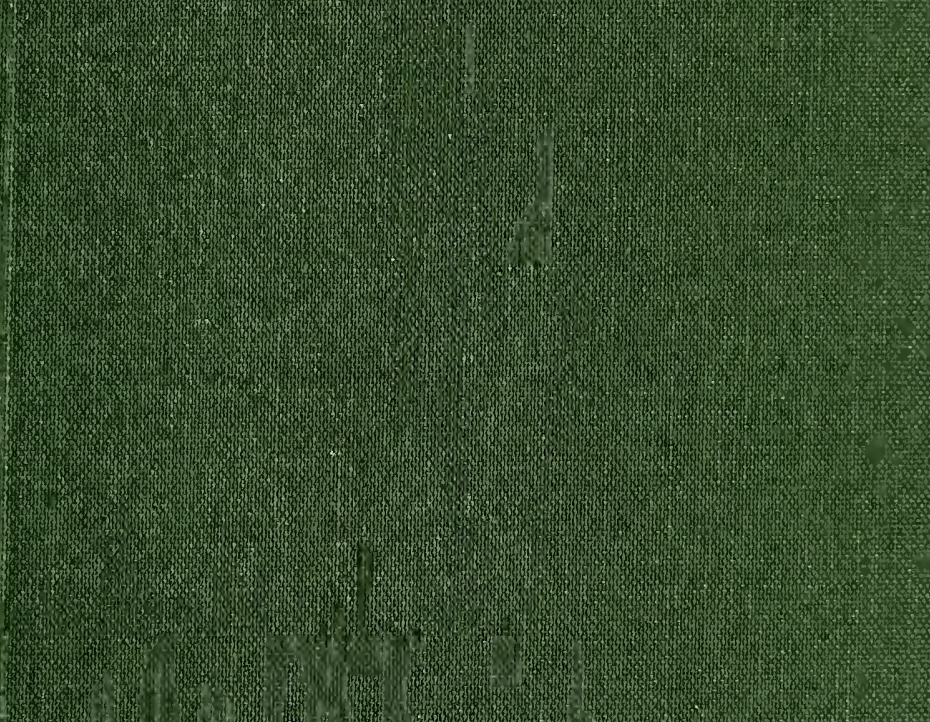
x-2.

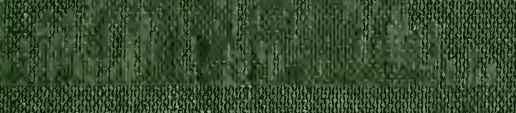

M

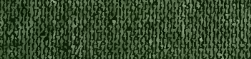

年

T.

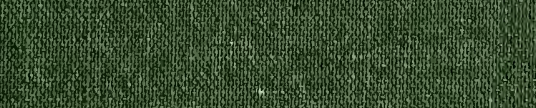

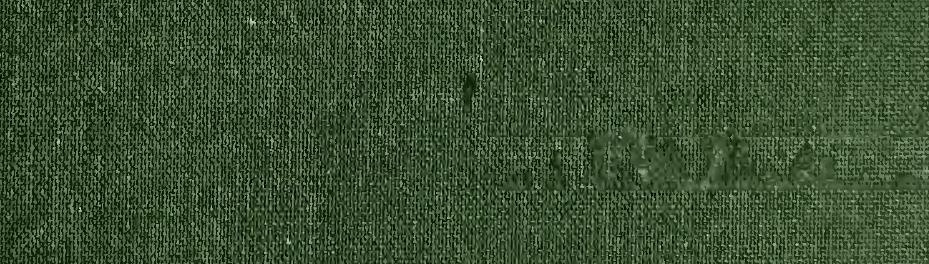









\section{The Atlanta University Publications, No. 14}

\section{EFFORTS FOR \\ SOCIAL BETTERMENT \\ AMONG}

NEGRO AMERICANS

A Social Study made by Atlanta University, under the patronage of the Trustees of the John F. Slater Fund

Price, 75 Cents 


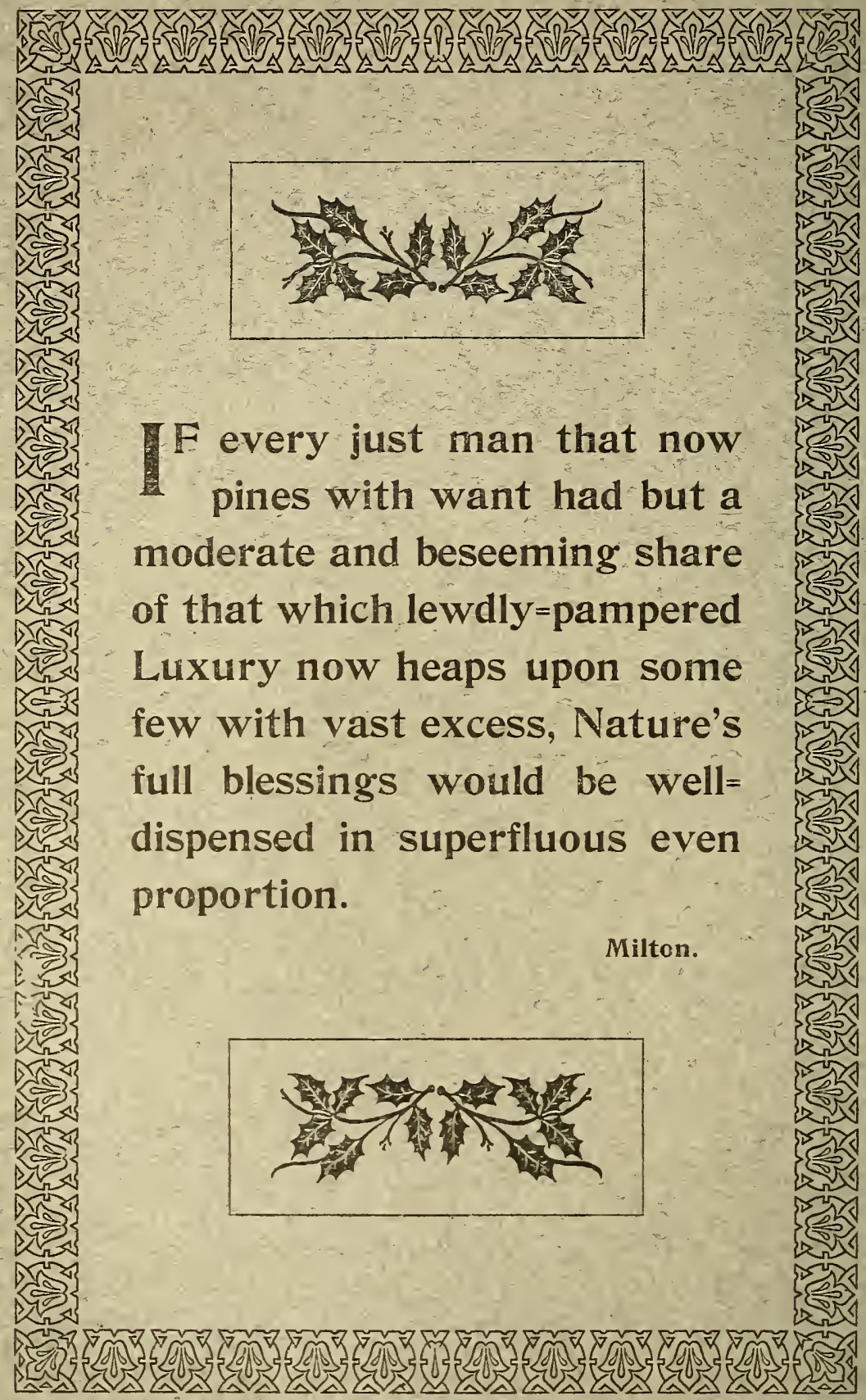






\section{The Atlanta University Publications, No. 14}

\section{Efforts for}

\section{Social Betterment}

\section{among}

\section{Negro Americans}

Report of a Social Study made by Atlanta University under the patronage of the Trustees of the John F. Slater Fund; together with the Proceedings of the 14th Annual Conference for the Study of the Negro Problems, held at Atlanta University on Tuesday, May the 24th, 1909

Edited by

W. E. Burghardt Du Bois

Corresponding Secretary of the Conference 

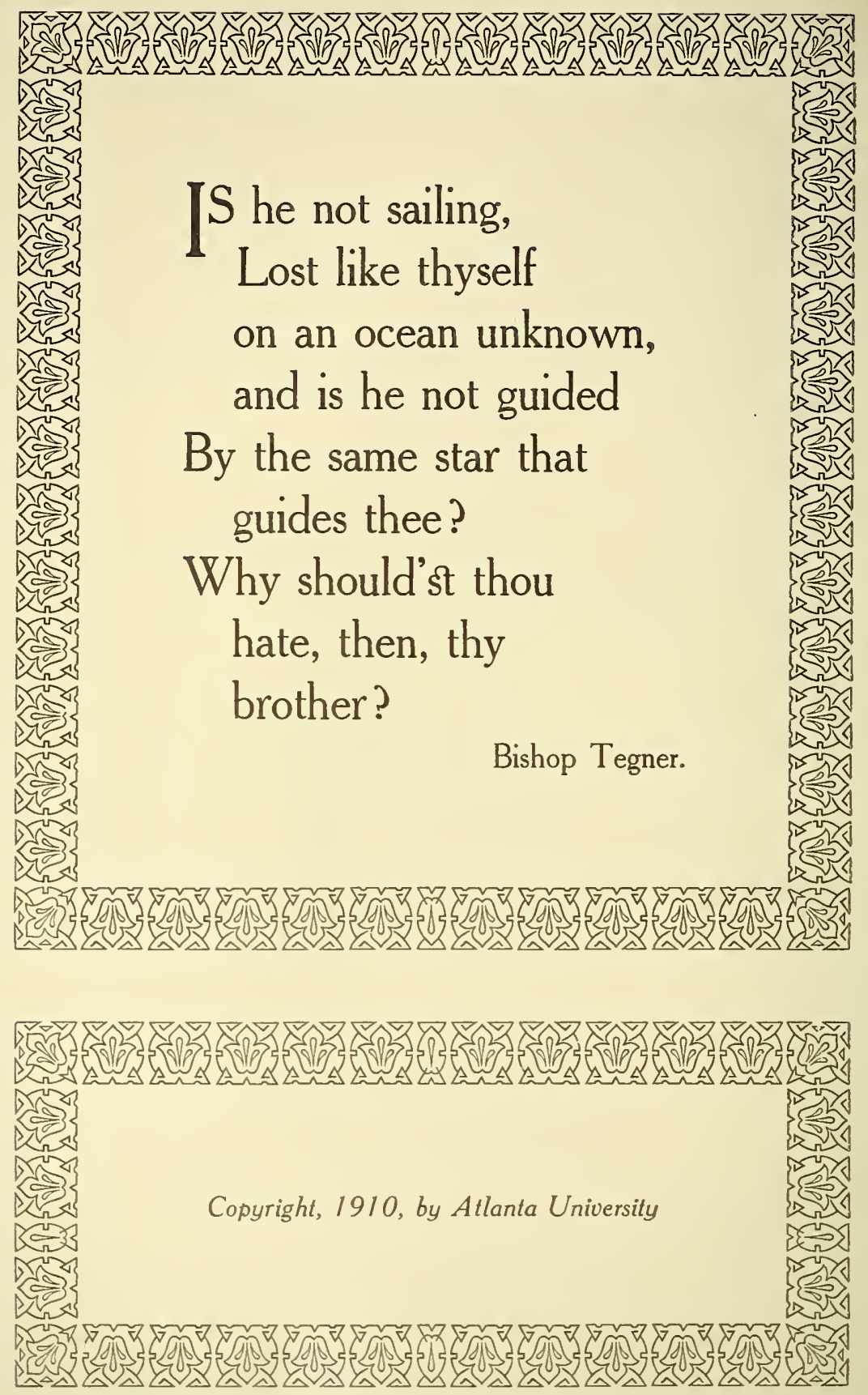


\section{Efforts for Social Betterment among Negro Americans}

\section{Contents}

Program of the Fourteenth Annual Conference PAGE Preface . . . . . . . . . . . . 5

Bibliography . • . . . . . . . . . . 7

1. Scope of the Inquiry . . . . . . . . . 9

2. The African Background . . . . . . . : 10

3. Slavery . . . . . . . . . . . 10

4. The Present Economic Basis . . . . . . . 12

5. The Church . . . . . . . . . . . 16

6. The School . . . . . . . . . . . 29

7. Miscellaneous General Efforts . . . . . . . 35

8. Negro Philanthropists . . . . . . . . . 37

9. General Charity . . . . . . . . . . 42

10. Women's Clubs . . . . . . . . . . 47

11. Old Folk's Homes . . . . . . . . . 65

12. Orphanages . . . . . . . . . . . 77

13. Hospitals . . . . . . . . . . 87

14. Y. M. C. Associations and Y. W. C. Assoriations . . . 95

15. Refuges and Homes for Women and Children . . . 100

16. Social, Literary and Art Clubs . . . . . . . 104

17. Iiterature and Newspapers . . . . . . . . 109

18. Libraries . . . . . . . . . . . . 117

19. Day Nurseries . . . . . . . . . . . 119

20. Social Settlements . . . . . . . . . . 121

21. Kindergartens . • . . . . . . . . . 126

22. Civic Reform . . . . . . . . . . 127

23. Miscellaneous . . . . . . . . . . . 130

24. Conclusion . . . . . . . . . . . 133

Index . . . . . . . . . . . . . . 134 


\section{The Fourteenth Annual Conference}

\section{Efforts for Social Betterment among Negro Americans}

\section{PROGRAMME}

First Session, 10:00 a. m.

President E. T. Ware presiding.

Subject: "Local Charities."

Address: Mr. William A. Rogers, 99, of the State Normal School, Petersburg, Ta.

Explanation of Charts: Dr. W. E. B. DuBois, Secretary of the Conference.

\section{Second Session, 11:30 a. $\mathrm{m}$.}

Subject: "Health and Social Betterment."

Special Talk to Men: Dr. Stephen A. Peters, '97 (Room 16).

Special Talk to Women: Miss Anna Knight, Medical Missionary in India (Chapel).

Third Session, 3:00 p. m.

Twelfth Annual Mothers' Meeting. (In charge of the Gate City Free Kindergarten.) Mrs. David T. Howard presiding.

Subiect: "The Children and Health."

1. Kindergarten songs, games and exercises by 150 children of the fire free kindergartens :

East Cain Street-Miss Ola Perry.

Bradley Street-Miss Hattie Sims.

Martin Street-Mrs. John Rush.

Dover Street-Miss Leila Golden.

Leonard Street-Miss Nannie Nichols.

2. Address: Miss Cornelia Bowen, president of the Alabama State Federation of Colored Women's Clubs.

3. Address: Mrs. J. W. E. Bowen.

4. Explanation of Kindergarten Exhibit-Miss Gertrude Ware.

5. Report of Treasurer: Mrs. Lizzie Burch.

6. Collection.

Fourth Session, 8:00 p. m.

President E. T. Ware presiding.

Subject: "Efforts for social Betterment."

Address: "Ihe Social Betterment of the Russian Peasant": Mr. I. M. Rubinow, Special Agent, Bureau of Labor, Washington. D. C., formerly of the Imperial Russian Ciril Service.

Stereopticon Exhibit of rarious current methods of Social Uplift.

\section{Errata}

On page 113 insert after "Dunbar, Paul Lawrence," and before "The Sport of the Gods":

Lyries of Lowly Life.

Lyrics of the Hearth Side.

Candle-lightin' time.

Lrrics of Love and Langhter.

Poems of Cabin and Field.
Folks from Dixie.

The Lncalled.

The Strength of Gideon.

The Lore of Landry.

The Fanatics. 


\section{Preface}

In 1898 the Atlanta University Negro Conference made an investigation into "Efforts of American Negroes for their own Social Betterment." As was explained in the report of that study: "To be of the highest value such an investigation should be exhaustive, covering the whole country and recording all species of effort. Funds were not available for such an inquiry. The method followed, therefore, was to choose nine Southern cities of varying size and to have selected in them such organizations of Negroes as were engaged in benevolent and reformatory work. The cities from which returns were obtained were: Washington, D. C., Petersburg, Va., Augusta, Ga., Atlanta, Ga., Mobile, Ala., Bowling Green, Ky., Clarkesville,Ten11., Fort Smith, Ark., and Galveston, Tex. Graduates of Atlanta University, Fisk University, Howard University, the Meharry Medical College, and other Negro institutions co-operated in gathering the information desired.

"No attempt was made to catalogue all charitable and reformatory efforts, but rather to illustrate the character of the work being done by typical examples. In one case, Petersburg, Va., nearly all efforts of all kinds were reported, in order to illustrate the full activity of one gromp. The report for one large city, Washington, was pretty full although not exhaustive. In all of the other localities only selected organizations were reported. The returns being for the most part direct and reduced to a basis of actual figures seem to be reliable."

Eleven years later the Atlanta Conference returns to the study of this subject, aided by an appropriation of $\$ 1,000$ from the Trustees of the John F. Slater Fund. It is, however, again not possible to make an exhaustive study of Social Betterment among the ten million people of Negro descent in the.United States. An attempt has been made, however, to secure in all parts of the country a fairly representative list of typical efforts and institutions, and the resulting picture while incomplete is nevertheless instructive.

'This study is, therefore, a further carrying out of the Atlanta University plan of social study of the Negro American, by means of an annual series of decennially recurring subjects covering, so far as is practicable, every phase of human life. The object of these studies is primarily scientific-a careful research for truth, conducted as thoroughly, broadly and honestly as the material resources and mental equipment at command will allow. It must be remembered that mathematical accuracy in these studies is impossible; the sources of information are of varying degrees of accuracy and the pictures are wofully incomplete. There is necessarily much repetition in the successive studies, and some contradiction of previous reports by later ones as new material comes to hand. All we claim is that the work is as thorough 
as circumstances permit and that with all its obvious limitations it is well worth the doing. Our object is not simply to serve Science. We wish not only to make the Truth clear but to present it in such shape as will encourage and help social reform.

Our financial resources are unfortunately meager: Atlanta University is primarily a school and most of its funds and energy go to teaching. It is, however, also a seat of learning and as such it has endeavored to advance knowledge, particularly in matters of racial contact and development, which seem obviously its nearest field. In this work it has received unusual encouragement from the scientific world, and the published results of these studies are used in America, Europe, Asia and Africa. Very few books on the Negro problem, or any phase of it, have been published in the last decade which have not acknowledged their indebtedness to our work.

On the other hand, the financial support given this work has been very small. The total cost of the fourteen publications has been about $\$ 16,000$, or a little over $\$ 1,000$ a year. The growing demands of the work, the vast field to be covered and the delicacy and equipment needed in such work, call for far greater resources. WV need, for workers, laboratory and publications, a fund of $\$ 6,000$ a year, if this work is going adequately to fulfill its promise. Two years ago a small temporary grant from the Carnegie Institution of Washington, D. C., greatly helped us, and for two years our work has been saved from suspension by an appropriation from the John F. Slater Fund.

In past years we have been enabled to serve the United States Bureau of Labor, the United States Census, the Board of Education of the English Government, many scientific associations, professors in nearly all the leading universities, and many periodicals and reviews. May we not hope in the future for such increased financial resources as will enable us to study adequately this the greatest group of social problems that ever faced America? 


\section{A Select Bibliography of Efforts for Social Betterment among Negro Americans}

\section{Books}

Annual Report of the Home Mission Board (Baptists). 14 reports.

Annual Report of the National Baptist Young People's Union Board. 10 reports.

Annual Reports of the Executive Board and Corresponding Secretary of the Woman's Convention Auxiliary to the National Baptist Convention. 9 reports. $1900(?)-1909$.

Annual Reports: Published by the various institutions noted within.

Atlanta Unirersity Publications:

No. 3. Some Efforts of Negroes for Social Betterment; $66 \mathrm{pp}$.

No. 6. The Negro Common School; 120 pp., 1901.

No. 8. The Negro Church; 212 pp., 1903.

No. 11. Health and Physique of the Negro American; $112 \mathrm{pp}$.

No. 12. Economic Co-operation among Negro Americans; 184 pp., 1907.

No. 13. The Negro American Family; 152 pp., 1908.

Arnett, Bishop B. B. The Budget. 7 vols. 1881, 1882, 1883, 1884, 1885-6, 1857-8, 1904.

Bruce, Roscoe Conkling. Service by the educated Negro. Tuskegee, 1903; 17 pp., $12 \mathrm{nu}$.

Cincinnati convention of colored freedmen of Ohio. Proceedings. January 14-19.1852. Cincinnati, 1852. 8 vo.

Clereland national emigration convention of colored people. Proceedings, August 22-24, 1854. Pittsburg, 1854. 8vo.

Cromwell, John W. The early Negro convention movement. Washington, 1904. (The American Negro Acad.) 23 pp., 8vo.

Delaware association for the moral improvement and education of the colored people. An. Reps., 1868, 1869, 1870. Wilmington, Del.

Eaton, J. Grant, Lincoln and the freemen. \$2.00. 1907. Longmans.

Freedmen, Annual reports of the Presbyterian Committee of Missions for 1871-1882. (Committee incorporated under the name of Presbyterian Board of Missions for Freedmen.) An. Reps., 1883-1909. Pittsburgh. 8ro.

Freedmen's Bureau:

Annual report of Adjutant-General's Branch of Freedmen for 1873-1877.

Annual report of Superintendent of North Carolina for 1864, 1867; of Louisiana for 1865; of Alabama for 1867; of the District of Columbia and West Virginia for 1867 .

Report of the General Superintendent of Freedmen. Department of the States of T'ennessee and Arkansas, for 1864-5.

Report of Commissioner of Bureau of refugees, freedmen, and abandoned lands, for $1865-1871$.

Report of the secretary of War for 1867, containing a synopsis of the report of the Commissioners of the Bureau of refugees, freedmen, and abandoned lands, for the same year.

Griggs, Sutton E. Imperium in imperio. Cincinnati, 1899 ; $265 \mathrm{pp}, 8 \mathrm{vo.}$

Helm, Mary. The Upward Path, the Evolution of a Race. New York, 1909. $333 \mathrm{pp}$.

Illinois State Convention of colored men. Proceedings at Galesburg, October 16, 17. 18. Chicago, 1867. $37 \mathrm{pp}, 8 \mathrm{vo}$.

Johnson, Edward A. Light ahead for the Negro. New York. 1904. 132 pp. '12mo.

Jones, C. C. The religious instruction of the Negroes in the United States. Savannah, 1842.277 pp. $12 \mathrm{mo.}$

Joyner, E. M. Missjons to the colored people in the South. Hartford, 1898. $18 \mathrm{pp.}$ $12 \mathrm{mo}$.

Leaflets, reports, etc., Woman's Home and Foreign Missionary Society, A. M. E. Z. Chureh.

Mayo, Amory Dwight. The opportunity and obligation of the educated class of the colored people in the Southern States. N.p. 1899(?). 32 pp. $8 v 0$.

Minutes of the first annual convention of the people of color. Philadelphia, 1831. Pamphlet. 
Minutes of the third annual convention of the free Negroes. Phila., 1833.

Minutes of the National Association of Colored Women's Clubs, 6 reports. 1897-1909.

National convention of colored men and their friends. Troy, N, Y., 1817. 38 pp. 8ro.

National con rention of colored men. Syracuse, N. Y., October 4-7, 1864 . Boston, 1864. $62 \mathrm{pp} .8 \mathrm{ro}$.

National convention of colored men of America. 1869. Proceedings. Washington, 1869. $42 \mathrm{pp}$. $8 \mathrm{ro}$.

Needles, Edward. 'Ten years' progress, or a comparison of the state and condition of the colored people in the city and county of Philadelphia from 1837 to 1847. Phila., 1849.

Negroes, Charities for. Home for destitute colored children, Marylandville, Pa. Annual reports, 1st-21st. Philadelphia, 1856-76. 2 rols. 8ro.

Negro young people's Christian and educational congress. Atlanta, 1902. The United Neglo. 600 pp. 8 ro.

Penn, Irvine Garland. The Afro-American press and its editors. Springfleld, 1891. 565 pp. $12 \mathrm{mo}$.

Proceedings of State Federations of Colored Women's Clubs. Texas, West Virginia, Iowa, Alabama, Colorado, Indiana, Kentucky, Maryland, Michigan, Minnesota, Georgia, Tennessee, Missouri, Ohio, Callfornia, Mississippi, Pennsylvania, Illinois, Florida, Virginia.

Quadrennial conference of the Women's Parent Mite Missionary Society of the A. M. E. Chureh. 4 reports.

Richings, G. F. Evidences of progress among colored people. 12th ed. \$1.00. 1905 . G. F. Richings, Ashland, Ohio.

Rudd, L. E. Catholic Afro-American congresses. Cincinnati, 1893.

Smith, Mrs. Amanda. Autobiography of Amanda Smith. Chicago, 1893.

\section{Periodicals}

Appeal for hospital endowment. 68:908. Outlook.

Atlanta Unicersity conference. W. E. B. DuBois. Charities.

Conference of Negroes at Tuskegee, Ala. 1892. R. U. Bedford. 8:251. Lend a Hand. Elevation of Tropical Races. B. Kidd. 57:545-50. Independent.

Ex-Governor Northen's work in Georgia. Independent. June 13, 1907.

Erolution of a Kentucky Negro Mission. L. J. Speed. Charities. September 21, 1907 Fresh air work among colored children in New York. M. W. Orington. Oharities. October 13, 1906.

Lifting of Negroes. G, Bradford. 39:162. Nation.

Negroes: What they are doing for themselres. S. J. Barrows. Atlantic. 67:805.

Negroes: how we can help them. C. A. Oliver. 42:85. Catholic World.

Negro Building and exhiblt at the Jamestown Exposition. 1907. H. A. Tucker Charities. September $21,1907$.

Negro's up-hill climb. R. R. Moton. Wordd's Work. April, May, August, 1907.

Progress a mong Negroes. E. P. Clark. 48:461. Nation.

Progress of the Negro in one county in the South. B. T. Washington. Outlook December 9,1905 .

Progress of the Negro. A. Walters. 53:651-2. Independent.

Race question solved in Buxton. G. L. MeNutt. Independent. May 30, 1807.

Savings of black Georgia. W. E. B. DuBois. 69:128-30. Outlook.

Settlement idea in the cotton belt. P. Dillingham. $70: 920-2$. Outlook.

Social condition of the Negro. H. L. Plillips. 9:575. Charities.

Training of Negroes for social porver. W. E. B. DuBois. 75-409-14. Outlook.

Village improvement among the Negroes. R. L. Smith. 64:733-6. Outlook.

Washington's colored population. S. C. Fernandis. Charities. September 14, 1907.

Washington's colored settlement. R. W. Buell. World To-day. August, 1906.

What the North and South have done for the Negro. 21 :606. DeBow's Review.

Washington, B. T. The Free Negro. Outlook. September 18, 1909.

Washington, B. T. Law and order and the Negro. Outlook. Norember 6, 1909.

Work, M. W. Self-help among the Negroes. Survey. Vol. 22, No. 9. 


\section{Efforts for Social Betterment among Negro Americans}

Section 1. Scope and Method of the Study. This monograph is an attempt to study efforts for social betterment among Negro Americans. By efforts for social betterment is meant nuainly benevolent efforts; i. e.. efforts not designed to secure direct economic return. Such activities as are usually called charitable and reformatory are the ones mainly noticed. The efforts noted are mainly those of colored people themselves directed toward their own social uplift, but some notice has also been taken of the charitable work of whites for Negroes and of the general charities of Negroes not confined to their race. The investigation was conducted as follows: In all the chief centers of Negro population the addresses of a number of persons of standing were obtained and the following letter sent them:

My dear Sir :

I want to get a list of all charitable institutions, clubs, or organizations of any kind conducted wholly or mainly by Negroes which are doing philanthropic work among colored people. I want to omit purely business enterprises, but to include everything that can reasonably be called an effort for social betterment. Will you kindly send me such a list for ........., so far as you know, and the addresses of persons who can give me further information?

I shall thank you very much.

To the addresses thus obtained was sent the following letter:

My dear Sir:

I am trying to get a list of all charitable institutions, clubs, or organizations of any kind conducted wholly or mainly by Negroes, which are doing philanthropic work among colored people. The name of the ......... has been handed me. I should like to know its history and all the material facts about this .........., together with a picture of the building and members, and also the figures sho,wing the growth and present activities, and amount of property owned. I shall thank you very much.

In this way a large number of reports were obtained, and sometimes several reports of the same club or institution. For the most part, however, the only proof of the work reported was: (a) the word of a reliable resident that the institution existed and was doing some work of the kind indicated; (b) the report of the directors of the work. There is hele room for some exaggeration and coloring. Some of the institutions reported may go out of existence before the report is in print and others may be started. The report is not complete or exhaustive in any sense of the word. It does; however, cover most of the larger efforts and many of the more typical ones and some of the minor ones. 
Section 2. The African Background. If there is one thing in which the life of barbarians shows a decided superiority to that of civilized people it is in its solution of the problem of poverty. Under tribal communism no individual can be poorer than the tribe. This, to be sure, makes all suffer for the laziness of a few and to a degree penalizes individual thrift. It is doubtful, however, if this explains altogether the lack of accumulated wealth. At any rate it is no little thing to avoid the fearful paradox of modern life-abounding wealth and stinging poverty in the same group, with the necessity of personal charity to ward off the extremes of death and suffering. Of charity, as such, there was no need among Africans, since all shared the common fund of land and food. In the care of the old and young there was a chance for benevolence. The young were adopted by law, into the brother's family if the fathor died, into the care of another wife of the father if the mother died. The old did not fare so well. If the tribe was nomadic they were killed to keep them from falling into the hands of the enemy or from baser motives. Gradually the permanently st ttled tribes began to hold their elders in more veneration and look up to then for advice and tradition. Oucside of these fundamental matters there was nothing in African life corresponding to modern benevolence.

Section 3. Slavery. No generalization is safe touching the condition of slaves in America. The plantations were self-sufficient oligarchies or monarchies, little interfered with by State or municipal law. On some of them there was severe child labor, no care in sickness, and neglect or' sale of the old. On other plantations the children were well cared for, the sick nursed and the old protected. Two abstracts will illustrate these things. Frances Kemble writes:

The Infirmary is a large two-story building, terminating the broad orangeplanted space between the two rows of houses which form the first settlement; it is built of whitewashed wood, and contains four large-sized rooms. But how shall I describe to you the spectacle which was presented to me on entering the first of these? But half the casements, of which there were six, were glazed and these were obscured with dirt, almost as much as the other windowless ones were darkened by the dingy shutters, which the shivering inmates had fastened to in order to protect themselves from the cold. In the enormous chimney glimmered the powerless embers of a few sticks of wood, round which, however, as many of the sick women as could approach were cowering, some on wooden settles, most of them on the ground, excluding those who were too ill to rise; and these last poor wretches lay prostrate on the floor, without bed, mattress, or pillow, buried in tattered and filthy blankets, which, huddled round them as they lay strewed about. left hardly space to more upon the floor. And here, in their hour of sickness and suffering, lay those whose health and strength are spent in unrequited labor for us-those who, perhaps even yesterday, were being urged on to their unpaid task-those whose husbands, fathers, brothers and sons were even at that hour sweating over the earth, whose produce was to buy for us all the luxuries which health ean revel in, all the comforts which can alleviate sickness. I stood in the midst of them, perfectly unable to 
speak, the tears pouring from my eyes at this sad spectacle of their misery, myself and my emotion alike strange and incomprehensible to them. Here lay women expecting every hour the terrors and agonies of childbirth, others who had just brought their doomed offspring in to the world, others who were groaning orer the anguish and bitter disappointment of miscarriages-here lay some burning with fever, others chilled with cold and aching with rheumatism, upon the hard cold ground, the draughts and dampness of the atmosphere increasing their sufferings, and dirt, noise and stench, and every aggraration of which sickness is capable, combined in their condition-here they lay like brute beasts, absorbed in physical suffering; unvisited by any of those Divine influences which may ennoble the dispensations of pain and illness, forsaken, as it seemed to me, of all good; and yet, o God, Thou surely badst not forsaken them! Now pray take notice that this is the hospital of an estate where the owners are supposed to be humane, the overseer efficient and kind, and the negroes remarkably well cared for and comfortable.

On the other hand Byron Tyson declares:

"Thus, of the three stages, youth, maturity, and old age, through which the servants pass, there is but one in which they are relied on as regular laborers. In childhood and in old age they are well taken care of, and thus the whole slave population is rendered self-supporting. So, of the $3,953,760$ slaves that were in the United States in 1860 , there was not one supported by a public tax. Such an instance, I presume, is unknown among an equal number of the industrial classes, anywhere in the civilized world. I will ask where else on the face of the globe culd you go to find, in a population of nearly four millions, no paupers? 1

That slaves were often neglected is shown by laws like the following law of Georgia :

"Section 1. From and after the passing of this act (December 12, 1815), it shall be the duty of the inferior courts of the several counties in this State, on receiving information, on oath, of any inflrm slave or slaves being in a suffering situation, from the neglect of the owner or owners of such slave or slares, to make particular inquiries into the situation of such slave or slaves, and render such relief as they in their discretion may think proper.

"Section 2 The said courts may, and they are'hereby authorized, to sue for and recover from the owner or owners of such slave or slaves, the amount that may be appropriated for the relief of such slave or slaves, in any court having jurisdiction of the same; any law, usage or custom to the contrary notwithstanding."-Prince's Digest, 460.

Relief of suffering among slaves depended entirely on the character of the masters. That there was a great deal of relief work there can be no doubt. Indeed, the habit of direct relief to Negroes which thus grew up in slavery is now a great hindrance to organized and scientific charity in the South. Among the slaves the charitable work was chiefly in the line of adopting children and caring for the sick. The habit of adoption is still wide-spread and beneficent.

\footnotetext{
1 Pamphlet on the Institution of Slavery, etc., by Byron Tyson, p. 8-9.
} 
Section 4. The Present Economic Basis. How far is the Negro American to-day economically able to maintain a systeln of charitable relief for his own people? We can perhaps best realize these conditions by picturing a single community: Jacksonville, Florida, for instance, had 16,000 Negroes in 1900 . To-day it has nine colored lawyers, eighteen colored physicians, ten colored drug stores, two sanitariums, one bank, one livery sale and feed stable, two garages, ten real estate dealers, three undertaking establishments, three denominational schools and a school for girls only, one old folks' hoine, one orphanage, one industrial school, one institutional church which operates a sewing class, dressmaking, bookkeeping, kindergarten, cooking, gymnasium, music-instrumental and vocal; has two paid missionaries, an assistant pastor. The church owns a full city block in the heart of the eity, valued at $\$ 125,000$. There are two dentists, a colored board of trade, the first and only one in the South; three cigar factories, three wholesale fish and poultry dealers; four hotels, containing twenty-five to one hundred rooms each; three weekly newspapers; one Odd Fellows Temple, valued at $\$ 100,000$, and one K. of P. Temple, both paid for; several Masonic Temples of less value; one large jewelry store; one curio store; ten public school buildings; twenty-six letter carriers and postal clerks; three deputy collectors of customs; numbers of railway mail clerks; one shoe store; two ind ustrial insurance companies that own their buildings, one valued at $\$ 35,000$.

To this may be added the following general facts: a committee of the American Economic Association reported:

The evidence in hand leads your committee to the conclusion that the accumulated wealth of the Negro race in the United States in 1900 was approximately $\$ 300,000,000$, and probably neither less than $\$ 250,000,000$ nor more than $\$ 350,000,000$.

Since 1900 the increase of Negro property holdings has been very rapid, as the records in three States show:

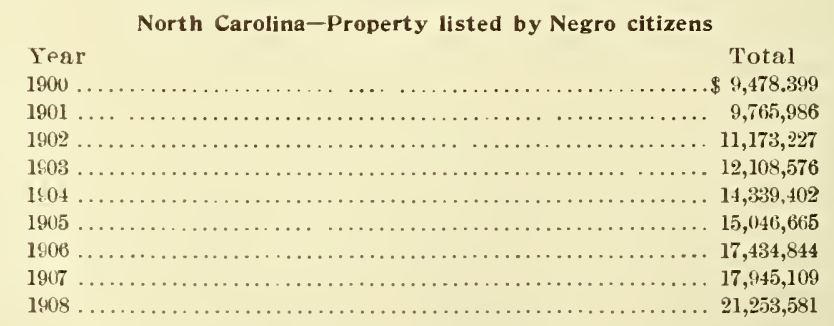

Total Value of Real Estate and Personal Property Owned by Negroes in Virginia 1891

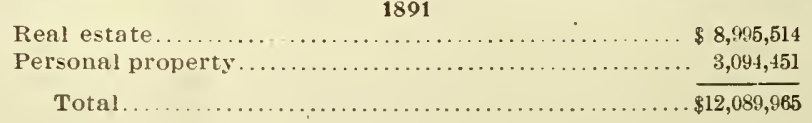


1900

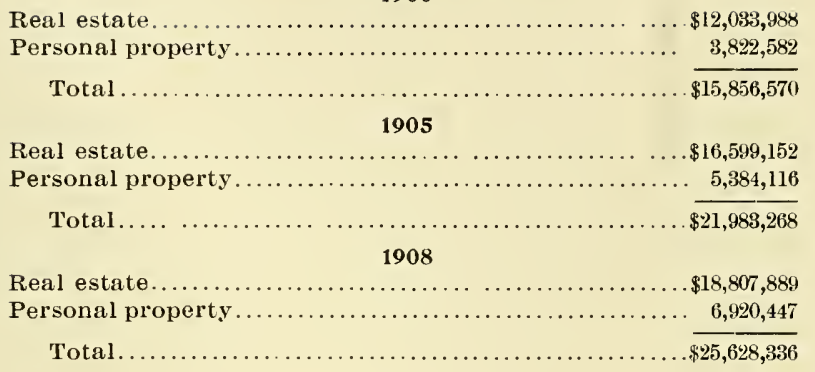

Total Assessed Wealth of Georgia Negroes

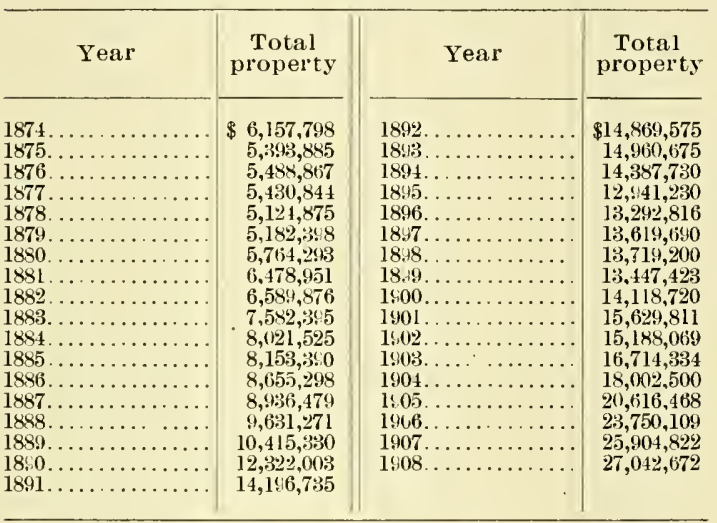

Property per Capita for Georgia Negroes

\begin{tabular}{|c|c|c|c|}
\hline Year & $\begin{array}{c}\text { Property } \\
\text { per capita }\end{array}$ & Year & $\begin{array}{l}\text { Property } \\
\text { per capita }\end{array}$ \\
\hline 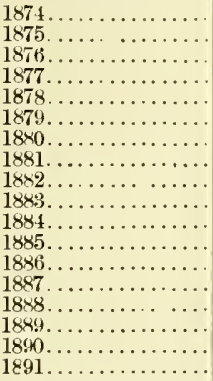 & $\begin{array}{r}\$ 9.98 \\
8.49 \\
8.44 \\
8.09 \\
7.44 \\
7.33 \\
7.95 \\
8.77 \\
8.77 \\
9.91 \\
10.30 \\
10.21 \\
10.75 \\
10.92 \\
11.57 \\
12.32 \\
14.35 \\
16.20\end{array}$ & 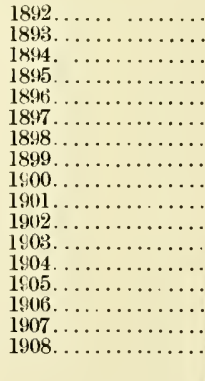 & $\begin{array}{l}\$ 16.63 \\
16.41 \\
15.48 \\
13.67 \\
13.78 \\
13.87 \\
13.72 \\
13.24 \\
13.64 \\
14.85 \\
11.19 \\
15.37 \\
16.28 \\
18.37 \\
20.82 \\
22.37 \\
23.003\end{array}$ \\
\hline
\end{tabular}




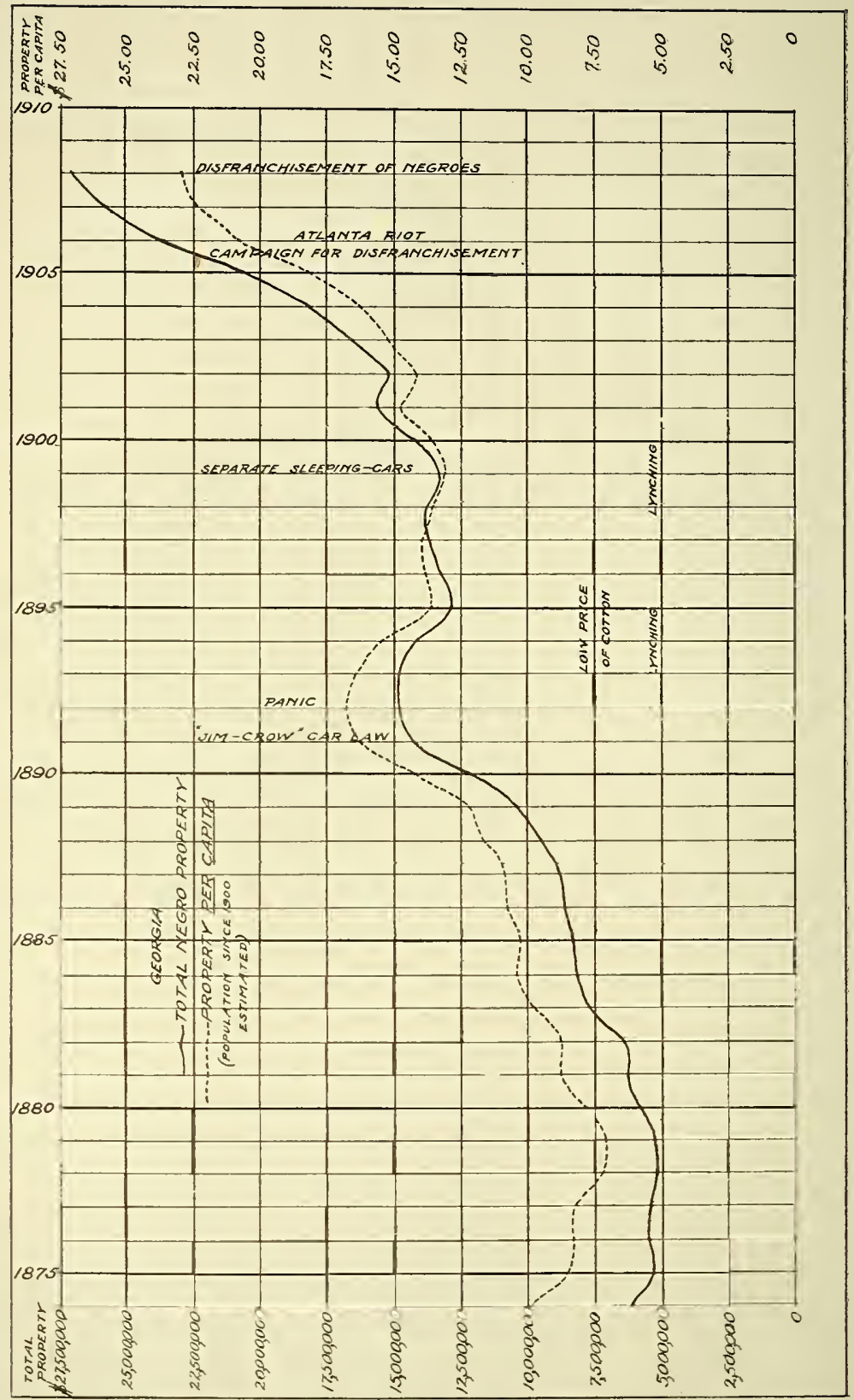




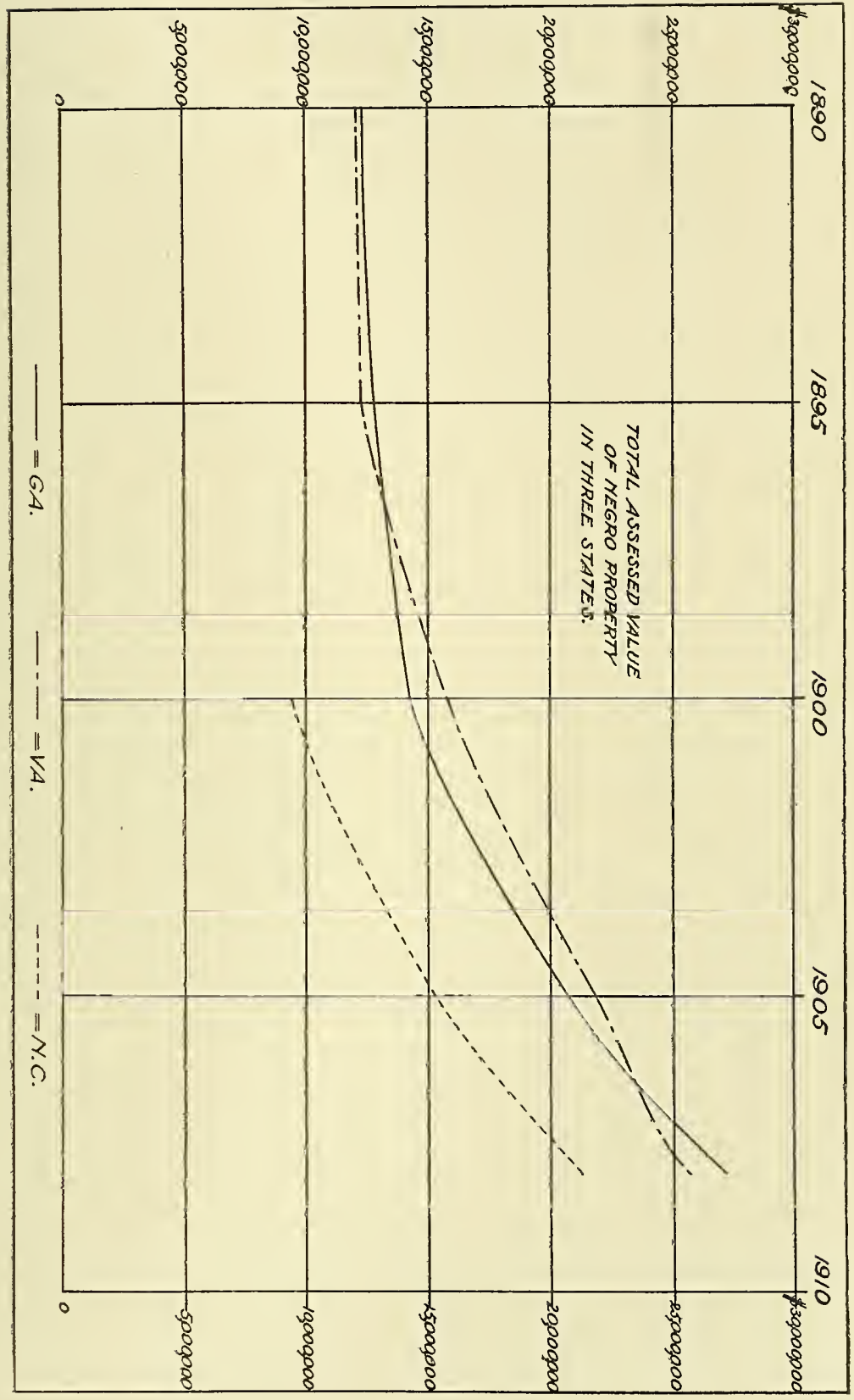


From these figures we may deduce this simpler table:

Assessed Value of Property

\begin{tabular}{|c|c|c|}
\hline & 1600 & 1908 \\
\hline Georgia ......... & $\$ 14,118,720$ & $\$ 27,042,672$ \\
\hline Virginia ......... & $15,856,570$ & $25,628,336$ \\
\hline North Carolina. & $9,478,399$ & $21,253,581$ \\
\hline Total ........ & $\$ 39,453,689$ & $\$ 73,924,589$ \\
\hline
\end{tabular}

Actual increase, $\$ 34,470, \$ 00$

Increase per cent., $8 \% 1 / 3$.

Judging from these figures and the report of the American Economic Association quoted above it would seem fair to infer that the total property of Negro Americans aggregated $\$ 560,000,000$ in 1908 .

Section 5. The Church. As was said in the study of 1898: It is natural that to-day the bulk of organized efforts of Negroes in any direction should center in the Church. "The Negro Church is the only social institution of the Negroes which started in the forest and survived slavery; under the leadership of the priest and medicine man, afterward of the Christian pastor, the Church preserved in itself the remnants of African tribal life and became after emancipation the center of Negro social life. So that to-day the Negro population of the United States is virtually divided into Church congregations, which are the real units of the race life. It is natural, thelefore, that charitable and rescue work among Negroes should first be found in the chmrches and reach there its greatest development."

The statistics for Negro churches in 1906 according to the United States Census was as follows: "The total number of communicants or members, as reported by 36,563 organizations, is $3,685,097$; of these, as shown by the returns for 34,618 organizations, 37.5 per cent are males and 62.5 per cent females."

According to the statistics, these organizations have 35,160 church edifices; a seating capacity for church edifices of $10,481,738$, as reported by 33,091 organizations; church property valued at $\$ 56,636.159$, against which there appears an indebtedness of $\$ 5,005,905$; halls, etc., used for worship by 1.261 organizations; and parsonages valued at $\$ 3,727,884$. The number of Sunday-shools, as reported by 33,538 organizations, is 34,681 , with 210,148 officers and teachers and $1,740,099$ scholars.

As compared with the report for 1890 , these figures show increases of 13.308 in the number of colored organizations, $1,011,120$ in the number of communicants or members, 11,390 in the number of church edifices and $\$ 30,009,711$ in the value of church property. 
The Church
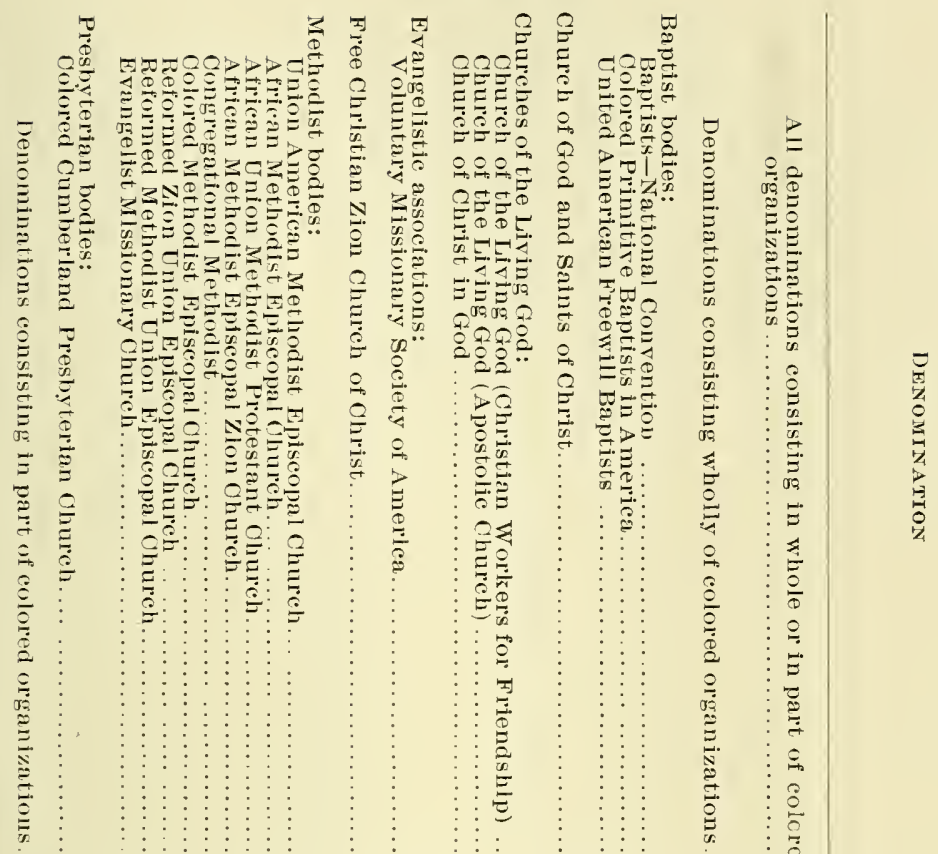

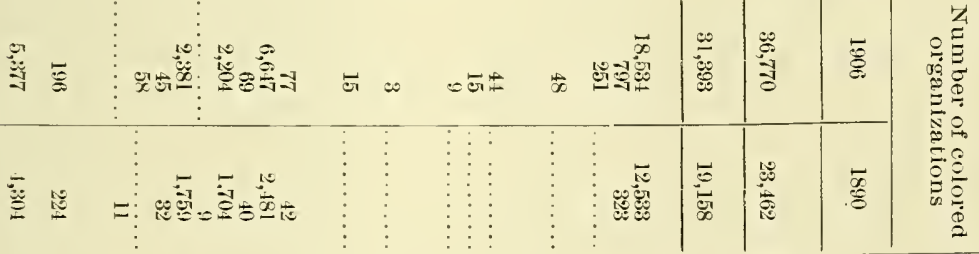

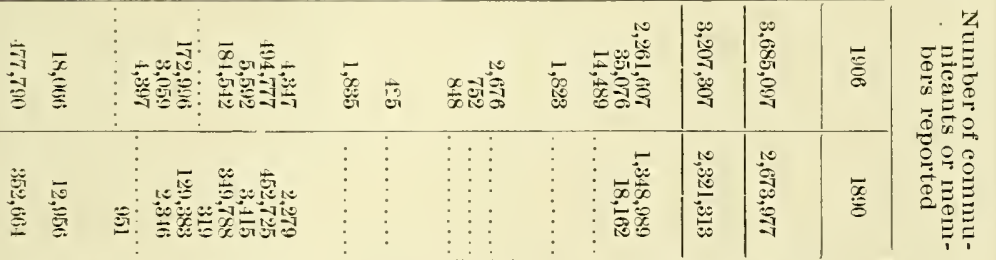

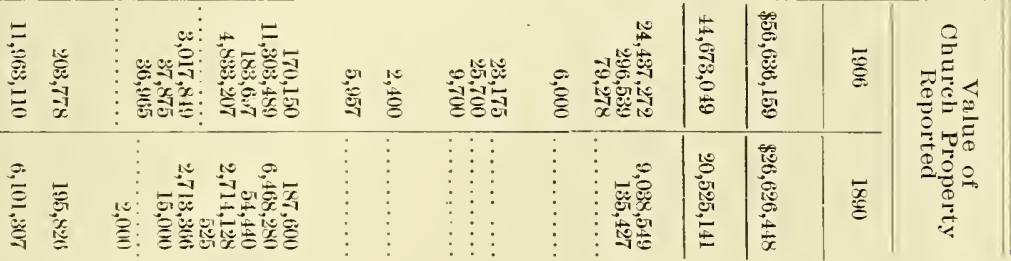


It was estimated in 1907 that these churches raised seven and a half million dollars a year. Most of the half million goes probably to pay high interest on a debt of five millions. The remaining seven millions goes chiefly to the support of the pastor, the maintenance of the plant and general church purposes. A large and growing share, however, goes to "mission" work. Part of this is proselyting, but the larger part of it is distinctly benevolence and work for social betterment. No complete record of this work can be obtained. Outside of these money contributions by far the larger part of the benevolent work of Negroes is the unorganized personal work of church members among the congregations. This consists of donations, visits, care of the sick, adoption of children, etc.

The missionary money raised by the churches is shown by the following figures:

A. M. E. Missionary Dept.-Total collection, April 23, 1904, to A pril 4, 1908, inclusive

\begin{tabular}{|c|c|c|c|c|c|}
\hline & 1905 & 1906 & 1907 & 1908 & Total \\
\hline $\begin{array}{l}\text { Easter Collections: } \\
\text { Receired by Missionary Depart- } \\
\text { ment, } 75 \text { per cent.............. } \\
\text { Receised and disbuised by Con- } \\
\text { ferences, } 25 \text { per cent............ }\end{array}$ & $\begin{array}{r}\$ 13,020.41 \\
4,340.14 \\
\end{array}$ & $\begin{array}{r}\$ 18,310.00 \\
6,103.33 \\
\end{array}$ & $\begin{array}{r}\$ 15,310.27 \\
5,113.42 \\
\end{array}$ & $\begin{array}{r}\$ 1,922 .(i 1 \\
1,640.87\end{array}$ & \multirow{4}{*}{$\$ 68,791.05$} \\
\hline Total Easter Collections, 4 years & $\$ 17,360.55$ & $\$ 24,413.33$ & $\$ 20,453.69$ & $\$ 5,563.48$ & \\
\hline 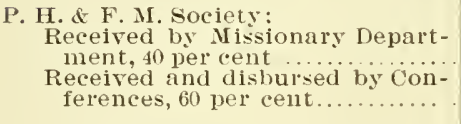 & $\begin{array}{r}\$ 1,464.15 \\
2,196.18\end{array}$ & $\begin{array}{r}\$ 1,762.05 \\
2,643.06 \\
\end{array}$ & $\begin{array}{r}\$ 1,943,03 \\
2,914.56\end{array}$ & $\begin{array}{r}\$ 2,224.15 \\
3,336.24\end{array}$ & \\
\hline $\begin{array}{l}\text { Total P. H. \& F. M. Society Col- } \\
\text { lections, } 4 \text { years................. }\end{array}$ & $\begin{array}{l}\$ 3,660.33 \\
\ldots \ldots \ldots\end{array}$ & $\$ 4,40 \overline{.11}$ & $\begin{array}{l}\$ 4,557.59 \\
\ldots \ldots \ldots\end{array}$ & \$\$ $5,560.39$ & \\
\hline $\begin{array}{l}\text { W. H. E F. M. Society: } \\
\text { Received by Missionary lepart- } \\
\text { ment, } 50 \text { per cent } \\
\text { Received and disbursed by con- } \\
\text { ferences, } 50 \text { per cent............. }\end{array}$ & $\begin{array}{l}\$ \quad 57 \% .67 \\
\$ \quad 573.67\end{array}$ & $\begin{array}{l}\$ 1,101.40 \\
\$ 1,101.40\end{array}$ & $\begin{array}{l}\$ 1,292.23 \\
\$ 1,292.23\end{array}$ & $\begin{array}{l}\$ 1,931.35 \\
\$ 1,931.35\end{array}$ & \multirow{3}{*}{$\$ 9,797.80$} \\
\hline \multirow[t]{2}{*}{$\begin{array}{l}\text { Total W. H. \& F. M. Society col- } \\
\text { lections, } 4 \text { years................. }\end{array}$} & $\$ 1,147.34$ & $\$ 2,202.80$ & $2,584.46$ & $\$ 3,862.70$ & \\
\hline & $1903-1904$ & $1904-1905$ & $1905-1906$ & $1906-1507$ & \\
\hline 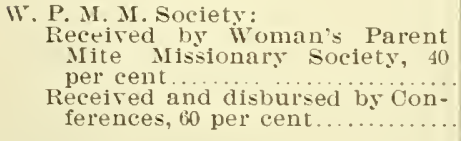 & $\$ 2,016.91$ & $\$ 1,97 \cdot 2.13$ & $\$ 3,202.24$ & $\begin{array}{r}\$ 3,194.31 \\
4,791.43\end{array}$ & \\
\hline $\begin{array}{l}\text { Woman's Parent Mite Missionary } \\
\text { Soctety, } 4 \text { years ................... }\end{array}$ & $\$ 5,042.2 !$ & $\$ 4,430.31$ & $\$ 8,005.60$ & $\$ 7,985.74$ & $\$ 25.963 .94$ \\
\hline 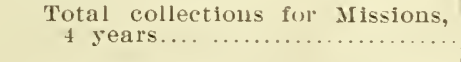 & & & & & $\$ 123,035.71$ \\
\hline
\end{tabular}


The Church

A. M. E. Church, 1864=1903

Home and Foreign Missionary Department

\begin{tabular}{|c|c|c|c|}
\hline & Raised & $\begin{array}{l}\text { Recevved from } \\
\text { dollar money }\end{array}$ & $\begin{array}{c}\text { Total } \\
\text { expended }\end{array}$ \\
\hline $\begin{array}{l}1864-1868 \ldots \ldots \\
1865-1872 \ldots \ldots \\
1872-1880 \ldots \ldots \\
1880-1881 \ldots \ldots \\
1881-1888 \ldots \ldots \\
1888-1892 \ldots \ldots \\
1892-1896 \ldots \ldots \\
1896-1900 \ldots \ldots \\
1900-1903 \ldots \ldots\end{array}$ & $\begin{array}{r}\$ 5,42565 \\
9,317.32 \\
12,504.22 \\
34,811.83 \\
19,001.09 \\
25,675.47 \\
66,819.27 \\
58,876.36 \\
80,815.66\end{array}$ & $\begin{array}{c}\ldots \ldots \ldots \ldots \cdots \\
\$ \ldots \ldots \\
27,913.56 \\
54,510.51 \\
73,227.18 \\
187,772.15 \\
146,050.24 \\
145,226.71 \\
136,805.15\end{array}$ & $\begin{array}{r}5,425.65 \\
9,317.32 \\
40,417.78 \\
89,322.34 \\
92,228.27 \\
213,447.42 \\
21 \cdot, 869,51 \\
214,103.07 \\
217,620.81\end{array}$ \\
\hline Total.... & $\$ 313,216.87$ & $\$ 771,505.80$ & $\$ 1,(181,752.67$ \\
\hline
\end{tabular}

Seven per cent of the income of the African Methodists goes for missionary and charitable purposes. If this is true of all Negro church bodies, then their expenditure for such purposes is over half a million a year. The expenditures of the Baptists are reported as follows :

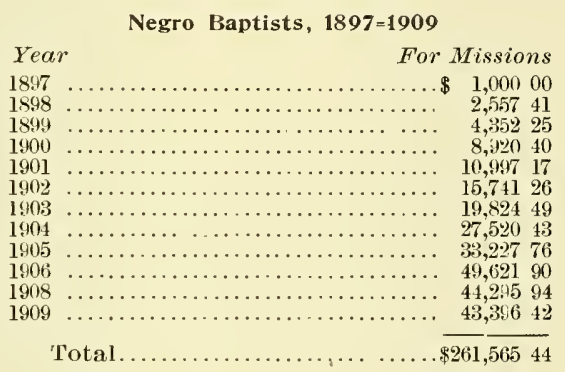

The figures for Negro Baptist foreign mission work for 1907 were:

Summary by Months

\begin{tabular}{|c|c|}
\hline $\begin{array}{l}\text { September } \ldots \ldots \ldots \ldots \\
\text { Oetober } . . . \ldots \ldots \ldots\end{array}$ & $\begin{array}{r}1,85350 \\
63410\end{array}$ \\
\hline November... & 3,01477 \\
\hline December ............................ & $553 \quad 37$ \\
\hline January $\ldots \ldots \ldots \ldots \ldots \ldots \ldots \ldots \ldots$ & 63474 \\
\hline February... & $1,58,78$ \\
\hline March ..... & 43679 \\
\hline April..................... & $4,197 \quad 69$ \\
\hline 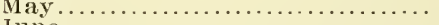 & 1,67173 \\
\hline June $\ldots \ldots \ldots \ldots \ldots \ldots \ldots$ & 73626 \\
\hline July ....................... & 1,15133 \\
\hline & 2,27360 \\
\hline
\end{tabular}

The report of activities for 1908 and 1909 follows: 


\begin{tabular}{|c|c|c|}
\hline & 1908 & 1909 \\
\hline 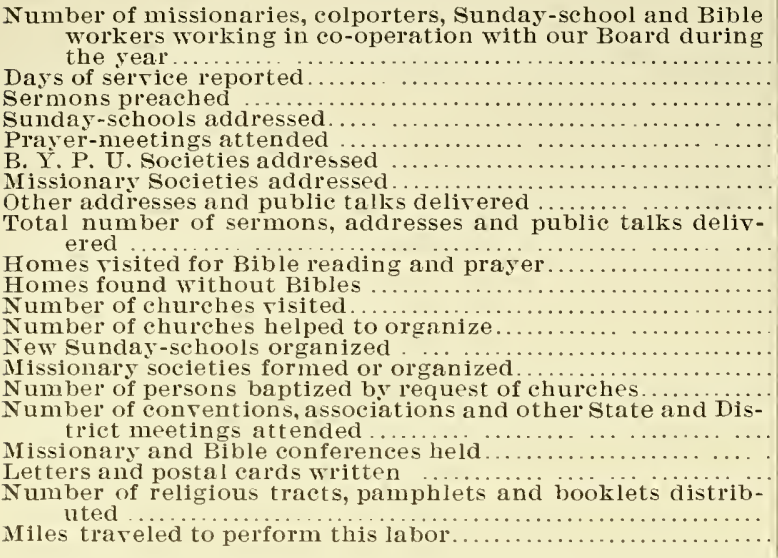 & $\begin{array}{r}43 \\
8,678 \\
3,582 \\
1,345 \\
2,369 \\
395 \\
397 \\
2,141 \\
10,229 \\
5,853 \\
507 \\
3,221 \\
38 \\
42 \\
58 \\
1,260 \\
1,970 \\
1,970 \\
10,265 \\
19,569 \\
157,363\end{array}$ & $\begin{array}{r}65 \\
3.812 \\
3.702 \\
1,441 \\
2,765 \\
563 \\
481 \\
2,859 \\
9,046 \\
9,410 \\
1,788 \\
4,755 \\
21 \\
39 \\
37 \\
841 \\
1,542 \\
1,547 \\
14,847 \\
18,569 \\
270,639\end{array}$ \\
\hline & 1908 & 1909 \\
\hline 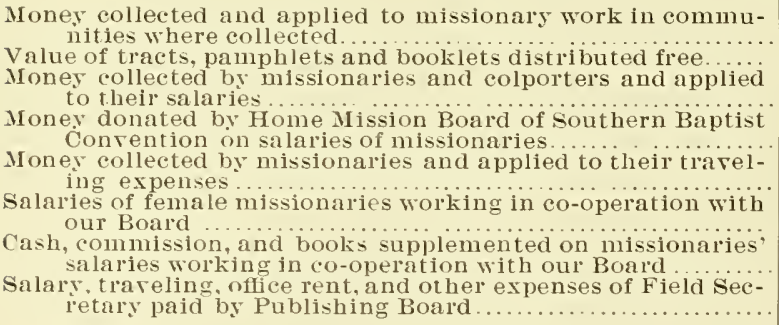 & $\begin{array}{r}\$ 14,68611 \\
585 \\
46 \\
5,52157 \\
7,26250 \\
3,076 \quad 34 \\
98000 \\
9,78396 \\
2,400 \quad 00\end{array}$ & $\begin{array}{r}\$ 16,02724 \\
59946 \\
5,93737 \\
9,25000 \\
5,082 \quad 35 \\
95000 \\
3,85000 \\
1,700 \quad 00\end{array}$ \\
\hline Total. & $\$ 44,29594$ & $\$ 43,396 \quad 42$ \\
\hline
\end{tabular}

"The Home Mission Board, in its general organization, is made up of fiftythree members appointed from the same number of State and Territorial conrentions by your body. We have a general organization. This organization holds annually two sessions when at the sitting of the convention, for the reason that it is a financial impossibility to bring these members from the various parts of the L'nited states and its insular possessions oftener than once a rear. Howerer, we, by the provision of the Constitution, have an Executive Board of the National Baptist Publishing Board, located at Nashrille, Tenn. We co-operate with them both in the employment of a missionary or corresponding secretary, and in performing missionary work; by this method we areattempting to economize as much as possible, and use all the available means on purelr missionary work. This method of operation has proven beneficial to the field and satisfactory to both boards." 
One of the agencies of uplift among the Baptists is the Baptist Young' People's Union. The department has in ten years accomplished the following work:

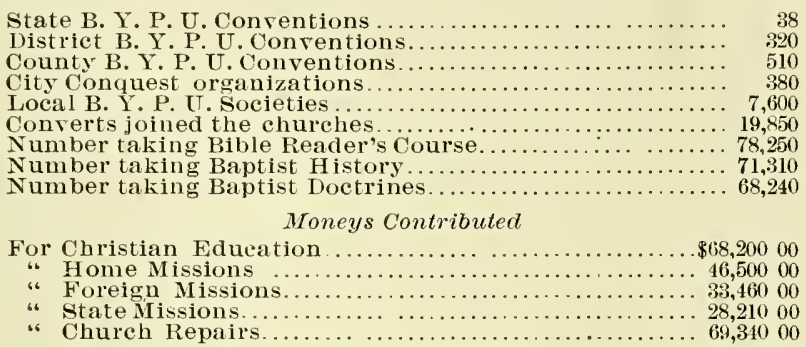

Most of the local benevolence of Baptist churches is not reported and can be ascertained only in local associations. For instance, a West Virginia association (New River Valley) reports, July, 1908:

Fifty-eight churches gave in one year for:

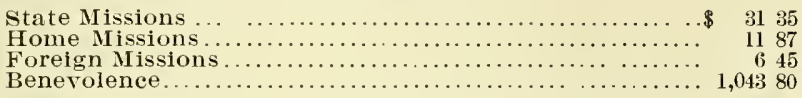

The Baptist convention of the State of Texas reported under church support in 1903: Five schools, a chautauqua, an orphanage and an "Old Folk's" home.

The convention has raised the following sums of money:

\section{State Mission Money}

Raised by the Baptist Missionary and Edueational Convention, commencing with the year 1883 :

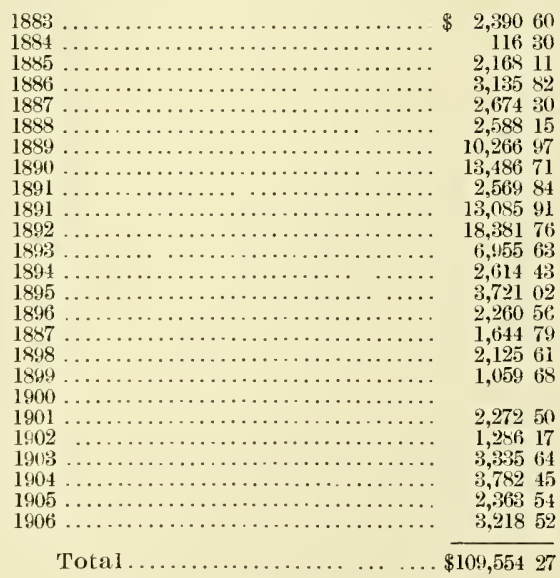

Most of this money was raised among Negroes, but there were some contributions from whites. From Arkansas it is reported: 
In our State (Arkansas) the Baptists support four general missionaries and a Superintendent of Missions; one college located at Little Rock, Ark., eight academies at other points in the State.

The actual amount of money raised and expended in missionary and educational work by the eolored Baptists in Arkansas ranges from $\$ 45,000.00$ to $\$ 50,000.00$ a year- $\$ 50,000.00$ for present year.

It is the women that do the larger part of the benevolent work in Negro churches.

In Mott's Sketches there is the narration of the work of a colored woman in New York city, who conceived the notion of child instruction and who earried it out under the most adverse circumstances. In the church economy of that day the child life was unconsidered, until this woman had planned and set in motion this very work. This was not long after the Revolutionary period.

In the early days of the Nineteenth Century another figure came into view-Jarena Lee. She was born in Cape May county, New Jersey, and attended school with the whites, getting the best there was to be had at that time. She was an ardent student, both of the Bible and in a general way, and possessed the gift of expression in an uncommon degree. Churches were widely scattered, and as a rule her kind, through prejudice, were without ministry or church. The need was paramount, and this woman with a will meant to fill it. She opened a Sunday-school in a private house, and the children for miles around came of a sunday to be eatechised and indoctrinated into the Bible lore. Jarena Lee had persistency, was possessed of a splendid memory and was naturally a voluble talker, and these with thorough goodness, unselfishness and large personal magnetism, made her the very one for such a crusade.

That was in South Jersey, and not only the fame but the work spread, and soon Philadelphia felt the force of her influence. Later on we find her in Pennsylvania, Delaware, Maryland, and even as far as Ohio. She first taught a secular school in Sonthern Jersey, but after awhile gave it up for mission effort in behalf of the church of her intelligent choice-the A. M. E. Chureh.

The gift of prodigious work was hers, and with the mental strength possessed by her there was a singular sweetness attached. This was attested by all the early fathers of the church, and proved how a woman could be strong in mind and action without losing the spell of her sex. The consensus of opinion from those contemporaneous with her gave her a position, for good, in the A. M. E. Church advancement, unmatched by any man of her day.

Her autobiography is a master bit of reason, and apart from its personal flavor throws much light upon the days wherein she figured, for the good of her kind, and especially for the church of her own communion.

Although the work of Mary Lewton, of Philadelphia, was more cireumscribed than that of Jarena Lee, it was a raluable one. She taught the children of her neighborhood, near Fourth and Fairmount avenues, at her home, and from her endeavors the Sulday-school of Lnion A. M. E. Church was begotten. ${ }^{1}$

1 Christian Recorder, 1909. 
The Ninth Annual Report of the Baptist Woman's Convention shows the following cash account:

\section{Receipts}

Balance, September 1, 1908 .

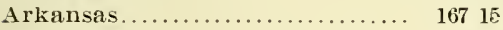

California................... 2625

Colorado ...................... 2962

District of Columbia ........... 4095

Florida ....................... 16341

Georgia........................................ 18011

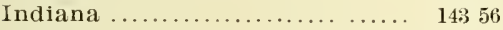

Illinois ..................... 31054

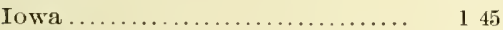

Kansas ..................... 10315

Kentucky .................... 15861

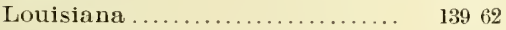

Maryland ........................ 3966

Minnesota ...................... 1745

Mississippi.................. 34725

Missouri ....................... $366^{3} 36$

New Jersey ......................................... 6201

New York................... 1370

North Carolina................. 2655

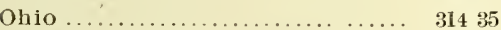

Oklahoma................... 23410

National Convention-Sales..... 21600

Miss C. G. Ewen................. 8775

Pennsylvania.................. 16875

Rhode Island.................. 145

South Carolina................ 16515

Tennessee ..................... 22755

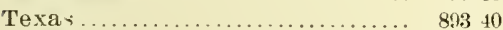

Virginia.................... 5544

West Virginia ............... 16799

Borrowed Training School Fund. 82534

Treas. Finance Committee...... 70710

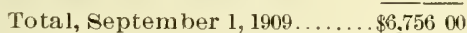

\section{Expenses}

Foreign Missions .............. \$1,145 50 Home Missions and Education... 14155 National Bapt. Pub. Board ...... 1125

National Bapt. Union ........... 825 Field Missionaries, salaries...... 83959 Field Missionaries, traveling.... 62477 Printing .................... 45825

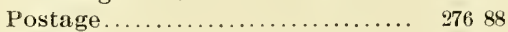

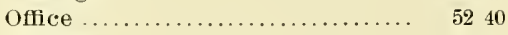
Supplies .................... 74974 Salaries ....................... 1,419 67

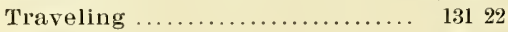
Field ......................... 2805

Stamp Day.................. 14118

Expense of Officers ............. 38945

Expressage and Drayage........ 4924

Total................. $\overline{\$ 6,71770}$

Reported by local societies and state organizations ........\$6,782 09

Total received by Convention. ........... 6,75600

Grand total receipts....... \$13,538 09 Total expenses Nationa.l Auxiliary ....\$6,717 70

Total expenses local and State organiza-

tions ..............6,782 09

Grand total expenses...... 13,499 79 Balance on hand sept. $1,1909 \ldots \overline{\$ 3830}$

Besides this, $\$ 5,594.97$ was raised for a yirls' training school. The convention reported 326 societies and 107 children's bands. They have distributed 200,000 tracts in ten years. One tract is "The Traveler's Friend." Some of its paragraphs are:

It possible, always purchase your ticket the day before you contemplate going on a trip. If this can not be done, leave home in ample time to avoid the rush that is usual at the ticket window a few minutes before the train leaves.

If the ticket must be shown at the gate, have it in your hand, where it can be displayed when ealled for. Do not wait until you get up to the gate and then hunt for your ticket in your pocket-book and grip, and thus delay the other passengers.

We notice so many people paying their fares on the train. This is a very bad policy, when it is possible to secure a ticket either at the city office or at the station before train time. Then, too, the company charges more for tickets on the train. Save money by getting your ticket beforehand. 
Don't stick your head out of the window at every station and hollo at somebody a block away, and don't talk so loud to your friends who may be on the platform that a person a block away may hear you. If they are not close enough for a conversation call them to you, and then talk to them, and not to everybody on the train and everybody around the waiting-room.

In States where the separate-car law is in operation we find the "crew" taking all kinds of liberties-converting the little apartment set aside for the colored passengers into a dressing-room, boot-black stand, a dump for dustpans, pillows, lanterns, clothing to change in at the end of the journey, and indeed anything. On many of the trains baggage-men, mail-clerks, conductors, brakemen, porters-all come in to arrange their toilets in the morning; and if there is a towel provided for the colored passengers it is so thoroughly used by the "gang" that it is not fit to wipe out the basin with. Sometimes the fruit-venders, conductors and brakemen whistle and sing, and "cut shines" of all kinds in the colored-passenger cars. Always enter a respectful protest and don't forget to write the operating officials.

And now a word to those trarelers who never get hungry until they see the "butcher" with his basketful of stale candies, peanuts, crackerjack, bananas, oranges, etc. There are some people who can not let the boy pass without making a purchase. These boys are generally very disrespectful to colored passengers. We have seen them uncork a bottle of smelling-salts and thrust it into the face of nearly everybody in the car. These boys have a lot of smart sayings and are a source of annoyance to respectable people. If they find that there are children on the car who will cry for fruit, or candies, they proceed to tempt them in order to force the parents to purchase something to satisfy their little ones. Those old lanterns, and pistols, full of cheap stale candy, are not worth buying, and just why so many of our people will waste their money buying circus food from these railway venders is a question.

These boys have learned that most negro passengers would rather feed their stomachs than their minds. They offer the white passengers newspapers and magazines, and offer negroes peanuts and crackerjack, candy and bananas. So many negroes eat that trash, that whenerer you want to read it is necessary to make a special request of the boy to bring you a paper or a magazine. Certainly some of us have a magazine or paper at home that we could take along with us to read, and we would not have to patronize the frisky ignorant "butcher." It is certainly cheaper to purchase lunches as far from the train and railroad station as you possibly can, for the nearer you get to the station the less fruit and candy you get for your money, and these delicacies sell at a premium on a railroad train.

The writer of these pages has trareled extensively and has had many experiences with passengers, "the road gang," conductors and porters. She has suffered much because of unequal accommodation for colored passengers, and has "begged" operating officials to gire Negroes who pay first-class fare firstclass acconmodations. Many promises have been made, but no improvement. She has also urged her own people to be careful of their deportment, look neat and clean, and thus demand what they can not hope to demand if they are hoisterous and unclean.

Other activities include the donation of postage stamps, giving of Christmas boxes, the sending out of field missionaries, etc. One of the missionaries reports: Homes visited, 1.341; mother's' meetings held, 14; 
churches, associations, etc.,visited, 262; money collected, not including month of August, $\$ 944.57$.

The Baptist Women's Missionary Convention, which met in Harrodsburg, Ky., July 2-5, published a report of the work accomplished for the year: Pages of tracts distributed, 3,141 ; religious visits made, 6,597; children induced to attend Sunday-school, 1,805; sick visited, 4,052 ; poor and suffering aided, 1,047 ; garments distributed, 704; money collected, $\$ 1,931.01$, of this amount $\$ 780.40$ was given for local work; for State missions, $\$ 38.06$; Foreign missions, $\$ 26.57$.

In the A. M. E. Church the Woman's Parent Mite Missionary Society reports these sums for the four years 1903-07:

\begin{tabular}{|c|c|c|}
\hline \multicolumn{3}{|l|}{ First Distriet } \\
\hline Philadelphia.................. & 1,400 & $\$ 3.08026$ \\
\hline New Jersey .. ................... & 946 & 1,01943 \\
\hline 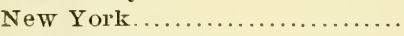 & 200 & 93600 \\
\hline 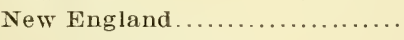 & 245 & 71100 \\
\hline \multicolumn{3}{|l|}{ Second District } \\
\hline Baltimore, Md................ & 1,373 & 6,14866 \\
\hline Virginia ...................... & 2,896 & $2,764 \quad 10$ \\
\hline \multicolumn{3}{|l|}{ Third Distriet } \\
\hline Pittsburgh .......... & 1,100 & 4.61515 \\
\hline 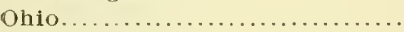 & 600 & 1,67203 \\
\hline 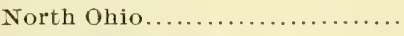 & 1,300 & 4,71200 \\
\hline \multicolumn{3}{|l|}{ Fourth District } \\
\hline 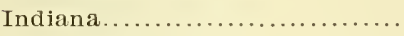 & 727 & 1,50952 \\
\hline Kentucky ................... & 310 & 52400 \\
\hline \multicolumn{3}{|l|}{ Fifth District } \\
\hline 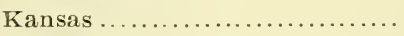 & 210 & 98783 \\
\hline 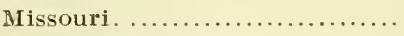 & 110 & 17100 \\
\hline Twelfth Distriet & & \\
\hline 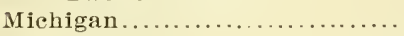 & 200 & 48000 \\
\hline 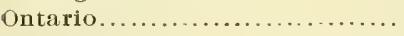 & 75 & 23100 \\
\hline Total $\ldots \ldots \ldots \ldots \ldots \ldots \ldots \ldots$ & 11,697 & $\$ 30,3619$ \\
\hline
\end{tabular}

The accompanying report says:

In the early days of the start of Allen's work, God directed the hearts of Bishops Campbell, Payne, Shorter, Wayman and Brown to urge the women of the A. M. E. Conference to organize. Not because there had been no effort in this direction previously, for in the early century of African Methodism women helpers were known. We find on the records Dorcas societies, women, the effect of whose unselfish labors extended broadly to alleviate the sufferings and wants of those in our immediate vicinity; also such societies as Danghters of Conference, whose interest extended over the whole of the conference and for over a quarter of a century aided the traveling ministers of the gospel. But the honored fathers, now sainted bishops, saw the necessity of not only broadening the Home work, but that the sympathies should accord with the ery of the heathen in the foreign lands and that the women of the A.M. E. Conference would push the cause to success, and that they would take great interest in the financial reeds of the foreign work, and with 
zeal and activity at heart unite forces and willingly respond to the call which was made.

After being organized at Washington, D.C., the next meeting was called at Bethel Church, Philadelphia, Pa., at which time there was a large gathering, many of which enrolled themselves as members of the Parent Mite Missionary Society.

But it is not only in the streets of our cities of America that we see the need of this Home Missionary work, for in the streets of Cape Town, Africa, I found the need of the same practical Christian service.

From August, 1874, the organization of the Parent Society, the bishops' wives were made vice-presidents of the organization and this gave them the right, wherever they were, to organize societies and push on the work through the whole connection. I, therefore, formed in Africa four societiesthe Sarah Allen, Eliza Turner, Florida Grant, and the Mary A. Campbell. With the simplest kind of constitution these societies went to work and God blessed their endeavors from the very beginning. Right in the streets of Cape Town I found my work and they found theirs. Young men that I spoke to on the streets were quite willing to go with me, and I was very glad to be able to take them to the schoolroom of the Institute, for the Temperance Society was permitted to hold its meetings there. The Colored Womer's Christian Association also held its meetings there under the fostering care of the A. M. E. Church.

Therefore, we need the extended appliances of Christian Association rooms. We must take these young people while their lives are yet before them, and bring them within the protecting walls of our A. M. E. Christian Association buildings, and not wait until they have learned from bad company to become lawless and wicked, and then run after them and bring them into the church and try to wash them with floods of heavenly grace.

Years ago poor mothers who had to go out to work by the day had to leave their children at home to fall into all kinds of danger, and even wickedness; but now, thank God, by the establishment of the Day Nurseries the young are protected from these dangers, and I think the very smile of Heaven must rest upon these establishments where the innocence of the young is guarded from the snares of eril, and mother's' hearts are no longer tortured by anxiety as to what their little ones are doing while they are out striving to earn their daily bread.

Now, whether it is the Association Buildings or the Day Nurseries, God speed the day when their numbers shall increase and their wise, practical sound sense mission service shall be acknowledged by the Church of Christ the world over.

Missionary work is not alone confined to financial reports; we go a step or two farther and encourage Temperance, Mothers' Meeting, Jurenile Work, Deaconess Wrork, etc.

The missionary spirit, as obtained in our belored Zion, assumed definite, tangible shape and character when, in 1824, its fir'st missionaries laid themselves upon the altar for service in the persons of Scipio Beans and _ Robinson, and both of them came from the Baltimore Annual Conference.

These results have been obtained through the rim and earnestness put forth by those having charge of the different departments of our work, name15: the Temperance Department, the Mothers' Meeting Department, Prayer and Praise Department, seconded by our Field Organizer and Lecturer. In this connection must be mentioned the Ladies' Alliance, composed of the minister's' wives, organized for the purpose of cultivating closer social inter- 
course between us, amounting in reality to a Round Table Circle.

There are many factors constantly at work in drawing large numbers of non-church-going laborers and their families from Georgia, Alabama and the Carolinas, and from Middle and West Tennessee, to Chattanooga and coal mines west and east therefrom. The great attraction in Chattanooga is facility with which our people obtain positions as skilled and unskilled laborers in the large number of furnaces, foundries, pipe works, and other factories in which iron, from ore to "pig," is converted into every form in which that mineral is coinmercially used. In these works the wages earned by our people run from $\$ 7.50$ to $\$ 21.00$, and in a few instances more, per week, and are paid weekly, with a constant demand for more labor. The raw material daily worked is enormous. As a result, miners for coal, hands for the coke ovens, quarrymen for rock, miners for ore and railroad hands for freight handling, find ready employment at good wages, and in great numbers. In consequence, the rush from lands and from congested eities is very great, and brings a large number of the uncultured, low moraled aud vicious with it. These must be met and must have the Gospel preached unto them.

Not only do their brethren, through the ties of race, see this necessity and recognize its importance, but the corporations, so generally considered heartless, also recognize the necessity of the Gospel for these men and, therefore, generally at each mine and oven plant outside of the corporate limits of cities, the company has erected a church and sometimes a schoolhouse, to accommodate the preacher, but provides no funds from which to pay him for his labor. He must subsist on capricious bounty, occasional charity and meager support from Mission funds, and that, too, as a rule, which has been gathered, mite by mite and penny by penny, through the energetic solicitations of you ladies and the worthy co-laborers whom you have the honor to represent.

In the A. M. E. Zion Church is the Woman's Home and Foreign Missionary Society, which was organized in Montgomery, Ala., 1880, during the sitting of the General Conference of that year.

At first and for a long time we worked under the direction of the Mission Board of the Church. About three years ago we were set apart as one of the Church Departments. We are now putting forth every effort to get a society in every church in the congregation. We find that those women who are organized are becoming more intelligent-they have Mothers' Meeting, discuss topics on the home life, do all manner of charity work and church work. Two-thirds of the money raised by the Society is sent to the General Treasurer for Foreign work; they retain one-third for their own use and do all the local work they wish. I have no record of the local work; that is sent to the Corresponding Secretary. We are increasing every year in the two-thirds sent to me. Several years ago we only raised seven or eight hundred dollars; last year we raised over $\$ 1,200$; and this year-and the year is not out until July-we have raised $\$ 1,500$. We are helping two schools and five missions in Africa. One of our teachers is an African who was brought to this country and educated at Livingstone College. We have a fund in reserve to educate African girls, to return as missionaries. It is not an easy matter to get the girls, it seems, but we have almost secured one. We hope to have two come at once.

Our work is divided into districts, so that we can have meetings and help the rural districts.

In widely separated localities church work in Benevolence is mentioned, as, e. g.: 
"Metropolitan Baptist Church Bureau of Information regarding respectable boarding houses, Twentieth and Tasker streets, Philadelphia."

"Church League for Work amongst Colored People, Twelfth and Walnut streets; under Episcopal Church. Organized 1897."

"All the Negro churches of any importance have their auxiliary societies, in the form of missionary societies, Epworth leagues, B. Y. P. U.'s, or C. E.'s."Dallas, Texas.

"There are numerous efforts being made by Negroes in Tirginia for their" social betterment in their churches and other organizations."

"The work of our own society here is to care for the sick and needy of the town, and it also contributes toward work in foreign mission fields."-Mission Society, Henderson, N. C.

"In addition to these, there are connected with the Zion Baptist Church two boys' clubs, classified as to age; a night school with classes in gymnastics and physical culture, aside from the ordinary routine."-Phobus, Ya.

"There are also connected with nearly every church some local society which would mean at least twelve or thirteen more than the above named."Charlotte, N. C.

"Of course I don't mention the list of organizations that are auxiliary to the churches, such as ' Willing Workers,' 'Sunshine Club,' and 'The Whatsoever Club.' Their object generally is to raise money for the churches, though they of ten do charitable work."-Kansas City, Mo.

We can best realize the extent of church work by considering the churches in one community-Atlanta, Georgia:

\section{Church}

Mt. Zion

Prospect Baptist

Proridence

St. Luke

Salem

Shiloh

springfield

Tillman

Trinity Tabernacle

Trinity

Willow Tree

Tabernacle

Zion Hill

W'heat street

Fair Haren Tabermacle Christian

Mission Church

Marietta Street

First Congregational

St. Paul's

St, Gabriel's Missions

Butler street Mission

Radclifie Memorial

Fraser Street Mission

Antioch

Bethlehem

Beulah

Central

Ebenezer

Friendship

Horton Street Chapel

Kelsey Tabernacle

Kennesaw

Lote street

Macedonia

Jagnolia Street

New Hope

\section{Denominalion}

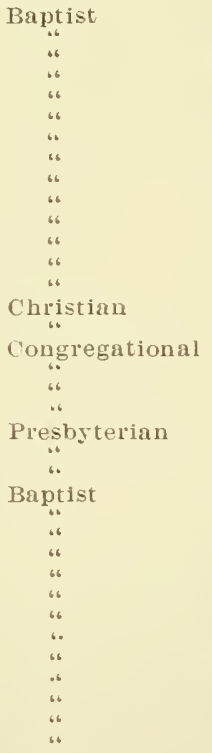

Church

MeKinles Temple

Mt. Calrairy

Mt. Moriah

ilt. Hermon

Frasiel Street

Mt. Olire

Mt. Olise

It. Pisgrh

Mit. Gilead

iIt. Pleasant

Allen Templo

Ariel Bowen Memoria

Bethel

Bridgeport

Butler Street

Holsey's Temple

IIt. ('armel

Shiloh

Central Avenue

Cosmopolitan

Pleasant Valley

St. Luke's

St. Matthew's

St. Paul's

West Mitchell

St. Phillip's

Holsey Chapel

Fort street

St. James Mission

St. Mark's

Wanen's Chapel

Turner's Chapel,

Turner Ilonumental

Zion

Swedenborgian

\section{Denomination}

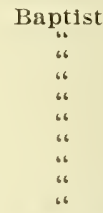

Methodist

"6

"“

"

"6

“

66

"

"

6

“

“

66

“

"

"

"6

Swedenborgian

One correspondent writes: 
"I am cot able to see myself (perhaps others smarter can) how we can ever hope to do much good for ourselves, in any way, so long as we foster so many different religious opinions; for doubtless you well know that nine-tenths of our differences come from our different religious opinions, which is bound to keep us dirided and weak, and so long as this state of affairs continues so long will we continue to be helpless in a manner and continue to howl about the white man not giring us a chance. I believe in making our own chances, but we'll never do it until we realize the folly of trying to ape the white man in everything he does. In my mind our greatest blunder is in the fostering of the multiplicity of churches of different faiths and our fraternal organizations. We should study to have but one church, that would be adaptable to our eircumstances, and but one fraternal organization likewise. Under such conditions our interests would become more mutual, and like our brother Irishman we would be united all along the line and could help ourselres."

Section 6. The School. Three questions arise in regard to Negro efforts for social betterment through schools: 1. What Negroes pay for their schools. 2. What benevolent efforts they make to improve schools. 3. What the benevolence of whites has done for Negro schools. Only the two last questions fall strictly within the scope of this report. It is, however, interesting to guote from a paper read before the twelfth annual Conference for Education in the South by a southern white man. From his tables we take the following figures:

\begin{tabular}{|c|c|c|c|}
\hline & Virginia & N. Caroline & Georgia \\
\hline Date.. & 1007 & 1908 & 1907 \\
\hline Total cost of schools............... & $\$ 3,308,08600$ & $\$ 2,958,16000$ & $\$ 2,850,21100$ \\
\hline Cost of Negro schools ......... & 489,22800 & 402,65800 & 506,17000 \\
\hline $\begin{array}{l}\text { Per cent. of total cost going to Negro } \\
\text { schools } \ldots \ldots \ldots \ldots \ldots \ldots \ldots \ldots \ldots \ldots \ldots \ldots\end{array}$ & 14.7 & 13.6 & 17.7 \\
\hline Per cent. of Negroes in population..... & 85.7 & 33.3 & 46.7 \\
\hline $\begin{array}{l}\text { Amount of public school funds not con- } \\
\text { tributed by white tax-payers; i. e., } \\
\text { contributed by Negroes, public util- } \\
\text { ity corporations, endow ments, etc... }\end{array}$ & $\$ 507,30540$ & $\$ 429,19700$ & $\$ 617,85254$ \\
\hline
\end{tabular}

"What is true of the school funds of the three states considered above is probably true of all the others" (i. e., Southern States). ${ }^{1}$

The following facts are taken mainly from R. R. Wright, Jr., "SelfHelp in Negro Edueation":

The African Methodist Episeopal Clurch supports twenty schools with 202 teachers and 5,700 pupils. The school property is valued at

1 Public Taxation and Negro Schools, by Charles L. Coon, Atlanta University Publications, No. 6. 
$\$ 1,132,000$. The anuual income of these schools is $\$ 150,000$, contributed by 300,000 people. Since 1844 they have raised $\$ 3,000,000$ for education.

The A. M. E. Zion has twelve schools with 150 teachers, 3,000 students. Value of their school property is $\$ 300,000$ and they raise $\$ 100,000$. In all they have raised $\$ 1,100,000$ for education.

The C. M. E. Church has six schools, and the A. M. U. Protestant Church three.

The Baptists have 120 schools run entirely by Negroes and worth at least $\$ 700,000$. They have 613 teachers, 8,644 students. The churches raise about $\$ 150,000$ a year for their schools, and the total money raised for these schools is $\$ 343,000$ a year.

Negroes also raise $\$ 700,000$ for their schools which are supported by white Baptist churches. During the past forty years Negro Baptists have contributed $\$ 6,000,000$ to their own education. Negro members of the M. E. Church have contributed in forty years $\$ 3,143,000$ for their own education. Negroes own $43_{10}^{\frac{9}{10}}$ per cent. of their schoolhouses in 155 Southern counties. Besicles this, many of those owned by the county were deeded to the county by Negroes.

In Macon county, Alabama, Negro patrous of six large schools added $207 \frac{1}{2}$ months to the school term and raised $\$ 6,532.44$ in 1906 and 1907 .

Negro students have paid in nine years $\$ 5,187,269$ in eash and work to 74 Negro institutions, or 44.6 per cent of the entire running expenses. Besides this they have raised money in other ways. For instance, the $\$ 100,000$ which built Jubilee Hall at Fisk University.

"The history of civilization does not show one other instance of a wholly illiterate race or nation reducing its illiteracy by half in a single generation.

"It is probably true that the Negroes pay possibly a larger percentage of the cost of their schools than any other group of poor people in America.

"The Negroes have paid in direct property and poll taxes more than $\$ 45,000,000$ during the past forty years.

"The Negroes have contributed at least $\$ 15,000,000$ to education through their churches.

:The Negro student possibly pays a larger percentage of the running expenses of the institutions which he attends than any other student in the land."

\section{A report from Virginia says:}

There is in Virginia an organization known as The Co-operative Education Commission. This is an organization for the white people. I want to briefly mention the work of this organization because of its influence in arousing a desire for social betterment not only among the white people but also among the colored people. In accordance with the suggestion coming from the commission, leagues were formed throughout the State known as School Improrement Leagues. The first business of each member of the league was to interest erers one in the school district, both rich and poor, high and low, in the work. 
The general object of a league is to unite the friends of public schools, pupils, teachers, school officers and other citizens in an effort to secure sehool improvements. The specific objects include the entire circle of school interests as providing for the social, civic, and literary training of the children.

The president of this commission at that time was Dr. S. C. Mitchell, Professor of Economies and History in Richmond College. He was also Rector of the Board of Visitors of the Virginia Normal and Industrial Institute, Petersburg, Va. On one occasion when addressing the student body he mentioned the possibilities of the School Improvement League among the colored people. It was at his suggestion that there was finally organized a Negro School Improvement League. There are now local organizations in nearly every school district in the State. The money that is raised by each local organization is used as the local league may suggest. One league may raise money to lengthen the school term; another to make some improvement on their building, grounds, etc. During the school year of 1907-08 the total amount raised by the local leagues throughout the State was $\$ 7,000$. During the school year of 1908-09 new leagues were organized to the number of 320 . Out of this number 275 raised money for local purposes. In Farmville one school raised $\$ 180$. The total amount raised by the local leagues throughout the State for $1908-09$ is $\$ 15,000$.

This organization is only a few years old. Its officers are in most of the large schools throughout the State. The influence of this organization is ever spreading, and plans are now on foot to make it even more influential. Nearly all the graduates of the Virginia Normal and Industrial Institute teach school, and one of the first things they are advised to do is to organize in the community where they loca te a school improvement league.

To me this is the strongest organization of its kind in the State. None of the officers receive any pay, but each local league uses the money it raises for school improvement.

Mr. W. T. B. Williams, field agent of the Slater Fund, writes:

The work which these schools are doing for their communities falls generally under four or five heads: Religious work of the Y. M. C. A.; Sundayschool work and preaching in the churches; social work, such as is done by women's clubs, the visiting of homes, almshouses, jails, etc.; educational work, such as making addresses, conducting teachers' institutes, organizing school improvernent leagues, holding night schools for training working girls in the line of their employment; helping farmers by means of farmers' conferences, demonstration farm work, monthly institutes, etc.; and contributing to and directing the amusements of their communities.-Southern Workman, Oct. and Nov., 1909.

The following sorts of social work are reported in different schools:

Atlanta University, Georgia.-The annual conference for the study of the Negro problems; fourteen reports published; University extension lectures; headquarters of a free kindergarten association, with five kindergartens for Negro ehildren; fifty traveling libraries.

Hampton Institute, Virginia.-Cabin visits, jail work, poor-house work, three night schools, two settlements, song service, home garden work, annual farmers' conference, annual Negro conference, rural improvement.

Penn School, South Carolina.-Home visits, trained nurse, monthly teachers' institute, temperance work, amusements, woman's meeting, annual farmers' fair.

Clark University, Georgia.-Farmers' institutes.

Atlanta Baptist College, Georgia.-Neighborhood settlement work. 
Florida Baptist Academy, Florida.-Public song service, lectures, woman's improvement association.

A mericus Institute, Georgia.-Sunday-school teaching, rural visiting, teachers' institutes.

Manassas Industrial School,Virginia.-Quarterly farmers' institutes, annual teachers' institutes, summer school.

Kowaliga Institute, Alabama.-Industrial improvement, amusements.

Calhoun. School, Alabama.-Mothers' meetings (semi-monthly), home visiting, dispensary, charity for the sick, amusements, lectures, annual agricultural fair, annual teachers' institute, land buying.

St. Paul Normal and Industrial School, Brunswick county, Virginia.Farmers' conference, land buying.

St. Paul School, Lawrenceville, Va.-Tncrease of rural schools.

Tuskegee Institute, -Negro conferelace, farmers' institutes, demonstration farming, couference agent, Negro Business League, county fair, county newspaper, model village, rural school extension.

Public School, Indianapolis, Ind.--Parents' elubs, a Christmas dinner for poor pupils, Civics and Hygiene, lunches, school gardening, truant visitor, night schools and playgrounds.1

There are many clubs like the following:

Three Times Ten Club, Tuscaloosa, Ala.- "We meet fortnightly at the homes of club members (alphabetically), when we attend to business and a literary and musical programme is had. As our club is federated with the Alabama Federation of Colored Women's Clubs, we of course help to sustain the Colored Boys' Reformatory at Mt. Meigs; and we assist charitably those in Tuscaloosa who are deserving.

"Our main object (locally) is to establish what we sorely need and have been striving to establish-a High School. With that purpose in view we purchased a plot of land for $\$ 200$, but have never been able to build. A few months ago a Tuscaloosa Educational dssociation, composed of citizens of the countr, was formed; to which organization we have donated the plot of land, with the understanding that they are to erect a High School.

"We have about $\$ 200$ in our treasury now, and as soon as a building is assured we will no doubt make a further donation, and shall continue to contribute."

Many local alumni clubs help their colleges by scholarships, funds, ete. At Fisk and Atlanta the alumni are endowing a chair by annual gifts. Other clubs like the "Eurydice Club," of Marion, Ind., the primary purpose of which is "to assist a worthy boy or girl to obtain a higher education, the secondary charity."

In some places, like Lynchburg, Va., the industrial work "in the public school is semi-philantliropic in that teachers do much extra work to make the innovations successful. Through the influence of our women this feature has been added, and the articles made go to the poor and unfortunate."

Teachers' associations are means of help. Among these are The National Association of Teachers in Colored Schools (founded 1903), R. R. Wright, president. The strongest of the State organizations are: Kentuckr State Colored Teachers' Association.

Tennessee State Colored Teacher's' Association.

lef. W. T. B. Williams in Southern Wrorkman, Oct. and Nov., 1909. 
Alabama state Colored Teachers' Association.

Texas State Colored Teacher's' Association.

West Virginia State Colored 'Teachers' Association.

Nearly all of the Southern States have some such organization. The preamble of the West Virginia Association states that its object is "to elevate the character and advance the interests of the profession of teaching, and to promote the cause of popular education in the State of West Virginia."

That the Negroes are bearing an increasing part of the cost of their own children's education is shown by the following table:

\section{Income of Atlanta University, together with the Amount Raised by Tuition; the Amount Received from the State of Georgia, and the Value of Student Labor}

N. B.-The amount of tuition is included in the total amount raised; the value of student labor is not thus included.

\begin{tabular}{|c|c|c|c|c|}
\hline & $\begin{array}{l}\text { Total } \\
\text { Money } \\
\text { Raised }\end{array}$ & $\begin{array}{c}\text { From } \\
\text { Tuition }\end{array}$ & $\begin{array}{l}\text { From } \\
\text { State of } \\
\text { Georgia }\end{array}$ & $\begin{array}{l}\text { From } \\
\text { Labor }\end{array}$ \\
\hline 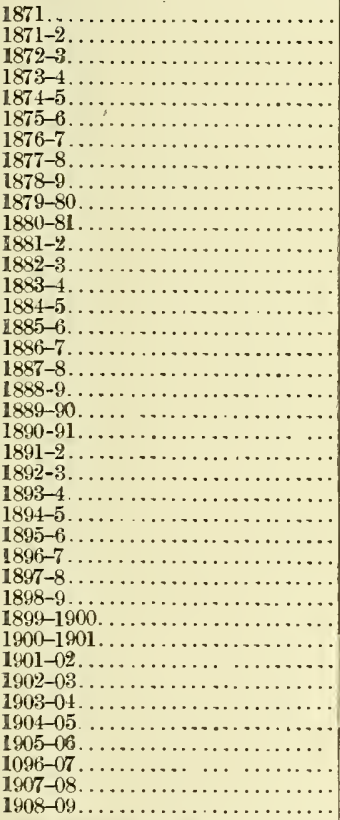 & 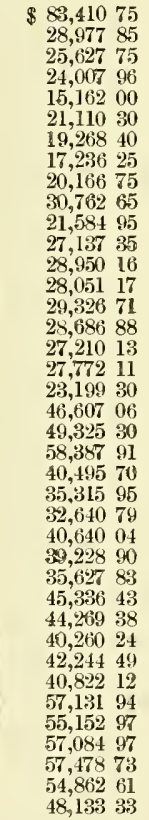 & 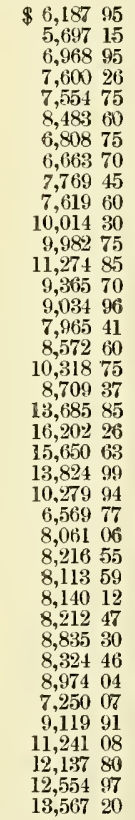 & $\begin{array}{r}\$ 8,000 \\
8,000 \\
4,000 \\
8,000 \\
4,000 \\
12,000 \\
8,000 \\
8,000 \\
8,000 \\
8,000 \\
8,000 \\
8,000 \\
8,000 \\
8,000 \\
8,000 \\
8,000 \\
8,000\end{array}$ & 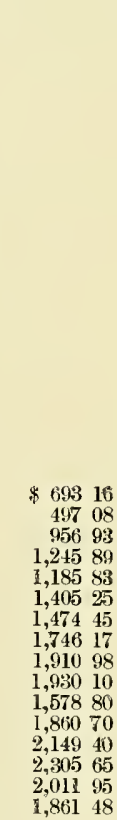 \\
\hline & $\$ 1,448,69601$ & $\$ 373,70270$ & $\$ 132,000$ & $\$ 24,81484$ \\
\hline
\end{tabular}

The total donations from colored people are unknown. The following, however, are the largest single items:

For memorial windows....................\$ 26000

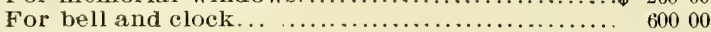

For Alumni Fund $\ldots \ldots \ldots \ldots \ldots \ldots \ldots \ldots \ldots \ldots, 0,067,79$ 
According to the Twelf th Bulletin of the Atlanta University, Negro students in nine years, or from 1898 to 1907 , paid in cash to $74 \mathrm{Ne}$ gro institutions $\$ 3,358,667$, and in work $\$ 1,828,602$, a total of $\$ 5,187,269$; which was 44.6 per cent of the entire running expenses of these institutions. In some of them Negro students paid as much as threefourths and in 24 of them they paid more than half of the total expense of operating the schools. In twelve institutions the average received from Negro students was more than $\$ 10,000$ per year, as the following table will show:

\begin{tabular}{|c|c|c|c|c|}
\hline INSTITUTION & $\begin{array}{c}\text { Cash Paid } \\
\text { by } \\
\text { Students }\end{array}$ & $\begin{array}{c}\text { Cash Value } \\
\text { of } \\
\text { students' Work }\end{array}$ & Total & $\begin{array}{l}\text { Average } \\
\text { per Year }\end{array}$ \\
\hline 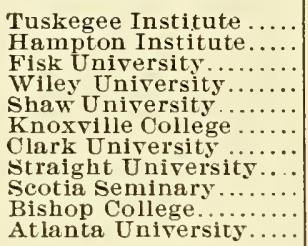 & $\begin{array}{r}\$ 217,798 \\
91,228 \\
261,576 \\
211,988 \\
168,241 \\
109,450 \\
116,757 \\
110,702 \\
64,589 \\
81,793 \\
82,487\end{array}$ & $\begin{array}{r}\$ 707,285 \\
549,618 \\
22,500 \\
15,927 \\
5,161 \\
24,000 \\
7,081 \\
4,916 \\
48,300 \\
12,587 \\
16,362\end{array}$ & $\begin{array}{r}\$ 925,083 \\
640,846 \\
284,076 \\
227,915 \\
173,402 \\
133,450 \\
123,841 \\
115,618 \\
112,888 \\
94,380 \\
98,819\end{array}$ & $\begin{array}{r}\$ 102,787 \\
71,205 \\
31,564 \\
25,324 \\
19,267 \\
14,828 \\
13,760 \\
12,816 \\
12,543 \\
10,487 \\
10,985\end{array}$ \\
\hline
\end{tabular}

The amount given by white people for Negro education has been enormous. The Freedman's Bureau made this report for the years 1866-70:

Expenditures for Schools

\begin{tabular}{|c|c|c|c|c|}
\hline \multirow{2}{*}{ YEAR } & \multicolumn{3}{|c|}{ EXPENDED BY } & \multirow{2}{*}{ Total } \\
\hline & $\begin{array}{c}\text { Freedman's } \\
\text { Bureau }\end{array}$ & $\begin{array}{c}\text { Benevolent } \\
\text { Associations }\end{array}$ & $\begin{array}{l}\text { The } \\
\text { Freedmen }\end{array}$ & \\
\hline $\begin{array}{l}1866 \ldots \ldots \ldots \ldots \\
1867 \ldots \ldots \ldots \ldots \\
1868 \ldots \ldots \ldots \ldots \ldots \\
1869 \ldots \ldots \ldots \ldots \\
1870 \ldots \ldots \ldots \ldots \ldots\end{array}$ & 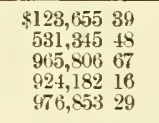 & 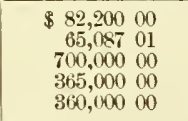 & $\begin{array}{r}\$ 18,50000 \\
17,20000 \\
360,00000 \\
190,00000 \\
200,00000\end{array}$ & $\begin{array}{rr}\$ 224,359 & 39 \\
613,632 & 49 \\
2,025,896 & 67 \\
1,479,182 & 16 \\
1,536,853 & 29\end{array}$ \\
\hline Total ........ & ( & & $\$ 785,70000$ & $\$ 5,879,92400$ \\
\hline
\end{tabular}

Dr. A. G. Haygood made this estimate in 1890:

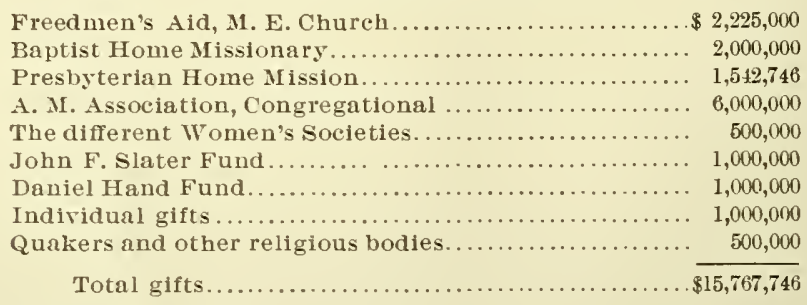

The larger funds are: 
1. The Peabody Fund of $\$ 2,000,000$ given in 1867 and 1869 . The income of this fund has gone principally to the education of the whites, but a small part has provided teachers' institutes and schools for Negroes.

2. The John F. Slater Fund of $\$ 1,000,000$ given in 1882. The income of this fund has been given exclusively to Negro schools and more especially to Industrial schools.

3. The Daniel Hand Fund of $\$ 1,500,894.25$ given to the American Missionary Association in 1888 for educating needy Negro students.

4. The Negro Rural School Fund, Anna T. Jeanes Foundation, is a fund of $\$ 1,000,000$ given by Miss Anna T. Jeanes, of Philadelphia. The interest is to be used to help rural education among Negroes.

To this must be added the recent Stokes Fund, which is partly for Negroes.

The American Baptist Home Mission Society has spent four millions in forty years. In thirty-nine years the M. E. Church has spent $\$ 7,819,397.46$, mostly from whites.

The Bureau of Education reports these receipts of Negro schools. Of the figures in the second column it is said: "Presumably the greater part of this amount should have been included under benefactions." Probably Negro schools have received over $\$ 12,000,000$ from whites in the twelve years 1896 to 1908 :

Negro Schools

\begin{tabular}{|c|c|c|}
\hline YEAR & Benefactions & $\begin{array}{c}\text { "Receipts } \\
\text { from } \\
\text { Other Sources" }\end{array}$ \\
\hline \multirow[t]{2}{*}{ 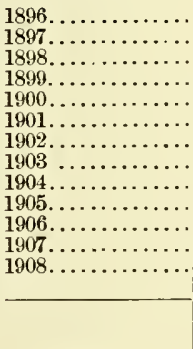 } & $\begin{array}{r}\$ 323,718 \\
305,050 \\
399,392 \\
433,014 \\
661,486 \\
505,244 \\
440,253 \\
446,477 \\
133,294 \\
397,289 \\
304,610 \\
470,994 \\
555,856\end{array}$ & $\begin{array}{r}\$ 610,946 \\
540,097 \\
476,560 \\
625,966 \\
677,977 \\
599,602 \\
562,258 \\
814,044 \\
840,305 \\
962,127 \\
734,479 \\
1,046,872 \\
1,129,263\end{array}$ \\
\hline & $\$ 5,376,677$ & $\$ 9,620,496$ \\
\hline
\end{tabular}

Section 7. Miscellaneous General Efforts.-Under this head may be mentioned various national organizations:

The Niagara Movement.-Founded 1905. Organized for political rights, legal defense, publication tracts, annual chautauqua, etc.

The Negro Business League.-Founded 1900. Organized to encourage business enterprise.

National Political League.-Founded 1907. Organized for political rights.

The Committee of Twelve.-Founded in 1904. Published pamphlets and tracts.

American Negro Acaclemy.-Founded 1897, to promote literature, science and art. 
These are general organizations, the survivors of a long line of similar societies, like the Afro-American League, the Afro-American Council, and a score of general conventions and local associations. To these must be added two organizations of whites and Negroes:

The Constitution League.-Founded in - to agitate the enforcement of the Constitution of the United States and particularly the 13th, 14th and 15th amendments.

The National Negro Conference.-Founded in 1909; designed to unite all efforts in a general movement toward securing for the Negroes all their rights as American citizens.

Beside these there are a number of conferences:

The Atlanta Negro Conference, to study the Negro problems. Founded in 1896. Has published fourteen annual reports.

The Tuskegee Negro Conference.-Founded in 1891. Devoted to farmers and teachers.

The Hampton Negro Conference.-Founded in 1896. Devoted to general discussion and study of the Negro.

To these must be added the work of the chief Negro secret and insurance societies, like the Masons, Odd Fellows, Knights of Pythias, etc. These are more than social and business organizations. A few quotations from local reports illustrate their benevolent work:

Our city, as you may know, is small. We have about seren or eight hundred colored families, Two serret societies: Masons and K. of P., with women auxiliaries. These organizations are a wonderful help to our city. They have done and are still doing much good work, socially and financially, for the betterment of our people. We also have three women's clubs that are engaged in a good work. They have proven themselves to be philanthropic to the letter. We have no charitable institutions as yet, to boast of, but are planning for something of that nature. The Negro Masons here are preparing a building to be used by our organizations in the near future.South Bend, Ind.

... We have a K. of P. Lodge. All of these organizations have done much for the social betterment of this small city,-Johnstown, Pa.

Aside from the secret organizations here in Texarkana among Negroes, all of which care for their members in sickness and death, paying sick benefits and a small death claim, there are no organizations here doing a strictly philanthropic work. These secret organizations, however, are very much in evidence and withal quite popular.-Texarkana, Tex.

The Woman's Burial Association is conducted entirely by Negroes. We have as many men in our association as women. But its name originated from a woman being the founder of it. We were organized the last Friday in August, 1902, with six societies and about 300 members. Now we number forty-one societies with 1,900 members. We pay out death-claim per member $\$ 90$. We hope to pay, after our annual sitting the third week in August, $\$ 100$. Our last associational year we paid out for death claims $\$ 1,876.56$. This year up to the present time we have paid out $\$ 1,378$, and we have four more to pay next month. It has been said by members of the other race that it is among the best steps the colored people have ever taken in this community.-Enfield, N. C.

We have any number of insurance organizations which give sick benefits, run wholly by the colored people, at least five or six operating here in 
the city. All of the above mentioned, in some way, do a little charity and social work for the uplift of our people.-Charlotte, N. C.

The following societies in Washington, D. C., united to celebrate the centenary of Lincoln's birth:

Crispus Attucks Relief Association.

Young Men's Protective League.

Young Men's Immediate Relief.

District Lodge No. 20, G. U. O. of O. F.

Waiters' and Ex-Taiters' Mutual Relief Association.

Bannaker Relief Association.

United Aid No. 1.

Elder Men's Relief Association.

Douglass Relief Association.

Section 8. Negro Philanthropists. Few races are more instinctively philanthropic than the Negro. It is shown in everyday life and in their group history. Some few of their larger philanthropies in America in early days have been recorded.1

\section{Jasmin Thoumazeau}

Was born in Africa in 1714, brought to St. Domingo and sold for a slave when he was twenty-two years of age, but afterwards, obtaining his freedom he married, and in the year $\mathbf{1 7 5 6}$ established a hospital at the Cape for poor Negroes and mulattoes.

More than forty years were devoted by him and his wife to this benevolent institution, and his fortune was subservient to their wants. The only regret they felt, while their time and substance was devoted to these destitute objects, arose from a fear that after they were gone the hospital might be abandoned.

The Philadelphian Society at the Cape and the Agricultural Society at Paris decreed medals to Jasmin, who died near the close of the century.

\section{Joseph Rachel}

'Joseph Rachel, a respectable Negro, resided in the island of Barbadoes. He was a trader, and dealt chiefly in the retail way. In his business he conducted himself so fairly and complaisantly that, in a town filled with little peddling shops, his doors were thronged with customers. Almost all dealt with him, and ever found him remarkably honest and obliging.

The philanthropists of England take pleasure in speaking of him: "Having become rich by commerce, he consecrated all his fortune to acts of benevolence. The unfortunate, without distinction of color, had a claim on his affections. He gave to the indigent, lent to those who could not make a return; visited prisoners, gave them good advice; and endeavored to bring back the guilty to virtue. He died at Bridgetown, on that island, in 1758, equally lamented by blacks and whites, for he was a friend to all."

\section{John Mosely}

Died-In this city, John Mosely, an aged colored man, well known from his industry, prudence, and integrity. Having no relations, he devoted his property to charitable objects. By his will he gave to the Hartford Beneficent

1 From Mott's Biographical Sketches. 
Society, one hundred dollars; to the American Colonization Society, two hundred dollars; to the Connecticut Bible Society, one hundred dollars; to the American Education Society, one hundred dollars; and after other legacies, the residue of his estate to the Domestic Missionary Society of Connecticut.Hartford Courant.

\section{Nancy Pitchford}

A woman of color, died in 1824 at Hartford, Connecticat, aged 67 years. For the first forty years of her life she was a slave. She sustained an excellent character, was for many years a professor of religion, and gave satisfactory evidence of sincere and lively piety. At the time of her death she had acquired, by her industry and care, more than four hnndred dollars; the whole of which, after paying the expenses of her last sickness and funeral, she left by will to charitable purposes.

The chief Negro philanthropists of our time may be noted as follows:

\section{Primus Parsons Mason}

Mr. Mason founded the Springfield (Mass.) Home for Aged Men. The first annual report says:

That the foundation for a charity like this has been laid by one man, demands that some notice of his life be placed among our records. According to the family Bible, Primus Parsons was born February 5, 1817, the youngest of seven children. His parents at that time resided in a remote part of Monson. They died when he was quite young, so that he was early thrown upon his own resourees. He worked for farmers in Suffield and Monson until he had nearly attained his majority, and then came to Springfield while yet a minor. On April 21, 1837, he purchased a house on the north side of the Boston road, borrowing fifty dollars on a mortgage to the seller, Daniel Charter. Engaging in very menial occupations, he accumulated some money and started to try his fortune in California in the decade before the Civil War. This was an unprofitable venture, and he soon returned to Springtield, without money but with a decided experience in favor of consecutive enterprises, and his business life theneeforward illustrated what can be achieved by industry, prudence, foresight, and judicious investment in real estate. As a trader he was shrewd but honest, and bought where he expected a rise in values. Until the end of his life he continued to improve his estate by the construction of new houses, as his means enabled him. In these days of thrift he felt himself alone among most of his companions, and on his death-bed lamented the improvidence that, in his opinion, characterized most of his race. Not till mature life did he learn to write his name, and this was the limit of his skill in chirography; but he supplied many deficiencies of education by a well-trained memory and a keen observation. He was thrice married, and the loss of all his family, including his danghter, perhaps turned his thoughts to the charity which he has founded. Upon this he had pondered long before he embodied the plan in his will, and had advised with sereral practical men upon its wisdom. Throughout his life, without race prejudice of any kind, the only limitations upon the charity suggested by him to the writer are contained in the phrase that he wanted to provide "a place where old men that are worthy may feel at home." He died January 12,1592 , and is buried in Oak Grove Cemetery.

His bequest was: 


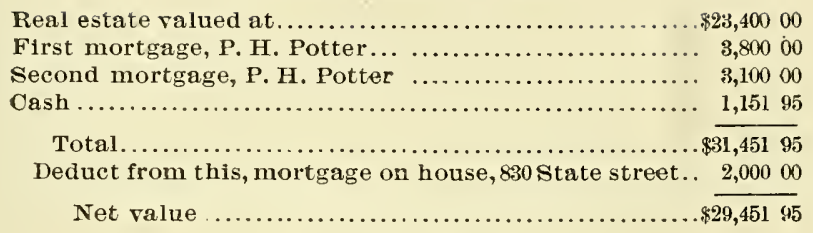

\section{Colonel John McKee}

Mr. MeKee, of Philadelphia, left an estate in 1896 of upwards of one million dollars in real estate, under the following conditions:

(1) None of his real estate is to be sold, nor any of his personalty disposed of, but whole estate is to be kept intact. (2) After making provision for small annuities for children, and grand-children being children of his deceased children, all to be paid out of income, the rest of income is to accumulate until enough has been provided to $(a)$ change certain city properties from dwellings into stores and dwellings, and otherwise to improve certain city properties; $(b)$ to construct houses on a certain large plat of city ground and improve same. Then (3) all the net income of his estate is to accumulate until after the death of all his children and grand-children, when the residue is disposed of under the following clause and in manner following:

In order that such a number of poor colored male orphan children and poor white male orphan children born in Philadelphia County as can be trained in one institution, may receive a better education, as well as more comfortable maintenance than they usually receive from application of public funds, I order and direct that after the death of all my children and grand-children, my Trustees to devote my entire residuary estate to the erection of a college with other necessary buildings, ample and complete, to accommodate at least 200 children, to cost not over $\$ 1,000,000$, on a tract of my land in Bucks County, to be called "The Colonel John McKee College," which name shall be inseribed on a large marble slab in front of the building, and in front of the building there shall be a statue of myself; all buildings and grounds to be surrounded by a stone wall. The college to supply all pupils with books and appliances. All pupils to be given a thorough naval education, similar to that given at Annapolis, my desire being that the pupils shall be equipped for service in war on sea.

In further detail, school is to have a band and the whole school turn out on the 30 th of May and march to Lebanon and the Catholic Cemeteries and decorate the graves of the colored and white soldiers and sailors. All pupils to wear uniform, and the whole, in short, to be supported and carried on out of the income from his estate. Children to be between the ages of 12 and 21 . The whole management is left in hands of the Archbishop of Catholic Church of Philadelphia, until after the death of children, etc. (he mentions his attorney as co-trustee), after which the school and all its affairs, being all the affairs of his estate, are to be managed by ten trustees to be appointed or elected from among the Catholic pastors in Philadelphia.

\section{George Washington}

The George Washington Educational Fund is a fund held in trust by six trustees appointed by the Cirenit Court of Jersey County, Illinois, under a decree of court which established in chancery the nuncupative will of George Washington, a Negro slave who died at Otterville, a small village in Jersey county, in 1868 . 
This fund, after peculations of white trustees and endless litigation, now amounts to about $\$ 22,000$, and under the terms of the decree above mentioned the trustees are required to use the interest arising from this fund for the purpose of educating young colored men and women of the State of Illinois. The trustees of this fund hold examinations from time to time in the city of Jerseyville. At these examinations the applicants are required to furnish satisfactory evidence to the trustees that they are residents of the State of Illinois, are of good moral character, and that they seek higher education for the purpose of fitting themselves for teachers of their race.

Another requirement is, that they shall have proceeded in their studies as far as possible in their home town.

This fund is now maintaining five students in Fisk University in Nashville, Tenn., and has educated twenty young men and women.

\section{Thomy Lafon}

The baptismal records in the archives of the Catholic Cathedral of New Orleans, at that time written in Spanish, attest that the late Mr. Thomy Lafon was born in this city on December $28 \mathrm{th}, 1810$. He died at his home, corner Ursulines and Robertson streets, on December 23d, 1893, at the ripe age of eighty-three years. His body rests in the St. Lonis Cemetery, on Esplanade avenue. He was a man of dignified appearance and affable manners. In early life he taught school; later he operated a small dry goods store in Orleans street, until near 1850. He was never married. Some time before the War of Secession he had started his vast fortune by loaning money at advantageous rates of interest and by the accumulating of his savings. Toward the close of his career he became attached to the lamented Archbishop Jansens, and began his philanthropies. By the terms of his will, dated April 3, 1890, he provided amply for his aged sister and some friends, and wisely distributed the bulk of his estate among charitable institutions of New Orleans. His estate was appraised at $\$ 413,000$, divided in securities and realty.

In recognition of his charity the City of New Orleans named after him one of its public schools.

Before his death he had established an asylum for orphan boys called the Lafon Asylum, situated in St. Peter street, between Claiborne avenue and North Darbigny street. To this asylum he bequeathed the sum of $\$ 2,000$, and the revenues, amounting to $\$ 275$ per month, of a large property situated corner Royal and Iberville streets.

Other legacies were to the:

Charity Hospital of New Orleans..................... $\$ 10,00000$

Charity Hospital, Ambulance Department ........... 8,00000

Lafon's Old Folks Home......................... 5,00000

Little Sisters of the Poor........................ 5,000 00

Shakespeare Alms House...................... 3,000 00

Catholic Institution for Indigent Orphans........... 2,000 00

And the following properties:

1st. St. Claude street, between St. Philip and Ur'sulines streets, ralued at............................... $\$ 1,50000$

2nd. Robertson street, between St. Philip and Ursulines streets, ralued at............................... 2,00000

3rd. Burgundy street, between Hospital and Barrack, ralued at................................. 2,000 00

4th. Union street, between Royal and Dauphine streets, ralued at..................................... 2,00000

St. John Berchman Asylum for Girls under the care of the Holy Family................................. \$2,000 00 


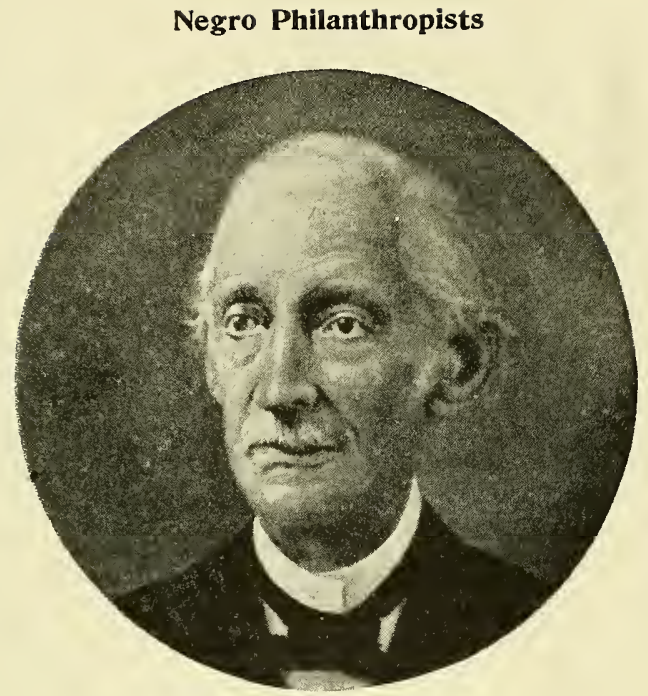

THOMY LAFON

Negro Philanthropist of New Orleans 1810-1893

And the following property:

1st. Burgundy street, No. 528, worth about............ $\$ 1,50000$

2nd. Dumaine street, Nos. 2129-31, worth about......... 2,500 00

3rd. Galvez street, No. 828, worth about .............. 1,800 00

4th. Toulouse street, Nos. $726-28$, worth about.......... 2,500 00

$5 \mathrm{th}$. Tulane arenue, No. 1402, worth about ............ 4,000 00

Asylum for Old Indigents, cor.Tonti and Hospital streets 15,00000

And the following property:

1st. St. Andrew street, Nos. 1586-38, valued at........... $\$ 6,00000$

2nd. Baronne street, No. 722, valued at ................ 4,000 00

3rd. Baronne street, Nos. 732-36, valued at ............ 8,000 00

4th. Canal and Villere streets, valued at............... 30,000 00

And another cash gift........................... 2,000 00

Society of the Holy Family, Orleans street........... 10,000 00

Straight University, of New Orleans, La.............. 3,00000

Southern University, of New Orleans, La............. 3,00000

New Orleans University, of New Orleans, La.......... 3,00000

Society of Jeunes Amis, of New Orleans .............. 3,00000

Eye, Ear, Nose and Throat Hospital............... 3,000 00

Mother St. Clair of the Convent of the Good Shepherd... 20,000 00

Mr. Lafon, in his will, underestimated the value of his estate, and after an appraisement was made it was found that his estate was worth twice as much as he valued it, and consequently all his bequests were doubled by his executors. I

\footnotetext{
1'These data were collected and furnished by Mr.J. F. Guillaume, of Straight University, New Orleans, La.
} 


\section{Stephen Smith}

Stephen Smith (1795-1873) was a Negro lumber merchant of Philadelphia, who left nearly $\$ 100,000$ to found the Home for Aged and Infirm Colored Persons.

A few other Negro donors follow: ${ }^{1}$

D. A. Payne to Wilberforce University ............ (?) $\$ 10,00000$

W. Gant to Wilberforce University ................. 5,000 00

J. P. Campbell to Wilberforce University ............. 1,00000

J. A. Shorter to Wilberforce University . ............ 2,000 00

H. S. Gordon to Wilberforce University ............. 2,100 00

F. Grey to Dooley N.\& I. School..................... 2,000 00

I. Lane to Lane College ........................ 1,000 00

G.A. and M. Walker to Straight University ..........., 1,00000

L. Bedford to Fisk University . ................... 1,00000

S. B. Morse to Atlanta University ................ 5,00000

R. F. Baptiste to Tuskegee ..................... 1,000 00

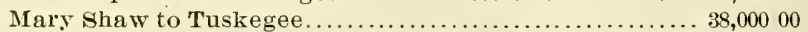

A. Mary to Orphans' Institute, New Orleans ......... 3,00000 Mrs. B. Convent to Orphans' Institute, New Orleans, "bequest." Dr. Augustus to Oblate Sisters, Baltimore......" "Jarge bequest."

Nancy Addison to Oblate Sisters, Baltimore.... . . .... $\$ 15,00000$

Louis Bode to Oblate Sisters, Baltimore.............. 30,00000

J. Parker to State College, Delaware................ 6,00000

Section 9. Types of Benevolence.-Charity. Coning now to the more strictly benevolent work of Negroes we may distinguish the following types:

(a) General Charity.

This is the most usual form of help, and being largely unorganized is difficult to measure. It is carried on by churches, clubs and individuals.

(b) Women's Clubs.

There are thousands of these for all purposes-social and benevolent.

(c) Old Folk's Homes, and Orphanages.

These represent the first and best institutional work.

(d) Hospitals.

These are never philanthropies, and are usually supported by whites and Negroes and often receive State aid.

(e) Young Men's Christian Association.

The colored branch has been developed recently, and Negroes have been refused admission to the white branches, even in many Northern cities.

(f) Social Literary and Art Clubs.

These include philanthropy as a by-product, or encourage directly literature and art.

(g) Libraries.

Public and prisate Negro libraries are beginning to be started, and traveling libraries.

(h) Dar Nurseries, Settlements, Kindergartens, Ciric Work, etc.

1 Taken in part from Wright: Self-Help in Negro Education. 


\section{Charity}

These forms of specialized and scientific philanthropy are just beginning to appear among colored people.

Let us now consider a series of local reports on each of these types. First we select at random local reports on charity :

There have been other bodies organized about in the city to supply the public schools with such ieeds as have been omitted by the Board of Education. Very often small bodies organize temporarily to do charitable work.Mobile, Ala.

There is a society called the Young Women's Christian Club which make it their business to look after the poor and needy in the way of clothes.-Los Angeles, Cal.

We have two charity clubs which work independently of any church. They are doing a great deal toward caring for the sick and relieving the wants of the destitute.-Dallas, Tex.

Preparing to do substantial work.-Galveston, Texas.

The Galveston Relief Association, an incorporated body, has for its object the building of a Home for Aged Colored People, at a cost of $\$ 15,000$. Looking to this end the association purchased and paid for ten acres of land, and has to its credit a small bank account.

The location is on the main land thirteen miles from Galveston, hard by the little town of Lamarque, a quarter of a mile from the station of the Galveston, Houston \& Henderson Railroad, and in the county of Galveston. The altitude of this plot of land is much higher than that of Galveston. This gives to it a beautiful view of several miles; the climate is genial and healthful, the soil is rich enough, by proper management, to make the Home almost self-supporting. The neighbors are generous and kind; in all, it is one of the best locations in Texas for an institution of this kind.

We believe there are three sources of moral elevation, absolutely necessary, yet to be opened to the Negro, without which we must still have the very bed of crime among us; viz.: 1. Home for the aged. 2. Industrial homes for the orphans. 3. Reform sehool for the incorrigible. For the aged there have been no home provisions made through private means, through denominations, or by county infirmaries, hence there people are a burden to themselves and to those who feel deeply for them.-Galveston, Tex.

One missionary or home improvement club, whose work is largely devoted to local charity.-Phœbus, Va.

One sewing-circle composed of ladies who sell their products and apply the returns to the relief of the destitute, mainly the aged.-Phøebus, Va.

Social Helpers' Club to benefit the indigent sick--Phœbus, Va.

This mission was organized by some women and men who desiren to help the unfortunate. Its work is as follows:

1. Making garments for the poor and unfortunate.

2. Making garments and other articles for sale to the general public, the proceeds to go to buy articles for the support of the mission and the purchase of material.

3. Instruction is given to such children, youth and older persons as can attend and give time to study.

It is purely an effort for social betterment, and no profits accrue to individuals from any of these ventures. Many of the most prominent people in the city are members.-Lynchburg, Va. 
When our members are sick we donate them fifty cents and go and tidy up their room. To-day we have in the sick treasury $\$ 25$. We have in the bank $\$ 200$. Since we have organized we have banked $\$ 1,579.69$. We have a Christian president. She is a woman that has her race at heart, and is always ready to help those that need help. Sometimes we are called on to go to the homes of the poor and sick. We take sheets and pillow-cases and tidy up their room.

Prudence Crandall Society provides poor children with shoes, that they may attend school.-Washington, D. C.

In the early part of 1900 , noticing the destitute condition of some of our people and especially among the children, the question arose in my mind, what could be done to help them to better their condition? In looking through Harper's Bazaar I saw an account of the needle-work guild of America conducted by our white sisters, and being impressed with the work I opened correspondence with them. In the meantime I called some of our women together to confer with them. One day my bell rang; on answering it I found myself face to face with the president of one of the branches of the needle-work guild of America. Asking her in she inquired if this was Mrs. - . I said it was. She said she was glad to know that I had become interested in the work, as it was "so much needed among your people," as she termed it. She said we could not have a Branch president, but might have a Section president under a white Branch. Of course you know that was not very pleasant to me. She informed me that the national president would be in Washington in a few days, and I would get all the necessary information from her. In the meantime there were about twenty-five of us meeting and planning an organization. A few weeks passed, and to my surprise who should call but the National President, a lady of refinement and culture; she expressed herself as being pleased at my efforts "to help your people," and also informed me that we could not have a Branch president of our women. After her visit we concluded to form an organization of our own.

April 20, 1900, we organized the First Branch of the National Sewing Council of the United States of America (incorporated). The first object of which is to collect new plain garments and to distribute them to men, women and children (who are needy). Men, women and children may become members by contributing two new plain garments each year or a donation of money.

We also have a Board of Directors engaged in Sabbath work, who seek and interest children in the attendance of Sabbath-schools of their denomination, in which they have been very successful. An auxiliary board was set apart April 20, 1908, to raise a fund for the establishment of a non-sectarian old Folk's Home, which is so much needed in the District of Columbia for our people. The Council have found it very helping in distributing provisions and fuel when needed. We also organized a sewing-school for small girls.Washington, D. C.

The Dorcas Home Missionary Society, which is connected with the Conecrd Baptist Church of Christ, at Brooklyn, is one of the oldest and probably the most widely known charitable organizations conducted by the women of any church among Afro-Americans in the North. During the year 1908 the society gave:

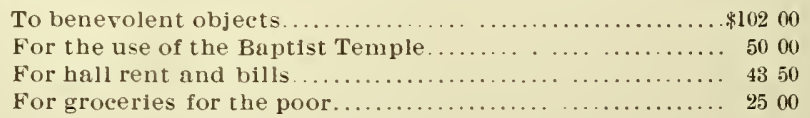




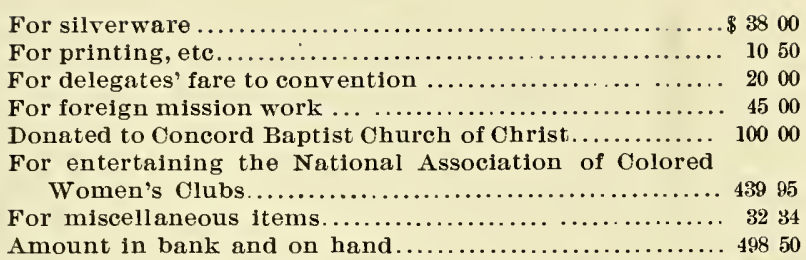

Four years ago the Dorcas Society began the observance of Woman's Day on the second Sunday in March. On such occasions, by consent of the church, all the services are conducted by women. These special days have been a great blessing to the church, as well as to the women that conduct them. The collections are given to the church and have amounted to nearly $\$ 500 .-B r o o k l y n$, N. Y.

The Benevolent Society was organized in 1879. Its present aim is the care for the sick and to assist in burying its dead. Also those who may need help. Organized with ten members to aid in caring for strangers who were sick and dying. At one time there was an enrollment of one hundred and twenty-five. The present enrollment is fifty. Supported a student at Wayland Seminary. Has a bank deposit, but does not own any personal property or real estate. It is the oldest society of colored women in the State.Detroit, Mich.

The Willing Workers Society of Detroit was organized twenty-one years ago, and is the oldest organization for charitable work among colored people in the State. The membership is limited and consists of fifty active members. The meetings are held weekly at the homes of the members, commencing on the first Thursday in October and continuing until the first Thursday in April. Although organized for work among colored people no line has been drawn, and in some instances relief has been given to worthy white people. The work of the society is carried on by various committees, who visit the sick, investigate calls for assistance, and give relief whenever possible. Food, fuel, clothing and money are distributed to persons seeking temporary relief, and regular weekly contributions are given to four persons who are worthy.

The dues consist of five cents weekly with an annual contribution of one dollar per member. Other funds are raised by making and selling quilts and other small articles which are contributed by members.

The society celebrated its twentieth anniversary last year.-Detroit, Mich.

Cornell Charity Club was organized eight years ago and had twelve members who lived in the same neighborhood, but later on this club branched out and now has sixty members living in all parts of the eity. We have limited our membership to sixty. We meet every Friday and do all kinds of good work, visiting the hospitals, jails, and institutions. Also doing charity work. We assist the Home for Aged and Infirm Colored People, also Amanda Smith Home.-Chicago, Ill.

The Willing Workers Club was organized in the year 1901 for the purpose of doing philanthrophical work. The membership of the club is about twenty-five women. It has done some very good work since its organization. It has given over two thousand dollars to needy causes, including churches, out-door poor, and other purposes, until 1907, when the club decided to work up a Rescue Home for girls and a day nursery, which we hope to open in the fall.-Stamford, Conn. 
We do charity work. We have sent a barrel of clothing to Sanford, N. C. One last year to New Port station. Had a ruminage sale to help the Union Baptist Church of Malden, and this year we are donating fruit to the sick. Sending Easter likes to the shut-in. Our club is over ten years old, but like all clubs, they are very apt to lose interest if they do not get an active head. I have done the work for the club very faithfully, and am now acting on the sick committee. We are getting ready now to meet the necessary funds for our yearly convention which meets in Springfield.-Malden, Mass.

I suppose you understand that we are in the federation of clubs. We, of course, take care of our own sick and help bury the dead. In fact, we try to help all humanity that comes within our reach.-Boston, Mass.

The club has stood for missionary work ever since its beginning. Many families in reduced circumstances have realized the goodness of the Lacy Stone Club. One of the most important committees connected with the club is the Flower Committee. If any member hears of any of our race who is sick at one of the hospitals, or at home, they report it to the society, and then the Flower Committee goes and carries flowers or fruit to them at the hospital or home. Not only flowers and fruit, but money and provisions are often carried to the sick. At the present time the club is working hard to get enough money together to start a Home for Working Girls. It is our intention, as soon as able, to rent a house and hire a matron, and let rooms out to the young women in our city who have no home except where they work.-Woreester, Mass.

The Cambridge Charity Club is purely philanthropic and the only organization of which I know that is not in some way beneficiary.

This club originated from a Mothers' Club with a small membership. About three years ago it was reorganized and renamed, and admitted into the Federation. The work is divided between a committee of four, who look up needy cases in a quiet way, in the locality in which each lives, and report to the elub. I think it unique among colored clubs, in that the work is done so unostentatiously. Names are not necessarily given in any public way to offend or humiliate, and set many needy and worthy people are temporarily relieved. Another splendid thing they have been doing, and are still doing, is aiding a young girl to get her education at Wellesley College.

Their membership is now over a hundred. Entrance fee is fifty cents and monthly dues ten cents. It has already expended between $\$ 150$ and $\$ 200$ in its three years of practical helpfulness.-Cambridge, Mass.

Some general criticism is as follows:

I can say for the people out here they are trying in every possible way to help our people better their condition.-Los Angeles, Cal.

There are five Federation clubs in our eity which do limited charity work; this being a small city and a thrifty people, there is little demand ordinarily of eharity; however, as a secondary purpose, when needed they all work.Marion, Ind.

Richmond, as might be naturally expected, takes the lead in the number of institutions for social betterment among the Negroes. But as was said by one of her leading citizens, "The people are not doing what they should do. I fear they are so engrossed in money-making that they have forgotten that there are some things better than money-making."-Richmond, Va.

As a rule the Negroes of this community accept charity with reluctance. A large number may be improvident, but by some means they manage to 


\section{Women's Clubs}

make both ends meet and only accept assistance in this connection in the last extremity.-Louisville, Ky.

In such charity Southern white people are especially willing and prominent:

There are a number of institutions of this nature in Louisville supported largely by Negroes, but not one that I know of supported entirely by them. The white people in this community are very friendly, and give very generously to charity, regardless of race or creed.-Louisville, $\mathrm{Ky}$.

These organizations are doing much good, and while maintained and managed by colored people are largely and generously supported by white people. -Louisville, Ky.

Section 10. Women's Clubs. Mrs. Josephine St. Pierre Ruffin, of Boston, and Mrs. John T. Cook, of Washington, D. C., were the pioneers in the club movement among colored women, although single clubs had long existed here and there. Mrs. Josephine S. Mates, Honorary President of the National Association of Colored Women's Clubs, writes:

That organization is the first step in nation-making, and that a nation can rise in the scale no higher than its womanhood, are principles which have come to be looked upon by the sociologist and all students of the development of humanity as self-evident truth; hence it seems quite natural to speak of one in connection with the other, i. e., organization and woman.

An inquiry into existing organizations among our women reveals the fact that most of these are auxiliary societies founded and controlled by men, or by the combined efforts of men and women; also, that usually they are secret orders, or connected with various ehurch denominations; and, furthermore, that in their respective fields much work of high order has been accomplished.

There is, however, one notable exception to the rule stated in the previous paragraph relative to organizations of women, and this is to be found in the "National Association of Colored Women," an organization founded and controlled entirely by women; and, within the scope of an article as limited as this must be, we shall confine ourselves to a synopsis of the work of this organization, composed exclusively of women, believing it to be the oldest, most completely organized, etc.; hence, affording the best test of the effectiveness of organization among our women.

The National Association of Colored Women was founded in 1896. The object, as well stated in Article II of its constitution, is, "To secure harmony of action and co-operation among all women in rising to the highest plane."

The organization has been well systematized and now contains at least fourteen well-developed departments, each under the supervision of a carefully selected superintendent. Among these departments one finds social science, domestic science, temperan ce, juvenile court, music, literature, Young Women's Christian Association,etc. Affiliated clubs may be found in forty or more of the States, and such clubs are rapidly increasing, as also the number of State and city federations.

The value and extent of the local work speaks for itselt in the number of hospitals, homes for orphans and the aged, reformatories, kindergartens, day 
nurseries, and other much-needed institutions, which, through the heroic efforts of the noble and self-sacrificing women that constitute these clubs, have been established.

Illustrations of these institutions, in good working order, may be found in New Bedford, New York, Buffalo, Chicago, Detroit, Kansas City, St. Louis, Washington, Charleston, New Orleans, and probably in many other cities and towns of which we have not positive knowledge at this moment; but a glance at the work in the cities mentioned serves to demonstrate what organization in the hands of the Afro-American woman is doing, not by fine-spun theories, but by actual work; and, if matters do not miscarry, the National Association-incorporated in 1904-financially speaking, eventually will be in position to purchase land sufficient to carry out certain plans that originated with its founders and that by no means have been cast aside.

Every well-organized body has its period of growth and development, as well as of fruitage; and, with State work well under way, we may confidently look forward to the time when the National body will be "bringing in its sheares;" meanwhile, through its State and city federations and individual clubs, it furnishes a most forcible demonstration of the value of organization among women, in the development of self-reliance, self-help and other elements so necessary to the advancement of a primitive people.

The preamble of the Association's constitution says :

We, the colored women of the United States of America, feeling the need of united and systematic effort, and hoping to furnish evidence of moral, mental and material progress made by our people, do hereby unite in a National Association.

The National Association has met as follows:

Washington, D. C., 1896-Founding.

Nashrille, Tenn., 1897-First convention.

Chicago, Ill,

Buffalo, N. Y.,

St. Louis, Mo.,

1899-Second convention.

Detroit,. Mich.,

1901-Third convention.

1906-Fifth convention.

Brooklyn, X. Y., $\quad 1908-$ Sixth convention.

The attendance at these conventions has been as follows:

$\begin{array}{cccc} & \begin{array}{c}\text { States } \\ \text { represented }\end{array} & \begin{array}{c}\text { Clubs } \\ \text { represented }\end{array} & \begin{array}{c}\text { Delegates } \\ \text { represented }\end{array} \\ \text { St. Louis...... } & 22 & 167 & 301 \\ \text { Brooklyn ..... } & 28 & 128 & 176\end{array}$

Of the Chicago meeting the Daily News said editorially:

Of all the conventions that have met in the country this summer there is none that has taken hold of the business in hand with more good sense and judgment than the National Association of Colored Women, now assembled in this city. The subjects brought up, the manner of their treatment and the decisions reached exhibit wide and appreciative knowledge of conditions confronting the colored people.

The present departments of the Association are:

$\begin{array}{lll}\text { Social Science, } & \text { Rescue Work, } & \text { Literature, } \\ \text { Parliamentary } & \text { Music, } & \text { Toung Women's Work, } \\ \text { Procedure, } & \text { Kindergarten, } & \text { Erangelistic Work, } \\ \text { Domestic Science, } & \text { Woman's Suffrage, } & \text { Jurenile Court, } \\ \text { Business, } & \text { Forestry, } & \text { Humane Work, } \\ \text { Art, } & \text { Mother' Clubs, } & \text { Religious Work. } \\ \text { Church Clubs, } & \text { Suffrage. } & \end{array}$


There is a Southern Federation and a North-East Federation and the twenty State federations:

$\begin{array}{llll}\text { Texas, } & \text { Kentucky, } & \text { Ohio, } & \text { Florida, } \\ \text { West Virginia, Maryland, } & \text { Colorado, } & \text { Virginia, } \\ \text { Iowa, } & \text { Michigan, } & \text { Mississippi. } & \text { Alabama, } \\ \text { Minnesota, } & \text { Missouri, } & \text { California, } & \text { Georgia, } \\ \text { Pennsylvania, Tennessee, } & \text { Indiana, } & \text { Illinois. }\end{array}$

Most of the large cities like Cincinnati (twelve clubs), Kansas City, St. Lonis, etc., have eity federations.

A report of the clubs of Missouri is as follows:

Clabs in the Missouri Federation:

Kansas City Federation.

St. Louis Federation.

Kensington Art Club, Kansas City, Mo.-Art work and discussion, rules on parliamentary usages and household hints.

Phyllis Wheatley Club, Kansas City, Mo.

Harper's W. C. T. U. Club, St. Louis, Mo.

The Woman's Musical and Literary Club, Spring field, Mo.-Raising money for a hospital.

Josephine Silone Yates Art Club, Sedalia, Mo.-Art work, charity work and raising money for a hospital.

Woman's Club, Jefferson City, Mo.-Charity, literary and civic improvement.

Kansas City Art Club.-China painting, embroidery and charity work.

Josephine Silone Yates Club, Clayton, Mo.-Charity and missionary work.

Central Missionary Band, St. Louis, Mo.-Home, foreign and educational work.

Art Lovers' Club, St. Joseph, Mo.

Ladies' Art Club Club, Armstrong, Mo.-Art work.

Modern Prescilla, Glasgow, Mo.-Art work.

Fulton, Mo., Club.-Charity, and lifting up the fallen.

Phyllis Wheatley, Ironton, Mo.-Literary and art work

St. Paul Missionary.-Missionary work, St. Louis, Mo.

Olive Branch, Lincoln Institute, Jefferson City, Mo.-Literary work.

Young Married Women's Thimble Club, St. Louis, Mo.-Intellectual improvement and charity work.

Reaḍing Circle, Lincoln Institute, Jefferson City, Mo.

Washington Club, Fulton, $\mathrm{Mo}_{0}$ - Charity and literary work.

Colored Woman's League, Kansas City, Mo.

Booklovers' ('lub, Kansas City, Mo.

Home Mission Society, Sedalia, Mo.

Yates Literary and Art Club, Lonisiana, Mo.

The Minnesota Clubs send this report:

The Afro-Amerisan Women's State Federation of Minnesota is composed of eighteen clubs from Duluth, Minneapolis and St. Paul, namely :

Adelphai Club, St. Paul.

Arbutus Club, Minneapolis.

Book Club, Duluth.

Dorcas Society, Bethesda Baptist Church, Minneapolis.

Florida Grant Mite Missionary Society, Minneapolis.

Inter-state Club, Duluth. 
Literary and Social, St. Paul.

Monday Art, St. Paul.

M. T. C. Art, Mirneapolis.

Palm Leaf, Minneapolis.

Pastor's Aid, Minneapolis.

Social Improvement, St. Paul.

Tuesday Industrial, Minneapolis.

Grant Mite Missionary Society, Minneapolis.

Sun Beam Club, Minneapolis.

Missionary Society, Minneapolis.

King's Daughters' Charity Club, St. Paul.

Zenith City Art, Duluth.

The Adelphai Club is a literary and philanthropic club. Books of poems and prose of all the leading authors are read in this club, especially those of colored authors, or any thing of interest to the race is read and discussed. Quotations are given at every meeting. This club helps to care for two old ladies, giving a sum of money every month for this purpose. It has a committee to $\Gamma$ isit the eity hospital erery month, taking fruit and magazines for the sick. It sends one dollar a month to the Mary Miller Earl Kindergarten, at Anderson, S. C.; also sends aprons. It meets annually at Jean Brown Martin Baby Home and Attucks Home, taking clothing, etc. It gives baskets of food at Thanksgiring and Easter time. Has started a literary society, It is through this club that the room was most beautifully furnished at the Jean Brown Home by the colored eitizens of St. Paul.

The Arbutus Club is a philanthropic club. Each Christmas a needy family is looked after. At different times baskets of food are giren to the poor. Last summer this club took the children of the Attucks' Home to a Sunday-school picnic. All of their time and money is spent for charity.

The members of the Book Club devote some of their time to sncial and domestic work, although it is a literary and philanthropic club. Papers are prepared by members, and quotations are giren at erery meeting. The greater part of the money raised by entertainments and donations is giren to st. Mark's A. M. E. Church, to aid them in erecting a new church, which will soon be finished.

The Dorcas Society is a church club. Its object is to pay the insurance money on the church property. They also assist in paying the pastor, sexton, or anything else that may come up. They aid the poor of the church, giring clothing, food and fuel. Annually they hold a sale or fair.

The Florida Grant Missionary Society works along missionary lines.

The Inter-state is a literary and philanthropic club. Papers on all the leading questions of the das are read. Quotations are given at every meeting. Some time is giren to music and household economy. Each year a book of historical facts is read in the club. Most all the money they raise is given to assist in building St. Mark's Church.

The Literary and Social is a church club. Gives weekly socials, with literars and musical program, selling refreshments. They papered the basement of the church and put in new gas-lights, and have aided the church in many ways.

The Monday Art Club does all kinds of needle-work. Classes in dressmaking, china-painting and millinery were formed. Anything pertaining to home life was discussed and demonstrated, such as cooking, table-setting, etc. Have held art exhibits, entertained many noted Afro-Americans, and have giren a little time to literars work. 


\section{Women's Clubs}

The W. T. C. Art Club does all kinds of needle-work. Have an annual art exhibit; give many successful entertainments, give aid to the needy, and do a great deal of literary work. This club presented to the Jean Brown Martin Home a portrait of Booker T. Washington, the work of a Mr. Stepp (colored). They make annual visits to the Attucks Home and Jean Brown Home.

The Palm Leaf Club does literary and philanthropic work.

The Pastor's Aid is a church club of St. Peter's Church. 'They assist the officers of the church in any way they can, financially and otherwise.

The Bethesday Church contributes to Home and Foreign mission work. It has paid an apportionment to American Baptist Home Mission Society and National Training School, at Washington, and made a monthly payment toward the salary of one native African teacher. Have contributed to a fund to educate a native African doctor studying in this country. Visit the sick and help needy in their home town.

The King's Daughters' Charity Club visit the sick, help the needy, and do all the good they can to up-build God's cause.

The Zenith City Art Club does needle-work and assist in raising money to build St. Mark's Church.

The Virginia report says:

We have connected with the State Federation of Colored Women of Virginia, clubs whose members are actively engaged in home, school, church, village improvement, rescue work, and social settlement, and they are doing good work. These clubs had been organized and working long before the State Federation was organized, so that explains how we can do so much work. in so short a time.

At our Second Annual Meeting, held in Richmond June 17 and 18, 1909, fortyseven clubs, representing 1,200 women, were reported.

We have succeeded in establishing a permanent organization and hope, by united and systematic effort, to give substantial evidences of the moral, mental and material progress made by our people.

The Illinois Federation has thirty-one clubs. The president's address of 1908 said:

Our clubs are indispensable factors in our elevation. As women, we must stand united for God, ourselves and our race. Some opposition has developed toward club work, someone having said that we were a set of butterflies on dress parade, but in my opinion the statement is false, for the most of our club women are the best housekeepers, the best wives and the best cooks; the most self-sacrificing women, ever on the alert to relieve suffering humanity, to the support of which they give a part of their small pittance of pin money. Our visits to the jails and juvenile courts show that many of our women are doing good work along these lines. Through organized effort, homes for working-girls, day nurseries and kindergartens are being established. Is not this progress? All this the work of our noble women. We would like here in this connection to mention: The Cairo hospital, fostered and under the supervision of the Yates Club of Cairo; the Anna Field Home for Girls, Peoria; Lincoln Old Folks and Orphans' Home, founded by Mrs. Eva Monroe and assisted by the Women's Club of Springfield; the Home for Aged and Infirm Colored People, Chicago, founded by Mrs. Gabrella Smith and others; the A manda Smith Orphans' Home, Harvey. The last of which we mention is the Phillis Wheatley Home for Wage-Earning Girls, of Chicago.

The Colorado Federation reports: 
At the last annual convention there were twenty-six clubs represented. They are charity, art and study clubs. All help to support the colored orphanage at Pueblo. One is raising means to build a home for girls and another to build a club house. Neither of these buildings is a certainty. The list is as follows:

Denver :

Life Line Club.

Sunshine Club.

Self-improvement and Social Club.

Pond-Lily Art Club.

Taka Art Club.

Coleridge Taylor Study Club.

Lucy Thurman W. C. T. L.

City Federation.

The League.

Colorado Springs :

DuBois Reading Club.

Twentieth Century Reading Club.

Silver Leaf Art Club.

Libby C. Anthony Club.

Harper W. C. T. U.

City Federation.

Dahalia Art Club.

Pond-Lily Club.

Treble Clef Music Club.

Pueblo:

Modeste Art C'lub.

Carnation Art Club.

Loyal Temperance Legion.

The Mothers' Club.

Doreas Watson W. C. T. U.

City Federation.

La Junta :

N. U. G. Club.

Cheyenne, Wyo. :

Searchlight Club.

The Women's Clubs of Arkansas report:

The first woman's club was organized February 11, 1897; first city federation June 7, 1905. The State was federated through the activities of Mrs. B. T. Washington and Mrs. Hunton, now national organizer; two State meetings since 1905, one in June, 1908, the other in June, 1909. In 1909 the clubs reported twenty-fice clubs with a membership of five hundred, represented by forty-four delegates at State meeting.

The city federations at Little Rock and Hot Springs are flourishing. At Hot Springs there is an Old Ladies' Home of seren rooms costing $\$ 1,500$. At Little Rock there is an Olil Ladies' Home of ten rooms costing $\$ 2,500$, and at Fort Smith one costing $\$ 1,400$. There is now being planned at Little Rock a Working Girls' Home under the auspices of the city federation. A Reform School for Colored Youth under the auspices of the State federation has been planned, and is now being prosecuted to arouse sentiment, influence State legislature and State oflicers, collect money, etc. There are School Improvement Associations throughout the State. These assist teachers and scholars in beautifying the grounds and school rooms, and in 
systems of rewards and incentives for better school work. These clubs do philanthropic and literary work.

\section{Some thirty clubs belong to the Ohio Federation.}

Ten of them report $\$ 500$ raised during the year 1908-09. They also report the following statisties:

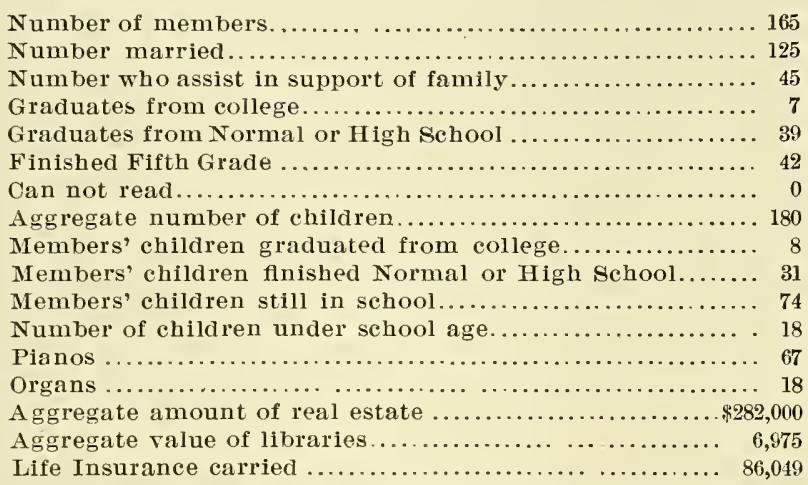

One of the most successful State Federations is that of Alabama. It has forty-five clubs. Of its last session it was reported:

The State Federation of Colored Women's Clubs, which began its ninth annual session in this city last Monday, came to a close yesterday afternoon. The Federation has established and is supporting a reformatory at Mt. Meigs for Negro boys. The organization is composed of representatives from the various Negro women's clubs throughout the State, and the Negro women are very enthusiastic over the work they are doing to reform way ward Negro boys. The meeting in 1907 was held in Selma.

Since that meeting the clubs have raised and reported to the officers $\$ 2,283.72$ and expended $\$ 2,236.97$. At the meeting that has just closed the Federation raised cash to the amount of $\$ 1,068.92$. After paying up all debts, they have now on hand $\$ 593.39$.

\section{The State Federation of Mississippi has seventeen clubs.}

We have done much work toward elevating the home life among the masses by paying especial attention to plantation club work and establishing community clubs where possible.

One particular club-the Woman's Progressive Club of Alcorn College-the oldest club in the State, and the one with which I was connected for eleven years, has done much along this line, holding club meetings right in the plantation homes, showing the women of these homes how to improve themselves and their homes. We have seen many evidences of good results from this kind of work.

The Woman's Christian Union of Vicksburg and the State Federation have adopted this work as State work, and now all of the clubs are bending their energies toward its support.

The Phillis Wheatley Club of this town-a club of forty-six members-has furnished a reading-room known as the Phillis Wheatley Reading-Room.

Many clubs do literary work, studying both literature and art. At the last State Fair several pieces of work from club women took first premiums. All 
of our clubs do some charity work. We hold our next annual meeting at Mound Bayou-the Negro town.

Some reports from typical women's clubs throughout the country follow :

The Women's Home Progressive Club was organized Oetober 19, 1902, with a membership of seventeen. Club work in this locality was a new feature and therefore met with considerable criticism, but, nevertheless, we went on. During the year 1903 we gave twelve dollars on a piano for the city schools besides helping a number of sick and destitute ones during the winter months. In 1905 the Club donated ten dollars to F. I. S. College. The following departments were organized: Educational, Business, Charity, ard Industrial. Although our club is composed mainly of teachers or those capable of teaching, only the last three have claimed our attention so far. In our Educational Department we have only had a literary program once a month but planned to take up a regular reading course later. In the Business Department we have a saring department where each one deposits at each meeting any amount she may see fit, usually twenty-five cents. Last year our savings ran up to nearly fifty dollars.

In the Charitable Department for this year we helped to put fountains in the publie sehools.

Our Industrial work for this year was basketry. We made a number of beautiful baskets and hand-bags with raffia.-Paris, Tex.

E. W. Bailey, Principal of the school, in a brief talk stated that the colored women's elubs had been working for a year in order to raise $\$ 125$ with which to aid the eity in putting water fountains on the campus of the colored school ground. As a result of their efforts, the representatives of the federation then present had in their hands more than $\$ 100$ to present to the board of education for the laudable cause. The presentation speech was made by Mrs. Hannah Simms, president of the City Federation of Colored Women. In her talk she assured the superintendent and all present that the colored women have it in their hearts to do something themselves to aid in educating the children of their race while the white people are taking such deep interest in providing the necessary facilities for their education. She further stated that the superintendent of city schools had asked for $\$ 125$ and that the $y$ were ready to place with him $\$ 126$. Prof. Wooten in pointed remarks aceepted the contribution and he gave assurance that the a mount given would be highly appreciated and that he is ever ready to help those who struggle to do something for themselves.-Paris, Tex.

There are at least ten women's clubs that are devoted to social betterment. One of these the oldest, "The Women's League" is purely charitable. They are buying a home for working girls, strangers who come to town, etc. They have paid about $\$ 700$ on it so far. One club is purely literary, "The Booklover's." The others are:

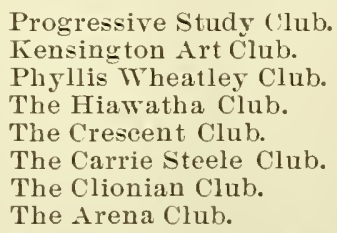

The last eight named do sereral kinds of work: some charitable, some literary, some art needlework, china painting, etc. All do some charitable work. 


\section{Women's Clubs}

Nine of the ten are in an organization called the City Federation of Clubs which meets monthly, and is a sort of club clearing-house. There are over three hundred women in these clubs.-Kansas City, Mo.

Woman's Twentieth Century League-main object to support Reformatory.

Captain W. D. Hargwood, superintendent of the Boys' Reformatory at Mount Meigs, Ala., was in the city Tuesday, and returned the same night with a youthful criminal that had been turned over by the court to the custody of the reform school.

The transportation expenses of the superintendent and boy were paid by the Woman's 'Twentieth Century League.

When it was learned that the little unfortunate was veryscantily clad, and had neither shoes nor stockings on, a christian-hearted mother donated a complete outfit of good clothing and underwear, besides shoes and stockings. -Mobile, Ala.

Our Woman's Club of this city is not yet able to give full support to any particular work. We care for a few old and sick people. Our plan is to have a reading-room and to look after the young children of the laboring class of women during the day while they are away from home at work.-Gainesville, Fla.

The City Federation of Colored Women care for the sick and needy and are trying to raise funds to build an Orphans' Home and an Old Folk's Horne.Pensacola, Fla.

Sojourner Truth Club aims to build a Home for Working Women and Girls. They have succeeded in raising money enough to purchase a lot upon which to erect a building.-Los Angeles, Cal.

The Woman's Loyal Union owes its formation to an unusually large meeting held in New York eity, in aid of Miss Ida B. Wells, now Mrs. Barnett, at that time editor and publisher of a paper in Memphis, Tenn., whose press on account of her fearless utterances had been destroyed and her life threatened. At this gathering a generous purse was secured for Miss Wells: The meeting proved such a success, and the enthusiasm aroused among the people was so great, that it was considered wise and fitting to found a permanent organization embodying the sentiments elicited by the meeting.

The Woman's Loyal Union was therefore organized December 5, 1892. The motto of the club is, "Vigilant, Patriotic, Steadfast." This association, whose initial effort was the defense of the oppressed, continaed to work along race lines. In accordance with the clause of the constitution, "The object of this Union shali be the diffusion of accurate and extensive information relative to the civil and social status of that class of American citizens of African descent-i.e., Afro-Americans-that they may be led to an intelligent assertion of their rights," etc., a circular letter containing questions for information respecting the condition of the people was widely distributed throughout the South. Toward the dissemination of race literature Congressman White's speech delivered in the House of Representatives was sent to the celebrated Union League of Manhattan, to the Christian League, and to other prominent parties; and leaflets issued by the Afro-American Council were also sent to white clubs and to liberal-minded people.

Alro when the mentioned Council was soliciting funds to try a test case in the courts of the South, the sum of $\$ 10$ was given by the club to assist this worthy cause, and a like amount to the Citizens' League to protect the sufferers in the race riots which took place in New York city in 1900. An account of these riots, issued in pamphlet form, was circulated in the convention 
of the Northeastern Federation of Women's Clubs, held in Brooklyn in the summer of 1902 .

When refugees from Oklahoma, the unfortunate victims of a Liberian scheme, in a destitute and helpless condition, were stranded in cars in Jersey City, the Women's Loyal Union came to their relief, placing the matter in the hands of the Ways and Means Committee of the association. The amount of $\$ 20$ was furnished this cause and the needy ones were supplied with temporary homes and otherwise succored in the hour of their great distress.

In relation to further financial assistance rendered by this club, a sum of money was given to the school at Manassas managed by Miss Deans, and $\$ 10$ to the Waller Fund created by the New York Press toward the relief of Ex-Consul Waller, then confined in a French prison on the island of Mauritius.

From a feeliug of reverence and affection for the memory of John Brown, money was also, at one time, sent to his daughter, then in dire need. The club gave a substantial amount toward the purchase of the Northfield Home, a building at Northfield, Mass., which the Northeastern Federation had agreed to secure as a center of rest and recreation for club members during the summer.

In the line of educational work two children were supported for several years in a kindergarten in Florida, and money contributed toward the maintenance of a school in Georgia.

Emphasizing the desire to keep in memory the heroes of the race, the death of Frederick Douglass was observed by appropriate exercises, including a memorial poem written by the recording secretary.

Under the third section of article two of the constitution of the Union, in the autumn of 1905, a Protective and Industrial Home for Working Girls was established by the club, and continued for nearly two years with a reasonable degree of success; its object was to shelter and protect girls who come North to secure employment, and to aid them in the accomplishment of their plans. The Home was suitably equipped, provided with a competent matron and managed by an efficient House Committee; and effective work was accomplished during the period of its activity; but it has been temporarily suspended on account of changes made by the owner in the premises where it was located. The aim of the association, however, is to re-open the Home as soon as sufficient funds can be obtained and proper accommodations secured, when the work can be developed on a larger scale and with greater facilities for usefulness.

The membership of the Woman's Loyal Union is not as large as it has been on account of rarious changes made in the community where the club has worked since its organization. The present enrollment is twenty-five.New York.

The Semper Fidelis is a club composed of twenty-five married ladies. It was organized about ten years ago, mainly as a literary club, but added the (haritable feature at once. Some years it has given scholarships to deserving pupils in the Negro High School. It has also made large donations to the Industrial Department of the High School. Each year it makes donations of money, clothing, and other necessities to the Old Folks and Orphans' Home of this city, besides helping other needy persons in the city. Since the beginning of the State Reformatory for Negro Boys, several years agoand which does not receive any state aid as yet-it has taken a very active part in helping to establish and maintain the same.-Binmingham, Ala.

The Anna M. Duncan Club was organized in September, 1898. The first 
work they did was to issue a call for the organization of a State Federation of clubs, which was effected December 26, 1898. After this organization was perfected, the clubs seeing the need of a city federation, they organized one. They took as their work the building of a State Reformatory. Each Sunday afternoon different members would visit the jail, and seeing how our young men and boys were being sent to the chain-gang and farms for the least offense, they determined if possible to save our boys from being placed in prison cells with hardened criminals, and by this means coming from prison much worse than when put in; in fact, becoming full-fledged criminals. They worked at this for two years, until they finally interested the State Federation to adopt the work. Of this State Federation Miss Anna M. Duncan was the first president. She was also president of the club until her death. Her undying devotion to the work of saving the boys, and her untimely death, caused the club in honor of her memory to adopt the name of the Anna M. Duncan Club. At first the number of members was unlimited and the club met from church to church; then the number was limited. We have now thirty active members. Our special work is the Reformatory that has been established in this city by the State. We have one building, a cottage of about eight rooms, ard a farm of twenty acres that has all been paid for by the Federation. The cottage cost something over twelve hundred dollars. This club is an important factor in the running of the Reformatory, the president of the club being chairman of the Board of Managers and its curresponding secretary being a member of the Committee.

These women are untiring in their efforts to make the Reformatory work a success. While the Reformatory is their chief work, other objects of charity have not been neglected. A child has been kept in the kindergarten, another in the Normal School of this city by the paying of tuition and furnishing books; another has been sent to and from Talladega College, she having a scholarship but unable to pay the railroad fare to and from school.

In this city is the Hale Infirmary, a large and commodious building built by Mrs. Ann Hale in memory of her husband and children. While Mrs. Hale gave the building, the running of the house depends upon the donations given it. To this object the clubs give thirty dollars a year. Clothing, food and fuel have been given to the needy poor during the year to the amount of thirty or forty dollars.

During last year the Club collected three hundred and sixty dollars. Of this amount two hundred and fifty was given to the Reformatory. The Club hopes to be able to double this amount during the present year.

We study different authors for our own improvement. Papers are read and events of interest to the race are discussed. At different times we have had men of note to lecture for us, and the money so raised has gone into our Reformatory Fund.-Montgomery, Ala.

The Woman's Club of Marietta was organized in September, 1900, with eleven members. One of the objects of the elub is to help the needy in and about Marietta. For several years the charity of this club was shown by donations of raw food, wood, bed-clothing, garments and medicine to the poor and needy. In very rare instances money was given, with which to buy a needed article. Many yards of cloth have been bought and made into garments by the ladies for orphans and sick people. Once we gave a Christmas tree for orphan children. About twenty-five children received two and three presents each. A neat little program was rendered by the children and added much interest to the occasion. But we have stopped this promiscuous 
giving. We help an individual now, only when he is in extreme need and applies to us. We are keeping our pennies together for the purpose of establishing a "Home." At first we thought an Orphanage, but now we think a Home for the Friendless, orphans included.

We have in the bank abont eighty dollars and it is drawing interest. We have just decided to bny a two-acre tract of woodland in a good Negro settlement three miles from the center of town. Before thirty days I think it will be in our possession. Then we shall go to work to build on it.

Our membership is small, never having been more than twenty at any one time. Being purely philanthropic, women are not very anxions to join.-Marietta, Ga.

The Woman's Clnb was organized with ten members. The number has grown to thirty. There are various departments: the Child Cultnre Department, the Jurenile Department, the Domestic Science Department, the Prison Department, the Sick and Aged Committee and the Orphan Committee. All of the departments and committees are active except the Domestic Science Department which has been closed for some time on acconnt of lack of funds. Through these various committees we are bronght in tonch with all classes. IIothers' Meetings are held from time to time in the different churches some time during the week, also sometimes on Snnday afternoons. They are held to suit the collvenience of the people.

Nany are the needy ones who have been relieved at the hands of the Woman's Clnb.

To help us in onr charitable work twenty members have taken stock in a nillinery project. The value of each share is five dollars. Some have taken half of a share. Ten per cent of the undivided profits will be given to the club to further its work of charity. The little millinery store was opened last month and we are praying for success.-Athens, Ga.

The St. Pierre Ruffin Club, the oldest club here, is composed of twenty-five married ladies, who are engaged in the work of social and benevolent nplift. Tre feel that the social side of life has been greatly inproved throngh this ageney.-South Bend, Ind.

The Daisy D. Walker Clnb is composed of twelve young ladies. They make a specialty of supplying the sick with milk and frnit and giving of flowers to the dead. They are also engaged in literary work.-South Bend, Ind.

The Mothers' Society studies and discnsses home-making, the rearing of children, etc. They have in hand the building of a hospital for Negroes, and have collected a considerable amonnt. They are receiving generons support from the race. - Frankfort, $K y$.

The Francis E. W. Harper Club of Portland, Me., was organized in 1902 as a literary club. It has fourteen active members and one honorary member.

Since its organization the club has been engaged in philanthropic work. ( hur object is to build a home for women-a place where the aged may pass their last days in comfort and where young women may find a home for smail compensation.

Although the field here is very small we find plenty of work at hand, and in many cases co-operate with one of the ladies connected with the Associated ('harities of this city.

We have a small bank account which is increasing gradually. I am also pleased to add that this year the clnb has been unnsually prosperous.-Portland, Me. 
The New Bedford Mothers' Club is carrying on work for neglected and hoineless children. This work was started in 1904 . We are doing a good work which is limited only by our means. We have a sum of money in the bank which is known as the Children's Home Fund, and will be used when the work warrants it in building a home for these waifs. This work appeals especially to a mother's heart.-New Bedford, Mass.

The Ann Arbor Women's Club was organized in 1898 with ten members. From the first we have felt that there was need of an organization to help over the rough places, and we ten went to work. We have given nearly $\$ 700$ to aid the needy, possibly not all in ready cash-although much of it has been cash-but we have given clothes, food, fuel, bedding and flowers to the poor of our own city, to say nothing of having sent quilts, rugs, food (including canned goods, fruit, vegetablés, sugar, ete.), clothing and money to the Phillis Wheatley Home in Detroit. We also placed an inmate at the Home for which we paid $\$ 200$. Each year we give to each of the two churches, besides when we have our annual sermon preached in October we give a special collection to every chureh. Our club now numbers twenty active and two honorary members, and as we are making up our report for the State Convention we feel proud of the work done this year, as it has been the most successful one during our existence. We are contemplating having a flag day. We have not purchased any real estate yet, but that is the point that we are aiming for, and hope before long to make the first payment on a piece of property. We also contribute toward the support of a district nurse in our eity. At the Christmas Tide we send dinners to the poor that we know of and fruit to the sick.-Ann Arbor, Mich.

The women of Vicksburg, after several attempts, succeeded in 1905 in effecting a permanent organization. These club women were banded together to do charity work, but for a long time could not decide what work was most necessary. They finally conclucled that some provision for caring for the old folks and orphans should be made. This work was immediately undertaken by them. They began at once to solicit funds from the people of this immediate vicinity for the purpose. They had to overcome the difficulties common to all incipient work. Many felt that nothing would ever come of the movement and refrained from taking a part.

Notwithstanding this, they selected a suitable lot about a mile from Vicksburg, containing a large ante bellum residence, and contracted to buy the same for $\$ 1,200$.

They have now paid for the place. They have bought also two smaller lots in the same locality, and are now collecting funds to repair the Home, after which they intend to open it for the reception of the aged poor.

They have no permanent source of support. Their collections have been made solely in this community.-Vicksburg, Miss.

In January, 1903, having for some time seen the necessity for a club in our city whose object would be the help and uplift of the women and girls of our race along many lines of usefulness, $I$ asked a number of women to meet at my residence to organize such a club. Nine responded and we formed what is known as the Afro-American Woman's Industrial Club. We decided to meet twice a month, the first meeting being a strictly business meeting and the second a social meeting to which our friends are invited; the meetings being held at the different members' homes.

During the first year of our organization we joined the Northeastern Federation of Women's Clubs. Last year we were incorporated under the laws 
of New Jersey and in May, 1908, we purchased a small house situated at 104 Harrison avenue, the lot being 25 feet by 108 feet. Our very efficient treasurer, who is a widow with her aged mother to care for, was installed as housekeeper. The house is a modest one, having only six rooms; these have been occupied ever since we opened. We hope to be able to enlarge the building soon, as we desire to be able to care for all or at least a large part of the girls and women who come to our city from various parts of the country seeking employment and of ten, unfortuuately, falling into bad hands.

From a membership of nine we have steadily grown until we number forty earnest workes.-Jersey City, N. J.

We have the E. L. Davis Club, which is a part of the Pennsylvania State Federation of Negro Women's Clubs. We have raised over two hundred dollars in the last two years for the Home for Destitute Negro Children, located at New Castle. We have assisted in paying the funeral expenses of a poor woman, given clothes to the poor, flowers to the hospital. We send three dollars each month to the home at New Castle towards the maintenance of the Home.-Johnstown, Pa.

The Mothers' Club was organized September, 1903, for the purpose of aiding struggling mothers. In May, 1904, we opened a day nursery-a small place of four rooms, for we were poor and few in number. We saw the great need for such a place for mothers-those who must go out to work-to leave their little ones to be cared for, instead of haring them roam the streets uncared for. We have struggled hard to carry on the work. The meetings are very helpful to all. We have very often a program, and topics for discussion which are usually Child Training, Housekeepiug, Village Improvement, or some race subject, or temperance.-Proridence, R. I.

We have been organized four years. During this time we have made donations to any and every needy person, regardless of denomination. We are laboring now to raise means to establish an Old Folk's Home, which we hope to be able to do in the near future. Our membership is fifty-nine, with seven officers. We meet twice during the month. Our treasury is maintained by the monthly dues paid by each member, together with donations given at the different mass meetings held by the club.

The preamble of the constitution is as follows:

"Whereas, a nation's standard is measured by that of its women, and seeing great need of improvement in the race in general: we the women of Jackson, State of Tennessee, being sensible of the great responsibility resting upon us as women, have organized ourselves under the name of a Woman's Club.

"We believe that in union or friendly co-operation in the work of "lifting as we climb, we can best elerate our homes and the race by developing ourselves along rarious lines, we do hereby adopt the following Constitution and By-Laws for the Woman's Club of Jackson, Tennessee."-Jackson, Tenn.

Different men, lawyers, doctors, ministers, also visiting men of note, address the club at each meeting; dues and other moneys are turned over to the church; we have sent barrels to different industrial schools in the South, and also make up baskets and boxes for one or two orphan asylums and Old Folk's Homes.St. Paul, Minn.

The first summer, or racation school to be maintained by any Woman's Club in the State was organized by the Koffee Klatsch in 1906. The children receired instruction in sewing, picture-framing and cooking. The smaller ones were kept interested in blackboard work, story telling, etc. These 


\section{Women's Clubs}

classes, with an average attendance of eighteen and twenty, were maintained for two years.

Aside from the general relief work, specific attention is given twice yearly to the Home for Aged and Infirm Colored People. During the early autumn a special day is given over to the club, at which a good program is arranged at one of the churches and a collection is lifted solely for the purpose of buying fuel for the Home. This is known as "Coal-fund day."

When the fruit season is at its best a day is set apart and known as "Canning day." The members of the club take the fruit and sugar out to the institution and put the fruit up for the winter. Over one hundred and fifty quarts have been put up by their exertions at different times. At various times money has been raised to assist in placing an inmate in the Home.

Miscellaneous relief work has included cases like the following: the purchase of fuel, groceries, and miscellaneous provisions; the distribution of clothing and shoes and medicine, also services of a physician; helping to purchase an invalid chair, and occasionally a special cluurch donation.

We feel that we have been wonderfully blessed in our endeavors, as no case reported to us during our existence has been passed over on account of lack of funds.

A committee of four ladies are delegated to visit the sick and bring reports of cases to be looked after.-Chicago, Ill.

The College Aid Society of Wilberforce, Ohio, have to their credit thirty years' support of aiding needy students. The Twentieth Century Club of Xenia, Ohio, has pursued a course of study of American and English literature, and fostered the kindergartens for colored children in Xenia, Ohio.

The women of St. Louis, Missouri, under the leadership of Mrs. M. L. Harrison, have completed seven years of successful work in caring for the St. Louis Colored Orphans' Home, which they founded May 19, 1901, at a cost of $\$ 6,700$. Mrs. Susan Paul Vashon, of St. Louis, has been successful in arousing the interest of a large number of mothers in forming mothers' clubs and holding mothers' meetings.

The colored women in Indianapolis have a club which has been interesting itself to secure opportunity for colored women to get work. Arrangements have now been made by which more than 150 colored women have secured work in one of the canning factories of that city, the managers having agreed to take only women and girls recommended by clubs.

The Harriet Tubman Club, of Boston, Mass., has been successfully conducting a Home for Working Girls on Holyoke street. This property is in a good part of the city and has sheltered a large number of women, giving them a good comfortable Christian home. Ruth Circle of King's Daughters of Boston has done much to assist in the charitable work of the city. The Woman's Era Club of the city of Boston has covered a wide field of work along literary, musical, and other lines. The Woman's Loyal Union, New Bedford, is engaged in the work of a Home for the Aged, irrespective of race or religion (see souvenir program and historical sketch). The Woman's Progressive Club of Worcestor, Mass., is also the founder of a Home for Aged People in that city.

Through the efforts of Judge Feagin and the work of an organization composed of the better class of Negro women in Birmingham, Ala., an industrial school has been started and to this eighteen little waifs have already been sent. During the past year these women have raised $\$ 2,000$, with which they purchased twenty-five acres of land near Montgomery, Ala. Upon this they have built a six-room cottage which now serves as a home for these eighteen 
little waifs. The superintendent chosen for this school is W. B. Tyrrell, a Negro of unusual ability and peculiar history. After being educated in the schools of his native State, Virginia, he was sent by a priest to a classical school in England to be trained for the Catholic priesthood. He was seven years in England, then was graduated from Bonn University in Germany and went as a missionary to Abyssinia. Failing health compelled him to return to this country. He has taken up the work for colored youth with great zeal.

The Yates Woman's Club of Cairo, Ill., recently pnrchased land on which to build a hospital. Within three years the club has raised more than $\$ 2,100$, paying in cash $\$ 900$ for their land and $\$ 1,200$ on a two-story brick building.

The Phyllis Wheatley Club, Chicago, Ill., has a Home for Working Girls and has been very successful in securing funds for the land and for buiding and maintaining the work; in fact, all of the clubs in Chicago, as well as in the State of Illinois, are all well organized and working along many lines for the uplifting of humanity.

The State of Texas is well organized. At the recent meeting of the State Federation, "The Mother's Part in Preventing Diseases" was discussed; also many pertinent ideas concerning the responsibllity which rests upon mothers to train their children in hygienic living; "What the washwomen have done for us as a race," was another subject presented. Special mention was made of the great work and influence of those great workers who have humbled themselves that their children might rise to higher plains of usefulness. In fact, the women of Texas are alive to the demands which the spirit of the times has placed upon colored womanhood.

The Woman's Industrial Club of Louisville, Kentucky, is a business, charitable and industrial club, quartered in a well-equipped twenty-room building on one of the most popular thoroughfares of the city. Various industries are carried on under its roof, and it has given impetus to the business life of the city of Louisrille.

From the millinery department have gone out scores of young women who are doing high-class work. Louisville has a large number of clubs, and the next biennial of the National Association of Colored Women is to be in the city, the guest of forty clubs of that city.

The White Rose Mission of New York city, organized about twelve years ago byMrs. Victoria Earle Matthews, has done much good work in that city. A large number of needy ones have found shelter within its doors and have been able to secure work of all kinds. This club has a committee to rneet the incoming steamers from the South and see that young women entering the city as strangers are directed to proper homes. Mrs. Frances Keyser, who has charge of the work, is the right woman in the right place.

The Dorcas Home Mission Society of Brooklyn, N. Y., which numbers two hundred good earnest working women under the leadership of Mrs. Alice Wiley, has done much to relieve the sick and distressed in that city.

Last year the clubs of Minnesota issued a State Federation calendar, which Was a most beautiful calendar of all the clubs, with the date of their organization, federation days, hours of meetings, their presidents and those in the National Association of Colored Women. It was a beautiful design and reflected much credit on the women of Minnesota.

A Mothers' Reception was held by the clubs of Colorado, fifty invitations on postal cards haring been issued for the same. "Tentilation and Sanitation," also "The Mother's Influence in the Home," were the subjects discussed, each 
telling of some of her experiences in her own home. The key note sounded by the mothers was, pure mothers for pure children; they advocated patience for the children, reasoning, and less whipping, thereby gaining their confidence and making them companionable.

The W. C. T. U. used to be strong among colored women and is still influential; it is, for instance, "a strong influence for good" in Dallas, Texas.

The King's Daughters and Sons have many colored circles:

In New York city there is a Circle which has done very earnest work, and also the Gould Circle, the Rest-Room Circle, the Aunt Jane Circle, Home for Aged Colored People,.St. John's Place, Brooklyn, also do splendid work.

In Toledo and in other Ohio cities the colored people have done some very fine work. In Michigan, also, the colored people have accomplished a great deal. There is a Circle of colored people in Frankfort, Kentucky.

There are, of course, other Circles, but, as I say, we cannot give you a complete list and can only indicate here and there some of the better known workers.

\section{Other reports follow:}

Our club, the Faithful Few Circle of the King's Daughters, belongs to the International Order of the King's Daughters. While we operate under their constitution and laws and labor for the same cause, we belong to the Missigsippi State Federation of Women's Clubs.

We have a membership of twenty-five persons, with about twelve active workers. Our work is confined to the unfortunate, "In His name." We use the Silver Cross Journal and keep in touch with the great Order throughout the world.

We are now attempting to build an "Old Folk's Home," with a nursery and a kind of headquarters for working girls, somewhat on the order of a rescue home.-Natehez, Miss.

We have the King's Daughters Society, which has been organized seventeen years. We have a membership of fity-two, and our work is to care for old people who can not help themselves. During the past year we gave as much as $\$ 68$ in money, and each week we make up baskets of food and clothing and send to the needy. We have also helped to bury a number of poor persons.-Austin, Tex

The following are the kinds of program rendered by these Women's Clubs:

Ohio State Federation, Dayton, O.

Subject: Light on the Work of the Ohio State Federation.

The Local Clubs.

Program

The Model Club.

The Ohio Federation, its Weak Points and How to Overcome Them.

Helpful Echoes from the World's Fair and Club Life in Missouri.

Hints on Club Literature.

Our Ohildren. Shall the Ohio Federation form Clubs among its Ohlldren?

Race Pride as Manifested in Olub Life.

The Entertaining Hostess, and Appropriate Decorations and Souvenirs or Favors.

To What Extent Should our Federation be Public-Spirited ? Have we a Voice in the School, the Republic, the Nation? 
The Wheel of Progress, Cincinnati, $O$.

\title{
Philanthropical and Economical Department
}

\author{
SECOND TUESDAY
}

November 14: Original poem, "The Forest." Music. Discussion, "Misplaced Oharity."

December 12: "What is the Greatest Evil that Retards the Oommercial Progress of the Negro?" Music. Industrial Work.

January 9: Discussion, "The Best Education for our Girls." Music. Industrial Work.

February 13: Paper, "Should Social Games be Enconraged in the Home, and to What Extent?" Music. Industrial Work.

March 13: Discussion, "What Can the Club Woman Do to Raise the Inteilectaal Status of our Young Men?" Music. Industrial Work.

April 10: "Influence of Aesthetic Decoration in the Home." Music. Industrial Work.

May 8: "Reverence for Holy Things." Music. Industrial Work.

June 12: "The Attitude of the Club Woman Toward Her Less Fortunate Sisters." Music. Industrial Work.

July 10: "Development of Domestic Economy." Music. Industrial Work.

August 14: "Checks to Eril Influences of Environment." Music. Industrial Work. "Duties of a Good House-wife." Music. Industrial Work.

September 11: "Economy and Taste in Dress." Music. Industrial Work.

October 9: Annual Reports. Election of Offleers.

\section{Literary and Musical Department}

FOURTH TUESDAY

Norember 28: Queries and Current Events. Instrumental Music. Lecture, "A Trip to sicily." Song.

December 26: Queries and Curlent Eveñts. Paper, "Negro Writers and Their Best Productions." Music.

January 28: Queries and Ourrent Events. Lecture, "Development of Political Economy." Vocal Music.

February 27: Queries and Current Events. Paper, "Anti-Slavery Heroes of the Nineteenth Century." Instrumental Music.

March 27: Discussion, "How Can We Dignify the 'Jim Orow' Oar?" Paper, "The Most Potent Influences Tending Toward the Eradication of Color Prejudice." Bong.

April 24: Queries and Current Events. Instrumental Music. Paper-Prose Fiction, "Ramona." Music.

May 22: Queries and Current Events. Paper, "Oharacteristics of the Poetical Triad.' Instrumental Music.

June 26: Queries and Current Erents. Paper, "The Story of Toussaint L'Ouverture." Music.

July 24: Queries and Current Erents. Paper, "Harriet Beecher Stowe and Her Writings." Music.

August 28: Queries and Current Erents. Paper, "Natural Curiosities of Our Country." Music.

September 25: Cullings from Vacation Experiences. Lecture, "The Great R日ligions of the World." Music.

October 23: Greetings from Distant Members. "The Club Outlook." Song. 
Section 11. Old Folk's Homes. The most characteristic Negro charity is the Home for Old People. Nothing appealed from the earliest days more strongly to the freedmen than the care for the old people.

In slavery days the old were, in many cases, carefully taken care of by the masters, especially in cities and towns and on the home plantations, but in numberless other cases, particularly on the great absentee plantations of the Black Belt, the old and decrepit were shamefully treated and neglected. The breaking up of families in slavery by sale and during the war and Reconstruction times, greatly aggravated the sufferings of the old, while the loosened family ties, due to the slave system, left in post-bellum times numbers of neglected old folk. Even loose family ties, however, were not able to overcome the native African reverence for parents, and before the war began Old Folk's Homes for: Negroes had begun to be established, some by Negroes themselves, others by their friends.

The chief Homes now existing are noted below:

The Women's Twentieth Century Club of New Haven, Conn., was organized March 18, 1900, at the residence of Mrs. J.W. Stewart, 65 Edgewood, with a membership of nineteen.

At first we met for the study of race literature and to become better acquainted with the history and life-work of our celebrated men and women. The idea of charitable work was an after consideration.

Some of our members, in making sick calls, had visited the Hannah Gray Home and our attention had been called to the condition of the same.

Right here it would be well to state that this property, located at $158 \mathrm{Dix}$ well avenue, was formerly the home of a colored woman by the name of Miss Hannah Gray. She died in the early sixties and left the property in the hands of white trustees for the use of aged colored females. From what we have been able to learn, it was the first piece of trust property left for a home in the city. Unfortunately, Miss Gray had little or no money to leave as an income, to care for the home, and the inmates paid a small sum for the use of the rooms.

The club in 1903 appointed a committee to wait on Lawyer Henry White, the only living trustee, and found that the back taxes amounted to two hundred dollars, and the property would soon be disposed of to pay the same. We informed Mr. White of our willingness to try to save the property. At our request three colored trustees were appointed. The back taxes were abated and by appeals we have been successful in having them abated each year. Since the club took control we have had the house painted inside and out, walls and ceilings scraped, wood and coal put in each year, and in many ways we have been the mainstay of the old ladies.

Since 1903 four of our old friends have died, and the club assumed all responsibility for burial expenses.

At the present time we have five in the home; two being dependent upon us. At the holiday season they have been given regular holiday dinners, and the public schools have at Thanksgiving sent money and vegetables. Through the kindness of a white friend last year the five enjoyed a Christmas tree and each received a small gift of money.

For nearly two years we have employed a woman to go to the home daily and look after things. 
The club annually elects a board of directors to look after the affairs of the home and report same to club. Our other officers look after the program, club business, finances, etc.

We have now a membership of over fifty. We meet weekly and have a program every Wednesday, except the last in the month; this we devote to business.

We are now making an appeal for funds for a new building, and have already in hand money for a new fence; circulars are out for donation day and two days' fair, June 2nd and 3rd.-New Haven, Conn.

St. Monica's Home is an old and well-known charity of Boston, Mass., supported in part by Negroes.

Home for Aged Men, Springfield, Mass., founded by Primus Mason for all races (cf. p. 38).

Home of the Aged, New Bedford, Mass.

The idea of having the New Bedford Home for the Aged was planned nearly twelve years ago by Miss Elizabeth C. Carter, who had been accustomed to making friendly visits to several aged people in this city, and who was previously interested in the Home for Aged People in Brooklyn, N. Y.

In this way she knew many aged ones; knew their needs, sufferings and joys. Here and there many were being provided for by private bounty. Miss Carter came in contact with several cases of this kind, and it caused her to study how something could be done to let the old people really get the benefit of the money that was being paid regularly for them, yet some of them too feeble to care for themselves properly.

So, after studying the question from every point of view, she planned the work, relying upon the co-operation of the persons supporting the old people to secure a pleasant house, furnish it invitingly, and gather the old people into it, with the hope of making it in the truest and sweetest sense a home for them.

The Woman's Loyal Union indorsed the idea and voted to unite their efforts for the maintenance of the Home. After trying to secure several houses for the work, the house at the corner of Cedar and Mill streets was secured by Miss Carter paying one hundred and five dollars of her personal money for six months' rent in advance, the society at this time having no money in its treasury.

The members of the union took books and solicited money, furniture and groceries, with the result that everything in the house was donated.

The Home was opened to the public March 25, 1897, and, like all other charitable work, it has had its "toils and conflicts," but by generous contributions it has continued. In 1898 a building fund committee was formed. After remaining in the house at the colner of Mill and Cedar streets nearly two years the work was moved to 121 Cedar street, which the society has rented until moving into its present building. January 14, 1902, the organization was incorporated under the general laws of the State of Massachusetts. In December of the same year the first large gif $-\$ 500$, which was continued until last year-was received from a friend for the current expenses.

In 1904 one thousand dollars was received from the estate of Robert C. Billings, of Boston, and the same year land at the corner of Chancery and West Middle streets purchased. In 1904, by the terms of the will of the late Sarah E. Potter, ten thousand dollars and a part of the residue of the estate of Mrs. Potter was left to the Home. It is by this beneficent gift that the present building has been erected. Ground was broken in August, 1907, during 
Old Home Week. The estimated cost of the building was $\$ 8,625$, but with some necessary additions the building has cost $\$ 9,000$. It contains twenty-one rooms. The furnishing cost between one and two thousand dollars, all of which is paid for at present. They have invested in stock $\$ 11,780$, in bonds $\$ 12,951.68$, cash $\$ 8,895.06$; total amount, $\$ 33,626.74$.

The future efforts of the management will be to secure funds for the current expenses; also an endowment fund, so that the work may become self-supporting.

During the work of eleven years nearly all of the charitable organizations of the city, also several churches as well as individuals, have assisted in some way.

Home for Aged Colored Women, Providence, R. I.

The Lincoln Hospital and Home, New York, N. Y., is an old charity supported by whites mainly. Cares for old people.

Home for the Aged, Brooklyn, N. Y.

Home for Aged and Incurable, Atlantic City, N.J.

Dr. Fayerman, seeing the need of such an institution occasioned by the peculiar conditions of Atlantic City, some years ago worked very hard for the establishment of it. As most of the cottagers there fill their houses.with lodgers, a sick person, or aged one, would necessarily receive scant attention.

Colored Aged Home Association, Irvington, N. J.:

This Home was opened in 1895 at Coe's Place, Newark, where we paid rent for ten years. The association then thought it time for them to buy a place, so we moved to Ivington in 1905 . We have a nice place which cost $\$ 4,500$. We paid down $\$ 2,000$, and are now in the building and loan association and pay $\$ 32$ a month and we are doing the best we can. Since we opened we have had about 42 inmates, and would have had more if we could have taken them for nothing, but you know it takes money to run a place of this kind. In such a work the laborers are few, still we are doing the best we can and at the last meeting twenty-five names were enrolled, which means something. We have very little income. There are fifteen inmates now.

Annual Report for Year ending December 31, 1908 RECEIPTS

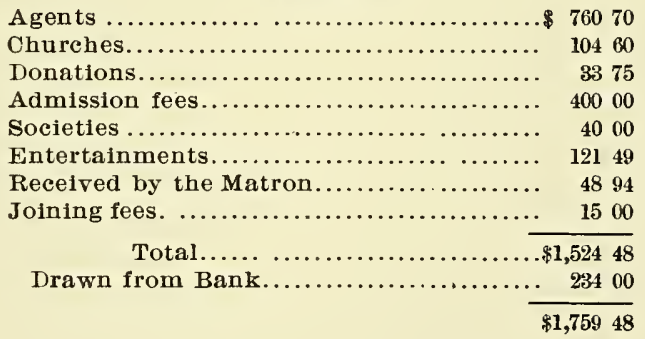


DISBURSEMENTS

\begin{tabular}{|c|c|}
\hline ( & \\
\hline Insurance $\ldots \ldots \ldots \ldots \ldots \ldots \ldots \ldots \ldots \ldots \ldots \ldots \ldots . \ldots \ldots$ & 6000 \\
\hline 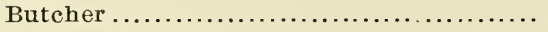 & 24000 \\
\hline 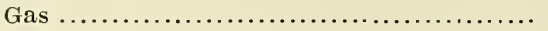 & \\
\hline r $\ldots \ldots \ldots \ldots \ldots \ldots$ & 21 \\
\hline elephone............................. & 562 \\
\hline oal........................................ & 14750 \\
\hline help.............................. & 2100 \\
\hline$r$ r & 37 \\
\hline ag and Loan Association ........... & 38400 \\
\hline 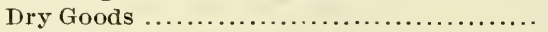 & 825 \\
\hline $\ldots \ldots \ldots \ldots \ldots \ldots \ldots \ldots \ldots \ldots \ldots \ldots \ldots \ldots \ldots$ & 1500 \\
\hline$\ldots \ldots \ldots \ldots \ldots \ldots \ldots \ldots \ldots \ldots \ldots \ldots \ldots$ & 21100 \\
\hline als $\ldots \ldots \ldots \ldots \ldots \ldots \ldots \ldots \ldots \ldots \ldots \ldots \ldots$ & 6616 \\
\hline 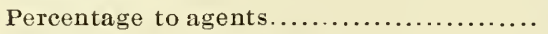 & 16725 \\
\hline 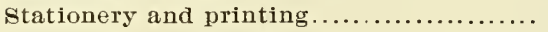 & 800 \\
\hline . n w & 3000 \\
\hline & \\
\hline d................... & \\
\hline Sank to date........ & \\
\hline
\end{tabular}

Home for Aged and Infirm Colored Persons, Philadelphia, Pa., was founded by Stephen Smith and organized September 14, 1864. The Home has sheltered seren hundred and serenty inmates and had, in 1908, one hundred and forty inmates. The income from the estate of Smith amounts to about $\$ 3,760$ annually, representing a capital of nearly $\$ 100,000$. The total income is $\$ 21,000$ and the property is worth $\$ 400,000$. The home is controlled by twenty-eight trustees, of whom fire are colored.

Home for Aged Colored Men and Women, Philadelphia, Pa.

Colored Masonic Home and Orphanage, Linglestown, Pa.

The Grand Lodge of Colored Free and Accepted Masons of this State has recently formed a corporation known as the "Trustees of the Colored Masonic Home and Orphanage of Pennsylvania," and has purchased near Linglestown, nine miles from Harrisburg, a farm of some sixty or more acres for which they paid $\$, 500$.

The purpose of this corporation and the farm which they have purchased, is to maintain a home for aged and indigent Masons, their widows and orphans.

Home for Aged and Infirm Colored Women, Pittsburgh, Pa., is "said to be the best in the country conducted entirely by our people."

The Sarah Ann White Home, Wilmington, Del.

The will of Sarah Ann White said:

"I give, derise and bequeath to the Rev. Edward H. Chippey in trust for a home for the colored aged women, all of my property of whaterer kind, real, or personal, or mixed, wherever it may be found, and that as soon as an institution is incorporated that he may make orer said property to the incorporation to be theirs and their successors so long as they shall continue to carry out this, my last will and testament.

"It is my desire that the Rer. Edward H. Chippey shall organize an association to be known by the name and title of the Sarah A. White Association, composed of male members and fernale members, with a Board of not less than five Trustees nor more than seren male members of African descent, said members shall compose the incorporation (corporators)." 
The faithful adherence by the executor and the Association to the program laid down by this public-spirited woman was the occasion of constant remark on the day the Annex was dedicated. The failure on the part of the heirs after a long contest to break the will left the executor and his associates free to develop the provisions of the "trust."

May 4th, 1896, found the institution incorporated under the name of the Sarah Ann White Home for the Aged and Infirm Colored Persons, and conducting a Home in the old homestead house, which soon became crowded and necessitated the building of the annex at a cost of four thousand dollars completed with modern improvements.

The corporation is absolutely without endowment, and receiving no aid from the State; these facts are eloquent evidence of the magnitude of the struggle which has maintained this institution, housing, feeding, clothing, nursing, and providing for the many wants of as many as twenty old people at a time, with recourse to nothing but public charity. It is this condition of things which impels us to new endeavor to pay off the mortgage and lay the basis of permanent endowment.

Aged Men and Women's Home (Lee street), Baltimore, Md. Property $\$ 3,000$. Inmates, 16 . State aid, $\$ 250$.

Bethel Old Folk's Home, Baltimore, Md. Property, $\$ 10,000$. Inmates, 16.

The Stoddard Baptist Home, District of Columbia.

Some ten or twelve years ago Mrs. Maria Stoddard, a white woman, saw fit to set apart a small portion of ground in a very fashionable part of Washington, D. C., for a Baptist Home. But the gift was accompanied with conditions and limitatious, which caused it to be of little service for a long while. Then the city cut off a portion of the lot to widen and improve a public street. 'This so reduced the size of the place that it was too small for such a home as the Baptists of the District of Columbia desired to have. Moreover, the heirs of Mrs. Stoddard came forward at this juncture and claimed both the money, which the District was about to pay for what it had taken for public use, and the remainder of the property. Consequently, the matter was thrown into court, and the heirs agreed with the trustees of the property, the court consenting, to sell the property, then divide all money coming from the disposition of any and all parts of the gift as follows, after deducting all legal and court expenses : to the heirs of Mrs. Stoddard $40 \%$, to trustees of the Home $60 \%$. It was further provided, that the trustees of the Home should invest their portion of the money in property elsewhere, for a Baptist Home, and so carry out the desire and intention of Mrs. Maria Stoddard in making the gift. Accordingly a tract of land, consisting of four and a half acres with a ten-room house on the same, was purchased about May 20, 1901, and a few months later put in proper condition and opened to Baptist ministers, their widows and orphans, and such other persons as the trustees see fit to admit. June 15, 1901, five and a half acres more were purchased by the trustees of the Baptist Home, giving them in all a total of ten acres. For this addition the sum of $\$ 2,750$ was paid.

The Home is the property of the Baptist Ministers' Union of the District of Columbia, and is held in trust for the purpose and persons to which it is set apart by fifteen trustees who are appointed by the Baptist Ministers' Union of the District of Columbia.

The institution is situated on Hamilton Road, in the southeastern section of District of Columbia. At present there are ten inmates in the Home, four men and six women. 
The management of the Home is in the hands of a body of women, consisting of ten delegates from each Baptist church in the District of Columbia and vicinity.

The property of the Home is free of debt, but the struggle to maintain the Home in a becoming manner and pay the expenses of every kind arising from its care, gives the management daily concern. It requires about one hundred and ten dollars monthly to meet all the requirements of the Home and its management.

I am not in a position to give you any exact statement as to the amount of money which has been raised for the Home since it began. The truth is we are mere learners in the conduct of work of this kind. The churches have their special work of many kinds, and are slow to take hold of this, but the future is sure, under God.

Old Folk's Home, Richmond, Va. Conducted by the Afro-American Emancipation Association.

Negro Baptists' Old Folk's Home, Richmond, Ta.

The Negro Baptist Old Folk's Home, West Baker street, is the property of the Negro Baptist churches of Richmond and vicinity, and supported by the same with the aid of white and colored friends. Rev.R. V.Peyton is president and his church does much for its support.

Old Folk's Home, Westham, Ta.

At Westham, Va., the True Reformers support not only a home for the aged but also one for the orphans. This institution is in excellent condition and the inmates, old and young, are being taken from all parts of the country.

Old Folk's Home, Portsmouth, Va.

The Old Folk's Home at Portsmouth is about four years old. It is supported entirely by Negroes. It was their first intention to locate the home in the suburbs of the city, where they purchased two acres of land. Since then they purchased a plot in the eity at a cost of $\$ 4,000$. At present there are no inmates, as the promoters want to get the home paid for before they admit any.

Old Folk's Home, Hampton, Ta.

The Old Folk's Home at Hampton is a very interesting institution. It was organized in May, 1897, under the auspices of a society of women called "Tents." The head of the Order was the first to suggest that the Order have a home where the orphan children and the disabled sisters of the Tents might be cared for. She gave the ground and the sisters gave what they could to build and furnish the home.

This home is supported by contributions from the sisters, and no sister of the Order is allowed to solicit aid from the public. Last year it cost a fraction orer $\$ 500$ to care for the home. Since its organization in 1897 at no time has anything been bought on credit. This society not only supports its home but aids in other philanthropic work.

The home is controlled by a board of directors consisting of nine sisters of the Order. At present there are seven inmates.

Old Folk's Home, Norfolk, V'a.

At Norfolk there is an Old Folk's Home, which was organized in 1894 . Up to the present time it has cared for forty-two persons. Last year the expenses were $\$ 3 s s$, one-half of which was contributed by Negroes. At present the home has but three inmates.

Old Folk's Home, Gloucester, Va.

There is in Gloucester, Va., an Old Folk's Home, which was established in 


\section{Old Folk's Homes}

1907. It has twenty acres of land. The main building is not yet completed, but on June 3,1909 , there was a special rally to raise money for its completion. So far, the home has cost $\$ 890$, all of which was raised by the Negro women of Gloucester county.

Old Folk's Home, Alexandria, Va.-Non-sectarian and supported by voluntary contributions, with some city aid. There are from six to twelve inmates. It owns no real estate.

Tent Sisters' Old Folk's Home, Raleigh, N. C.

This is, perhaps, the;most interesting experiment in the country. The secretary writes:

A few years ago I opened a school, of a business nature, but soon realized the class who really needed aid did not reach that standard. This school 1 closed, and a work has been quietly going on that I know God is well pleased with, for we daily see $\mathrm{H}$ is blessings.

By becoming a member of four secret orders-you know the masses like such-I am in sympathetic touch with a great number, and can visit them in numbers. Through some of the women's earnest work, about two years ago we began to fix and fit a home for old people who are in a suffering condition. Since that time we have had nine inmates. Some of these came from neighboring towns. We have also had one death. None of these inmates have given us five cents for expenses.

This work is done through our club known as Tent Sisters in North Carolina.

Two hundred and fifty working women pledge one pound of food a month and at the least twenty-five cents per year in cash and more when dire necessity demands.

We borrowed from the building and loan association $\$ 200$. The donations to this work are as follows:

Raleigh, N.C.-Furniture, bedding, erockery, clothes, and twenty-five dollars.

Cary, N. C.-Food, clothing, and ten dollars.

Apex, N. C.-Food, clothing, and seven dollars.

Holly Spring, N. C.-Food, clothing, and eight dollars.

Willow Spring, N. C.-Food and five dollars.

Durham, N. C.-Nine dollars.

Johnson, N. C.-Three dollars.

Wake Forest, N. C.-Two dollars.

Individuals, thirteen dollars and seventy-five cents; also, we have entertainments to meet many expenses.

\section{DISBURSEMENTS}

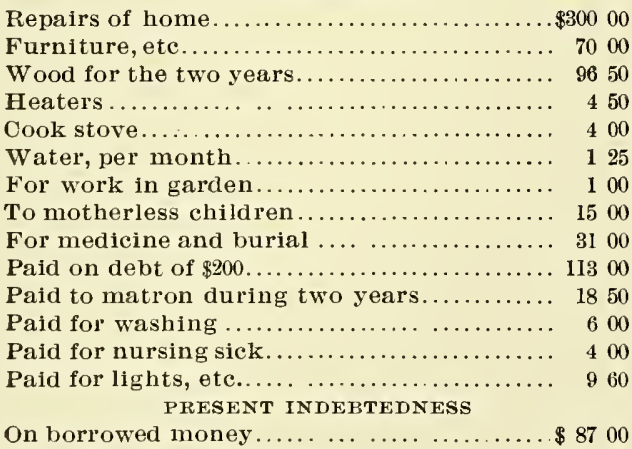

For medicine and burial .............. 2075 
The matron has no stated salary, but we are obligated to pay her more for past services.

Mrs. Lucy Fikes has given her life to this work without a penny from us. She is a woman who has to earn her bread daily. I, the secretary, being busy in different working quarters, have no itemized account of everything done but this will give you an insight of the work.

About one hundred of the two hundred and fifty persons helping are more than sixty years of age. Some are feeble, yet they help carry on this work with their means.

One who knows the work but is unconnected with it says:

They are all Negroes. It is run by the poor working class of Negroes; has no endowment, and the inmates come though they have not a penny to help them. People make bed clothes for them. They need money to help pay someone to care for them. They have one wooden building which was once known as Business School and is owned by Miss Sallie A. Upperman. She has kindly given it to the people for the purpose of charitable work. She is trying to help the boys and girls, the women and men, who walk the street because they do not know how to do what is required of them to make an honest living. I believe that God will help her. I shall do all I can in this noble work. She needs encouragement.

The Centenary Church Home of Charleston, S. C., is suppored by a Negro church.

Ashley River Asylum, Charleston, S. C.:

Is an institution entirely supported by the city government for aged colored people, male and female. The institution is excellently conducted by very competent officers (colored) and the inmates receive the best treatment in food, clothing, and the ordinary comforts of life.

Masonic Home, Columbus, Ga.

Carter's Old Folk's Home, Atlanta, Ga.

Old Folk's Home, Augusta, Ga.

Erergreen Old Folk's Home, Savannah, Ga.:

The Erergreen Old Folk's Home was organized April 7, 1908. I am very sorry that I am not able to speak of it as I would like, but I am thankful to the Lord for what $\mathrm{He}$ has done and is still doing. It was incorporated May 2., 1909 .

Tre have nine inmates and could have had one hundred and nine, but on account of the way in which we had to provide for them we decided we wonld go slowly until we could do better.

Rescue Home for Orphans and Old Folks, Jacksonville, Fla.

The Colored Old Folks and Orphans' Home, of Mobile, Ala., was organized in 187l. One piece of property was bought and lost, and a second piece bought for $\$ 4,000$ casl. It contains two acres of land, with fourteen pecan trees. The college has nine rooms, running water, and $\$ 120$ a year is earned from pecans and pears. They have a cow and chickens, and own other real estate.

The Priscilla Brown Mercy Home, Selma, Ala.:

A charitable organization of the city of Selma was organized October 9, 1902, irrespective of denomination. They were at first a committee auxiliary to the $U^{\top}$. A. Charity Association which after a few meetings drifted into obscurity, and the Daughters of Mercy, seeing the good work to be done and 
having already begun, became an incorporated body. The first donation given was two lots of land nearly paid for by Sister Priscilla Brown, a woman well known for her good deeds and charitable works, and her devout Christian spirit, and for whom our home is named. This band begun by seven women afterward grew to nine and now to forty-five, all mostly volun teers.

Our meeting days are the second and fourth Thursdays in each month, at the home of the president. We have now an honorary board of trustees composed of all of the ministers of the different denominations, and their successors, with Principal R.B. Hudson as chairman. We have not space to place before the public the many needy poor we have relieved with clothing, food, medicine, coal, shoes, books and tuition for orphans, during our organization. Each year at Thanksgiving the city school children give to us a great amount of food to be distributed among the poor.

The Priscilla Brown Mercy Home was opened and dedicated last October. We now have a matron and four inmates in the home. We are, however, prepared to accommodate comfortably about twelve. Our means are limited, and one of our rules for entrance is that all persons coming to us must be recommended by the pastor and officers of some church or officers of some society. Those organizations sending to us inmates partially support them. Our standard age for receiving persons is sixty years of age and upward.

The house is furnished throughout with single iron beds. The sanitary conditions are good. The property is valued at $\$ 2,500$.

Old Folk's Home, Birmingham, Ala.

The Lafon's Home of the Holy Family, New Orleans, La.

The Lafon's Home of the Holy Family, corner Tonti and Hospital streets, is largely the gift of the late Thomy Lafon, who left over $\$ 100,000$ for this institution. Before he died he also gave them their chapel. This home has 71 inmates and is the home for the old indigents. The city contributes $\$ 30$ per month to this home.

The Lafou's Old Folk's Home, New Orleans, La.

The Lafon's Old Folk's Home is operated by the Protestant people. The late Thomy Lafon left $\$ 11,000$ and Aristide Marie left $\$ 1,000$ for this home. The city contributes $\$ 120$ towards the support of this institution. For maintenance the institution depends almost wholly upon the colored Methodist and Congregational churches of this city. It has on an average about 25 to 30 in mates, both male and female, old indigents.

'The Widow's Faith Home for Colored Destitutes, New Orleans, La.

The Faith Home, corner Robert and Pitt streets, is maintained and operated by the colored Baptist churches of this city, and is also aided to a small extent by the city. It is now taking care of 18 colored women, some of whom are over a hundred years old.

The Liner's Harrest Home, New Orleans, La.

The Liner's Harvest Home is for men, women and children. It was established over twenty years ago by the late Edward Liner, who gave the lots and building. The institution is in charge of Mrs. Fanny Taylor, who is aided by an organization of charitably disposed colored persons. There are now 16 inmates, five of whom are men, six women and five children. It depends entirely upon subscriptions for its maintenance and support. The property is ralued at $\$ 6,000$.

Woman's Home Mission Society Home, Baton Rouge, La. Conducted by Baptist women. 
M. W. Gibbs Colored Old Ladies' Home, Little Rock, Ark.

Our work at present is the furnishing of one room at the Old Ladies' Home. A new building is being erected by the citizens of our city, and the different clubs are furnishing it. The site for the building was given by Judge M. W. Gibbs, and the home is named for him.

St. James Old Folk's Home, Louisville, Ky.

The St. James Old Folk's Home was founded in 1887, or thereabouts; flourished a few years, got on the toboggan and went to the bottom in 1893 . A 5ounger set, together with two or three of the old managers, reorganized the Society of St. James and under the leadership of Miss N. L. Frye undertook the purchase of the present $\$ 10,000$ property at a set-up price of $\$ 3,500$ on a five years' basis at six per cent. By paying in advance and saving, or discounting the interest, we bought it for a little more than $\$ 2,900$. The lot is 200 feet by 200 feet, with a seven-room frame dwelling. We have erected a handsome little chapel seating about 150 comfortably. There are all necessary outbuildings-stables, chicken-houses, etc.

The institution is owned and controlled exclusirely by colored people, and we owe not a cent on it. It is the only institution of its kind in the city that is strictly and unconditionally owned by colored people.

Widows and Orphans' Home, Jackson, Miss.

Old Ladies and Orphans' Home, Memphis, Tenn.

Old Folks and Orphans' Home, Memphis, Tenn. Property, $\$ 15,000$.

Masonic Widows and Orphans' Home, Nashville, Tenn.; property, $\$ 7,000$.

Old Folks and Orphans' Home, Kansas City, Mo.

About fifteen years ago a colored man, Samuel Eason, undertook to care for a number of aged people in a frame dwelling at 1308 Vine street. This was the beginning of what is now known as the Old Folks and Orphans' Home in Kansas City, Mo.

Mr. Eason was soon assisted by some good women from the different churches, a number joining them after a charter was obtained in 1896.

As time went on Mr. Eason withdrew from the association, which was composed of women assisted by seven trustees.

A building with a lot of fifty feet was purchased at 2446 Michigan avenue where the present home is yet located. The cost, which was $\$ 2,500$, was paid by the efforts of the association and the Codaya Circle (a literary club).

A building permit has just been granted to the association to erect a $\$ 4,000$ home on the present site. The association has been enabled to do this by the generosity of Mr. T. Benoist, who left to the Old Folk's Home Association $\$ 4,000$ in his will.

The old building will be pushed to the rear of the lot and the new home of brick will be erected in front.

The Home is supported entirely by roluntary subscriptions. During the past two years over forty old people and children have been cared for. Good homes are obtained for the children as fast as possible. Orer one thousand dollar's were giren to maintain the Home during the past year.

The association is composed of fifty influential women and seven men trustees.

The erection of the new Home will double the capacity of the present quarter's. 
Old Folk's Home, St. Louis, Mo. Maintained by the Central Baptist Church.

Old Folk's Home, St. Louis, Mo. Maintained by the Wednesday Afternoon Serving Club.

Taborian Home for Aged and Indigent Members, Topeka, Kan. For members of the Knights of 'Tabor, a secret organization.

Home for Aged and Infirm Colored People, Chicago, Ill.

Probably no institution in Chicago is more entitled to the consideration of the charitably inclined than is the Home for Aged and Infirm Colored People, now located at No. 610 Garfield Boulevard (West Fifty-Fifth street).

These old people, from no fault of their own, were forced to spend the best years of their lives in the service of others, deprived of the right to make a home for themselves, or to provide for the coming of old age and infirmities. Bred in ignorance and reared in oppression, it is but a common act of humanity that they be allowed to spend their declining years in an atmosphere more hospitable and congenial than is usually accorded in a county alms-house.

Several years ago the present superintendent, Mrs. Gabriella Smith, gathered together several of these homeless old people and, at great personal sacrifice, cared for them as best she could. She succeeded in interesting a number of her race in the work to the end that on the second day of April, 1898, an association bearing the name as above was incorporated and the home permanently established.

The first to come to the assistance of the Home in a substantial way was Mrs. Bena Morrison, to whose splendid philanthropy the organization is indebted for the gift of the property now occupied as a home, together with its furnishings; also the piece of property known as No. 620 Fifty-seventh street, as the nucleus of an endowment fund. She has also made donations of cash which more fully appear in the treasurer's report. This gracious act on the part of Mrs. Morrison has made it possible to comfortably house and provide for fifteen old men and women during the past pear.

The secretary's report gives a list of other donations received by the home for which the board of directors desire to make acknowledgement.

Too much ean not be said concerning the economical management of the Home during the recent year. The report of the treasurer shows that $\$ 1,147.95$ passed through his hands and that the deficit for the year amounts to $\$ 61.52$. While this does not include donations of food, etc., yet it is remarkable that so much could be done for so little money.

The superintendent, Mrs. Gabriella Smith, served the year without any compensation whatever; such heroic self-sacrifice is rare, and while the board of directors make grateful acknowledgement, they can but feel humiliated; such sacrifices should not be demanded of her, nor is it fair to accept them. She is a working-woman, with no means other than what she daily earns.

The Volunteer Workers for this home were organized in 1904 and give an annual bazaar. They have installed a steam-heating plant, and raised $\$ 1,000$ in 1909 .

Lincoln Old Folks and Orphans' Home, Springfield, Ill.

Green Memorial Home for the Aged and Infirm, Evansville, Ind.

It is yet in its infancy, but promises to be of much benefit to those whom it is intended to help. 
Alpha Home Association, Indianapolis, Ind. For aged colored people. Phillis Wheatley Home, Detroit, Mich.

The Labor of Love Circle was organized on February 26, 1907, and confirmed March 5, 1907. Its main work is in the interests of a charity and maintenance of the inmates of The Phillis Wheatley Home, an organization for old and infirm colored ladies.

The value of real estate on which the Phillis Wheatley Home is lozated is estimated at $\$ 7,000$, and accommodates twelve inmates, and is always taxed to its capacity.

Home for Aged Colored People, Cleveland, 0 .

Mrs. Eliza Bryant, one of our oldest and most highly respected citizens (now deceased), was impressed with the thought of establishing a home for worthy aged colored people of this city. In July, 1893, Mirs. Bryant expressed the thought to a few friends, and this led to a call through the colored churches to women to meet for the purpose of forming an organization to devise plans for the accomplishment of the work. At a preliminary meeting nothing more was done than to get the work before the people. After a few meetings the women formed themselves into a permanent organization, the condition of membership being the payment of one dollar each year.

The work mored on encouragingly the first year, and at the expiration of two jears, by means of membership fees, socials and entertainments the faithful few in the organization had in the bank \$407.85. A constitution and by-laws were adopted and the home was incorporated under the name of "The Cleveland Home for Aged Colored People," September 1, 1896.

After these two years of earnest work and much sacrifice on the part of the few that faithfully stood by the work of establishing the home, a small but comfortable structure was opened for inspection and reception September 2 , 1897, at 284 Giddings avenue. The attendance was large and the daily papers commented favorably upon the project. The original cost of the Giddings avenue home was $\$ 2,000$. September 9,1896 , the fir'st payment of $\$ 400$ was made, learing a balance of $\$ 1,600$ to be paid in fire notes.

Through the efforts of $\mathrm{Ar}$. Welcome T. Blue, the property at 186 Osborn street, containing eleren rooms and all improrements, was purchased. One thousand dollars was paid on this property as a down payment and the house thoroughly renorated in hope that the inmates might eat their Thanksgiving dinner at their new home. But this was not to be, for on Monday morning, Norember 25,1901 , the house was burned by an incendiary. This was a dreadful blow, but the earnest workers had the Home rebuilt and in such a manner as to make it more suitable for an institution of its kind, and the inmates were mored into it the first week of March, 1902

Mrs. Mina Harris, present secretary of the Home, gives the following statement of the year ending 1907. Total money received from the Men's Auxiliary, Board of Lady Managers, donation, entertainments and dues $\$ 759.4$, from Admission Committee $\$ 450.00$, making a total of $\$ 1,209.44$. Total expenditures $\$ \$ 4.57$, leaving a balance at the beginning of $1908, \$ 364.87$. The report for $190 \mathrm{~s}$ up to September 1st, is as follows: Receired from all sources $\$ 76$ S.74, total amount on hand $\$ 1,133.61$; total expenditures $\$ 969.92$, leaving a balance in treasury September 1,1905 , of $\$ 163.69$.

Old Folk's Home, Columbus, O.

Crawford's Old Folk's Home, Cincinnati, O. Property, $\$ 25,000$.

Home for Aged Colored Women, Cincinnati, O. 
Iowa Home for Aged and Orphans, Des Moines, Ia.

Home for Destitute Children and Aged Persons, San Antonio, Texas.

Beside the 61 homes mentioned above there are many others, while numbers are being started, as, e. g., in Anniston, Ala. :

The colored women have started a fund to build a home for old women and orphaned children. Quite a good deal has been collected. They hope to start this home very soon.

These efforts are of all degrees of efficiency and betterment, and receive considerable contribution from whites.

Section 12. Orphanages. Next to homes for the aged the Negroes have felt the need of orphanages and refuges for children. Of the homes mentioned above many also receive children, notably those at New Orleans, La., Kansas City, Mo., Springfield, Ill., Des Moines, Ia., San Antonio, Tex., Jackson, Miss., Memphis, Tenn., Jacksonville, Fla., and Linglestown, Pa.

The care of destitute children of freedmen and refugees especially appeals to the white friends of the Negroes. In cities like New York and Philadelphia there were, before the war, many such eharities. Numbers of these still survive, especially in Philadelphia.

The Home for Destitute Colored Children, 541 Berks street, was founded in 1855 and has forty young children.

The Shelter for Colored Orphans, Forty-fourth and Wallace streets, was founded about 1836 and has eighty-four children.

Each institution appears very cold and business-like, and seems to regard their chief function to be the training of servants. One report says:

Besides our usual visiting we have full written reports during the winter from the families in which our children are placed and thus keep in touch at all times with their welfare. It is always interesting to watch the development of the children, and we are often surprised to see how useful and dependable they become. There is an old saying: "Good mistress-good maid," and it is often so with these children, when they have conscientious, painstaking caretakers the children grow naturally into good habits.

Other institutions, like the House of the Holy Child, seem a little more human:

The object of this House is to provide a happy Christian home, permanent or temporary, for Colored Children of any age, who have been deprived by death, sickness or other adversity of a home with their relations. The House has the sanction of the Bishop of the Diocese, but has no connection with any parish, no endowment, no wealthy patron, and therefore asks for gifts, large or small, from any one who pities little children suffering for want of care.

Next come a class of orphanages supported by the devotion of single individuals who conduct them and solicit funds. One such institution is the Leonard Street Home, Atlanta, Ga, conducted by one frail 
English woman, and conducted not like a charity but like a loving human home.

The Home was founded in April, 1890, and chartered September, 1890.

Our three buildings were once used as barracks for soldiers, later for dormitories at Spelman Seminary. For the last nineteen years they have served as a home for needy children.

As our work is undenominational and without the help of any organization, we are dependent on donations from Christian people. Last year $\$ 1,596.18$ was received in this way, the rest of the support coming from the relatives of the children who, when it is possible, pay four and a half dollars per month for board, but of our present family of fifty-five (55), ten (10) are paying this full amount. Fifteen are paying half, and twenty-four (24) are entirely dependent on the home, while six (6) large girls are working full time for board and tuition. We are very anxious to increase the spirit of "self-help," and therefore do not wish to relieve any relative of responsibility by having them legally bind their children to the Home, though the Home does have legal claim to deserted children.

Colored workers took up such homes first as agents of philanthropists, as are these two cases:

Laing Orphans' Home for Colored Children is located at Mt. Pleasant, S. C. (a suburban town of Charleston). This institution is under the charge of Miss A. Munes, who also has charge of the public school of the town. This institution is supported largely by a Society of Friends in the North.

In Richmond, Va. :

The Friends' Orphan Asylum was a gift of the Friends to the colored people. Some money was left to it by a white friend and it is in very good condition. It is supported by the colored churches here, aided by the generous gifts of white merchants and friends.

Gradually there has arisen with the Negro race the call and work of this sort. The woman who founded the Tent Sisters' Home in Raleigh, N. C., writes:

A place is needed to protect the children. Oh, that you could see the condition of social affairs here in the State.

I am in close touch with four little girls, ages from ten to thirteen, from homes where the helping hand is necessary. I have them interested in music, so they gladly come within my reach, and I have been repaid for my effort.

Another girl about eighteen is living in our home as one of our family, and her interest is now aroused for an education.

Somebody must do this great work. The respect and confidence of the street urchins and of individuals of the different classes have been gained, but some place to gather them in and with interesting work lead them to be true and honest men and women should be provided.

I have not yet been permitted to personally speak with those who can and will do great things for us financially, "But think on me when it shall be well with thee, and shew kindness, I pray thee, unto me and make mention of me unto Pharaoh [your wealthy and generous friends] and bring me out of this house."

Some of the promoters entering the field to do this work have been doubtful characters. In one IVestern city, for instance, is "another 
small orphans' home, managed by a man named _- It is smallhas about a dozen children-is supported by 'prayers and subscriptions.' Through the efforts of this man (many have no confidence in his honesty) the condition of the little waifs that he finds is improved, even if he does get his own living by the subscriptions."

Other men succeed in getting State aid, and develop great executive ability. For instance, in Charleston:

The Orphan Aid Society was organized by Rev. D. J. Jenkins, December 16,1891 , for the purpose of establishing an orphan house for colored orphan children. However, this was the first step in the great philanthropic work to be organized and operated by individual efforts of the African race. The object is to maintain and educate the orphan and destitute children of the cololed race. This work began with four children. From January 4, 1892, to May 1, 1896, we had on the roll five hundred and thirty-six children, eight teachers and two laborers. A farm of one hundred acres of land was given to the society by Deacon Joseph Wild, of the Greenwood Baptist Church,Brooklyn, N.Y., for the purpose of training the children in the industrial line as well as educational.

The gift brought to the mind of the Orphanage Man the idea of establishing a reformatory for little orphan and destitute boys who are convicted in the Police Court for menial offences. The work has grown rapidly. The Judge of the Recorder's Court has been very favorably impressed with the work and has been a very staunch friend to it from its incipiency. The City Council has been very much impressed with the work of the Jenkins' Orphanage and Industrial School for Colored Children; their interest is manifested by what they appropriate annually. They appropriated $\$ 200$ in $1897 ; \$ 250$ in $1898 ; \$ 300$ in $1899 ; \$ 300$ in $1900 ; \$ 300$ in $1901 ; \$ 500$ in $1902 ; \$ 500$ in $1903 ; \$ 500$ in $1904 ; \$ 1,000$ in $1905 ; \$ 1,000$ in $1906 ; \$ 1,000$ in 1907 .

A similar case is that of Amanda Smith, a notable character.

The Amanda Smith Industrial Orphan Home.

The above named industrial home has been founded by Mrs. Amada Smith for the purpose of caring for colored children who, by death of parents, or otherwise, have been left without homes or natural protectors.

Her plan is to keep the children in this Home only until they can be suitably provided for in permanent homes elsewhere.

There are at the present time thirty-one boys and girls in the Home, and since it was opened in 1899 sixty have been received and cared for. Several of those who have been trained here are now employed in household work.

The Home is located at Harvey, about twenty miles south of Chicago, on the line of the Illinois Central Railroad.

The property consists of eight lots of ground, 25 by 100 feet each, in Harvey, on which the buildings stand, leaving sufficient space for playground, garden, etc.

The founder, Mrs. Amanda Smith, is a widely-known colored evangelist whose history is, in several respects, remarkable.

She was born in slavery but, while she was yet a young girl, her father by hard work and self-denying economy was able to purchase his own freedom and that of his wife and children. Amanda's educational advantages were very meager, consisting of only three months' schooling. She was converted in 1856, and some twelve years later she began work as an evangelist. Her success from the beginning was marvelous. Everywhere crowds attended 
her services, sinners were converted and believers were led into a deeper experience of the things of God.

Her labors were not confined to America, but extended to England, India and Africa. Wherever she went God signally blessed her work, as thousands of witnesses can testify.

She is now sixty-six years of age and can not reasonably expect to continue many years more in active service. This Home is the object to which she is devoting the closing years of her unselfish life. It is her ambition and earnest desire to place it on a permanent basis of support before she dies.

\section{Financial Statement}

ENDOWMENT FUND

Amount recelved to May 1, 1908....\$3,140 77

Lot, gift of McFadden............. 40000

Rent of house on Desplaines street. $\quad 7200$

$\$ 3,61277$

\section{EXPENDITURES}

Cost of lots 17, 18, 19 and $24 \ldots \ldots \ldots \ldots \$ 69963$

Uost of two Homes................ 1,800 00

Assessments, insurance, etc....... 32510

Total expenditures............... $\$ 2,82473$

Balance on hand

$\$ 78804$

\section{Current Expense Account}

\section{RECEIPTS}

Cash donations from July, 1901,

to J une, $1903 \ldots . . \ldots \ldots \ldots \ldots \ldots \ldots$...... $\$ 2,99392$

From the "Helper" to J une, 1903. 1,298 50

" Children's board......... 45175

" Sale of book............ 13239

Total cash receipts...... $\$ \overline{\$ 1,87956}$

Defleit

$\$ 68+12$
Printing to June, $1903 . \ldots \ldots \ldots \ldots \ldots \$ 98868$ Postage (domestic and foreign). 13405 Publishing book ............... 37839 Repairs on property........... 1,60884 Furnace, etc................. 8275 House exp., fuel, laundry, etc... 1,624 95 Shoes and dry goods............ 68 64 Incidentals-express, freight,etc. 65738

Total expenses............. $\$ 5,54368$

Another case is the Louise Juvenile Home of Chicago. Its founder and manager, Elizabeth MrDona!d, writes:

For fifteen years I have been engaged in the rescue work, in this State and in other States. In the North as far as Minnesota, west as far as Omaha, Neb., and east as far as New York, and to the southern extremity of Illinois.

Seeing that in the prisons the larger majority were colored according to population; knowing that we have always had prisons and dungeons, and people have been burned at the stake and hare been hanged by the neck and nothing seemingly to have done any good in regards to reforming one that has fallen, experience in my rescue work has taught me that it would be easier to prevent crime than it is to reform hardened criminals. So after serious and prayerful study to Almighty God I was convinced that a Christian Home for the training, both spiritually and temporally, was needed. So on October 3, 1907, we established the Louise Jurenile Home for dependent and neglected children in my own private home, in which we care for fifty-six children and two mothers, through the assistance of a very grand young woman by the name of Miss Elizabeth Scott, a student of Walden University, giring her entire assistance as matron free. She has really been the 


\section{Orphanages}

only help that we have had. She also taught school in the common schools of Kentucky and is worthy of support, but our institution being a charitable one we are unable to give her any salary.

Our first anniversary was held last October, and then we were able to show to our friends what we had accomplished in one year's time. This is what we had done: purchased an eleven-room house costing $\$ 2,400$, and by renting the upper flat we were able to occupy the lower flat and furnish it up nicely for our work.

Our Home is industrial. The children are taught washing, ironing, cooking, sewing (such as plain sewing), embroidering, hemstitching, etc.

The children attend the public school, which is two blocks from the Home.

We hope to have very soon all the material that it takes to train the children. We have girls ard boys. The boys are not over twelve years of age.

I am a member of the Institutional Church, and have been a probation officer of the Juvenile Court ten years; giving my time and labor free of charge among my people; also Evangelist of the A. M. E. Church and of the Iowa Conference for the past eleven years.

Our work was supposed to be supported by charitable donations, but we have failed absolutely along that line, and the most support we have is my lecturing and evangelistic work, with a few exceptions; the parents pay $\$ 1.00$ to $\$ 1.50$ and $\$ 2.00$ for their children, sometimes.

The North Georgia Industrial Orphanage has this story; the founder says:

I came here from Atlanta as pastor of the B Street Baptist Church June 1, 1907, and being insisted on by some of our members who had tried, we set to work, and on September 19, 1907, effected an organization in an old tworoom house which the city had used for a schoolhouse which we secured free of charge. We soon found a larger house of nine rooms at 303 Blossom Hill. Here we had a fire which did us thirty or forty dollars damage. Finding that we did not have room enough we bought two acres out near the Calhoun road, and are now erecting a cottage where we hope the Lord will help us to finish our work. The best colored people are with us, and our property will aggregate when finished about eight hundred dollars. Our work is strictly industrial.

We moved into the new home on the $22 \mathrm{~d}$ of March, 1909, and although we have had some very rough nights the Lord has helped us. We depend absolutely on charity. We are still in need, but believe and trust help will come to us.

Mrs. - gave us a goat, and we have a pig and some chickens.

We hope to teach cooking, sewing, and other things that will be necessary for life, that they may be the people sought after, and we anticipate a splendid future.

The Weaver Orphan Home for Colored Children, at Hampton, Va.:

Was opened for the reception of children in June, 1904. It is managed and controlled by Mr. W. B. Weaver, his wife and another helper. At present there are thirty-nine children in the home. It costs $\$ 1,500$ a year to support the home, including clothing. The colored people give two-thirds of the money and about nine-tenths of the donated groceries. 


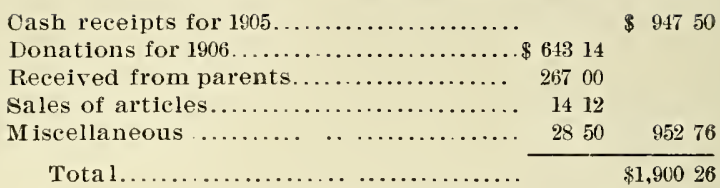

Perhaps the most interesting of all this class of orphanages is the Reed Home and School, Covington, Ga.:

I was among the first pupils at Knox Institute. As soon as I was old enough to know and understand what slavery meant to my people it was a great grievance to me. The non-freedom of speech was one of the first awakenings of my mind to the fetters of bondage. My mother and her sister were owned by different masters, and when they visited each other I noticed they conversed in whispered tones; and even after the war-whoop was hushed, "the river crossed" (meaning freedom in their unwritten language), the sunlight of liberty shone in our home, around our own fireside, the two devoted sisters still whispered; the habit had become so fixed that it was as unbreakable as a cable, and I often wept when I heard them, for I knew that freedom in its true sense could never be realized by them. In 1868 we moved to Atlanta, Ga. I attended Storr's School. From there I went to Atlanta University and graduated from the normal course in 1883. While a student at Atlanta University I taught school during my vacation, in the rural districts, and there got an insight of the general needs of my people. These experiences I received while teaching helped much in fixing un purpose in life. 1 grew more anxious to finish my course in school that I might go out and be of some serrice to my people. The thing that most inclined my heart and made me more determined than ever before was something that I saw while a student at Atlanta University. I could not, if I should try to, explain this scene, for there are no words to express my sad feeling that day.

There is a street cut through the campus of the Atlanta University and a bridge across this street was being dug out by chain-gang hands. One cold, icy morning I was crossing the bridge and heard a pitiful scream below. I looked down and there stood a poor little boy of about nine or ten years old, with the lash being applied to his back. There was no one to say a word of comfort to this dear little fellow. It pressed my heart and caused me to weep bitterly in classroom. When school was dismissed I hastened to my room, for I didn't want to see any one. I at once pleaded with the Lord and asked him for strength to complete iny course, that I might go out to save at least one boy from the chain-gang. I soon felt the comforter and went about my school duties as before.

In July, 1883, I began teaching school in Covington, Ga. The school term at that time was only three months, from July to October. I closed school the last week in September, as most of the children had to help pick cotton. The first of November I opened private school and taught through the winter. In June, 1s\&t, I set up housekeeping for the purpose of caring for one little girl. I made most of my furniture of dry goods boses, and now and then a friend gave me a plate, a cup and saucer or some little piece necessary for housekeeping, and we did our cooking in orens and frying-pans on the fireplace, as we had no stove. I set up housekeeping in one room, and lived in this room until there were five little ones in the family. I then moved where we could have two rooms and lived there until there were eleven in the family. I then bought a place in 185 i on which stood an old $\log$ cabin of 


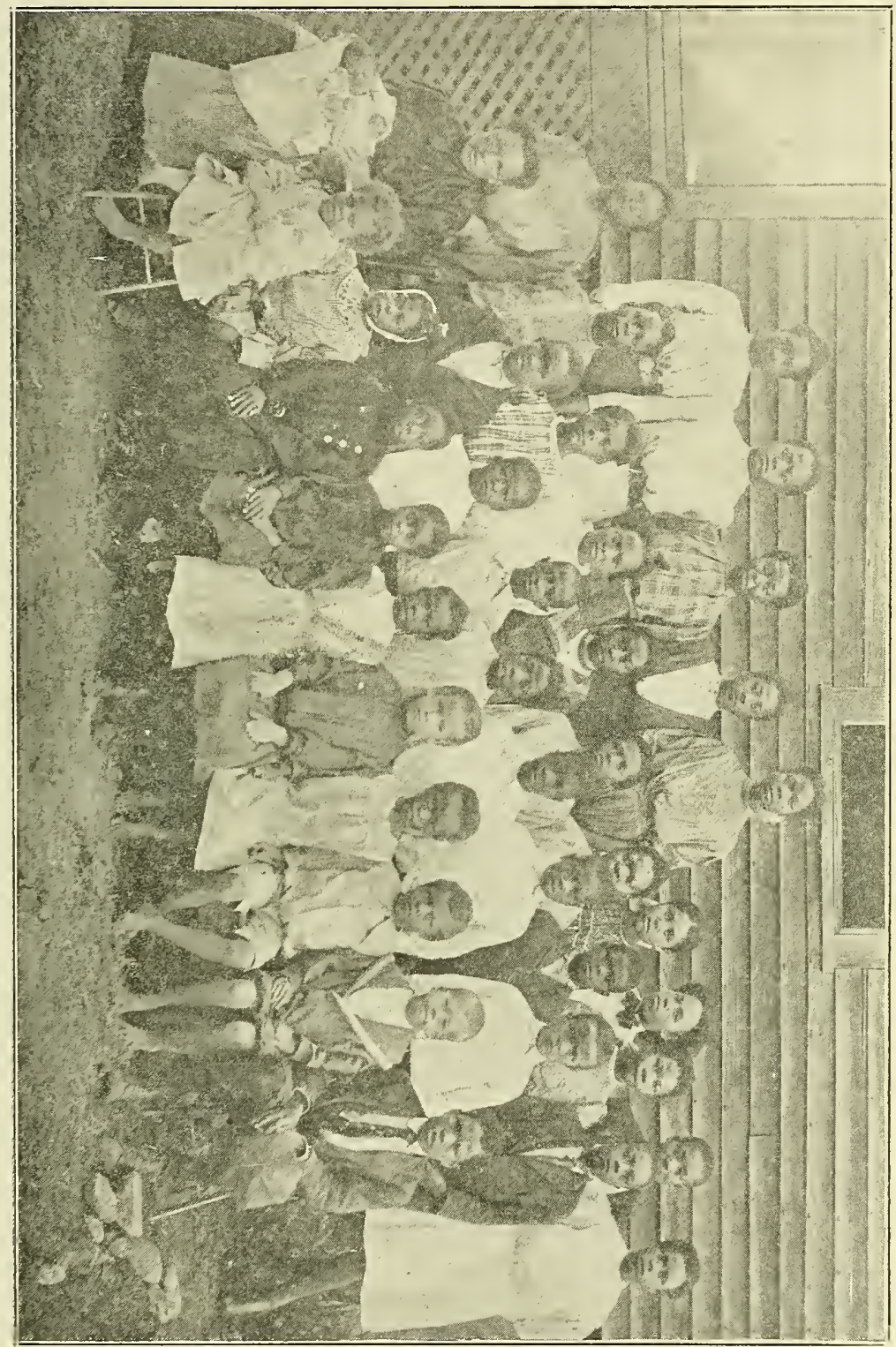


three rooms. In 1891 the family numbered fifteen and a friend, Mrs. H. C. Reed, from whom comes the name of the Home, gave a thousand dollars. This, with the aid of others, enabled us to have a building of ten rooms. This building is now so crowded that we haven't a spare room for the sick when such is our lot. My salary for teaching was not sufficient to support the work, so I had a farmer to teach me how to hoe cotton, so that I could have something for the children to do to help themselves, and at the same time have them do the kind of work so that I could be with them while at work. In the spring we all went out to work in the field and earned all we could toward our own support; in the iall we picked cotton. This, with the aid of friends, helped much. Three years ago we finished paying for a hundred acres of land. On this place we hope to permanently settle the home.

At the beginning I only took girls, but now I have a large number of boys as well as girls. It makes the work doubly hard, but the boys must be cared for. We need men in the race, and it is very necessary that we take greater interest in the boys than we have before, so that there shall be better homes and better citizens. When I took the first boy into the family I felt now I had kept my agreement with the Lord. The boys are a great help, too, for they do all of the farm work.

Our school is not kept up by the county, State, or any educational fund, and we have to depend on our farm for our main support. We also help other planters gather in their crops, and during the months of September and October we are more than buss in this way, picking cotton and doing other things every day except Saturday, when we work for ourselves. The children seem to realize that this ontside work is teaching them how to do for themselves, hence they are rery diligent little workers.

Since 1905, however, we have purchased 75 acres of land, four mules, two oxen, a brick machine, and we are buying a sawmill, paying for it with money we earn by sawing timber. We make brick, saw lumber from our land, and farm.

The Home owns at present:

\begin{tabular}{|c|c|}
\hline 175 reres of land.... & $\$ 6,12500$ \\
\hline Four mules........................... & 47500 \\
\hline 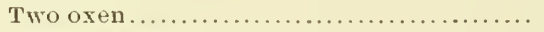 & 8000 \\
\hline 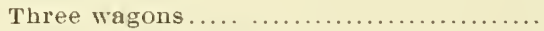 & 11500 \\
\hline Farming implements ..................... & 7500 \\
\hline 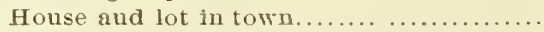 & $z, 00000$ \\
\hline 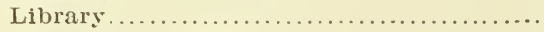 & 50000 \\
\hline Household furuiture.................... & 50000 \\
\hline
\end{tabular}

At present there are forty children in the Home.

In case a strong character like this dies the work is apt to suffer, as in the case of the Garred Orphanage, Columbia, S. C.

The Orphanage is a poor, struggling institution. During the life of its founder it did very well; but since her death it has been in very bad shape.

Out of these which we might call personal homes have grown the institutional orphanages conducted by boards, trustees, ete. One of the best is in Lexington, $K y$. This institution is sixteen years old and shelters thirty to forty inmates. The children attend school and are taught sewing, cooking, blacksmithing, shoemaking, la undering, chairbottoming, etc. Their income in 1908 was $\$ 7,826$. 
In New Castle, Pa., is a Home for Destitute Negro Children supported by the State Federation of Colored Women's Clubs.

The Colored Orphan Home of Western North Carolina has thirty-five children, and is controlled by eight colored directors.

The Dickson Colored Orphanage of Gilmer, Texas, is partly a State institution and partly supported by colored people. It is said to be doing an "admirable work."

In New Orleans are several Shelters, mostly due to the munificence of the Negro philanthropist, Lafon.

The Waifs' Home.-The Waifs' Home is located on City Park avenue and Conti street. It has been in operation for about seven years. It is under the general supervision of the Louisiana Society of Prevention of Cruelty to Children; and the City of New Orleans, through the above-named organization, maintains it. This Home is for boys only, who are sent here by the Juvenile Court for petty offenses. The institution is in charge of Mr. and Mrs. J.G. Jones, two very estimable Christian persons, who are doing their best to reform the boys in their charge. The City of New Orleans also provides the Home with a competent teacher, and Sunday-school instruction is given by the Catholics as well as the Protestants. At the time I visited the Home there were 63 boys who were committed therein.

House of Good Shepherd.-The House of Good Shepherd Convent, located at corner of Bienville and Broad, has 78 girls, nearly two-thirds of whom are colored. This is a Catholic institution and is in charge of Catholic sisters. The main buildings were provided for by the Catholic chureh of this city. However, the late Thomy Lafon in his will left $\$ 20,000$ which was used for the erection of the Lafon Memorial Building, at a cost of $\$ 37,000$. The City of New Orleans contributes $\$ 400$ a month towards the current expenses. Two hours are devoted each day to class instruction, and quite a good deal of industrial work is given. The convent gets its inmates from the Juvenile Court, which sends the girls here for reformation.

The Frances Joseph Gaudet Home.-The Frances Joseph Gaudet Home is located out on Gentilly Road, a few miles out in the suburbs of the eity. This reformatory is the result of the self-sacrifieing efforts of Mrs. Frances Joseph Gaudet, our most notable social worker. The property and buildings are the gifts of philanthropic white eitizens of this eity. It has a farm and derives quite a good deal of support in this way. The inmates are both boys and girls, quite a number of whom are sent here by the Juvenile Court of this city.

The Lafon's Boys' Asylum.-The Lafon's Boys' Asylum was founded by the late Thomy Lafon, who made several gifts to it during his life. In his will he left $\$ 10,000$, which later was increased approximately to $\$ 20,000$ by Mr. Lafon's executor. It is located on Gentilly Road on the outskirts of the city, and has quite a number of inmates, both boys and girls, a large number of whom are mere babies. It, too, is aided by the city, to a small amount.

St. John Berchmann Asylum for Girls.-The St. John Berchmann Asylum for Girls is under the care of the Holy Family. It is maintained and operated by the Catholic Church. The late Thomy Lafon gave over $\$ 25,000$ to this asylum. It is located at 717 Orleans street.

Other Negro Oiphanages are:

Colored Orphan Asylum, Oxford, N. C.

Masonic Orphans' Home, Bennettsville, N. C. 
St. Francis Orphan Asylum, Baltimore, $\mathrm{Md}$. Property, $\$ 60,000$; inmates, 94 .

Friends' Orphan Asylum, Richmond, Va.

Georgia Colored Industrial and Orphans' Home, Macon, Ga. Inmates, 35; income, $\$ 4,350$; property, $\$ 10,000$. New building nearly ready.

General State Reformatory, Macon, Ga.:

RECEIPTS, 1906

Balance ........................... \& 29160

Cash donations from the public........... 3,42570

Other donations, value................ 39930

Amount of produce raised on farm by in-

mates........................ 41500

Total....................

Masonic Home, Rock Island, Ill. Income, $\$ 960$.

Orphans' Home, Huntington, WV. Va. Inmates, 65. The State has been paying two teachers. Ten years.

Jenkins Orphanage, Courtland, Va. Seven years.

Shiloh Orphanage, Angusta, Ga.

Orphanage, Austin, Tex.

Colored Orphans' Asylum, Cincinnati, Ohio. Property, $\$ 100,000$; endowment fund, $\$ 25,000$; income, $\$ 2,010$; inmates, 72 ; receipts, $\$ 3,123.45$.

INMATES

\begin{tabular}{|c|c|c|c|}
\hline & & & \\
\hline & Males & Females & Total \\
\hline Number remaining May $1,1906 \ldots \ldots$ & 19 & I6 & 35 \\
\hline 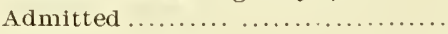 & 19 & 18 & 37 \\
\hline Placed in homes.................... & 5 & 13 & 18 \\
\hline Died $\ldots \ldots \ldots \ldots \ldots \ldots \ldots \ldots \ldots \ldots$ & - & 2 & 2 \\
\hline Cared for during year............... & 38 & 34 & 72 \\
\hline Remaining $\ldots \ldots \ldots \ldots \ldots \ldots \ldots \ldots \ldots$ & 33 & 19 & 52 \\
\hline
\end{tabular}

Total income from Negroes about $\$ 300$.

Universal Progressive School for Orphans, Baltimore, Md. Property, $\$ 1,950$; inmates, 35 .

Children's Orphans' Home, Kansas City, No. Inmates, 100; expenditures, $\$ 65$ per month.

Rescue Home, Kansas City, Mo.

Baptist Orphanage, Baltimore, Md. Inmates, 25.

Orphanage, Richmond, Va.

Gad. S. Johnson's Orphanage, Macon, Ga. Inmates, 25; income, $\$ 1,500$.

Home for Parentless Children, Petersburg, Va.

Maryland Home for Friendless Children, Baltimore, Md. Property, $\$ 2,1000$; inmates, 52; State aid, $\$ 250$.

RECEIPTS

\begin{tabular}{|c|c|}
\hline Brought forward from the year 1905. & $\$ 26947$ \\
\hline 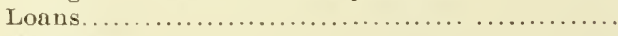 & 85000 \\
\hline 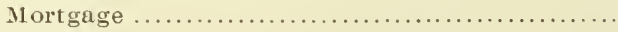 & 1,95000 \\
\hline City aid.. & 82620 \\
\hline tate aid $\ldots \ldots \ldots \ldots \ldots \ldots \ldots \ldots \ldots \ldots \ldots \ldots \ldots \ldots \ldots \ldots \ldots \ldots \ldots \ldots$ & 50000 \\
\hline 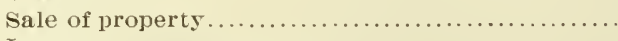 & 1,00000 \\
\hline 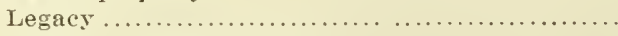 & 9750 \\
\hline 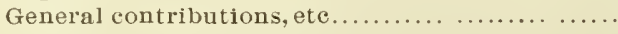 & 64871 \\
\hline
\end{tabular}

St. Louis Colored Orphans' Home, St. Louis, Mo.

Carrie Steele Orphanage, A tlanta, Ga. Inmates, 97 ; income, $\$ 2,200$ ( $\$ 100$ from Negroes directly; the balance from taxes on both races). 
Bridges Orphanage, Macon, Ga.

State Protective Home and Mitchell Hospital, Leavenworth, Kansas. Income, $\$ 2,320.60$ during 1883 .

Home for Destitute Children and Aged Persons, San Antonio, Texas. Inmates, 18.

TWO YEARS' INCOME

Total amount collected by subscription..............\$ 11445

Total amount of special donations ................. 12082

Total amount collected for building purposes......... . 6855

Total amount from Bexar county and Board of Ohildren. 79420

Total amount from tables and entertainments........ $173 \quad 16$

Total amount collected from railway employees........ 8565

Total amount collected from ehurches ............... 119

Total collected for two years..................... $\overline{\$ 1,56+22}$

There are other orphanages in Pensacola, Fla., Jacksonville, Fla., Bellevue, Fla., Topeka, Kan., St. Louis, Mo. (two), Baltimore, Md. (three), Louisville, $\mathrm{Ky}$., beside other places.

Section 13. Hospitals. The old folk's homes are mainly and the. orphanages are largely supported by Negroes themselves. The hospitals, on the other hand, being newer enterprises and appealing to the educated few, are usually promoted and conducted by Negroes, but get their main support from the State or from whites.

The hospitals are the result of two impulses: the philanthropic desire to help the sick, which arose especially after the Civil War, and the scientific efforts of the new Negro physicians, who found themselves cut off from all clinical advantages.

The older type of hospital is represented by the Freedmen's Hospital of Washington, D. C. This is supported by the United States Government, but is otherwise a Negro institution. The Lincoln Hospital and Home, of New York, an old and well-endowed institution, takes Negro patients and trains Negro nurses, but admits no Negro physicians. Another type of hospital has arisen out of the colored wards of Southern city institutions. Colored associations are often formed to help these wards:

The Charity Organization is engaged in helping the colored department of the hospitals.-Frankfort, $\mathrm{Ky}$.

The Colored Women's Hospital Aid Society was organized in last January. We have thirty active members. The object of the society is to assist in the maintenance of the colored ward of the John Sealy Hospital. A t each monthly meeting of the society the small sum of ten cents is collected from each member. It is the custom to disband in June for the summer, beginning work again in October. During this interval dues are paid as if in session. Since our organization we have supplied the hospital with six sanitary beds at twelve dollars apiece; and the women with nineteen garments. The interest has never lagged, and as the society grows older we hope to accomplish much more.-Galveston, Tex. 
In Jersey City, N. J.:

The Charity Club is composed of fifty ladies. The club was organized three years ago for the purpose of assisting Christ Hospital, a charitable institution which admits colored patients without any discrimination. Since our organization three years ago we have given the hospital $\$ 850$. This money is raised by an annual charity entertainment which is heartily supported by all our people.

In the Galveston Colored High School are two hospital clubs.

Often such wards are erected into separate hospitals and given city aid or subscriptions. In some cases such hospitals have been endowed. Specimens of such hospitals are:

Good Samaritan Hospital, Charlotte, N. C.

The Roper Hospital, supported partly by the Roper Fund and an annual appropriation from the city government, has ample accommodations for the colored pauper patients but has no accommodations for colored people who wish a private room.-Charleston, S. C.

Lincoln Hospital, Durham, N. C.

Lamar Hospital, Augusta, Ga.

The most interesting hospitals have come from the efforts of physicians and nurses:

Dr. Matilda A. Evans, of Columbia, S. C., has the distinction of being the first licensed woman physician in that State. She is a Negro and the founder of a hospital and nurses' training school for colored people in Columbia. She was graduated from the Woman's medical college in Philadelphia.

The undersigned physicians respectfully announce that on and after September 20, 1909, Fair Haven Infirmar5, 197 West Mitchell street, Atlanta, Ga., will be open for the reception of medical and surgical patients. We sincerely solicit your patronage.
Drs. A. D. Jones,
TV. F. Penn,
H. R. Butler,
L. P. Walton,
T. H. Slater,
L. B. Palmer.

McKane's Hospital, Sarannah, Ga., is supported by Negro physicians.

The Richmond Hospital is a child of a number of the colored physicians. It is located at $409 \mathrm{E}$. Baker street. It gets some help (\$150 a year) from the city. The other support comes from charity. Dr. M. B. Jones is chlef surgeon and Dr. D. A. Ferguson is secretary of the Board.-Richmond, Ta.

The Woman's Central League Hospital is run at $4 \mathbf{1 4} \mathrm{N}$. Third street by Dr. R. E. Jones. For its support it depends largely upon the colored churches and societies.-Richmond, Ya.

Such hospitals hare a hard struggle to live, but on the whole are succeeding and multiplying.

The Red Cross Sanatarium operates a nurse training department which might be called strictly charitable, as it is not operated for private gain. The Red Cross Sanitarium owed one thousand dollars sereral months ago on the purchase debt, but the leading white women of the eity (representing its culture and aristocracy) came together, and a public appeal to the citizens with their signatures attached quickly raised the amount and settled the incumbrance.-Louisville, Ky. 


\section{Hospitals}

Charity Hospital of Savannah, Ga., was organized by several practicing physicians, and chartered June 1, 1896, by a few hard-working, energetic women anxious to take up and learn nurse training, that they might assist others of the less fortunate with whom they come in contact to better living and conditions of health.

Assisted by their friends in soliciting donations by personal appeal to the public, and through entertainments, sufficient funds were raised by December, 1896, to make the first payment on the purchase price of a two-story dwelling of five rooms in the southwest portion of the city. About five years later, through means from the same sources and the free services of Negro mechanics, an annex was made to the building, giving two large wards accommodating about twelve patients each. A year later we sought and were successful in getting a monthly appropriation from the city of $\$ 25$ per month for taking care of their pauper patients, which amount was increased some years later to $\$ 75$, but not before a thorough inspection and investigation of our work.

The county a year later, after an investigation, made an appropriation of $\$ 25$ per month by our taking eare of their pauper patients.

In 1906 one of our founders and charter members donated a two-story building, which we rolled up to and joined to our building, forming an "L." This we repaired, and fitted up for five private rooms and four nurses' rooms. We have accommodations for eight nurses for the training school, governed and controlled by a head nurse who is also matron.

We have graduated through a two years' course some twenty-five welltrained nurses, who are sought by white families and physicians as well as by those of their own color.

A regular course of lectures is given by our physicians, who compose the medical staff.

For the past two or three years our people, who have always had a horror for hospitals, are waking up to the fact that it is the best place for them when sick, and the demand for applications for admittance to private as well as ward room is more than we have accommodation for.

It has also come directly under our notice that the time spent in the hospital has taught them that fresh air and sunshine instead of keeping them sick with colds, etc., helps and benefits them in every way, and they return home with some ideas of simple sanitary measures which should be in all homes.

While soliciting donations for this work from our own people is in itself uphill work, we have found it much harder to get them to give any amount promised with any degree of system and regularity.

As our building is not so well constructed, a certain temperature can be maintained in the wards only at a very large cost for fuel, and we need more room for private as well as pauper patients. Several lots adjoining us have been secured at the cost of $\$ 2,000$, and we are now planning a campaign for soliciting this from our churehes and organizations, as we wish to get the ground paid for, at least, before starting the building.

Our own people, generally very superstitious and especially so of hospitals and what they call the "Black Bottle" used there, are becoming more and more enthused over their hospital and the work it is doing, and have no hesitancy as heretofore in eoming, and in fact request it of their attending physician.

Below is our report to the city for the year 1908. 
Efforts for Social Betterment

\begin{tabular}{|c|c|c|c|c|c|c|}
\hline & \multicolumn{2}{|c|}{ OHARITy Patients } & \multicolumn{2}{|c|}{ Pay Patients } & \multirow{2}{*}{ 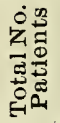 } & \multirow{2}{*}{ 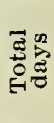 } \\
\hline & Number & Hospital days & Number & Hospital days & & \\
\hline 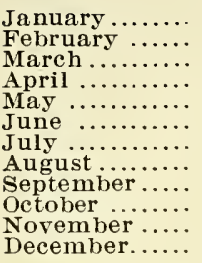 & $\begin{array}{l}12 \\
16 \\
22 \\
22 \\
32 \\
19 \\
17 \\
17 \\
22 \\
24 \\
18 \\
22\end{array}$ & $\begin{array}{l}208 \\
284 \\
288 \\
269 \\
336 \\
308 \\
192 \\
215 \\
333 \\
262 \\
199 \\
303\end{array}$ & $\begin{array}{r}7 \\
10 \\
25 \\
20 \\
15 \\
19 \\
13 \\
8 \\
21 \\
20 \\
18 \\
28\end{array}$ & $\begin{array}{r}73 \\
120 \\
175 \\
169 \\
153 \\
149 \\
151 \\
52 \\
157 \\
163 \\
239 \\
234\end{array}$ & $\begin{array}{l}19 \\
26 \\
47 \\
42 \\
47 \\
38 \\
30 \\
25 \\
43 \\
44 \\
36 \\
50\end{array}$ & $\begin{array}{l}281 \\
404 \\
463 \\
438 \\
489 \\
457 \\
343 \\
267 \\
490 \\
425 \\
428 \\
637\end{array}$ \\
\hline Total........ & 243 & 3197 & 204 & 1825 & 447 & 5022 \\
\hline
\end{tabular}

Patients in hospital January $1,1908 \ldots \ldots \ldots \ldots \ldots \ldots \ldots . .6$

Number of patients admitted during year $1908 \ldots \ldots \ldots \ldots .447$

Number of patients discharged during year $1908 \ldots \ldots \ldots .402$

Number of patients died during year $1908 \ldots \ldots \ldots \ldots \ldots \ldots .54$

Number of patients remaining January $1,1909 \ldots \ldots \ldots \ldots, 17$

Number of births............................... 5

Total number of days, charity patients............ 3197

Total number of days, pay patients ................ 1825

Total number of days, all patients................. 5022

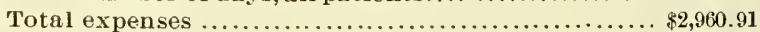

\section{RECEIPTS}

Appropriation from the eity ...........\$900 $\$ 00$ Appropriation from the county ............ 30000

From pay patients .................... 1,563 96 Donations-Ohurches, societies, indiriduals 47209

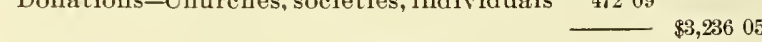

EXPENSES

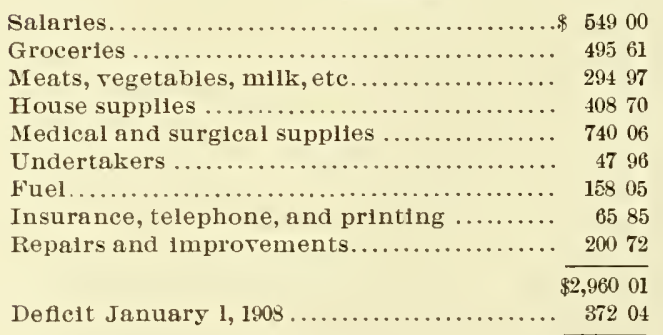

Defleit January 1, 1909

One of the most interesting buildings in Charleston, S. C., is:

The Hospital and Training School for Nurses, an institution devoted to the preparation of colored women for the profession of trained nurses.

The building itself is an old residence erected in the year 1800. Its solid walls, despite wars, storms and earthquakes, are as firm to-day as when first erected more than a century ago. In the year 1897, Dr. A. C. McClennan saw that trained nurses were needed in Charleston and that it would be well to establish a training school. After consultation with some of the other col- 
ored practitioners a course of lectures was arranged and, a room having been secured, the school was opened.

The large attendance showed that the school was destined to fill a long-felt want, but it soon became apparent that didactic instruction alone could not accomplish the desired end. The nurses needed practical instruction in a hospital ward. An attempt was made to arrange for such instruction in one of the public charitable institutions of the city; but after conferense with the various boards having these institutions in charge, it became clear that nothing could be accomplished along that line, and that the school must have a hospital of its own. A meeting of eitizens was called and an association was formed and incorporated.

The building which the school now occupies was for sale, the price being $\$ 4,500$. By means of entertainments and subscriptions $\$ 500$ was raised, and npon this small margin the building was purchased. Ten years have worked a wonderful change. The building, old and dilapidated, has been repaired and remodeled, and equipped to meet the needs of the work; the grounds have been leveled and drained, and outside and inside both buildings and grounds are in keeping with the character of the work. Meanwhile the debt upon the property has been reduced from $\$ 4,000$ to $\$ 500$.

Forty-five trained nurses, representing ten graduating classes, have been sent out and all of them have found employment and have given satisfactory service. Thirteen are residing and working in Charleston; the others are widely scattered, one of them being in northern New York, one in Florida, one in Ohio and one in California.

One of the most noteworthy cases treated at this institution was that of the family of Fraser Baker, postmaster at Lake City, S. C. Baker was killed and the members of his family seriously wounded by a mob, who set fire to their home and fired on them as they were making their escape from the burning building. These people were brought to Charleston and treated at the hospital free of charge. The expense of caring for them was considerable, and the institution could ill afford such a drain upon its resources, but it was done nevertheless. They were all discharged cured, and afterwards removed to Boston, Mass.

The hospital has been of great benefit to the people living in the country districts near Charleston, where it is difficult and at times impossible to obtain medical treatment. The charge made for patients in the hospital is very small,barely enough to cover the cost of food and medicines. There is a constant demand for the services of the nurses connected with the training school, and the fees paid for their services constitute the principal source of income for the institution. The great need of the work is money to erect additional buildings. A nurse dormitory is especially needed. There are always a large number of applicants for admission for nurse-training, but owing to the limited space only a small number can be accommodated. Yet with all the disadvantages the work still grows; those in charge of it are doing the best they ean with the limited means at their command, and hoping that the time may come when some wealthy philanthropist may become interested in the work and supply the funds needed to enlarge the building.

In Pittsburgh :

The B. T. Washington Hospital and Nurse-Training School was organized October 30, 1907, by a few women.

In July, 1908, we purchased a twelve-room building located on La Place 
street at the cost of $\$ 7,000$. We have two wards fitted up for male and female ready for operation. We have a head chief nurse, the staff and resident physician.

In Dallas, Tex. :

The Wright Cuney Memorial Nurse-Training School is an association of the best element among the Negroes of this city for the purpose of conducting a school for the training of sick nurses.

In Kansas City, Kan. :

The Douglass Hospital is kept up largely by the citizens and church of this city and Kansas City, Mo. The organization has been taken in charge by the A. M. E. Church.

In Houston, Tex. :

The Feagan Hospital is a new enterprise, but within the past year it has done a vast amount of good for our people. Patients are received at a very small cost, by week or month. Medical services are given free and Mrs. Feagan, a trained nurse, is in constant attendance.

Frierson \& Co.'s ambulance conveys patients to and from the hospital, free of cost.

In Greenville, Miss. :

There is one Circle of the King's Daughters in Greenville, Miss., and they together with the white Circles of that city have built and operate a hospital.

Out of such beginnings have grown several large well-equipped hospitals; perhaps the best in the country is the Provident Hospital and Training School of Chicago:

Provident Hospital and Training School for Nurses has been in successful operation more than ten years. It was founded through the united efforts of a few earnest colored men. A building at the corner of Dearborn and 29th streets was rented, 14 beds were installed and its mission of earing for the sick poor regardless of race or creed was inaugurated.

In its early days it passed through gloomy and anxious periods. Several times it looked as though the doors would have to be closed, but renewed and sustained efforts on the part of the trustees arerted the calamity.

The men who founded the institution were poor. The race it most sought to benefit is the humblest and most ostracized of races, yet the earnest and heroic struggles to maintain the institution won the confidence of many of Chicago's foremost men. The splendid generosity of Philip D. Armour, Nathan M. Freer, Herman H. Kohlsaat, George M. Pullman, George H. Webster and others made it possible to build and maintain a hospital which in administration, method, equipment, appointments and convenience is equal to the best in Chicago. Here orer 3,000 sick persons mostly among the poor have already been scientifically cared for.

Five of the hospital staff of physícians and surgeons are colored men of education and attainments. To the hospital every year or two is admitted as an interne a bright colored doctor just graduated from one of the medical schools. These men otherwise could not secure the benefit of a hospital connection or experience. And in this hospital, although 65 per cent of the patients ar'e white, a colored man can at all times be sure of advanced medical skill and sympathetic trained nursing.

The hospital and its allied charities is incorporated and is managed by a board of eighteen trustees of different creeds. Six only of the trustees are 
white. As the result of ten years of effort the association has accumulated property worth $\$ 100,000$ upon which there is no encumbrance whatever. Notwithstanding the most rigid economy, there is, however, an annual deficit of about $\$ 3,500$ which is made up by voluntary contributions and the revenues from associate memberships which call for the payment of ten dollars on the first of May in each year. These memberships are open to all and the aim is by this means to secure the interest of a great number of men and women who feel that they should be doing something for a people who are as yet financially unable to extricate themselves from conditions which have been imposed upon them by others.

When Provident Hospital was opened but one training school in America would receive colored women as students. With this exception it was then impossible for these women to be trained in the art of scientific nursing. This condition produced the training school, the hospital being in fact a means to this end. Colored nurses only are admitted. It has been in successful operation since the founding of the hospital. For the first five years the school suffered for lack of proper accommodations and equipment, but the few nurses the institution was able to accommodate, by their great patience, self-denying interest and earnest work, fixed the future not only of the training school but of the hospital. Now the early prejudice against the colored nurse has almost entirely disappeared. Patients are sent to the hospital by eighty physicians in addition to those of the staff, many of them believing that here more uniform and intelligent attention is given than can be secured elsewhere. The term is two years of actual service; the requirements for admission, good health, good moral character, and a high-school education or its equivalent. The selection of nurses is made after careful investigation, only one out of twenty applicants on the average being received and then upon three months probation.

Forty-one nurses have graduated. They have come from all parts of the United States, thus making the training school national in character. However, a majority of them have been from the South where their advancement wonld be especially difficult, and, in accordance with the wish of the trustees, they have returned to that part of the country as helpers and workers in the perplexing problem of uplifting the downtrodden of their people. Earnestness, intelligence, patience and sympathy must be combined in the nurse who would graduate from this school.

"Esther Freer Home," the dormitory for the nurses, is probably the most complete and artistic of its kind to be found anywhere and the young colored women, always poor, who are admitted feel during life the refining influence of this comfortable home with its atmosphere of benevolence.

When Armour Mission was founded, among its other activities was a free dispensary. This was transferred to Provident Hospital and became one of its departments. The aim has been to charge each patient ten cents for a preseription, a nominal payment being thought consistent with the wisest charity. None, however, who cannot pay is refused attention or medicine. More than 25,000 persons have been treated.

District visiting is an interesting feature of the training-school work. Into the more negleeted sections of the eity Provident nurses go daily, ministering to the poor and sick of both races. This service is attended with most gratifying results. The influence for good which these young women carry into many homes cannot be calculated. Practical instruction is given in the care of the sick, in house ventilation, in the preparation of food, in cleanliness of home and body, all in a gentle and effective manner. The work is of the 
utmost importance and when sufficient funds are available will be widely extended.

Provident Hospital was founded with a subscription of $\$ 350$.

We may judge the results from the following figures :

Number of patients in the wards and private rooms in 10 years. 3,000

Number of homes visited by the nurses in 5 years............ 679

Number of visits made in 5 years...................... 2,927

Amount of property accumulated................ $\$ 100,000$

Donations received for operating expenses........ 33,147

Amount collected from patients for hospital service $\mathbf{5 2 , 5 2 4}$

Total revenue for operating expenses............ 85,672

These figures are gratifying. They show the peculiar merit of the institution in accomplishing so much with comparatively small means. They indicate how much more might be accomplished with ample means. They mean that there is maintained among the 35,000 colored people of Chicago a permanent object lesson to all who are struggling upward, teaching that the best hope of rising lies in doing a thing well.

The Frederick Douglass Hospital of Philadelphia:

Was founded in 1895 and incorporated the following year under a charter by the legislature of Pennsylrania. It has done and is still doing a much-needed work in the care and treatment of the humble and indigent sick, especially of the colored race, and also in the training and equipment of colored young women for the important functions of the professional nurse, and also giving a large field of practical service and usefulness especially to the thirty-five colored physicians of Philadelphia.

A post-graduate course is planned for doctors of medicine.

The hospital, while largely under colored control, has leading white and colored physicians on its staff, and its doors are open to all, without discrimination either of race or religion. The young women in its training school for nurses have been drawn from States North and South, and they are proving themselves erangels of mercy and helpfulness in the homes of the afflicted in various parts of the country.

Since its founation the hospital has treated nearly 2400 in-patients and upwards of 30,000 out-patients. Such work as this must command the confidence of any community.

Some hospitals are connected with schools, as those at Hampton, Spelman Seminars, and especially the one at Louisville connected with the Colored Medical School:

The Citizens' National Hospital is a part of the Louisville National Medical College. It was first organized in conformity to the laws governing medical schools. In 1904 we mored into our present quarters. The new home was given the present name.

The hospital is supported by board money from patients and tuition from medical students.

We have a training class for nurses (girls only), seren in class.

We do all the charity work our friends will permit. This is not much.

Hospital on grounds with College, combined value about $\$ 8,000$.

We receive no help from the city and a rery little from the public, perhaps about three hundred dollars from all sources in the last five years.

Capacity, twelre beds.

Other Negro hospitals are said to exist as follows: 
Mercy Hospital and Nurse Training School, Ocala, Fla.

Mercy Hospital and School for Nurses, Philadelphia, Pa. Total income to November, $1907, \$ 6,474.02$; patients, $\$ 4,232.00$; received from Negroes, $\$ 4,390.69$, and from the State $\$ 5,000$ every two years.

Mitchell Hospital, Leavenworth, Kansas. Income, $\$ 2,320.60$.

Taylor Lane Hospital, Columbia, S. C.

Mercy Hospital, Nashville, Tenn. Patients, 394 ; total income, $\$ 1,873$, all from Negroes.

Harris Sanitorium, Mobile, Ala. Patients, 25.

Colored Hospital, Petersburg, Va.

Provident Hospital, Baltimore, Md. Property, $\$ 15,000$.

Burrus Sanitorium, Augusta, Ga.

Colored Hospital, Evansville, Ind.

Provident Hospital, St. Louis, Mo.

State's Hospital, Winston, N. C.

Colley's Hospital, Cincinnati, O.

Hairston Infirmary, Memphis, Tenn.

Dr. J. T. Wilson's Iufirmary, Nashville, Tenn.

Colored Hospital, Dallas, Tex.

Woman's Central League Hospital, Richmond, Va.

Slater Hospital, Winston-Salem, N. C.

Hale Infirmary, Montgomery, Ala.

One interesting work is the Dispensary conneeted with the First Baptist Church of West Washington, D. C.

We have treated about one hundred and fifty persons at theDispensary. We have not been open for business quite three months, yet the work is growing, however, and we feel that much more will be accomplished as the community becomes acquainted with the work.

Section 14. Young Men's Christian Association and Young Women's Christian Association.-These Christian Associations reveal in their history the curious complications of the Negro problem in America. In the South there is, in the recent abolition of slavery, an historical if not a logical excuse which lets the color separate Christians.

In the North there is no such excuse, and yet Negroes have been gradually excluded from Young Men's Christian Association buildings in New York, New Haven, Philadelphia, Chicago, and other large cities and segregated in separate bodies, while from the first they were in nearly all cases refused admittance to Young Women's Christian Associations. These separate Negro bodies are now growing and flourishing, but they are and are felt to be monuments to a miserable unchristian and unmanly prejudice. Of course if they represented voluntary segregation like the German associations or the Railroad men the case would be different; but this separation is compulsory and humiliating. The colored bodies have flourished because earnest and self-sacrificing secretaries have urged them on and counseled them to 
ignore the stigma. In this way they have done great good. But the good accomplished is no excuse for the insult offered.

Figures for the Colored Young Men's Christian Associations follow:

The Colored Men's Department now has 136 associations-96 in educational institutions and 40 in cities-with an aggregate membership exceeding 11,000 young men. Notwithstanding the financial stringency of the past year, two new city associations and six new student associations were added to the list, a new building was dedicated at New Orleans, and the corner-stone of the $\$ 100,000$ building for Washington, D. C., was laid by President Roosevelt. The year was specially characterized by the splendid advances made in nightschool work and by the increased attendance upon religious meetings. Ten colored student associations sent delegates to the first International Student Bible Conference at Columbus, Ohio.

\section{Colored Young Men's Christian Associations}

Alabama.-Nobile.

California.-Los Angeles.

Connecticut.-New Haven.

District of Columbia.-Washington : real estate, $\$ 52,000$; debt on same, $\$ 2,000$.

Georgia.-Americus. Atlanta: real estate, $\$ 4,500$. Angusta. Columbus:

value of real estate, $\$ 26,600$.

Illinois.-Normal.

Indiana.-Indianapolis.

Iova.-Buxton: Colored popnlation, 5500 ; value of building and lot, $\$ 23,500$; other real estate, $\$ 500$; valne of boys' building and lot, $\$ 10,000$.

Kansas.-Topeka.

Fentucky.-Louisville : value of buildiug and lot, $\$ 10,000$; debt on same, $\$ 2,750$.

Louisiuna.-New Orleans: value of building and lot, $\$ 6,400$; debt on same, $\$ 1,200$.

Marylund.-Baltimore: valne of bnilding and lot, $\$ 3,000$.

Missouri-Kansas City: value of real estate, $\$ 7,200$; debt on same, $\$ 6,000$. St. Lonis: value of building aud lot, $\$ 5,500$; debt on same, $\$ 2,000$.

New Jersey.-Atlantic City. Montclair. Orange.

New York.-Brooklyn : value of building and lot, $\$ 6,400$. Elmira. New York city : value of building and lot, $\$ 32,060$.

North Carolina.-Asheville: value of building and lot, $\$ 35,000$; debt on same. $\$ 1,580$. Charlotte. Winston-Salem.

Ohio.-Springfield: building, $\$ 5,000$; debt on same, $\$ 1,200$.

South Carolina.-Charleston. Columbia.

Tennessee.-('hattanooga: building and lot, $\$ 8,800$; debt on same, $\$ 4,175$.

Kuoxville: building aud lot, $\$ 2,000$. Nashville.

Texas.-Dallas. Fort Worth.

Tirginia.-Charlottesville. Norfolk : value of building and lot, $\$ 16,000$, debt on same, $\$ 1,600$. Portsmouth : funds paid in, $\$ 1,070$; pledged in addition, $\$ 10,930$. Richmond: value of brilding and lot, $\$ 7,000$; funds paid in, $\$ 175$; pledged, $\$ 730$. West J'irginia.-Bluefield. Wheeling.

\section{Colored City Associations}

39 colored city associations exist.

28 of these report officers or statistics.

28 report 5,379 members.

26 report 2,\$36 active members.

24 report 1,300 serving on committees. 
24 report a total amount paid out for current expenses, $\$ 41,947$.

22 report a total average daily attendance at rooms of 1,070 .

22 report 211 socials and receptions.

20 report 103 paid lectures and entertainments.

16 report 373 situations secured.

13 report gymnasiums, with 512 using same.

15 report 68 athletic teams or clubs, with 589 members.

7 report 289 enrolled in gymnasium classes, and 47 in leaders' corps.

7 report 56 matched games with outside teams.

\section{EDUCATIONAL}

22 associations report some educational information.

20 report reading-rooms with 499 periodicals on file.

16 report 188 educational lectures and practical talks (not including popular courses).

9 report 22 educational clubs, with 489 members.

16 report 49 educational classes, attended by 391 different students.

12 report 22 paid teachers.

19 report $\$ 1,322$ total expenses of all educational work.

10 report $\$ 597$ total receipts from class tuition fees.

BIBLE STUDY

18 associations report Bible study statistics.

18 report 708 different students in Bible classes: men, 523 ; boys, 185

16 report 22 miscellaneous Bible classes of men, with 394 students.

1 reports 1 evangelistic Bible class, with 8 students.

6 report 8 Bible training classes, with 113 students.

7 report 11 boys' Bible classes, with 220 students.

14 report a total Bible-class attendance for the year of 13,922 .

\section{RELIGIOUS MEETINGS}

24 associations report statistics of religious meetings, etc.

20 report 355 men serving on religious-work committees or doing personal religious work.

16 report $\$ 963$ paid out for religious work.

3 report 192 shop meetings with a total attendanceof 4,452 .

22 report 808 evangelistic meetings for men, with a total attendance of $68,111$.

22 report 1,121 all meetings for men, with a total attendance of 84,292 .

4 report 148 meetings for boys, with a total attendance of 3,425 .

22 report 1,620 average per week at all-men's meetings.

4 report 67 average per week at all-boys' meetings.

17 report 283 total professed conversions: men, 245 ; boys, 38 .

10 report 156 of the above united with churches as a result of the work: men, 120 ; boys, 36 .

24 report 102,784 a total attendance at all religious meetings and Bible classes.

\section{Student Associations}

91 associations in colored institutions are in existence.

2 have been organized this year.

72 report statistics of their work.

62 report 11,360 young men, students in their institutions.

61 report 7,821 young men, students in their institutions, members of evangelical churches.

68 report a total membership of 5,081 .

66 report an active membership of 3,795 .

66 report 1,389 men serving on committees. 
30 report $\$ 1,650$ paid out last year for current expenses.

46 report 1,595 young men's meetings, with a total attendance of 94,225 .

25 report 1,234 Bible-class sessions, with a total attendance of 28,000 .

26 report 188 missionary meetings; 6 report 361 men in mission study.

43 report 253 lectures.

15 report 545 volumes in libraries.

\section{Items Common to City and Student Sections}

130 colored associations are in existence; 100 send in reports.

96 report a total membership of 10,460 .

92 report an active membership of 6,631 .

90 report working committees, with a membership of 2,689 .

54 report cash paid out for current expenses, $\$ 43,597$.

37 report libraries, containing 6,281 volumes.

28 associations employ 29 secretaries.

16 associations own buildings, valued at $\$ 201,700$.

As to the individual Young Men's Christian Associations, the following facts may be noted:

Kansas City, Mo., is arranging to put up a $\$ 10,000$ building.

The Association in Louisville, Ky., has a handsome building which cost $\$ 10,000$; of this the whites gave $\$ 7,000$ and the colored people $\$ 3,000$.

The Baltimore Association sold the old building for $\$ 3,500$ in October, 1908 , and is now in rented quarters with $\$ 3,000$ in bank toward a building fund. They spend $\$ 1,800$ a year and have a gymnasium, shooting gallery, pool table, etc.

The St. Lou is Association has a building worth $\$ 5,000$. They raised $\$ 2,100$ last year; almost entirely among Negroes.

The Chattanooga Association raised $\$ 2,600$ in 1907 ; over half of this came from Negroes.

The Knoxville Association has property valued at $\$ 3,000$ and raises $\$ 800$ a rear.

Among the most interesting associations is that at Buxton, Ta. Buxton is a colored mining town of five thousand; three-fourths of the population being colored. This is the largest association for colored people in the world and has a building for men and one for boys. They have Sunday services, Bible class, night schools, readingroom, and theatrical entertainments in a hall which seats six hundred; about 150 men and boys use the grmnasium. At night after working hours from 150 to 200 men can be found in the buildings. The total membership is 369 and the buildings and furniture are worth $\$ 40,000$.

The New Orleans Association has property worth $\$ 10,0000$.

The assuciation at Portsmouth, Va., has property worth about $\$ 5,000$.

The association in Richmond, Va., has property worth $\$ 6,000$ and a membership of 275 ; a good library of 1600 volumes; visits are made to the penitentiary and the sick, and there is a night school.

At Asheville, N. C., Mr. George W. Vanderbilt put up a building at a cost of $\$ 32,000$. It contains four storerooms, three sleeping-rooms, a hall seating 600, four office-rooms, a parlor, reading-room, and a large room for night school, with baths in the basement. This proved to be 
too heavy a burden for the colored people to support, but when Mr. Vanderbilt threatened to foreclose the mortgage on the property and meet no more deficits coming from expenditures, the colored people rallied and bought the place by paying $\$ 2,400$ in cash and securing a loan of $\$ 8,000$. It then became a regular Young Men's Christian Association, and now has the debt down to $\$ 6,000$. There is a membership of 200 and a night-school, also a library of 500 volumes and gymnasium work.

The Young Women's Christian Association has never flourished so well among the colored people, on account of social prejudice ; but separate associations are beginning to be formed now.

There is an association in St. Paul, two sectional conferences in South Carolina and Alabama, and there are the following other associations :

Alabama, seven: Talladega College, Tuskegee Institute, Selma University, State Normal School, Miles Memorial College, A. \& M. College.

Georgia, three; Spelman Seminary, Paine College, Haines Institute.

Kansas, two: The Western College, The Topeka N. \& I. Institute.

Louisiana, one: Straight University.

Mississippi, four: Southern Christian Institute, Tougaloo University, Jackson College, Alcorn A. \& M. College.

Missouri, three: Western College \& Ind.Institute, Lincoln Institute, George R. Smith College.

Arkansas, three: Philander Smith College, Branch Normal College, Arkansas Baptist College.

District of Columbia, one: Howard University.

North Carolina, one: Bennett College.

Ohio, one: Wilberforce University.

Oklahoma, one: A. \& N. University.

South Carolina, three: Claflin University, Benedict College, Allen University.

Tennessee, four: Walden University, Roger Williams University, Lane College, Knoxville College.

Virginia, one: V. N. \& I. Institute.

Pennsylvania, one: The Philadelphia Association.

New York, two: The Fifty-third Street Branch, New York city, The Lexington Avenue Branch, Brooklyn.

Minnesota, one: The St. Paul Branch.

District of Columbia, one: The Washington Association.

The branch in New York, Fifty-third Street, has a dormitory, parlors, reading-room, library, an employment bureau, and serves meals. There is also instruction in sewing, millinery, cooking, physical culture and elocution.

The branch in Brooklyn has a regular night-school with instruction in 21 industries.

The association in Washington raises about $\$ 700$ a year and has a building fund. 
Section 15. Refuges and Rescue Homes for Women. These institutions fall into two classes: those that seek to protect decent girls and those that try to reform fallen women. Among the first are a series of homes for servant girls, supported mainly by colored people.

The Phyllis Wheatley Home of Chicago reports:

The home is established to solve the problem of befriending the colored girls and women who come in to this great city seeking work, often without relatives, friends or money.

1st. By providing a comfortable home surrounded by Christian influences.

2nd. To elevate the standard of domestic service; to provide a social center for homeless girls and women, where they can improve their opportunities, be assisted in securing employment, and feel sure at all times of friendly help, mutual help and encouragement.

The home is open for the reception of visitors daily from $10 \mathrm{a} . \mathrm{m}$. to $5 \mathrm{p} . \mathrm{m}$.

Terms : \$1.25 per week for lodging. Transient, 25 cents per night.

The winter has been one long struggle to keep things going and to help the many girls and women who come to us. We feel that our work is one of practical value to any community, especially one like this great cosmopolitan city where our people come in on every train and among them many women and girls seeking to better themselves in various ways. Of the hundred or more homes established here for working girls, not one of them offers a shelter to our girls except the Beulah Home and the Erring Girl's Refuge; both of them open their doors after the first false step has been taken.

Many of our girls coming from small towns and the Southland are unused to life in a great eity and find themselves stranded and helpless, ready to fall an easy prey to the human vultures ever ready to destroy young womanhood.

Again, conditions in domestic service are vastly different from those they were familiar with in their homes, and they are labeled incompetent when often they are willing but "green," and ignorant of the ways of service in eity homes.

The Phyllis Wheatley Woman's Club, organized thirteen years ago, has always felt the importance of its mission to better community conditions. We have during those years supported a sewing-school, a day nursery in a muchneeded district, etc. Three years ago we determined to do something toward helping the stranger girl and woman especially, as well as those in our midst who needed it, to a standard of higher womanhood and usefulness.

We began the purchase of the Home at 3530 Forest avenue at a cost of thirtyfour hundred dollars, with an incumbrance of twenty-five hundred dollars. We kept it rented until May 1st, 1908, turned the rentals orer to the payment of the property until we had paid $\$ 2,029$, which includes the equity, interest on mortgage, taxes, insurance, and reduction of mortgage by $\$ 500$.

We opened the Home Mas 31st, 1908, and have never been without an inmate a single day. We have housed thirty girls, have secured employment for over one huidred, and have given encouragement, sympathy, and in a few cases financial aid, to many more. We have done very little soliciting. We have a membership of forty earnest Christian women.

A Home of this kind ought to be in every large city, and notices of the same given wide publicity in erery town and city throughout the country, in order to safeguard our women and girls.

In Indianapolis, Ind., there is a Young Colored Women's Protective Association. 
Something had to be done. There was a Young Men's Christian Association for the white boys, there was one for the colored boys; there was a Young Women's Christian Association for white girls, but there was none for the solored girls.

The work started in a four-room cottage and now they have bought a three thousand dollar house.

But the most hopeful feature of all, the most encouraging sign of the times, is that the responsibility and the burdens of the work have been borne by young women for their future development and for the benefit of other young women who might wish to share the privileges of upbuilding which this association has planned to provide. It was pioneer work, and all the hardships incident to pioneer work they have endured bravely and wonderfully. No pen can do justlce to the loyalty, to the sacrifice, to the real heroism that has been manifested by the young women interested in the support and management of this work.

It has over one hundred members, and is designed among other things :

To provide literary, musical, social and industrial centers for the pleasure and improvement of young women.

To establish training-schools in domestic science for the improvement of conditions in the home, and from which young women who prefer housekeeping or cooking may graduate.

To recognize with respect, intelligent, moral, competent, cultured workers in whatever honorable avocation engaged.

To secure for working women better hours and bring before their employers the desirability of giving their woman employes half-holidays at least during the summer months.

To maintain ar employment committee, which shall assist in procuring desirable positions for women who are out of employment.

To become acquain ted with other women who are strangers in our eity and to be helpful to them in any way possible.

To assist women desiring an education to find help along the particular lines in which they are interested.

To encourage commercial enterprise among Negroes by patronizing the same and thus to help make opportunities for other girls.

A Negro Working-Girls' Home will soon be opened in Springfield, Mass.

One in Boston, called the Harriet Tubman House, at 37 Holyoke St.,

Was established by a number of colored women of the W. C. T. U. of Boston, who have made many sacrifices for its maintenance during the past three years. On November 10th, 1904, the house was open to the public for inspection. It is designed to furnish protection and home comforts to young colored women who come to our eity from various parts of the country and at a nominal cost to them. It is the only one of this kind in our city. At present the house has accommodation for twelve young women. There is a lecture-room, parlor, sleeping-rooms, dining-room, kitchen and laundry. This work is carried on by voluntary contributions, and it is not connected with any denomination or religious sect. It is the purpose of the management to open classes in the domestic arts, such as cooking, sewing, laundering, etc., as soon as sufficient funds are in hand to carry on the work. 
The immediate need of the House is $\$ 10,000$ for the purpose of paying for and equipping a permanent building :

The House takes respectable working girls and gives them a home. It has sheltered 77 girls last year, and raises about $\$ 1,000$ a year for its support.

There are two such homes in Michigan: one in Grand Rapids which, with the aid of white friends, purchased a small building for $\$ 1,600$, partially paid for. The other, in Detrnit, was organized in April, 1906:

We have for the past two years been very successful in having millinery, dressmaking, and embroidery classes. We employed one of our race to instruct us in each class. We give ten lessons for $\$ 1.00$ in advance. Our expenses for the millinery class has been about $\$ 90.00$ or more, and dressmaking class expenses $\$ 50.00$.

This year they are trying to buy property.

One of the most extensive efforts to help colored girls is the National Association for the Protection of Colored Women, started by the white women of New York. There are local associations in New York, Philadelphia, Baltimore, Norfolk and Washington. The local work is largely or wholly in the hands of colored people and supported by contributions from both races.

The Philadelphia association is perhaps the most active. Its object is to provide a settlement and protection for migrating colored women, to study conditions and disseminate information.

Mrs. H. F. Lanning, our dock worker. daily meets the boats at the Ericsson Line (Baltimore Boat Company) and the Merchants' and Miners' Line(Charleston andGeorgia boats) bringing passengers from the Southern States. The courtesy of the boat companies is yet accorded to our worker. Following is a report of the total number of persons met during the year:

\begin{tabular}{|c|c|}
\hline 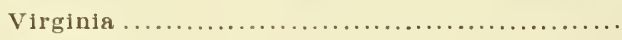 & 458 \\
\hline 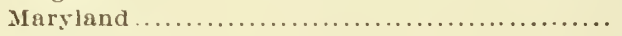 & 368 \\
\hline 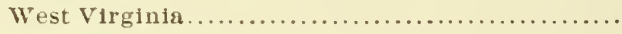 & 213 \\
\hline 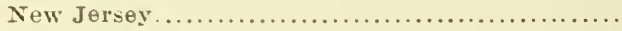 & 47 \\
\hline 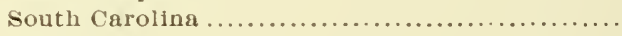 & 46 \\
\hline 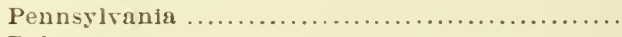 & 60 \\
\hline 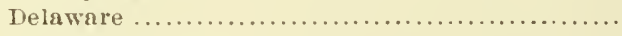 & 59 \\
\hline 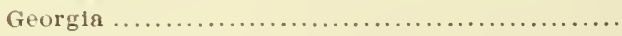 & 55 \\
\hline 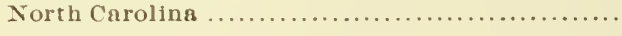 & 45 \\
\hline
\end{tabular}

Fmployment agencies are looked after, and there is a working-girls' home established in Philadelphia.

There are also working-girls' homes in Lynchburg, Va., and Richmond, Va., and a morement for one in Columbia, S. C.

Next to this work comes attempts to rescue girls who are already fallen into rice, or liable to. There is, for instance, an industrial home for colored girls at Pittsburgh, Pa., now three years old. It raises $\$ 3,350$ a year, of which $\$ 2,250$ comes from the State of Pennsylvania.

The Doreas Home Society of Yonkers, N. Y., is doing reformatory work among Negro women, and maintains a home and an employment office. 
The White Rose Mission in New. York has done considerable rescue work.

In Topeka, Kan., is a rescue home for fallen women and girls, and the Colored Hebron Rescue Association maintains a home in St. Louis.

In Kansas City, Mo., the legislature failed to decide on an industrial reform home for girls, and the Federation of Women's Clubs took up the matter and established a home in 1908, known as the Jackson County Home for Negro Girls.

Forty girls have been sent by the Court to the Home, of whom seven have been sent to homes out of the eity, six paroled by the Court, nine discharged, and sixteen are now in the Home. We feel proud of the fact that not one has attempted to escape, and at no time has it been necessary to call an officer to quiet any disturbance.

The girls are taught cooking and laundry work, the latter bringing in quite a deal of revenue to the Home. We have also tried to improve them morally and religiously, sixteen having been induced to join the church. All attend church and Sunday-school regularly. Besides this influence, the Board of Education provides us a half-day school, conducted by Miss Doshia Johnson, a very kind and earnest young woman, who has done much good toward the progress of the girls.

We feel grateful to Mr. Lee and Mr. Ross, our probation officers, for their untiring efforts for the success of the Home, and to the public for its generous support of our work. Our board of managers meets monthly to settle the accounts of the Home, and its secretary is able at a moment's notice to give a complete and accurate statement of the financial condition of the institution and its working throughout.

The income of the Home has been as follows:

\begin{tabular}{|c|c|}
\hline County Court ( $\$ 10$ per month for each inmate... $\$$ & 82678 \\
\hline Juvenile Improvement Association............ & 24000 \\
\hline 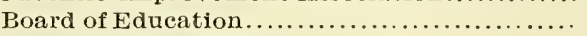 & 753 \\
\hline 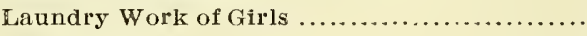 & 135 \\
\hline 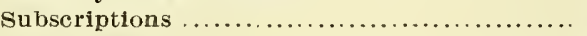 & \\
\hline
\end{tabular}

In Philadelphia there is a Home for the Homeless where any woman may apply for temporary aid.

In Los Angeles, Cal., there is a Sheltering Arms Home:

Its doors are open night and day to any homeless woman, girl or child in need of shelter. We are renting, as yet, and caring for twelve persons at the present. We have sheltered fifty-six since opening, October 28, 1907. The growth has been slow because the people have not felt the real need of such an institution. We are beginning to awaken now, and are looking forward to great progress in the near future. We have donated five lots and a small three-room house which we hope to improve this fall.

In Washington there is a Home for Friendless, and also a National Association for the Relief of Destitute Women and Children supported by the Government at the cost of $\$ 10,000$ a year, but conducted entirely by colored women. It had 103 women and children in 1907.

One woman, Mrs. Elizabeth MeDonald, has been probation offleer in Chicago, and does considerable lecturing on the subject of rescue work among women and children. 
Section 16. Social, Literary and Art Clubs. All over the country there are a number of private and some public clubs among the colored people devoted primarily to litelature or some form of art work. They are the remains of the more flourishing literary societies of ante bellum days in the free Negro settlements, but have changed considerably in character and kind of work.

The Friday Afternoon Study Club of Cleveland, O., consists of women who assemble once in two weeks to listen to papers and the discussions of general subjects. As, for instance, in 1905-06 they took the history of the United States and discussed different periods in sixteen different meetings, taking up not simply the formal history but the rise and fall of slave power, the development of American literature and art, the development of education, etc.

The Booklovers' Club of Washington, D. C., discussed the same year the principal religions of the earth and their effect on civilization. They held two meetings a month for seven months and took up the religion of Egypt and other ancient places, including Brahminism, Buddhism, Judaism, including a comparison of Jews and Negroes, Mohammedanism, Roman Catholicism, Protestantism, with discussions of the Negro and the Catholic Church and of American Negro religion.

Nearly all the larger churches throughout the United States have one or more literary societies connected with them; perhaps the most noted of these church literary societies is the Bethel Literary and Historical Association of Washington, D. C., organized in 1881 and commanding large audiences. Probably few organizations have had a more distinguished list of speakers, including Frederick Douglass, J. C. Price, John M. Langston, Alexander Crummell, Dr. E. W. Blyden, George W. Williams, Senator Blair, Richard T. Greener, and others.

Examples of some of the present societies follow:

The Dunbar Reading Circle of Newport News, Va., studies Negro history.

The Bowen Reading Circle of Washington, D.C., meets twice a month to read different authors.

The Royal Club of Houston, Tex., has a literary programme once a month and spends the rest of their time in charity work.

The Ladies' Reading Circle of Dallas, Tex., pursues certain lines of reading from year to sear.

The Ladies' Literary Digest Club of Danville, Ky., is to encourage the reading of race literature and current events, and contribute to good causes.

The Macon Art and Social Club of Macon, Ga., consists of married women organized to do fancy work, and does some charity work also.

The West Indian Literary Club of Cambridge, Mass., does both literars and charitable work.

The Union of Haverhill, Mass., conducts a literary course. 
The Detroit Study Club of Michigan is studying the lives of English and American poets.

The Scotia Reading Club of Jersey City, N. J., encourages the study of literature and maintains a scholarship at Scotia Seminary.

The Minervia Club of Cleveland, Ohio, is literary and musical, with some charitable work.

The American Girls' Culture Club of Newport, R. I., writes:

The American Girl's Culture Club was organized January 13, 1905, by Mrs. Bessie Jamison. There are at present twenty-two members. Our object is to work along various lines of charity and to help the Colored old Folk's Home and the Working-Girls' Home in Providence. The first week in June the club is planning to give a star concert and the proceeds will be sent to a young colored man who is working his way through Brown University in Providence. Nearly all the girls in our club are talented, and very often the churches call upon us to help them out in their entertainments. We send flowers, fruits and other delicacies to the sick. We have made a number of visits to the hospital. We go and see the blind, and read to them. Eastertime we took several potted plants to a number of old ladies. In the last two or three weeks we have sent two large baskets of groceries to two poor old women. The club has given several dramas and concerts, and all proved to be successful. The ministers and all the churches seem to take a great interest in us. We have been very lucky in not losing any members by death. Nearly all of the girls attend the High School; some have graduated and are away to college.

In several cities there are organizations which maintain lectures and discussions on Sunday afternoon specially for mell. Among these are the Men's Forum of Cambridge, Mass., the Sunday Forum of Minneapolis, Minn., and the Young Men's Christian Sunday Club, of Savannah, Ga. This latter club reports:

Its purpose is for the economic and hygienic development of Negroes. They do their work: $(a)$ by having Sunday meetings at which men of ability give lectures; $(b)$ they issue literature on hygiene to afflicted sections of the city; they make contributions to the poor, sometimes to the colored hospital. Any one willing to take part may become a member; no monthly fees required. Its finances come from collections from those who attend.

Various eities maintain regular lecture bureaus. One of the most successful of these is the People's Lecture Association of Little Rock, Ark. The following is a report of this organization:

Organization effected November 11, 1903, with about twenty-five members; serenty members in 1909.

Dues, one dollar per year, in quarterly payments.

During six years of its existence it has had forty-two lectures, two concerts by local talent, two concerts by professional talent, and one stereopticon lecture.

We have raised about $\$ 500$.

Our earlier lecturers were colored college presidents of the city; later, white ministers of the city, politicians, teachers, educators of standing, not forgetting two lectures by Father Lucy, of Pine Bluff (white Catholic priest and writer of newspaper articles in State papers, advocating better treatment of Negroes), nor omiting Rabbi Wolsey (Jewish Priest, travelling orator; now 
of Cincinnati), nor Professor Dayne, State Superintendent of Public Instruction.

Our colored lecturers embrace names widely known and appreciated. Of these are Prof. W. E. Burghardt DuBois, Atlanta University ; Prof. Wm. Pickens, Talladega College; Mrs. Mary C.Terrell, Hon. Edward Morris, of Chicago; Hon. J. T. Settles, lawyer of Memphis, Tenn., Archdeacon G. Alexander McGuire, of Cambridge, Mass.; Rev. Maximo Duty, of Memphıs, Tenn.; Rev. D. LeRoy Ferguson, of Louisville, Ky.; Prof. Kelley Miller, Washington, D. C.

There are a number of small men's clubs like the Monday Club of Atlanta, Ga., and Advance Club of Birmingham, Ala. These are chiefly social clubs, but are also places of discussion and centers of various civic movements. For instance, members of the A tlanta Monday Club were largely called upon in the Atlanta riot to join with the whites in reconstruction.

Many social clubs are formed with the distinct purpose of beautifying and bettering social life. The Owl Club of Little Rock, Ark., consisting of nineteen married couples, was organized in 1894 . Its object is to "uplift our race socially, and we have succeeded in bettering it morally as well."

There are a number of so-called art clubs whose object is chiefly social, and who do some drawing and painting and embroidery. They are chiefly valuable in keeping alive and encouraging the love for beautiful things; although the actual work accomplished is usually small and unimportant.

Silver Spray Art Club of Houston, Tex., is trying to beautify the homes of its members and also do some charitable work.

The most important developments in the line of art have been naturally toward music. Nearly all the large churches have organized choirs, and there are numbers of amateur musical associations, instrumental and vocal.

The work of Mr. Coleridge-Taylor, of England, led to the establishment of the Coleridge-Taylor Choral Society, in Washington, D.C. This society had a chorus of 200 ; among its patrons were Reginal DeKoven, Eugene E. Stephens, Henry Handzer, Lieutenant Santelmann.

It was organized in 1901 (incorporated 1903), under the stimulus of a proposed risit to Washington of the eminent composer. In a conference of our more prominent musicians, which met at the home of Mrs. A. F. Hilyer, it was discorered that the formation of a choral society among the colored singers of Washington had long been in the minds of many of them, and only needed the stimulus of the proposed visit of the composer and the opportunity to sing "Hiawatha" to give it tangible shape and permanent form. Its object is to develop a wider interest in the masterpieces of the great composers and especially to diffuse among the masses a higher musical culture and appreciation of works that tend to refine and elevate.

Since its organization the society has rendered "Hiawatha" on seven different occasions-four tjmes in Washington, twice in Baltimore, and once in Philadelphia at the Academy of Music. It has also rendered Mr. S. ColeridgeTaylor's "Atonement" and the Choral Ballads (the latter having been dedicated to the society by the composer) and other compositions. 
In Norember, 1904, the society had Mr. S. Coleridge-Taylor as its special guest, when it gave a Musical Festival consisting of three great concerts-two in Washington and one in Baltimore-rendering Hiawatha and the Choral Ballads under the direction of the composer, with the U. S. Marine Band Orchestra of 52 pieces accompanying, and other selections directed by Prof. John T. Layton. These concerts were attended by prominent musicians (white and colored) not only from this city, but from New York, Philadelphia, Boston, Baltimore, Chicago, Richmond, and other cities.

The most remarkable effort, perhaps, is the Foreign Scholarship Association established by Mme. E. Azalia Hackley. Mrs. Hackley, who herself has an unusual voice and was trained abroad, said in taking up her work in 1907 :

I thoroughly believe that there is a future for colored musicians abroad, providing they take rank with white artists. I may not live to see it, but even in ten years, if something is done to encourage such a condition, I believe that several first-class companies-not coon shows-could have seasons in various countries. I also believe that white managers will engage colored artists, providing they can sing in foreign languages. I believe that there could even be colored managers abroad within the next ten years, but they would be obliged to offer real attractions.

If we encourage our young people generally throughout the country, every five or six years, some one of them will leap out of the circle of mediocrity and push his way to the front, and perhaps represent us musically as we have never been represented.

If the colored musicians in each place would unite as enthusiastically as people do to start a new church, or establish a lodge, there could be some one helped each year.

Who is doing anything for a colored genius? Well, of course, the race is comparatively poor, but there are some wealthy ones, and we could help a couple a year, at least, if we tried.

I heard abroad of about six students whom Mr. Schwab, the steel magnate, is helping. He does not even know the beneficiaries. Mr. Rockefeller and Mrs. Vanderbilt are educating several each, and many others are helping talented people.

Thereupon Mrs. Hackley established what she ealled the Foreign Scholarship, and induced two hundred or more colored people to contribute a scholarship of two or three hundred dollars a year. She then took a trip through the Snuth, and reported an orchestra of thirty members in Richmond,Va., and a festival; a remarkable soprano at Atlanta University, and a good violinist; fine choral work at Tuskegee; a very competent piano teacher at Montgomery; an amateur cornetist at Mobile; a chorister in New Orleans and four exceptional voices, and a tenor soloist at Jacksonville. In the West she found a good soprano at Harrisburg, chorister in Pittsburgh, three violinists in Detroit and Chicago, a good soprano voice in Chicago together with a musicalstudy club, a good musical director in Kansas City, a rare contralto in Omaha, a chorus of thirty-five voices in Denver, a good baritone in Colorado Springs, a pianist in Oakland, Cal., and a study club in Los Angeles. 
In the pursuance of this plan Mrs. Hackley has sent her first beneficiary abroad during 1908-9 in the person of Clarence C. White, a violinist of rare ability; the next beneficiary is to be Carl R. Diton; three hundred dollars is to be raised for him.

In her last report Mrs. Hackley says:

In June I finished the last payment of the five hundred dollars I had promised to Mr. Clarence Cameron White, to assist him in his studies abroad for one year. Mr. White sailed for London in June, 1908.

It has been a difficult task to collect this amount, but it has been accomplished, and the scholarship establishes a precedent. I am highly gratified with all results. If those who have contributed could understand how arduously Mr. White has worked, and how much he has improved in his playing, they would-be as pleased as I am. If he had to return at this date, he will have profited to a remarkable extent, and the money has been well spent.

To have one colored artist presented abroad every five years would cost less than $\$ 5,000$, an average of $\$ 1,000$ a year. What a pittance this is if scores one point in favor of ten millions of people. One department store in any large eity expends that much in less than a week for advertising, because the results of advertisement are evident.

How can the race expect the world to believe that it has rare musical talent, the one line in which it can excel if given opportunity, if the fact is not continually advertised and evidence produced? Must there be no change of opinion because of a few dollars that might be easily given?

Another interesting musical association is the Viotti Association of Boston. Its founder says:

I went from house to house one day and saw as many mothers as I possibly could find at home, told them what my object was, that ] wanted them to help me in getting the boys and girls off the streets at night and give them something to do at home, something all colored people, as a rule, are very fond of, and that is music. I started out with fire other women and we organized a club called the Tiotti Club of Boston. For one year it grew to fifteen, then I entered the club into the Northeastern Federation of Women's Clubs of New England, and we now number twenty-five. The club was named for Henry Tiotti, of London, a professor of music. We have a Junior Department of twenty boys, who are organized into a brass band and orchestra. They are doing nicely. It is conducted by a colored woman of my club. Last year we raised one hundred and twenty-nine dollars from concerts given by the boys. I paid $\$ 150$ for the instruments. We give the instruments to the poorer boys who are not able to pay for them.

There is one National Association which seeks to encourage literature and art among Negroes. This is the American Negro Academy, founded by Alexander Crummell in 1897. Its objects are "the promotion of literature, science and art; the culture of a form of Intellectual Taste; the fostering of Higher Education; the publication of scholarly work; the defense of the Negro against ricious assaults."

It has a limited number of selected members and has published thirteen pamphlets on Sociological and Historical subjects. 
Section 17. Literature and Newspapers. Only a brief sketch of the attempt to better social conditions by means of newspapers, books and periodicals can here be attempted.

As early as the eighteenth century, and even before the Revolutionary War, the first voices of Negro authors were heard in the United States.

Phyllis Wheatley, the black poetess, was easily the pioneèr, her first poems appearing in 1773 , and other editions in 1784 and 1793 . Her earliest poem was in memory of George Whitefield. She was followed by the Negro, Olaudah Equiano-known by his English name of Gustavus Vassa-whose autobiography of 350 pages, published in 1787, was the beginning of that long series of personal appeals of which Booker $\mathrm{T}$. Washington's Up From Slavery is the latest.

Benjamin Banneker's almanacs represented the first scientific work of American Negroes, and began to be issued in 1792.

Coming now to the first decades of the nineteenth century we find some essays on Freedom by the African Society of Boston, and an apology for the new Negro church formed in Philadelphia. Paul Cuffe disgusted with America wrote an early account of Sierra Leone, while the celebrated Lemuel Haynes ignoring the race question dipped deeply into the New England theological controversy about 1815. In 1829 came the first full-voiced, almost hysterical, protest against slavery and the color line in David Walker's Appeal, which aroused Southern legislatures to action. This was followed by the earliest Negro conventions which issued interesting minutes, and a strong appeal against disfranchisement in Pennsylvania.

In 1840 some strong writers began to appear. Henry Highland Garnet and J. W. C. Pennington preached powerful sermons and gave some attention to Negro history in their pamphlets; R. B. Lew is made a more elaborate attempt at Negro history. Whitfield's poems appeared in 1846, and William Wells Brown began a career of writing which lasted from 1847 until after the war. In 1845 Douglass's Autobiography made its first appearance, destined to run through endless editions up until the last in 1893. Moreover it was in 1841 that the first Negro magazine appeared in America, edited by George Hogarth and published by the A. M. E. Church.

In the fifties William Wells Brown published his "Three Years in Europe"; James Whitfield published further poems, and a new poet arose in the person of Frances E. W. Harper, a woman of no little ability who is still alive; Martin R. Delaney and William Nell wrote further of Negro history, Nell especially making valuable contributions to the history of the Negro soldiers. Three interesting biographies were added in this decade to the growing number: Josiah Henson, Samuel G. Ward and Samuel Northrop; while Catto leaving general history came down to the better known history of the Negro church.

In the sixties slave narratives multiplied, like that of Linda Brent, while two studies of Africa based on actual visits were made by Robert Campbell and the revered Alexander Crummell; William Douglass 
and Bishop Daniel Payne continued the history of the Negro church, while William Wells Brown carried forward his work in general Negro history. In this decade, too, Bishop Tanner began his work in Negro theology.

Most of the Negro talent in the seventies was taken up in politics; the older men like Bishop Wayman wrote of their experiences. William Wells Brown wrote the Rising Son, and Sojourner Truth added her story to the slave narratives. A new poet arose in the person of A. A. Whitman, while James M. Trotter was the first to take literary note of the musical ability of his race. Indeed, this section might have been begun by some reference to the music and folklore of the Negro race; the music contained much primitive poetry and the folklore being one of the great contributions to American civilization.

In the eighties there are signs of unrest and different conflicting streams of thought. On the one hand the rapid growth of the Negro church is shown by the writers on church subjects like Moore and Wasman. The historical spirit was especially strong. Still wrote of the Underground Railroad; Simmons issued his interesting biographical dictionary, and the greatest historian of the race appeared when George W. Williams issued his two-volume history of the Negro race in America. The political turmoil was reflected in Langston's Freedom and Citizenship, Fortune's Black and White, and Straker's New South, and found its bitterest arraignment in Turner's pamphlets; but with all this went other thought: a black man published his first Greek lessons, Bishop Payne issued his Treatise on Domestic Education, and Stewart studied Liberia.

In the nineties came histories, essays, novels and poems, together with biography and social studies. The history was represented by Parne's History of the A. M. E. Church, Hood's History of the A. M. E. Zion Church, Anderson's sketch of Negro Presbyterianism and Hagood's Colored Man in the M. E. Church; general history of the older type by R. L. Perry's Cushite, and the newer type in Johnson's History and DuBois's Suppression of the Slave Trade, while one of the secret societies found their historian in Brooks; Crowman's essays appeared and Archibald Grimke's biographies. The race question was discussed in Frank Grimke's published Sermons, while social studies were made bs Penn, Wright, Mossell, Crummell, DuBois, Majors, and others. Most notable, howerer, was the rise of the Negro novelist and poet with national recognition; Frances Harper was still writing and Griggs began his racial novels, but both of these spoke primarily to the Negro race; on the other hand, Chesnutt's six novels and Dunbar's inimitable works spoke to the whole nation.

Since 1900 the stream of Negro writing has continued: Dunbar has found a worthy successor in the less-known but more carefully cultured Braithwaite; Booker T. Wasbington has given us his biography and Story of the Negro; Kelly Miller's trenchant essays hare appeared in book form and DuBois's Souls of Black Folk and John Brown; Sin- 
clair's Aftermath of Slavery has attracted attention, as have the studies made by Atlanta University. The forward movement in Negro music: is represented by Frederick J. Work in one direction and Rosamond Johnson in another.

On the whole the literary output of the American Negro has been both large and creditable, although, of course, comparatively little known; few great names have appeared and little work that could be called first-class, but this, of course, is not a peculiarity of Negro literature.

\section{A Chronological List of Some Notable Works in Negro Literature}

Phyllis Wheatley-Poems on various subjects, religious and moral. 1773. 8vo.

Equiano, Olaudah (Gustarus Vassa)-Autobiography. 1787. $350 \mathrm{pp.}$

Benjamin Banneker-Alnianaes, 1792-1806.

African Society. Essay on Freedom. Boston, 22 pp. 1808.

Act of Incorporation, Causes and Motives of the African Episcopal Church. Philadelphia, 1810.

Paul Cuffe-Brief Account of Sierra Leone. New York. 12 pp. 1812.

Lemuel Haynes-Sermons. 1815(?).

Walker, David-Appeal, in four articles, together with a Preamble to the Colored Citizens of the World, etc. 66 pp. Boston, Mass. 1829.

Minutes of the First Annual Courention of the People of Color Philadelphia. 1831 Pamphlet.

Appeal of forty thousand colored citizens threatened with disfranchisement to the people of Pennsylvania. Phila., 1838. $18 \mathrm{pp} .8 \mathrm{vo}$.

Lee, Jarena-Journal. Oincinnati, 1839. 24 pp. $12 \mathrm{mo.}$

J. W. C. Pennington-Origin and History of the Colored People. 1841. 100 pp.

African M. E. Church Magazine. (George Hogarth.) 1811.

Lewis, Robert Benjamin-Light aud Truth, etc. Boston, 1844.400 pp. $16 u 10$.

Douglass-Autobiography, 1845 .

Whitfield's Poems, 1846.

Brown, William Wells-Narrative of a fugutive. Boston, 1847. $110 \mathrm{pp} .16 \mathrm{mo}$.

Garnet, Henry Highland-The Past and Present Condition and the Destiny of the Colored Race. Troy, 1848. 29 pp. 8vo. Plates.

W. W. Brown-Three Years in Europe. London, 1852.

W. W. Brown-Sketches of Places and People Abroad. New York, 1855.

Martin R. Delaney-Condition, Elevation, Emigration and Destiny of the Colored People of the United States. Phila., 1852. 215 pp. $12 \mathrm{mo.}$

James M. Whitfield-Poems. America, and other poems. Buffalo, 1853.

Harper, Frances E. W.-Miscellaneous poems. Boston, 1851.

William Cooper Nell-The Colored Patriots of the American Revolution. Intro. by H. B. Stowe. Boston, 1855. $396 \mathrm{pp.} 12 \mathrm{mo}$.

Ward, S. G.-Autobiography of a Fugitire Negro. London, 1855.

Catto, W. T.-History of the Presbyterian Movement. Phila., 1857. 8vo. A semicentecary discourse and history of the first African Presbyterian church, Phila., May, 1857, from its organization, including a notice of its first pastor, John Gloucester; also appendix containing sketches of all the colored churches in Philadelphia.

Henson, Josiah (Uncle Tom)-Father Henson's story. Boston, 1858.

Twenty Years a Slave. Northrup. 1859.

Incidents in the Life of a Slave Girl (Linda Brent). 1861.

Robert Campbell-A Pilgrimage to my Motherland. Phila., 1861.

Orummell, Alexander-The Future of Africa. 1862.

Douglass, William-Annals of St. Thomas's First African Ohureh. Philadelphia, 1862. $172 \mathrm{pp}$. 8vo.

Brown, William Wells-The Black Man, his Antecedents, etc. New York, 1863. $288 \mathrm{pp} .12 \mathrm{mo}$.

Payne, D. A.-The Semi-Centenary and the Retrospection of the A. M. E. Uhurch. 1866. 
Brown, William Wells-The Negro in the American Rebellion. Boston, 1867. 380 pp. 8ro.

Tanner, Bishop Benjamin T.-An Apology for African Methodism. Baltimore, 1867. 468 pp. 8 vo.

Cyclopedia of African Methodism. Bishop Wayman.

Brown, William Wells-The Rising Son. Boston, 1874 (1873). 12mo. Portrait.

Truth, Sojourner-Narrative. Boston, 1875.

Whitman, A. A.-Not a Man and Yet a Man. Springfleld, O., 1877.

Trotter, James M.-Music and some highly musical people. Boston, 1878. 353, (1) $152 \mathrm{pp} .12 \mathrm{mo}$.

Moore, J. J.-History of the A. M. E. Zion Church. York, Pa., 1880.

Williams, Geo. W.-History of the Negro race in America from 1619 to 1880. New York, 1883. 2 vols. 850.

Wayman, A. W.-My recollections of A. M. E. Ministers. Philadelphia, 1881. 250 pp. 8vo.

Scarborough, W. S.-First Greek Lessons. New York, 1881. 150 pp.

Langston, J. M.-Freedom and Citizenship, 1882. 286 pp.

Still, Wm.-The Underground Railroad. Phila., 1883.

Fortune, T. Thomas-Black and White. New York, 1881.

Turner. H. M.-The Black Mlan's Doom. 1894, 1896. 90 pp.

Turner, H. M.-Methodist Polity, or the Genius and Theory of Methodism. Philadelphia, 1885.

Payne, Daniel A.-A Treatise on Domestic Education. Cincinnati, 1885.

Scarborough-The Birds of Aristophanes. 1856. $36 \mathrm{pp.}$

Stewart, T. Mc.-Liberia, the Americo-African Republic. New York, 1886.

Simmons, Wm. Johnson-Men of Mark: eminent, progressive, rising. Cleveland, 1887 1141 pp. 850.

Straker, D. Augustus-The New South Investigated. Detroit, 1888.

Hagood, L. M.-The Colored Man in the Methodist Episcopal Church. 1890. Cincinnati.

Gaines, W. J.-African Methodism in the South. Atlanta, 1890.

Recollections of Serenty Years-Bishop D. A. Payne.

Jamieson, Dr.-Minden Armais, the man of the new race. Phila., 1890. 110 pp.

Crummell, Alexander-Africa and America. Springfield, 1881. $466 \mathrm{pp} .8 \mathrm{vo}$.

"Aunt Lindy"-Victoria Earle.

Penn, Irvine Garland-The Afro-American Press and its Editors. Springfield, 1811. 565 pp. $12 \mathrm{mo}$.

Johnson, Edward A.-A School History of the Negro Race in America from 1619 to 1890, with a short introduction as to the origin of the race; also a short sketch of Liberia. Raleigh, 1891 ,

Payne, Daniel A.-History of the A. M. E. Church. Nashville, 1891. 498 pp.

Grimke, Archibald H.-William Lloyd Garrison. New York, 1891.

Grimke, Archibald H.-Charles Sumner. New York, 1892. 515 pp. 8vo.

Harper, Frances E. W.-lola Leroy: a norel. 3d ed. Phila., 1892. 281 pp.

Perry, Rufus L.-The Cushite. Springfield, 1893.

Majors, M. A.-Noted Negro Women. Chicago, 1893.

Brooks, O. H.-Manual and History of the Grand United Order of Odd Fellows. Philadelphia, 1863. $260 \mathrm{pp}$. 850.

Smith, Mrs. Amanda-Autobiography of Amanda Smith. Ohicago, 1893.

Mossell, Mrs. N. F.-The Work of Afro-American Women. Phila., 1894.

Jones, Robert-Fifty Years in the Lombard Street Central Presbyterian Church. Philadelphia, 1504.

Wright, Richard R.-Brief Historical Sketch of Negro Education in Georgia. Savannah, lsa4.

Hood, W. J.-History of the A. Il. E. Zion Church. New York, 1895.

W. H. Crogman-Talks for the Times. Atlanta, 1896.

DuBois, W. E. B.-Suppression of the Slare Trade. New York, 1896.

Anderson, Matthew-Presbyterianism and its relation to the Negro. Phila., 1897.

Griggs, Sutton E.-lmperium in Imperio. Cincinnati, 1899. 
Ohesnutt, Oharles W.-

The Conjure Woman. Boston, 1899.

Frederick Douglass. Boston, 1899.

The House Behind the Cedars. Boston, 1900.

The Marrow of Tradition. Boston, 1901.

The Wife of his Youth. Boston, 189.

Grimke, Francis J.-The Lynching of Negroes in the South. Washington, 1899.

DuBois, W. E. B.-The Philadelphia Negro. Phila., 189. 520 pp.

Dunbar, Paul Lawrence-The Sport of the Gods. New York, 1901.

Atlanta University Publications-The Oollege-bred Negro. Atlanta, 1900.

Atlanta University Publications-The Negro Artisan. Atlanta, 1902.

Washington, B. T.-Up from Slavery. New York, 1901.

Penn, I. G., and J. W. E. Bowen, Editors-The United Negro; His Problems and His Progress. Containing the Addresses and Proceedings of the Negro Young People's Christian and Educational Congress, held August 6-11, 1902. Atlanta, 1902.

Gibbs, M. W.-Shadow and Light. Washington, 1902.

Wright, R. R.-Negro Companions of the Spanish Explorers. From "American Anthropologist," vol. 8. 1902.

Work, Frederick J.-New Jubilee Songs, as sung by the Jubilee Singers of Fisk University. 1902.

DuBois, W. E. B.-The Souls of Black Folk, Chicago, 1903.

Atlanta University Publications-The Negro Church. Atlanta, 1903.

The Negro Problem-A series of articles by representative Negroes of to-day. New York, 1903.

Braithwaite-Poems and Anthologies.

Grimshaw, Wm. H.-Official History of Freemasonry, etc. New York, 1903.

Cromwell, John W.-The Early Negro Convention Movement. Washington, 1904. (The American Negro Academy.)

Sinclair, William A.-The Aftermath of Slavery, ete., with an introduction by T. W. Higginson. Boston, 1905.

Miller, Kelly-Race Adjustment. 1908.

Washington, B. T.-Story of the Negro. 1910.

\section{Turning now to the newspapers we quote from L. M. Hershaw:}

Negro journalism in the United States had its origin in the aspiration for freedom. The first Negro newspaper in the United States was begun in New York city, March 30,1827 , and was called The Journal of Freedom. Its editor was John B. Russworm, a graduate of Dartmouth College of the class of 1826, perhaps the first Negro to receive a degree from an American institution of learning. Associated with him in the editing was the Rev. Samuel E. Cornish, a controversialist of no mean powers.

This journal had an existence of but three years, and other attempts by Negroes to publish newspapers failed of notable success until Frederick Douglass started The North Star at Rochester, N. Y., in 1847. The name was subsequently changed to Frederick Douglass's paper, and Mr. Douglass continued it up to the opening of the Civil War. For length of life, extent of circulation, ability of matter contributed and commanding talents of its editor, the publication was one which occupies a conspicuous chapter in the history of Negro journalism.

From these beginnings the Negro newspaper has grown until to-day there are over three hundred periodicals published, most of which are in the form of tveekly papers. Since the establishment of the Journal of Freedom in 1827 thousands of Negro journals have lived and died. 
Among these papers the most notable was the Voice of the Negro, an excellent magazine which lasted several years. At different times small Negro daily papers have been started. The only surviving one at present seems to be the Daily Metropolitan of Dallas, Tex. At present there have been received in this office specimen copies of 185 papers and 9 magazines. Besides these we have the names of 76 other weekly papers which either are being published or have been until quite recently.

The 185 papers actually received have been tabulated according to the year of founding, the number of pages, the size of the page and the number of columns of "live matter." i. e., of matter actually set up in type by the paper each week and not received in printed form from some printing or advertising agency :

\section{Name}

Christian Recorder

Southwestern Christian Advocate Christian Index

Star of Zion

Afro-American Presbyterian

The Washington Bee

Georgia Baptist

Western star

Baptist Vanguard

The World

Pioneer Press

Gazette

Normal Index

A ppeal

Southern Letter

Sarannah Tribune

Philadelphla Tribune

Brotherhood

Orusader

Florida Sentinel

New York Age

The Light

The Freeman

Steelton Press

Tuskegee Student

New Light

Statesman

Southern Christian Recorder

Baptist Leader

Ohristian Banner

The Ohristian Hope

Dallas Express

Griffin Echo

Oklahoma Guide

People's Recorder

Oklahoma safeguard

Iowa Bystander

Baptist Truth

Plaindealer

Weekly Express

Charleston Messenger

The Standard

The Journal

Seattle Republican

Western Outlook

\section{Published}

Philadelphia

New Orleans, La.

Jackson, Tenn.

Charlotte, N. C.

Charlotte, N. C.

Washington, D. C.

Augusta, Ga.

Houston, Dallas, Tex.

Little Rock, Ark.

Indianapolis, Ind.

Martinsburg, W.Va.

Oleveland, O.

Normal, Ala.

St. Paul, Minn.

Tuskegee, Ala.

Sarannah, Ga.

Philadelphia

Oincinnati, $\mathrm{O}$.

Baltimore, Md.

Pensacola, Fla.

New York

Vicksburg, Miss.

Indianapolis, Ind.

Steelton, Pa.

Tuskegee, Ala.

Edwards, Miss.

Denver, Col.

Columbus, Ga.

Birmingham, Ala.

Philadelphia

Demopolis, Ala.

Dallas, Tex.

Griffin, Ga.

Guthrie, Okla

Orangeburg, S. C.

Guthrie, Okla.

Des Moines, Ia.

Cairo, III.

Palestine, Tex.

Moblle, Ala.

Oharleston, S. O.

Lexington, $\mathrm{Ks}$.

Huntsrille, Ala.

Seattle, Wash.

San Francisco, Los Angeles and Oakland, Oal. 1894
Year Pp. L.M. Size

$\begin{array}{cccc}1852 & 8 & 36 & 15 \times 22 \\ 1866 & 16 & 42 & 11 \times 15 \\ 1870 & 16 & 32 & 9 \times 13 \\ 1877 & 8 & 27 & 12 \times 21 \\ 1878 & 4 & 11 & 16 \times 22 \\ 1879 & 8 & 151 / 2 & 15 \times 22 \\ 1879 & 8 & 23 & 13 \times 20 \\ 1881 & 8 & 10 & 15 \times 22 \\ 1881 & 8 & 19 & 13 \times 20 \\ 1881 & 8 & 11 & 15 \times 22 \\ 1882 & 4 & 111 / 2 & 11 \times 20 \\ 1883 & 4 & 10 & 18 \times 24 \\ 1883 & 4 & 13 & 11 \times 16 \\ 1884 & 4 & 8 & 18 \times 24 \\ 1881 & 4 & 7 & 9 \times 12 \\ 1885 & 8 & 13 & 15 \times 22 \\ 1885 & 8 & 24 & 15 \times 24 \\ 1886 & 8 & 101 / 2 & 15 \times 22 \\ 1856 & 8 & 51 / 2 & 15 \times 22 \\ 1886 & 8 & 15 & 15 \times 22 \\ 1887 & 8 & 33 & 16 \times 201 / 2 \\ 1887 & 4 & 7 & 18 \times 24 \\ 1887 & 8 & 23 & 15 \times 22 \\ 1888 & 4 & 2 & 18 \times 24 \\ 1888 & 4 & 91 / 2 & 11 \times 16 \\ 1888 & 8 & 121 / 2 & 15 \times 22 \\ 1888 & 16 & 25 & 11 \times 15 \\ 1889 & 4 & 22 & 18 \times 23 \\ 1884 & 4 & 91 / 2 & 15 \times 22 \\ 1889 & 4 & 20 & 18 \times 24 \\ 1891 & 4 & 6 & 15 \times 22 \\ 1892 & 8 & 18 & 18 \times 24 \\ 1892 & 4 & 21 / 2 & 18 \times 24 \\ 1892 & 4 & 4 & 18 \times 24 \\ 1892 & 4 & 20 & 15 \times 22 \\ 1893 & 4 & 12 & 18 \times 24 \\ 1893 & 4 & 15 & 18 \times 24 \\ 1894 & 4 & 71 / 2 & 18 \times 24 \\ 1891 & 8 & 6 & 15 \times 21 \\ 1894 & 6 & 11 & 15 \times 22 \\ 1894 & 4 & 13 & 18 \times 24 \\ 1894 & 4 & 9 & 18 \times 24 \\ 1894 & 4 & 12 & 15 \times 22 \\ 1894 & 8 & 8 & 11 \times 16 \\ & & & \\ 1894 & 4 & 10 & 18 \times 24 \\ & & & \end{array}$


Name

Rock Hill Messenger Colored Citizen

Adrance Citizen

Detroit Reformer

The Reformer

Broad Ax

Odd Fellows' Journal

The Adrance

Recolder

The Educator

Taborian Visitor

Enterprise

The Helping Hand

Louisiana Baptist,

Informer

Oakland Sunshine

News-Enterprise

Nashville Clarion

Weekly Gazette

dity Times

Mission Herald

National Protest

Texas Freeman

Western Enterprise,

Plaindealer

Baptist Seutinel

Durham Reformer

Kentucky Standard

Iissionary Seer

Independent

Southern Reporter

Kentucky Reporter

Adrocate.

Western Messenger

The Demonstrator

St. Luke Herald

Florida Repolter

American Star

National Star

Pythian Monitor

Bluff City News

Friendship Banner

Wilkes-Barre Advocate

The Star

The courant

Professional World

The Guardian

The Torchlight

Florida Labor Temple

Baptist Rival

Industrial Era

Seattle Searchlight

The Truth

Missionary Presbyterian

Portland Àdvocate

Vox Populi

Fisherman's Net,

The Forum

Cleveland Journal

Southern Age

The Echo

The Signal

Birmingham Reporter

Illinois Idea

National Watchman

The Defender

The Adrocate

Springfleld Leader

Interstate Reporter

Staunton Reporter

Beaufort County News

Boley Progress

Florida Standard

Negro Fortune Teller.

Atlanta Justice

Colorado Times

The Messenger
Published

Rock Hill, S. C.

Memphis, Tenn.

Springfield, I1l.

Detroit, Mich.

Richmond, Va.

Ohicago, Ill.

Philadelphia, Pa.

Jamestown, N.C.

Indianapolis, Ind.

Huntsville, Ala.

Little Rock, Ark

Omaha, Neb.

Paris, Tex.

Alexandria, La.

Urbana, 0 .

Oakland, Cal.

Shreveport, La.

Nashville, Tenn.

Metropolis, Ill.

Galveston, Tex.

Louisville, Ky.

St. Joseph, Mo.

Houston, Tex.

Colorado'springs

Topeka, Kan.

Raleigh, N. C.

Durham, N.C.

Lonisville, Ky.

Philadelphia.

Sarannah, Ga.

Charleston, S. O.

Owensboro, Ky.

Charleston, W. Va.

Macon, Jefferson City

and St. Iouis, Mo.

Mound Bayou, Miss.

Richmond, Va.

Tampa, Fla.

Tuscumbia, Ala.

Vicksburg, Miss.

Cincinnati, $O$.

Memphis, Tenn.

Rock Hill, s. O.

Wilkesbarre, Pa.

Newport News, Va.

Philadelphia.

Columibia, Mo.

Boston, Mass.

Danville, Ky.

Jacksonville.

Ardmore, Okla.

Beaumont, Tex.

Seattle, Wash.

Birmingham, Ala.

Washington, Ga.

Portland, Ore.

Albany, Ga.

Hampton, Va.

Spring field, Ill.

Cleveland, 0 .

New Orleans

Red Bank. N. J.

Memphis, Tenn.

Bilmingham, Ala.

Chicago

Topeka, Kan.

Sumter, S. C.

Portland, Ore.

Spring fleld, Ill.

Helena, Ark.

Staunton, Va.

Beaufort, S.C.

Boley, Okla.

Jacksonville

Huntsrille, Ala.

Atlanta, Ga.

Pueblo, Col.

Tuskegee, Ala.
Year Pp. L.M. Size

$1895 \quad 4 \quad 51 / 2 \quad 18 \times 24$

$\begin{array}{llll}1895 & 8 & 10 & 15 \times 29\end{array}$

$\begin{array}{llll}1895 & 4 & 5 & 15 \times 22\end{array}$

$\begin{array}{llll}1895 & 4 & 11 & 18 \times 24\end{array}$

$\begin{array}{llll}1895 & 4 & 181 / 2 & 20 \times 26\end{array}$

$\begin{array}{llll}1895 & 4 & 9 & 16 \times 29\end{array}$

$\begin{array}{rrrr}1896 & 8 & 15 & 13 \times 20 \\ 1896 & 4 & 1 & 15 \times 22\end{array}$

$\begin{array}{rrrr}1896 & 4 & 1 & 15 \times 22 \\ 1896 & 4 & 12 & 18 \times 24\end{array}$

$1896 \cdot 8-3 \quad 11 \times 16$

$\begin{array}{llll}1895 & 8 & 40 & 15 \times 29\end{array}$

$\begin{array}{llll}1890 & 8 & 40 & 15 \times 22 \\ 1896 & 8 & 10 & 15 \times 29\end{array}$

$\begin{array}{llll}1896 & 8 & 27 & 15 \times 22\end{array}$

$\begin{array}{llll}1897 & 9 & 221 / 2 & 13 \times 20\end{array}$

$\begin{array}{llll}1897 & 4 & 10 & 15 \times 9\end{array}$

$\begin{array}{llll}1897 & 4 & 131 / 2 & 18 \times 24\end{array}$

$\begin{array}{llll}1897 & 8 & 13 & 15 \times 19\end{array}$

$\begin{array}{llll}1897 & 4 & 10 & 13 \times 19\end{array}$

$\begin{array}{llll}1897 & 8 & 141 / 2 & 13 \times 20\end{array}$

$\begin{array}{llll}1897 & 4 & 41 \% & 18 \times 24\end{array}$

$\begin{array}{llll}1897 & 4 & 19^{-2} & 12 \times 19\end{array}$

$\begin{array}{llll}1807 & 8 & 161 / 2 & 15 \times 22\end{array}$

- $18 \times 24$

$\begin{array}{llll}1898 & 8 & 13 & 15 \times 22\end{array}$

$\begin{array}{llll}1898 & 8 & 13 & 12 \times 20\end{array}$

$\begin{array}{llll}1898 & 8 & 13 & 11 \times 16\end{array}$

$\begin{array}{llll}1898 & 8 & 15 & 15 \times 22\end{array}$

$\begin{array}{llll}1898 & 4 & 6 & 18 \times 24\end{array}$

$\begin{array}{llll}1898 & 8 & 14 & 9 \times 12\end{array}$

$\begin{array}{llll}1899 & 8 & 8 & 15 \times 22\end{array}$

$\begin{array}{llll}1899 & 4 & 141 / 2 & 15 \times 21\end{array}$

$\begin{array}{llll}1900 & 8 & 311 / 2 & 18 \times 22\end{array}$

$1900 \quad 4 \quad 15 \quad 15 \times 22$

$\begin{array}{llll}1900 & 4 & 71 / 2 & 18 \times 24\end{array}$

$\begin{array}{llll}1900 & 4 & 9 & 13 \times 21\end{array}$

$\begin{array}{llll}1900 & 8 & 10 & 13 \times 20\end{array}$

$\begin{array}{llll}1900 & 8 & 6 & 11 \times 15\end{array}$

$\begin{array}{llll}1900 & 4 & 6 & 18 \times 24\end{array}$

$\begin{array}{llll}1901 & 8 & 30 & 15 \times 24\end{array}$

$\begin{array}{llll}1901 & 12 & 12 & 17 \times 22\end{array}$

(?) $4 \quad 10 \quad 11 \times 17$

$\begin{array}{llll}1901 & 4 & 111 / 2 & 15 \times 22\end{array}$

- $15 \times 60$

$1901 \quad 4 \quad 92015 \times 22$

$1901 \quad 8 \quad 35 \quad 18 \times 24$

$\begin{array}{llll}1901 \quad 4 & 101 / 2 & 15 \times 22\end{array}$

$\begin{array}{llll}1901 & 8 & 12 & 18 \times 24\end{array}$

$19018811 \quad 13 \times 20$

$\begin{array}{llll}1902 & 4 & 41 / 2 & 16 \times 22\end{array}$

$1902 \quad 4 \quad 17^{2} 16 \times 22$

$\begin{array}{llll}1902 & 4 & 3 & 19 \times 18\end{array}$

$\begin{array}{llll}1902 & 4 & 6 & 13 \times 20\end{array}$

$\begin{array}{llll}1902 & 4 & 12 & 18 \times 24\end{array}$

$\begin{array}{llll}1902 & 8 & 8 & 13 \times 20\end{array}$

$\begin{array}{llll}1903 \quad 4 & 10 & 15 \times 22\end{array}$

$\begin{array}{llll}1903 & 8 & 7 & 12 \times 16\end{array}$

$\begin{array}{llll}1903 & 8 & 14 & 15 \times 22\end{array}$

$\begin{array}{llll}1903 & 4 & 81 / 2 & 18 \times 22\end{array}$

$\begin{array}{llll}1903 \quad 4 & 71 / 2 & 15 \times 22\end{array}$

$\begin{array}{llll}1908 & 4 & 7 & 15 \times 99\end{array}$

$\begin{array}{llll}1903 & 8 & 12 & 15 \times 22\end{array}$

$\begin{array}{llll}1003 & 4 & 7 & 18 \times 24\end{array}$

$\begin{array}{llll}1903 & 8 & 9 & 15 \times 22\end{array}$

$\begin{array}{llll}1903 & 8 & 9 & 15 \times 22\end{array}$

$\begin{array}{llll}1903 & 4 & 15 & 18 \times 24\end{array}$

$\begin{array}{llll}1904 & 8 & 11 & 15 \times 22\end{array}$

$\begin{array}{llll}1904 & 4 & 7 & 15 \times 22\end{array}$

$\begin{array}{llll}1904 & 4 & 8 & 11 \times 15\end{array}$

$\begin{array}{llll}1904 & 4 & 31 / 2 & 13 \times 20\end{array}$

$\begin{array}{llll}1904 & 4 & 8 & 15 \times 22\end{array}$

$\begin{array}{llll}1904 & 4 & 8 & 15 \times 22 \\ 1904 & 4 & 6 & 15 \times 22\end{array}$

$1904 \quad 4 \quad 11 \frac{1}{2} \quad 11 \times 16$

1904 6 $991 / 2 \times 121 / 2$

$1904 \quad 4 \quad 7$ 18x 24

$\begin{array}{llll}1905 & 4 & 10 & 11 \times 16\end{array}$ 
Name

American Problem

Nashville Globe

Light of the Race

Farmers' Courier

Southern Plowman

The Messen ger

Chicago Defender

Richomnd Planet

Mid-weekly Progress

Oolored Alabaniian

Waycross News

Wisconsin Weekly Defender

The Advance

Saturday Evening News

The Union

Union Messenger

Macon Dispateh

The Daily Metropolitan

San Antonio Inquirer

National Industrial Enterprise

The American Citizen

Kansas Oity Son

Yonkers Standard

Fessenden Academy Herald

New York Eye

Union Ledger

The Ligh

Mississippi Odd Fellow

Southern Indicator

The Advocate

The Plaindealer

Muskogee Oimeter

Conservative Counselor

The New Century

Spokane Oitizen

Atlantic Oity Weekly Topic

Washington American

Allen Student

Wagoner Lantern

Supreme Circle News

Bath Times

The New Age

The Sentinel

The College Journal

Baltimore Times

Appreciator Union

Negro Leader

St. John Herald

Baptist Herald

Ethiopian Phalanx

The Caret

The U. B. F. Searehlight

Fort Valley Uplift

New York Defender

The Forum

Wadesboro Enterprise

Indiana Register

Zanesrille Adrocate

National Aspect

Jackson Gazette

The Enterprlse

Illinois Chronicle

Pittsburgh Courier

A. M. E. Church Reriew A. M. E. Z. Quarterly Gazetteer and Guide

Business League Herald

The Horizon

MeGirt's Magazine

The Liberator

Negro World Echo

The Sixth Race Magazine
Published

Newport News, Va.

Nashrille, Tenn.

Newport News, Va.

Darlington, S. C.

Columbia, S.C.

Atlantic Oity, N.J.

Chicago, Ill.

Richmond, Va.

Memphis, Tenn.

Montgomery, Ala.

Waycross, Ga.

Milwaukee, Wis.

Providence, R. I.

Columbus, 0 .

Cincinnati, $\mathrm{O}$.

Dothan, Ala.

Macon, Ga.

Dallas, Tex.

San Antonio, Tex.

Washington, D. C.

Atlanta, Ga.

Kansas City, Mo

Yonkers, N. Y.

Fessenden, Ala.

Brooklyn, N. Y

Anniston, Ala.

Columbia, S. C

Holly Springs, Miss.

Spartanburg, S. C.

Boston, Mass.

Helena, Mont.

Muskogee, Okla.

Gonzales, Tex.

Norfolk, Va.

Spokane, Wash.

Atlantic City, N. J.

Washington, D.C.

Columbia, S. C.

Wagoner, Okla.

Albany, Ga.

Hot Springs and Cor-

ington, $\mathrm{Va}$

Los Angeles, Cal.

Richmond, $\mathrm{K} \mathbf{y}$.

Sarannah, Ga.

Baltimore, MId.

Ft. Smith.

Uniontown, Ala.

Montgomery, Aln.

Iynchburg, Va.

Corington. Ga.

Philadelphia.

Sedalia, Mo.

Ft. Valley, Ga.

New York

Spokane, Wash.

Wadesboro, N. O

Richmond, Ind.

Zanesville, 0 .

Chicago, IIl.

Jackson, 'Tenn.

Iuskogee, Okla.

Chicago, III.

Pittsburgh, $\mathrm{Pa}$

\section{Magazines}

Nashrille, Tenn.

Charlotte, N. O.

St. Paul, Detroit, Richmond, Va., and Montreal.

Washington, D. O.

Washington, D. C.

Philadelphia.

St. Louis.

Hot Springs, Ark.

Orlando, Fla.
Year Pp. L.M. Size

$\begin{array}{lccc}1905 & 4 & 41 / 2 & 15 \times 22 \\ 1905 & 8 & 27 & 13 \times 18 \\ 1905 & 4 & 15 & 15 \times 22 \\ 1905 & 4 & 41 / 2 & 15 \times 22 \\ 1905 & 4 & 221 / 2 & 15 \times 22 \\ 1905 & 4 & 8 & 15 \times 22 \\ 1905 & 4 & 14 & 18 \times 24 \\ 1905 & 8 & 12 & 18 \times 24 \\ 1905 & 4 & 6 & 15 \times 22 \\ 1906 & 4 & 10 & 11 \times 16 \\ 1906 & 4 & 3 & 15 \times 22 \\ 1906 & 4 & 51 / 2 & 15 \times 22 \\ 1906 & 4 & 71 / 2 & 15 \times 22 \\ 1906 & 4 & 14 & 11 \times 14 \\ 1906 & 8 & 6 & 15 \times 22 \\ 1906 & 4 & 8 & 15 \times 22 \\ 1906 & 8 & 8 & 15 \times 22 \\ 1906 & 4 & 9141 / 2 \times 101 / 2 \\ 1906 & 4 & 3 & 15 \times 22 \\ 1906 & 8 & 161 / 2 & 15 \times 22 \\ 1907 & 8 & 81 / 2 & 15 \times 20 \\ 1907 & 8 & 71 / 2 & 15 \times 22 \\ 1907 & 4 & 11 & 15 \times 22 \\ 1907 & 8 & 11 & 9 \times 12 \\ 1907 & 8 & 81 / 2 & 13 \times 20 \\ 1907 & 4 & 31 / 2 & 13 \times 20 \\ 1907 & 8 & 9 & 15 \times 22 \\ 1907 & 4 & 13 & 15 \times 22 \\ 1907 & 8 & 15 & 13 \times 22 \\ 1907 & 8 & 19 & 15 \times 22 \\ 1907 & 4 & 16 & 15 \times 22 \\ 1907 & 8 & 14 & 15 \times 22 \\ 1907 & 4 & 5 & 15 \times 22 \\ 1908 & 4 & 7 & 15 \times 22 \\ 1908 & 8 & 15 & 11 \times 16 \\ 1908 & 4 & 8 & 15 \times 22 \\ 1908 & 4 & 10 & 18 \times 24 \\ 1908 & 4 & 15 & 16 \times 22 \\ 1908 & 4 & 8 & 13 \times 20 \\ 1908 & 4 & 151 / 2 & 15 \times 22 \\ & & & \end{array}$

$1908 \quad 4 \quad 31 \% \quad 18 \times 24$

$\begin{array}{llll}1908 \quad 4 & 10 & 15 \times 22\end{array}$

$\begin{array}{llll}1908 & 6 & 15 & 11 \times 17\end{array}$

$\begin{array}{llll}1908 & 4 & 16 & 11 \times 17\end{array}$

$\begin{array}{llll}1909 & 8 & 14 & 15 \times 22\end{array}$

$\begin{array}{llll}1909 & 4 & 12 & 13 \times 20\end{array}$

$19094 \quad 61 / 281 / 2 \times 14$

$19094 \quad 9 \quad 81 / 2 \times 12$

$\begin{array}{llll}1909 & 8 & 10 & 13 \times 20\end{array}$

$\begin{array}{llll}1909 & 4 & 61 / 2 & 15 \times 22\end{array}$

$\begin{array}{llll}1909 & 4 & 8 & 15 \times 22\end{array}$

$\begin{array}{llll}1909 & 4 & 13 & 15 \times 22\end{array}$

$19094 \quad 51 / 2 \quad 91 / 2 \times 12$

$1909 \quad \overline{4} \quad \overline{11} \quad \overline{16 \times 22}$

$\begin{array}{llll}1909 & 4 & 11 & 16 \times 22 \\ 1909 & 4 & 10 & 18 \times 24\end{array}$

$\begin{array}{llll}1909 & 4 & 12 & 15 \times 22\end{array}$

$\begin{array}{llll}1009 & 8 & 8 & 15 \times 22\end{array}$

$\begin{array}{llll}1910 & 4 & 12 & 18 \times 24\end{array}$

$1910+8 \quad 15 \times 22$

$\begin{array}{llll}1910 & y & 121 / 2 & 18 \times 24\end{array}$

$1910 \quad 4-151 \% \quad 15 \times 24$

$\begin{array}{llll}1910 & 8 & 18 & 16 \times 22\end{array}$

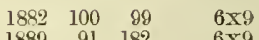

$\begin{array}{rrrr}1889 & 91 & 182 & 6 \times 9\end{array}$

$1900 \quad 24 \quad 91 / 2 \quad 11 \times 16$

$1908 \quad 12 \quad 34 \frac{1}{2} \quad 3 \times 12$

$\begin{array}{llll}1907 & 12 & 24 & 101 / 2 \times 8\end{array}$

(?) $40 \quad 60 \quad 6 \times 9$

(?) $96 \quad 145 \quad 71 / 2 \times 91 / 2$

$\begin{array}{llll}1910 & 64 & 36 & 63 / 4 \times 10\end{array}$

$\begin{array}{llll}1910 & 20 & 19 & 6 \times 83 / 4\end{array}$ 


\section{Papers Not Received, but Reported as Being Published}

The Tribune, Bessemer, Ala.

The Selma News, Selma, Ala.

Voice of the 20th Century, Argenta, Ark.

Union Trumpet, Montrose, Ark.

Reporter, Little Rock, Ark.

Fraternal Unlon, Fort Smith, Ark.

Echo, Hot Springs, Ark.

Eagle, Los Angeles, Cal.

The Forum, San Jose, Oal.

The Light, Colorado Springs, Oolo.

Delaware Advocate, Wilmington, Del.

Afro-American Ledger, Wilmington, Del.

Masonic Forum, Jacksonville, Fla.

Florlda Tribune, Marianna, Fla.

Ohristian Recorder, Orlando, Fla.

Advocate, Covington, Ga.

Baptist Truth, Macon, Ga.

Enterprise, Pulaski, Ga.

Standard World, Columbus, O.

Ohio Standard, Xenia, O.

Republican, Muskogee, Okla.

Sun, Ardmore, Okla.

The Western Age, Langston, Okla.

The Gazette, Buxton, Ia

The Enterprise, Salina, Kan.

The Searchlight, Wichita, Kan.

American Baptist, Louisville, Ky

Blue Grass Bugle, Frankfort, Ky.

Reporter, Mt.Sterling, Ky.

The Watchman, Shreveport, La.

Republican Llberator, New Orleans, La.

Louisiana Searchlight, Shreveport, La.

The Guide, Evansville, Ind.

The Sun, Oolumbia, S. O.

The Monitor, Green rille, s. C.

The Blade, Chattanooga, Tenn.

The Conservator, Memphis, Tenn.

The Signal, Memphls, Tenn.

The Paul Quin Weekly, Waco, Tex.
The Wlley Reporter, Marshall, Tex.

The Witness, Houston, Tex.

The Watchman, Austin, Tex.

Texas Pythian journal, Waco, Tex.

The Searehlight, Austin, Tex.

The Now Idea, Galveston, Tex.

The Item, Fort Worth, Tex.

The Loulslana Record, New Orleans, La.

The Advocate, Baltlmore, $\mathrm{Md}$.

The Appeal, Meridian, Mlss.

The Baptlst Reporter, Jackson, Mlss.

The Herald, Natehez, Miss.

The News Journal, Laurel, Miss.

Delta Light House. Greenville, Miss.

The National Mirror, Kansas City, Mo.

The Western Ohristian Recorder, Kansas Olty, Mo.

The Sentinel, East St. Louis, Ill.

The Slgnal, Kansas Uity, Mo.

The Palladium, St. Louis, Mo.

The American ditizen, Kansas City, Mo.

The Advance, St. Louis, Mo.

The Appeal, Jersey City, N.J.

The Industrial Watchman, Paterson, N.J.

Voice of Mlsslons, New York.

The Statesman, New York.

The National Review, New York.

The Gazette, Charlotte, N. O.

The Pledmont Advocate, Salisburg, N.C

The True Reformer, Littleton, N. C.

The Bee, San Antonio, Tex.

The Utah Plaindealer, Salt Lake City, U.

The National Pilot, Petersburg, Va.

The Virginia Baptist, Rlchmond, Va.

The Colored Union, Olifton Forge, Va.

The Westerner, Spokane, Wash.

Fair Play, Parkersburg, W. Va.

The Wisconsin Advocate, Milwaukee, Wis.

Section 18. Libraries. Most of the public libraries of the South exclude Negroes, even though they pay taxes; for instance, in Atlanta there is a Carnegie public library and a branch library supported by public taxation, to which Negroes have no access. This and the natural desire for books have led to movements for Negro libraries.

In Montgomery, Ala., the Sojourner Truth Club was organized about twelve years ago by a number of young women.

It has always stood for personal improvement and for social service. It meets twice a month, having one meeting devoted to business and the other to a literary program. For a number of years its benevolences were of a general character. For the past five years the strength of the club has been given mainly to the maintenance of a Free Reading-Room and Library. The establishment of the Reading-Room grew out of the fact that our people here were refused admission to the Carnegie Library. Appeals were made, in the churches and to the citizens in general, and about three hundred dollars collected to be used for furnishings. The present rooms were rented and the doors thrown open. At first the public was invited simply to come and read; later, as books were accumulated, books were loaned for use in the home. The expense of maintaining this work is between twenty and twentyfive dollars a month. It would be more, but the rooms are open for six hours 
daily instead of all day. There are about five hundred volumes of good literature.

The Sojourner Truth Club also gives an annual prize for the best paper written by a student of our Junior or Senior class on a subject connected with the history of the development of the race.

Our money is raised by entertainments and contributions. In having entertainments to raise money for even so laudable an undertaking as the Reading-Room and Library, we are scrupulous as to the character of these entertainments. We seek to have them at all times uplifting and elevating. Many of the most distinguished persons of the race have come to Montgomery under the auspices of this club. Among them are Prof. Kelly Miller, Dr. W. E. B. DuBois, Mrs. Mary Church Terrell, Dr. Booker T. Washington, Mr. Joseph Douglass, Mr. Clarence White and Madame Anita Patti Brown of Chicago.

Only thirty women compose this faithful little band. They have always stood for the highest and best things in club life, and have never shirked duties because they were hard.

From Guthrie, Okla., we learn:

The colored people of Guthrie have an organization known as the Excelsior Club, which is conducting a library for the Negroes. The city has appropriated a part of the taxes for its maintenance, but since it is conducted wholly and partially supported by Negroes, it ought to be counted. It is called the Excelsior Club Library.

There is also a colored library in Dallas, Tex., and one has just been incorporated in Jacksonville, Fla.; besides this, Jacksonville has a colored department to her public library.

The number of books loaned from the colored department has increased from 5,031 in 1907 to 7,182 in 1908, an increase of 2,151. The registration has nearly doubled, beirg 121 in 1907 and 234 in 1908. Even with this increase, howerer, the use of the department is still very small when the large colored population of the city is considered. If the time should come when a separate branch library for the colored people could be conducted, we are convinced that the registration and circulation could quickly be very greatly increased. For the present, howerer, the finances of the library forbid this important step. In Norember the librarian gave an address at the Florida Baptist Academy, a colored school, on the subject "What Books are For."

The Colored Branch of the Louisville, Ky., public library says:

In outlining the library system for Louisville the Trustees wisely planned a special library for the 40,000 colored eitizens. After the opening of the main library the Colored Branch came next on September 23, 1905, in temporary quarters. At the same time the Board purchased a site at Tenth and Chestnut streets, where one of the Carnegie branch buildings was erected, and opened October 29, 1908 .

The new building is 77 feet long and 45 feet wide, two stories high, built of brick with some trimmings and tile roof. On the main floor near the entrance is the delivery desk and back of it are large tables with abundant space for reading and reference; to the left on entering is a newspaper alcove, an office and the special children's room; to the right is a magazine alcove, a special room for adults and a small study-room. The ground floor contains a large lecture-room, two class-rooms, and supply and boiler rooms. 


\section{Day Nurseries}

COST OF PLANT

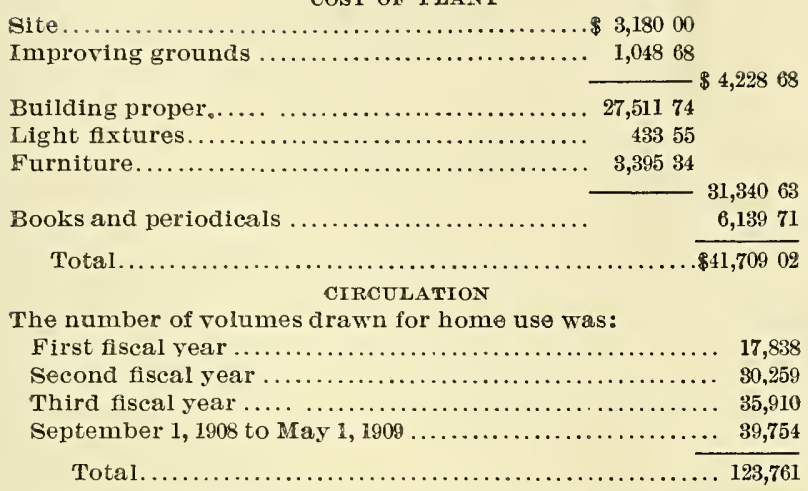

The library contains 6,882 volumes of books and 65 current magazines and periodicals, all of which are free. New books are being added constantly. The branch serves as a reference library for the colored schools. Books are distributed free, not only at the branch proper but also at various public schools.

The opening of its doors marked an epoch in the development of the race. It is the only institution of its kind in existence and has been a success from the beginning. Since its opening 123,761 volumes have been drawn for home use; of these only 38 per cent were fiction and 67 per cent were children's books. It is at present in such high favor that the Library Trustees in May 1909 voted to establish a Second Colored Branch in the eastern portion of the city.

Besides these Hampton Institute sends out Traveling Libraries, and the number sent from Atlanta University has been increased this year to twenty-five.

Section 19. Day Nurseries. We now come to a set of specialized and more scientific charities, and many of which the Negro population as a whole is just learning. There are, therefore, comparatively few examples of these among them, but the few that are arising are very significant.

The Day Nursery is a widespread and crying need among Negroes. There ought to be not only several in each city and town, but also in country districts. It is a potent field for philanthropic enterprise.

The Women's Union Day Nursery in Philadelphia is one of the most successful.

The Women's Union Day Nursery was first opened November, 1898, at 1508 Lombard street, and so is now in its tenth year. It is entirely conducted by an organization of colored women of every religious denomination. Its support has come almost entirely from our own people. The children of parents whose work calls them from home are taken care of from 6.30 a.m. to $6.30 \mathrm{p.m}$. for five (5) cents a day. They receive excellent care, and three wholesome meals are provided. All children of the proper age are sent to the kindergarten or school. 
The Nursery is now located at $707 \mathrm{~S}$. 19th street, this property having been recently secured by the Women's Union Missionary Society as a permanent home. Since moving into the new location, May 10th, an aggregate number of three thousand four hundred children have been cared for. The largest attendance in one day was forty.

This increase in work has made a corresponding increase in expenses, and we strongly appeal to all, particularly the church, to help to carry on this most excellent charity.

The society that carries this on has a membership of 200 and has spent about $\$ 2,000$ annually. The property at $707 \mathrm{~S}$. 19 th street cost $\$ 4,000$, and $\$ 1,000$ worth of repairs put upon it. The work is purely charitable and no one in the organization receives any remuneration.

The Day Nursery in Columbus, O., on the other hand, was begun and is still supported largely by white people.

This institution was inaugurated by the Woman's Educational and Industrial Union, a corporation of Christian women (white) of this city, February 4 th, 1901, in a two-story fire-room frame building, at $231 \mathrm{~N}$. Ohio avenue.

At the opening of the Nursery a matron and cook were employed and three children constituted their first care, which number has gradually increased until at the present time they number 58 .

Realizing the necessity of some assistance from the colored people in carrying on this work, on April 19th, 1901, an auxiliary board of managers was organized among them, consisting of four members, who worked in conjunction with the white board.

Owing to the rapid growth of the institution the auxiliary board was, in 1902, increased to twelve members.

About this time it became apparent that this building was not adequate for the growth of the Nursery. As the necessity for more room and increased facilities for doing the work became evident, it was decided by the board to purchase larger quarters, which they did by securing the present quarters, a seven-room brick house, modern, with two large lots at $162 \mathrm{~N}$. Ohio avenue, in the name of The Woman's Educational and Industrial Union.

In Lexington, Ky., there is a Day Nursery just beginning:

The Woman's Improvement Club has purchased a four-room cottage with nice playground, in which to begin this work. The house is now undergoing repairs, and I was so successful as to solicit the material necessary for said repairs. Lumber, paint, paper, roofing and guttering have been given. The workmen readily responded to the request to give a portion of their labor. As soon as the house is ready for use we have the promise of furniture.

The Nursery in Washington, D. C., at $69 \mathrm{O}$ street, is supported almost entirely by white people.

The Nursery at Pittsburgh, Pa., reports:

Some ladies of the Baptist church have established a Day Nursery at 3211 Penn arenue, which is filling a long-felt want. They also take children temporarily, which lias been a great help to the Jurenile Court work.

The Douglass Club of Austin, Tex., is seeking to establish a nursery and there are other nurseries established on Rodman street, Philadelphia, and Bainbridge street, in the Lincoln Settlement of Brooklyn. N. Y., in Richmond, Va., Athens, Ga., Louisville, Ky., and Los Angeles, Cal. There are probably a number of others unreported. 


\section{Social Settlements}

Section 20. Social Settlements. There are a few Social settlements among the Negro city populations, and considerable unorganized slum work like that of the Women's Twentieth Century League in Mobile, Ala.

The Presbyterian Colored Missions maintained by the Southern white Presbyterians of Louisville, Ky., is a specimen of settlement work. They report as follows:

The Presbyterian Colored Missions celebrated the tenth anniversary of their organization on April 14, 1907, and the work has now passed the experimental stage and is a firmly established factor for good in this community. The year which closed on March 31, 1907, was one of marked progress and some permanent results were achieved. There were more pupils enrolled, more religious services conducted, and more industrial classes instructed each week, than ever before in their history.

The average weekly attendance for the year was as follows:

\begin{tabular}{llc} 
& \multicolumn{3}{c}{ Pupils } & Teachers \\
First quarter, April-June, $1906 \ldots \ldots \ldots$ & 445 & 52 \\
Second quarter, July-Sept., 1906........ & 427 & 25 \\
Third quarter, Oct.-Dec., 1906......... & 539 & 47 \\
Fourth quarter, Jan.-Mch., 1907...... & 677 & 54
\end{tabular}

The average weekly attendance for first three weeks in April, 1907, showed 744 pupils and 54 teachers.

They maintain a cooking-school, carpentry shop, sewing-school and public playgrounds. This work is supported almost entirely by Southern whites.

On San Juan Hill, New York city, a noted Negro quarter, is a missionary settlement work supported by the white Episcopalians and carried on by colored priests and workers, known as St. Cyprian's Chapel. This settlement ministers to over 1,500 families, and has a new parish house and four workers.

The new building has made it possible to assemble our congregation under healthier and more churchly conditions, and so our services have continued to grow, not only in numbers but in heartiness and reverence. With our new gymnasium, our shower baths and lockers, we have been enabled to carry out our long-cherished desire to enlarge the scope of our work among our boys and girls as well as that with young men and women of the neighborhood. For six afternoons and evenings of each week, under safe and competent instruction, our young folks are carried through exercises that will tend to give them strong and vigorous bodies. In this connection I ought to mention also the excellent work done by four young women, communicants of St. Cyprian's, as visitors, nurses, or model home-keepers in our district.

Several doctors, white and colored, meet the mothers in our rooms, and after examining the infants give talks as to their proper feeding and clothing. The New York Milk Committee has kindly supplied pure milk to such as were too poor to buy it. Some 200 children have been handled. Of this number not six died during the summer.

Four hundred and twenty girls are enrolled in cooking and sewing-schools. The cooking-school has grown into a lunchroom where poor and hungry school children and other sick folk are fed.

During the month of October 156 meals were given to the poor, while the 400 sold to school children about covered the total expenses. Once a month 
our young people have donation parties, at which time they bring gifts of groceries, canned goods and regetables for the lunchroom. In the sewing-school our girls continue to make underwear and dresses which wher finished are given or sold to them. Out of the sewing-school bas come an industrial exchange which gives sewing to worthy women who come to us seeking employment. The garments made by these workers are sold through our Clothing Bureau, as are second-hand shoes and other clothing. We repair our shoes through our cobbling classes.

Chicago furnishes a settlement of a different type-the Frederick Douglass Center, on Wabash avenue. This work was founded by Celia Parker Woolley, and its object is stated to be: to promote a just and amicable relation between the white aud colored people; to remove the disabilities of which the latter suffer in their eivil, political and industrial life; to encourage equality irrespective of race, color, or other arbitrary distinction; to establish a settlement of friendly helpfulness and influence in which to gather useful information, and for mutual co-operation for the needs of right living and higher citizenship. One of the reports says:

The Frederick Douglass Center is increasingly busy on old and new lines. Its work is educational and philanthropic.

The Negro in this country suffers not only those hindrances that spring from his former enslavement, but he suffers even more from the obstacles imposed in race and caste feeling. Our treatment of the colored people in this country constitutes the greatest charge that can be made against our patriotism, our religion, our humanity. The civilized world stands aghast at the crimes committed almost daily by race hatred in this country, the most adranced cirilization under the sun.

The darkest spot on our national escutcheon is race prejudice. This feeling exists in other parts of the rorld: in Russia against the Jew, in Great Britain against her Irish, Boer and East Indian subjects, but nowhere does this feeling find more brutal expression than with us. Nowhere is it a greater travesty on the general creed and profession than in our free republic.

This attempt to establish a center of friendly influence and co-operation between the races has inet the approval of representative men and women of highest standing ou both sides the color line. Its demand for the colored people is equal opportunity. Its plea to the white is for simple justice, while its labors for the moral uplift of the people in its vicinity are incessant.

The workers are both colored and white, and the activities consist of a woman's club, sewing-class, children's singing-class, study-class, an orchestra, quartette and religious services Sunday afternoon; besides this there are social meetings of colored and white people with lectures and talks. A building worth $\$ 5,500$ has been bought, and no salaries are paid except to the sewing teacher, the janitor and the housekeeper.

One of the best social settlements along regular lines is the Colored Social Settlement on M street, Wrashington, D. C. It is conducted by colored and white people and is doing an excellent work.

In the rear $1902 \mathrm{Mr}$. Charles F. Weller, former secretary of the Associated Charities of this city, founded in southwest Washington a colored social settlement. The object of this organization was to place before the neglected and unfortunate colored people such principles of industry and right living as 
would remove the causes of dependence which exists so prominently among a great number of the people in southwest Washington.

In two small meanly-provided houses situated at 116-118 M street S.W., this institution has been located since it was founded. These houses are without even water. Besides visiting the neglected homes of the unfortunate colored people of this district, teaching them morality, temperance, religion, and neatness in domestic life, this settlement maintains a day nursery where the babies of working mothers are cared for through the day, while the mother provides for house-rent and other necessities of life. We are also giving instructions in housekeeping, cooking, sewing and drawing. Again, the settlement has managed a stamp savings bank where, in the year of 1908, over a thousand dollars, mostly in pennies, were deposited by children and adults who had probably never saved a cent before: now they were learning their first lesson in thrift.

The public can little imagine the immense good this work has done for the colored people of southwest Washington, and little can they imagine the great work that yet remains to be done. The problem is a difficult one, but if the generous-hearted and Christian people of this city support us, in time the desired work will be accomplished.

At present there is under erection a sixteen room building which will better accommodate the work. And there will be carried on in this building in addition to the industries taught at the present Settlement House, carpentry, shoe-repairing and chair-caning. A library and gymnasium will also be provided. The cost of this building is $\$ 6,000, \$ 1,000$ of which will go for the equipment. There must also be raised $\$ 200$ per month for the running expenses.

As this institution is supported entirely by voluntary contributions, we must look to the public for the money with which to pay this debt and at the same time keep the work in progress.

Philadelphia has three colored settlements. The Eighth Ward Social Settlement has three residents and 22 workers.

The Starr Center, an old work, has a branch of the city library and a coal club of a thousand members who pay in over three thousand dollars a year; medical visitation, a dispensary, kindergarten, penny lunches and a savings bank. This is supported very largely by white people and most of the workers are white.

The Spring Street Settlement has both colored and white managers and workers. It has the following departments of worls:

Gymnasium class for large boys, in which wholesome talks are given.

Cobbler class. To teach older boys to mend and to make shoes.

Chair-caning class. To teach younger boys to cane chairs.

Dressmaking class. For older girls.

Domestic science class. To teach girls plain house-keeping duties.

Social evenings for small boys and girls. Some preliminary work is done, after which games are played, lantern talks given, etc.

Social evenings for large girls. Same as above.

Mothers' meetings. To discuss helpful topies of home-life and care and training of children.

Savings fund.

Library.

Fuel savings fund.

First-day (Sunday) school.

Colored probation officer. 
Visiting nurse. Colored trained nurse who calls on families when illness is reported and sees that medical attendance, medicines and proper diet are obtainable; also that cleanliness, ventilation, etc., are observed. Visits and assists daily or when necessary.

The Lincoln Settlement is in Brooklyn, N. Y. It has a kindergarten, day nursery, visiting-nurse, and physician. It is supported by white and colored people-the president, Miss Mary W. Ovington, being white and the head worker being colored.

The eleventh ward of Brooklyn for nearly a century has been the home of colored people, and it remains so to-day despite the encroachment of business houses. Fleet, Prince, Nars and Fair streets and Hudson avenue are largely populated by the Negro race.

Poverty dwarfs the life of this ward, and vice and crime thrive on some of its streets. Myrtle avenue has a crowd of loafers who corrupt its neighboring boys, and a decent girl avoids Hudson avenue at night. Disease breeds in the rear tenements and in the frame houses, too dilapidated to be worth repairing. Sometimes the nights are noisy with carousing, and the worthy families whom necessity forces to live with the bad, see their children in contact with much that they can not remedy but deeply deplore.

In this neigh borhood, at 105 Fleet place, the Lincoln Settlement was opened in May, 1908. Its organizers hope that it will stand for a center of social service to the neighborhood, and especially to the colored people who are not reached by other philanthropic organizations.

The Flanner Guild, of Indianapolis, Ind., is a neighborhood home established about ten years ago. The properties were given to the Negroes of Indianapolis by a prominent white undertaker, Frank. W. Flanner. The first property given had on it a double house of four rooms, two on a side, which was repaired, furnished and made comfortable for the work and used for two rears. The work grew so rapidly that it was necessary to have a larger building. Mr. Flanner then gave another piece of property and the building now occupied was erected. It has an office, reading-room, a large convenient kitchen, an assembly-hall with a seating capacity of two hundred; joining this building is a four-room residence.

The Guild is a charitable institution for the moral and industrial uplift of the Negro boys and girls, and is struggling and striving to do its duty in the neighborhood. In the office we have a telephone for the accommodation of the public; an employment ageney is managed by the matron. The readingroom has games and literature for the children and they spend their idle hours here, and each evening from seven to nine o'clock the room is crowded.

We have a boys' club with a membership of thirty-five. On Wednesday evening of each week these boys are instructed in military drilling by Captain James Anderson.

The kitchen is large and properly equipped for the instruction of cooking classes, or the preparations of serving clubs, receptions and social gatherings.

The assembly is bright and cheerful, with a large platform aud a piano. On Sunday afternoons during the winter months we have one hour's devotional service and a short program, which are usually well attended, owing to the fact that some of the best talent participate from time to time. We know that great good has been accomplished in the neighborhood. Clubs and 


\section{Social Settlements}

literary societies have the privilege of using the hall at any time, and our entertainments and social gatherings are held with great satisfaction.

We have an orchestra of nine pieces under the direction and management of Mr. Smith, with Ruth E. Guthrie, aged fifteen years, as pianist. They rehearse Tuesday and Friday evenings of each week.

Sewing and millinery are taught the girls by the matron and the voluntary service of women interested in the success of the work.

The day nursery for the little tots adds much to the work; ten cents each per day furnishes lunch for them. Many mothers are compelled to work aw ay from home, and the larger children are in school; but their minds can be at ease, for they know that their little tots are kept warm, have something to eat and are out of danger of the evils of the city.

We have a choral society with an enrollment of seventy-five, under the direction of Professor Robert Anston. This gives those musically inclined a chance to learn all the rudiments of music and voice culture.

After the present matron had been in the work about a year it was deemed necessary to open another branch of work that we might have a place to care for fallen Negro girls; there being no place in the city among the white institutions that would accommodate them. March 1, 1908, the first cottage mentioned was comfortably fitted and furnished for a maternity home. This has a sitting-room, dining-room, dormitory and kitchen. Friendless fallen girls ranging in age from 15 to 21 year's are placed in this cottage, nursed and cared for until they are able to return to work.

Medical assistance is donated by the different physicians of the city. Drs. A. J. King and A. H. Wilson were the first to serve us. We also accept young girls with their little ones from the city hospital, as they are discharged in two weeks after their illness regardless of where they are to go. We encourage the girls to keep their babies, and do everything in our power to find homes for the girls and their little ones. We endeavor to surround these girls with Christian and motherly influence, with kindness and sympathy to make them feel they have friends, and though they have sinned they can be forgiven and may improve their lives by being honest Christian girls. Ten girls have been nursed in the Home and ten from the city hospital with babies have been cared for.

This work is wholly dependent upon the generosity of the public for maintenance, and so far we have been able to successfully carry it on. There is a Ladies' Board of Managers who work earnestly to help us.

A nine-room house and lot was given the Guild by Rev. Moses Dixon. This property was not convenient for the work here, it being in another locality. The board of trustees decided it best to sell this property and pay off the indebtedness of the Guild. This was done and the Guild proper is free from debt.

The county appropriates $\$ 500$ each year, which is used for current expenses.

Much and lasting good has been accomplished since the establishment of this institution in this neighborhood; as the time goes on the results become more evident.

Some of the colored schools are doing settlement work. The Institutional Church of Atlanta, for instance, with its various settlement activities, has a membership composed largely of Atlanta University graduates. Atlanta Baptist College supports a Neighborhood Guild. There is a large Baptist church doing institutional work in Jacksonville, Fla. There are two settlements at Hampton, Va. 
The two settlements in which the school takes an active part are located in the town of Hampton and in the country near-by. Both are in charge of resident workers who are not directly connected with the school. The former is the larger. It has a clubhouse and makes use of the home and grounds of Mrs. Harris Barrett, who founded and still carries on the work. Six girls' and women's clubs meet here-five every week and one every month. The membership is from one hundred twenty-five to one hundred fifty. They meet "to learn sewing, to do quilting, to talk about the care of the home, to cultivate the love for flowers, and to do other useful things which make for a better and happier life." Four boys' clubs with a membership of about sixty-five and a night-school with an average attendance of twelve also use the Barrett home regularly. The object of the club is to create a desire for healthful pleasures, such as singing, reading, table and athletic games. One club has a bank account of thirty dollars.

In some cases the associated charities have colored auxiliaries or workers who are doing systematic charitable work; in Harrisburg, Pa., for instance, there is a ladies' auxiliary to the Associated Charities, with 54 members and a bank account. They think of opening a social settlement.

At Columbus, O., the Associated Charities reported in 1909:

For several years past a full third of all our families have been colored families. Believing that a properly-qualified visiting agent of their own race would be more helpful in tracing out the causes of their distress and stimulating them to self-help, we secured last fall the services of Miss Bowles, whose work this past year has proven the truth of our contention beyond a doubt. We feel that this is one of the most important advances we have made during the year.

Section 21. Kindergartens. The most elaborate effort at systematic free kindergartens is that of the Gate City Free Kindergarten Association of Atlanta, Ga. Some years ago some colored people of the city started a free kindergarten association. It ran a kindergarten for two years and then getting into financial difficulties suspended. Later, at one of the Atlanta University Conferences, Miss Gertrude Ware, the white superintendent of kindergarten methods in the Atlanta University Training School, suggested a new beginning of the work. The colored women rallied again, and the result has been five free kindergartens here in operation; four of them since 1905 and the fifth started last year. The following are the figures concerning these kindergartens:

\begin{tabular}{|c|c|c|}
\hline & Raised & Expended \\
\hline $1905-06$ & $\$ 1,04360$ & $\$ 44319$ \\
\hline $1906-07$. & 68963 & 95000 \\
\hline 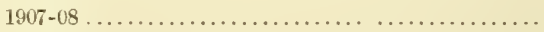 & 54605 & 92115 \\
\hline 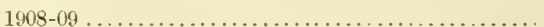 & $1,089 \times 6$ & 1,01100 \\
\hline
\end{tabular}

Average attendance each kindergarten, 25 in a.m., and 15 in p.m. Total arerage attendance .................... 200 children. At such times as Christmas 400 children are reached.

No aid is received from the State, although the white kindergartens receive such help. 
In Columbus, Ga., on the other hand, the colored association began and supported the kindergartens, but they were eventually taken over by the city.

In Gainesville, Tex., the Women's Reading Club is about to establish a free kindergarten.

Many of the settlements, like the Lincoln Settlement, Brooklyn, the Star Centre, Philadelphia, and the Washington Settlement, have kindergartens connected with them.

In Anderson, S. C., the only club or institution doing wholly charitable work is the Thurman Kindergarten Club which has established and maintained a free kindergarten for the past seven months, paying a teacher forty dollars per month and purchasing material and furniture. The president of this club is also president of the W. C. T. U., of which the kindergarten club is an auxiliary.

The colored women of Harrisburg, Pa., are planning to establish a kindergarten and a day nursery.

It will thus be seen that the kindergarten idea is new and being developed only in a few center's.

Section 22. Civic Reform. The continued charges of criminality against the Negroes have aroused sentiment among them ill many places. These charges are known to be exaggerated and unjust, but, at the same time, it is recognized that by reason of economic transition and racial prejudice it is much easier for colored boys and girls to fall into crime than for most white children. Effort, therefore, is being put forth here and there to reclaim criminals, stop erime, and spread some knowledge of civic duties. These efforts, however, are dependent for their successes very largely upon the attitude of the authorities. In the Snuth, and especially the lower South, the colored people are almost helpless; they have few or no representatives on the police force; no influence in the police courts; no control over the jail and methods of punishment. Personal influence mav do something, but, for the most part, they have to sit by and see children punished unintelligently and men and women unjustly. In the Border States and in some of the large cities of the North, however, constructive work is being done. In Johnstown, Pa., for instance:

We have a probation officer in the person of your humble servant, appointed by a Democrat judge of this county. I am a member of the Civic Club (white) and was recommended by the said club. We have several white probation officer's and they wanted someone to look after the dependent cololed children. All children sent by the Cambia Civic Club to the various schools, our .county pays $\$ 1.50$ for their board.

Pittsburgh, Pa., reports:

Our Juvenile Court Association was formed about three years ago to help care for the colored Juvenile Court children who were without friends. Heretofore we have been paying for some boys and girls in different institutions and have found private homes for many others. We have now decided to pay the salary of a probation officer instead of paying board for children in 
institutions, thinking that we can the better serve our race thereby. In Pittsburgh the county does not pay the salaries of probation officers, but they are paid by private organizations, clubs, etc. The Juvenile Court Association (white) pay five; the Catholics pay two; the Jews pay one, and the Colored Association pays one. The legislature now sitting in Harrisburg may pass a bill providing for the payment of the salaries and this association will provide only for the charitable end of the cases, for there is much destitution attending many cases.

Kansas City, Missouri, has the Negro Civic: League, an organization composed of about forty of the leading colored men, ministers, teachers, business men, etc., devoted to the social, moral, physical, political, economic and intellectual betterment of the race. A part of the work of this civic league is extremely interesting. It has taken over a suborganization called the "Brotherhood."

The society was formed at the request of the Board of Pardons and Paroles, with which it works as a committee on Negro cases. This Board. at the outset of its work, found it impossible to deal justly and intelligently with Negroes brought before them, because of a lack of information concerning their cases. Hence, a few of our prominent public-spirited citizens were called in and formed into a committee, whose duty should be to examine and report upon all Negro cases before action by the Board. Our committee felt a great responsibility resting upon its shoulders, in fact we feel now that we are on trial, as our attitude toward each case is scrutinized carefully, and never before has such an opportunity been given to us to protect and encourage our unfortunate masses.

To systematize and make our work efficient, the committee divided the city into fifteen districts, each having from one to five workers-members of the Brotherhood-all of whom were selected with special attention to their moral worth in the communities in which they reside. The duty of these members is to keep in close touch with the life of their districts and report upon all cases of crimes and misdemeanors or any irregularity to our executive committee of seren-fire men and two women-who after due deliberation forwards its result to the Board.

The work of the Brotherhood does not end there: Each person paroled must report weekly to onr secretary and tell us what he is doing, and we are to encourage him by visits and advice, keeping always in touch with him.

Up to this writing we have secured some fifteen pardons, none of whom has broken his faith with the Board. But even more, we have been able to prevent many petty cases from going on record by using our influence for a good, healthy moral tone in our districts. Disorderly houses, illicit practices and many other offenses have been checked by bringing quiet but forceful pressure to bear upon them.

There are no salaried positions and no money is solicited or required by us whatever. Each worker feels that the opportunity to do something for our more unfortunate brethren, and the opportunity of coming in contact with the best element of the white men and women of our city, is ample reward for our services.

In Baltimore the Colored Law and Order League has been waging a fight against disreputable saloons, with considerable success. ${ }^{1}$

1 cf. Waring: Work of the Colored Law and Order League, Baltimore, Md. Oheney, Pa., 1910. 


\section{Civic Reform}

Springfield, Ill., has a Law and Order League formed since the disgraceful race riot.

In various Southern States there have been efforts to establish reformatories. In Richmond, Va., a colored man, the Hon. John R. Smythe, formed a Negro Reformatory Association.

He secured subscriptions and laid his plans before the Prison Association of Virginia and received their endorsement. He then organized and incorporated the Negro Reformatory Association of Virginia, of which he was president until his death. With the money obtained by his efforts from philanthropists, north and south, the association purchased 405 acres of the old plantation known as Broad Neck Farm. The remaining 1,200 acres was later purchased by Mr. C. P. Huntington and leased to my father for the use of the school.

In 1898 the school was started with six boys from the penitentiary pardoned by the Governor, and committed to the institution for the remainder of their terms. The State then made an appropriation for the support of 100 boys at 83 cents per day for clothing and 25 cents per day for board. Out of this annual income, together with subscriptions, my father was able to clear up the land, build dormitories, start farming operations on a large scale, and pay all the employees, about 14 in number.

The work of the school has been excellent from a moral standpoint. The percentage of lapses into former errors have been, I believe, less than ten per cęnt. These lapses have been mostly among the older boys. The work carried on at the Reformatory is mostly agricultural. It was my father's hope to ultimately establish a first-class trades school, but as yet it has been impossible to start this school with the limited means at the command of the institution.

In Alabama, as has been noted, the State Federation of Women's Clubs opened a Negro Reformatory at Mt. Meigs, and has been supporting it, hoping for eventual State aid.

In Arkansas the Women's Clubs have done a similar piece of work.

In Georgia there have been several small reformatories started. One in Macon reports:

We are styled the Delaney Mission and Reformatory Club. We were organized February 19, 1906, with five members, and have now an enrollment of over sixty. The Reformatory which we help to support is situated three miles from the city of Macon. It is an institution for wayward boys and girls. The school is not a denominational school, but its founders and ehief supporters are Baptist ministers and the laymen of their churches. We meet once a week and put our little mites together, and by that means we have been able since we were organized to raise in actual cash $\$ 375$ for the Reformatory, part of which we gave to the Convention to be used for erecting a large building at the Home and with the other we bought a buggy for them and a cow and paid for both. We have given them aid aside from the things mentioned above, by way of clothing and food, giving picnics, etc.

The Johnson's Orphanage of Macon, Ga., and the Carrie Steele Orphanage of Atlanta, Ga., are partially reformatory; the latter is aided by the City of Atlanta.

The National Association of Colored Women's Clubs has been interested in juvenile work in various parts of the country. 
The Unity Political Club of Haverhill, Mass., aims

"to encourage political, economic and educational activity among colored citizens of Essex county." This club has only been organized nine months. It is pledged to no one party, but is simply pledged to the good of the city and State and race.

In Paducah, Ky., there was a movement in this line:

The Forum movement was begun in our town, but everything is dormant at present. I was connected with a similar movement in Bowling Green, Ky. The Forum there had an interesting career of four or five years, bringing the colored people together monthly for the discussion of vital matters incident to our race life, working up a spirit of racial co-operation, and culminating in the opening of a grocery which did a creditable business. I should mention also that through the agency of the Forum the city council abolished certain nuisances repugnant to the better element of our people.

While I have been active in the above mentioned organizations, yet the idea came to us (as well as I can remember) from Chicago and Kansas City, Kan.

The following extract from a set of resolıtions show the purpose of the Organization:

"Further be it resolved, that we organize ourselves into a body to be styled "The Forum," which shall meet monthly, on a Sunday afternoon convenient to the coming together of all the congregations of our city churches, and whose object shall be to take constant note of the conditions and needs of our people; to allow opportunity for free and open discussion of these conditions and needs; and to take such steps and measures, and to initiiate such enterprises and movements, as will promote the religious, moral, educational, civic and temporal welfare of our people."

In Lynchburg, Va., there is a Civic League, and also one in Washington, D. C.:

The Civic Club of Washing ton, D. C., was organized about five years ago. As its name implies, its scope is eivic rather than charitable. Like all other organizations among the colored people of whatever kind. it has shown a lively interest in matters pertaining especially to the race. We have endeavored to oppose and remedy the discrimination that is shown in nearly all public places in this city against colored people. We have accomplished very little on account of the lack of suffrage. We have no building, but meet at the homes of members.

The Equal Suffrage League of the National Association of Colored Women has sent out literature and circulated petitions.

Section 23. Miscellaneous. Among miscellaneous efforts which may be noted are boys' clubs, summer camps, and efforts at securing work, humane bands and tuberenlosis leagues.

There is a Boys' Club in Indianapolis, Ind., and in Louisville, Ky., a society for the reclamation and improvement of newsboys.

The Boys' Culture Club of St. Paul, Minn., reports:

The Boys' Culture Club of St. Paul, Minn., was organized in January, 1904. The object of this club is to promote a feeling of brotherhood among its inember's, to teach them the principles of honest, intelligent self-government, to encourage good citizenship among them; also to be directed in Physical Cul- 
ture, that they may become strong, mental and physical men. During which time we have given several literary, gymnastic and athletic entertainments, among which we have given three annual, gymhastic and athletic expositions, in 19107, $190 \mathrm{~S}$ and 1909 , respectively.

We also have baseball, football and basket-ball teams in connection with the club. Each of the teams have made good records during the four years they have been playing. Neither team has lost more than two games out of the season.

The Wissahickon School Club, conducted by white people near Philadelphia for Negroes, has manual training class, out-door athletics, lectures and entertainments, and spends over $\$ 1,000$ a year; some 4,500 boys attend its various functions.

The Empty Stocking and Fresh Air School of Baltimore has a summer home for poor colored children.

The Summer Outing Home of Washington, D. C., maintains a camp of about 1500 children at a cost of $\$ 650$. This enterprise was supported by white and colored people.

The Woman's Employment Company of Indianapolis, Ind., maintains a Summer Camp for the sick, and the Lincoln Settlement of Brooklyn has summer outings.

In the line of increasing opportunities for employment there are numbers of benevolent efforts, among which might be mentioned the Farmer's Conference at Hampton and Tuskegee, the Georgia State College, Calboun and other places, and the Farmer's Union at Waugh, Ala.

There are two or three women's exchanges, one in Richmond, Va.

In New York and Philadelphia, through the Armstrong Association, there is a special effort to secure opportunities for competent Negro artisans to work; money and advice for this has been furnished by white and colored contributors. The actual work has been done by Negro executive officers. In Philadelphia, for instance, there was reported in 1908:

$$
\text { SUMMARY OF NINE MONTHS' WORK }
$$

Number of jobs given up to date since April, 1908 ....... 85

Number of men employed through such jobs............ 81

Amount of cash of such jobs, material and all, about.... $\$ 17,500$

Number of jobs estimated on since April, 1908, 1. e., over $\$ 500$ or in which there was a competitor, or in which an estimate was especially asked for by patron....... $\quad \$ 6$

Amount of cash in such, about..................... $\$ 133,000$

Jobs given to colored architects..................... 4

Number of meetings held by Carpenters' Association.... 20

Number of meetings held by General Association ....... 16

Manual training introduced in three public schools.

Public meetings held in churches.................... 4

The following is an outline of the work of the Armstrong Association for the colored people of Philadelphia from April, 1908, to January 1, 1909.

The chief work of the Association has been to secure work for competent colored mechanics, and thus to help them help themselves. Up to date nearly $\$ 18,000$ worth of work has been secured. More than 80 different 
men have thus been helped. The jobs ranged from 75 cents to $\$ 3,000$. As a direct result of the Association's activity, more colored mechanics are at work this winter than any winter before in this eity. For every dollar which has been spent by the Association for this branch of its activity, twenty dollars have come to the men whom it is designed to help. Among those from whom work has been secured are Mr. J.Henry Scattergood, Mr.John T. Emlen, Miss Ellen Morris, the Octavia Hill Association, the City of Philadelphia, Herman Voigt, Frank I. Wintz, contractors, and others. Many jobs have come from the colored people themselves. Opportunities to bid have been given by Savery, Scheetz \& Savery, Bailey \& Bassett and other architects.

The Association especially urges upon its patrons to assist in this feature of the work by permitting its mechanics to estimate on their work, thus helping the colored people to help themselves. The Association has as its members an ex-foreman on Panama canal work, a half dozen men who worked on the Rockefeller Hall, Bryn Mawr College, and on the Unirersity of Chicago, two foremen who worked on the well-equipped Rockefeller barn, Long Island; a former instructor in Tuskegee Institute, and another in Clark University; also graduates from various industrial schools, including Hampton and Tuskegee. Only first-class mechanies will be recommended.

Equally as good work has been accomplished by the Armstrong Association of New York.

There has been some effort to organize Humane Bands to teach children humanity in the care of animals, etc. In New Orleans, for instance, there are reported 47 such bands with 5,300 children connected with them.

Encouragement to buy homes is furnished in California by the Home Promoter's' Association.

The recent agitation about tuberculosis has resulted in a number of anti-tuberculosis societies.

There is an anti-tuberculosis league in Georgia with headquarters at Savannah, and one in Washington, D. C. :

Our society was organized November 11, 190s. A recent report of the Health Officer of this District contained such appalling figures with regard to the death-rate among colored people that in the eyes of many it amounted to an actual stigma on the race. In connection with many other obserring persons, howerer, Dr. Wilder considers this death-rate due not so much to constitutional weakness as to unhygienic housing, natural carelessness, and lack of sanitary information. This he proposed to remedy by the formation of a society to conduct an educational campaign among the people most in need of it. Necessarily our work is conducted mostly among colored people; more than 2.000 having been reached by lectures and house to house visits alone.

We hare also very pleasant relations with "The Society for the Prevention of Tubereulosis," some of its members haring visited our society during the progress of an entertainment and one of whom addressed us.

Our members are: first, honorars, which include all the pastors in the city who will accept membership, together with such men as Commissioner MeFarland, the late Dr, Reyburn and President Thirkield of Howard Lnirersity ; second, any one who will join. The names or the Board of Directors and Chairmanships show rou the class of persons who are doing the work.

We are supported by roluntary contributions and entertainments.

We give a pledge for framing and a neat little button to all who join. 


\section{Conclusion}

Section 24. Conclusion. From this general and very imperfect review of efforts for social betterment among Negro Americans it is slear that the evolution is in the right direction and that Colored people are more and more largely becoming interested in practical work for their own social uplift and are also to an increasing extent bearing the cost of this work. The most obvious criticisms and suggestions would be:

(1) A hope that the Negro church will in the future become more and more institutional and reformatory, and will call to its aid trained social workers. There are some small beginnings in this line already and they need encouragement.

(2) The economic foundation of the Negro school should be changed and changed quickly. To-day it rests partly on public aid, partly on the local efforts of Negro patrons, partly on general charity, and to a very small extent upon endowments. It should rest oll general local taxation, aided by grants of the National Government. Higher cultural and technical work should be supplied by National and State aid and endowments. This would free the benevolent public from the burden of Negro schools and also the Negro churches and organizations, and would enable the benevolence of black and white alike to be directed toward the pressing need of social reform in all the various lines indicated in this study.

(3) The work of women's clubs has been tremendous, both in its actual accomplishments and in its educational value. These clubs should be greatly multiplied and especially encouraged to take up local benevolent work.

(4) Old folk's homes, orphanages and hospitals are greatly needed. So far as possible orphanages should be made places of temporary detention only, and homes for the children obtained in good families. There is a pressing call for the spread of hospital work in country districts.

(5) The work of rescue among women and children especially and also among men and boys is greatly needed, particularly among city Negroes, and has been neglected too long.

(6) In the direction of art and literature much can be done which has not been done for Negroes. It is difficult for the people of America to understand that the Negro is essentially an artistic being, whose rich emotional nature can be made to contribute much to the world's enjoyment and appreciation of beauty. 'To this'end greater opportunity in drawing and music and other art-training should be opened to Negro children.

(7) Day nurseries, social settlements and kindergartens, together with other of the newer forms of uplift work, like public play-grounds, should be furnished for the right training of the black workingman's children to a much larger extent than now. In fact, in these lines, only the beginnings of work can be noted.

(8) While something can be accomplished by organizations for civic reform among Negroes themselves, jet so long as the race is deprived of the ballot it is impossible to make such organizations of the highest efficiency in any avenue of life, whether it be education, religion, work, or social reform; the inpossibility of the Negro accomplishing the best work so long as he is kept in political serfdom is manifest even to the casual student.

There would seem to be for the philanthropists no more inviting' field for work than in helping on some of the efforts for social 1 plift which Negroes have instituted and are carrying on. 


\section{Efforts for Social Betterment among Negro Americans}

\section{Index}

Afro $=$ American Council................. 36

Afro-American League ............... $\$ 6$

Alabama ...........................

$32,43,49.55,56,61,62,72,73,117,118,121,131$

American Baptist Home Mission Society........................ 85

American Economic Association.. 12, 16

A. M. E. Church ............... 25, 26

A. M. E. Missionary Department... 18, 19

A. M. E. Zion Church .............. 27

American Negro Academy....... 35, 108

Anti-tuberculosis leagues........... 132

Arkansas .................... 52, 74

Armstiong Association .......... 131, 132

Art and literature ................ 139

Assessed value Negro property in

three States (chart) ........... 15, 16

Associated Char ities ............... 126

Atlanta Baptist College .............. 31

Atlanta, Ga., kindergartens ......... 126

Atlanta Negro Conference ........... 36

Atlanta University........... 5, 6, 31, 32

Authors, Negro............. 109, 110,111

Baptists in Arkansas ............... 22

Baptist Women's Missionary Convention.............................. 25

Baptist Young People's Union........ 21

Barnet, Mrs. Ida B. Wells ........... 55

Benefactions to Negio schools ....... 35

Benerolence..... 27, 28, 42, 43, 44, 45, 46,47

Bethel Church, Philadelphia......... 26

Bibliography . ................... 7,8

Board of Education of English gorernment ....................... 6

Brunswick county, Virginia......... 32

Bureau of Education ............... 35

California............... 43, 46, 49, 55, 103

Cape Town........................ 26

Calnegie Institution ................6 6

Cash paid by Negro students.......... 34

Charity ...................... $42 \cdot 47$
Oha.rt of Negro churches............. 17

Ohurch, The Negro........ 16, 109, 110, 133

Ohurches ........................... 28

City Young Men's Chlistian Associa-

tions . . . . . . . . . . . . . . 96,97

Civic reform ......... 127, 128, 129, 130, 133

Clark University .................... 31

Clubs, Boys'................... 130, 131

Clubs, Men's .................... 105, 106

Clubs, Miscellaneous ........... 130, 131

Clubs, Women's ............ 42, 47-64, 183

Coleridge-Taylor Choral Society...106, 107

Coleridge-Taylor, Samuel....... 106, 107

Oolorado..................... 49,51, 52

Colored Boys' Reformatory .......... 32

Oolored Women's Ohristian Association ........................... 26

Colored Young Men's Christian Asso-

clations by States............... 96

Committee of Twelve, The........... 35

Communism among Africans ........ 10

Conference for Education in the South 29

Connecticut ....................45, 65

Constitution League, The ........... 36

Contributions of Negro Baptists to education ..................... 30

Contributions of Negro M. E. member's to education ................. 30

Coon, Chas. L..................... 29

Co-operative Education Commission, The .......................... 30

Criminality among Negroes........ 127

Deaconess work.................... 26

Dispensaries ..................... 98, 95

District of Columbia................ $.5,26,37,44,48,69,87,103,120,122,123,132$ Donations of colored people.......... 33 Donors, Negro..................... 42 Douglass Center, Frederick.... ...... 122 Douglass, Frederick................ 56

Duncan, Miss Anna M............ 57 
Efforts, Miscellaneous.............. 130

Enterprises, Negro................ 12

Equal Suffrage League............. 130

Equiano, Olaudah................. 109

Expenditures for Baptist missions. 19, 20

Expenditures for schools............ 34

Farmers' Conference ............. 32, 131

Federations, State................. 49

Fisk University . .............. 80,32

Flanner Guild, Indianapolis .... 124, 125

Florida .............. 49, 55, 56, 72, 125

Foreign Scholarship Association.... 107

Forum, The, Paducah, Ky .......... 130

Freedman's Bureau, The............ 34

Freedmen's Hospital, The........... 87

Funds, Negro church............. 18

Georgia........ 14, 28, 29, 49, 56, 57, 58, $72,77,78,81,82,83,84,86,88,89,90,129,132$

Hale Infirmary .................... 57

Hampton Institute................ 31

Hampton Negro Conference......... 36

Hand fund, Daniel.................. 35

Haygood, Dr. A. G................ 34

History, Negro................... 110

Home for the Aged ...............61

Home for Working Girls........ 56, 61

Home Mission Board .............. 20

Hospitals..... 87, 88, 89, $90,91,92,93,94,95$

Howard University ................. 5

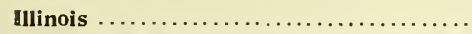

$\ldots 45,48,49,51,60,61,75,79,80,81,122,129$

Income of Atlanta University....... 33 Indiana $\ldots \ldots \ldots \ldots \ldots \ldots 32,36,46,49,58,61$ Institutional Church, Atlanta....... 125 Iowa .................... 49, 77

Jackson County Home for Negro girls... 103 Juvenile courts............... 127, 128 Juvenile work .................... 26

Kansas $\ldots \ldots \ldots \ldots \ldots \ldots \ldots \ldots \ldots \ldots, 48,49$ Kemble, Frances.............. 10, 11 Kentucky........47,49, 58, 74, 94, 120, 121 Kindergartens ................ 126, 127

Lafon, Thomy................ 40, 41, 85 Law and Order leagues......... 128, 129 Lecture bureaus.................. 105
Lee, Jarena........................ 22

Libraries .................... 117, 118

Libraries, Traveling ............... 119

Library, Public............... 118, 119

Lincoln Sattlement, Brooklyn....... 124

Literary societies ............. 104, 105

Literature and newspapers....... 109-117

Louisiana.............. 48, 73, 77, 85

Macon county, Ala.................. 38

Magazines ........................ 116

Maine ............................. 58

Maryland ......................... 49

Mason, Primus Parsons......... 38, 39,66

Massachusetts....... 46, 48, 56, 59, 61, 66

McKee, Dolonel John .............. 88

Meeiings, Mothers'................ 26

Method of the study ................ 9

M. E. Ohurch ................. 30,35

Michigan..........4 45, 48, 49, 59, 76, 102

Minnesota ............... 49, 50,51, 60

Miscellaneous general efforts ........ 85

Missionaries, African .............. 27

Mississippi ............... 49, 53, 59, 92

Missouri........ 28, 48, 49, 54, 55, 61, 74, 75

Money, Mission, raised by Baptists in Texas ........................ 21

Mosely, John..................... 37

Music, Negro.................... 111

\section{National Association of Colored Women}

.......................47, 48, 180

National Association for Protection

of Colored Women... ........... 102

National Baptist Publishing Board... 20

National Negro Conference.......... 36

National Political League............ 35

Negro Business League............. 35

Negroes and Christian Associations 95, 96

New Jersey .................. 59, 60, 88

Newspapers, Negro.... 113, 114, 115, 116, 117

New York. . 45, 48, 55, 56, 77, 87, 121, 122, 132

Niagara Movement................ 35

North Garolina ..... 28, 29, 36, 37, 71, 72, 78

Nurseries, Day.......... 26, 119, 120, 139

Object of Atlanta University studies.... 5 Ohio.......... 49, 61, 76, 86, 96, 104, 120, 126 Oklahoma ....................... 118

Old Folk's Homes..................

$65,66,67,68,69,70,71,72,73,74,75,76,77,133$ Orphanages......................

$\ldots \ldots \ldots 77,78,79,80,81,82,83,84,85,86,87$ Ownership of schoolhouses........... 30 
Payne, Bishop ..................... 25

Peabody fund ...................... 35

Penn school....................... 31

Pennsylvania ................... 36, 49

$60,77,91,92,94,119,120,123,127,131,132$

Philanthropists, Negro. $37,38,39,40,41,42$

Pitchford, Naney................. 38

Presbyterian colored missions....... 121

Probation officers................ 127

Property of Georgia Negroes (chart).. 14

Property owned by Negroes ....... 12, 13

Provident Hospital............ 92, 93, 94

Rachel, Joseph .................... 37

Reed Home................. 82, 83, 84

Reformatories............. $32,57,129$

Reformatory Association, Richmond,

Va.......................... 129

Refuges and Rescue Homes for

Women ............. 100, 101, 102, 103

Religious opinions................. 29

Reports, Missionary........ 23, 24, 25, 26

Report, Ninth Annual, of Baptist

Woman's Conrention ............ 23

Rescue work .................... 133

Rhode Island. ................... 60

Ruffin, Mrs. Josephine St. Pierre..... 47

Rural school fund, Negro............ 35

Saint Cyprian's Chapel........... 121, 122

School Improvement leagues....... 30, 31

Schools, Negro... 29, 30, 31, 32, 33, 34, 35, 133 Scope of the study.................. 9

Secret and insurance societies....... $30^{\circ}$ Self-help in Negro education.... 29, 30, 31 Shorter, Bishop................... 25 Slater, John F., fund .......... 5, 6, 31, 35 Slavery ....................... 10, 11 Slares, Georgla ...................... 11 Smith, Mrs. Amanda............... 79 Smith, Stephen ................... 42 South Carolina...... 48, 72, 79, 84, 88, 90, 91 Social, Literary and Art Clubs...

$104,10 \overline{2}, 106,107,108$ Social settlements. .121, 122, 123, 124, 125, 126 Social work ..................... 31
Spring Street Settlement, Philadelphia ..................... 123, 124

Starr Center, Philadelphia......... 123

Statistics of Negro churches .. ..... 16

Stokes fund ...................... 35

Student Young Men's Ohristian Associations................... 97, 98

Students, Negro .................. 30

Support, Financial . ................6 6

Talladega College.................... 57 Teachers' Associations ........... 32, 33 Temperance................ 26, 63, 127 Tennessee.................48, 49, 60, 74 Texas.......... 28, 36, 43, 49, 54, 87, 88, 92 'Texas State Baptist conrention...... 21

Thoumazeau, Jasmin............... 37 Tubman, Harriet, House, Boston . . 101, 102 Tuskegee Negro Conference.......... 36

U. S. Bureau of Labor $\ldots \ldots \ldots \ldots \ldots \ldots, 6$

U. S. Census .....................6 6

Virginia $\ldots \ldots \ldots \ldots \ldots \ldots \ldots \ldots 28,29,30,31$ $32,43,46,49,51,78,81,82,125,126,130,131$

Washington, George............. 39, 40

West Virginia ..................... 49

Wheatley, Phyllis................. 109

Wheatley, Phyllis, Home of Chicago 100

White, Sarah Ann................. 68

Woman's Home and Foreign Missionary Society............... 27

Woman's Parent Mite Missionary

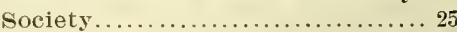

Wright, R. R., Jr. ............. 29, 30

Wyoming...................... 52

Young Colored Women's Protective Association, Indianapolis ...... 100, 101 Young Men's Ohristian Association. 31, 95, 96, 97, 98, 99

Young Women's Christian Association ............47, 95, 96, 97, 98, 99 


\section{STUDIES OF ¿RO PROBLEMS}

\section{The Atlanta L uversity Publications}

\section{COPIES FOR SALE}

No. 1. Mcrtality among Negroes in Cities; 51 pp., 1896 . Out of print.

Mortality among Negroes in Cities; 24 pp., (2nd edition, abridged, 1903). 169 copies at $25 \mathrm{c}$.

No. 2. Sc cial and Physical Condition of Negroes in Cities; 86 pp., 1897. 823 copies at $25 \mathrm{c}$.

No. 3. Some Efforts of Negroes for Social Betterment; 66 pp., 1898. Out of print.

No. 4. The Negro in Business; 78 pp., 1899. Out of print.

No. 5. The College-bred Negru; 115 pp., 1900. Out of print.

Th, College-bred Negru; 32 pp., (2nd edition, abridged). , 500 copies at $25 \mathrm{c}$.

No. 6. The Negro Common School; 120 pp., 1901. Out of print.

No: 7. The Negro Artisan; 200 pp., 1902. 590 copies at $75 \mathrm{c}$.

No. egr $\quad$ h, 212 pp., 1903. 292 copies at $\$ 1.00$.

No.

75 pp., 1904. 1, 141 copies at $50 c$.

No.

of the Negro American; 72 pp., at $25 \mathrm{c}$.

No. 1

ff the Negro American; $112 \mathrm{pp}$., $t \$ 1.00$.

No.

among Negro Americans; 184 pp., at $\$ 1.00$.

amily; 152 pp., 1908. 1,500 copies

rment among Negro Americans; copies at $75 \mathrm{c}$. 


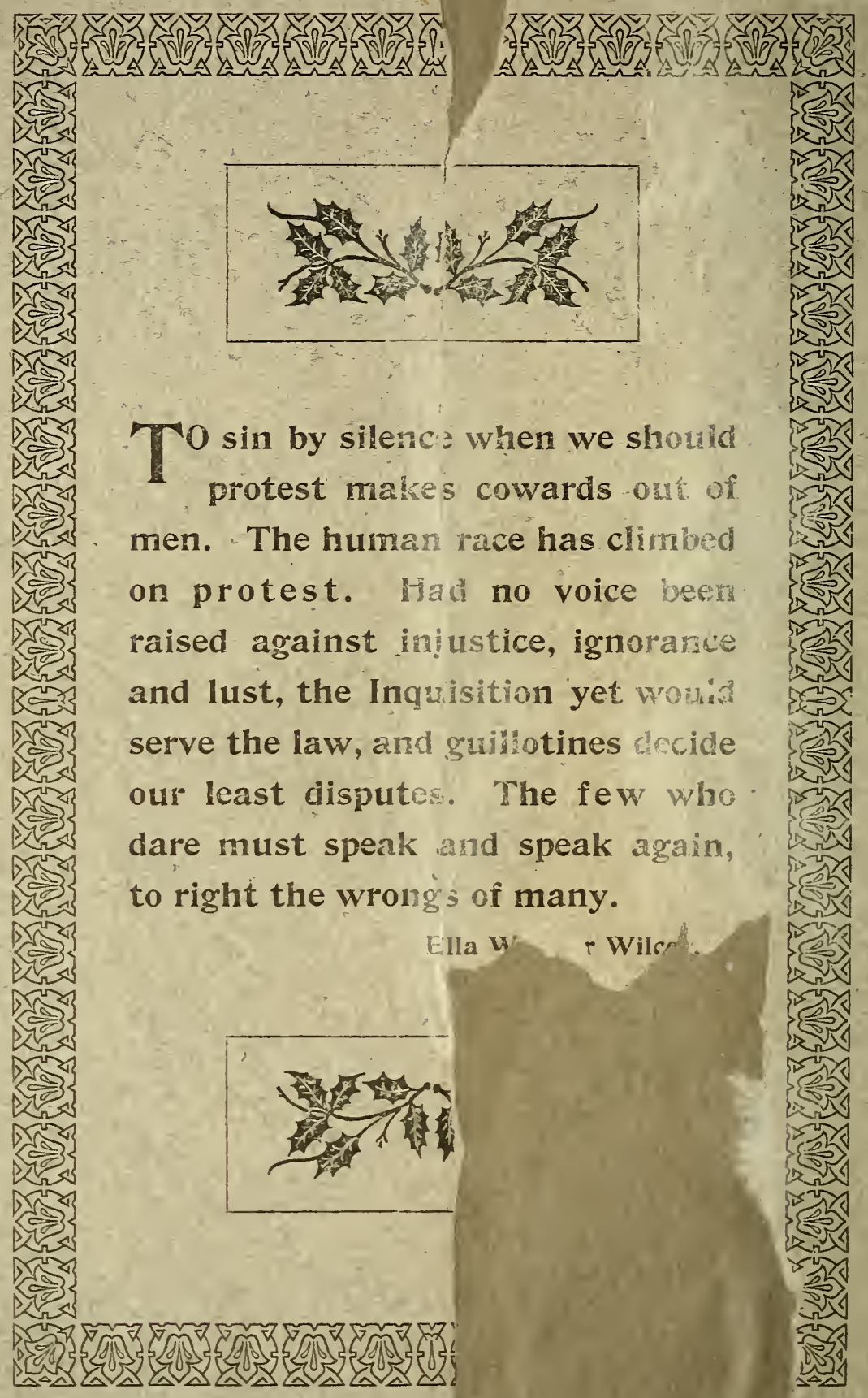











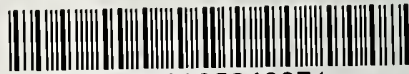 39088005943071}

